\title{
A TALAJ-NÖVÉNY-LÉGKÖR RENDSZER MODELLEZÉSÉNEK LÉPTÉKFÜGGŐ PROBLÉMÁI
}

A léptékfüggés a talaj vízgazdálkodási tulajdonságaiban, valamint a megfigyelt hőmérsékleti adatsorokban

Ph.D. értekezés

SÁNDOR RENÁTA

Témavezető: Dr. Fodor Nándor

Belső konzulens: Prof. Dr. Sümegi Pál

Szegedi Tudományegyetem

Környezettudományi Doktori Iskola

Szeged, 2014 


\section{TARTALOMJEGYZÉK}

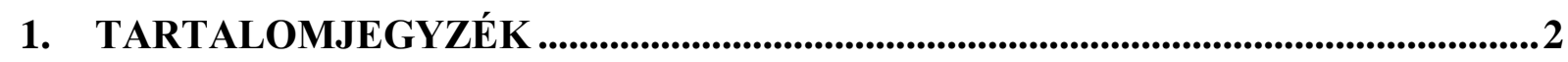

2. RÖVIDÍTÉSEK JEGYZÉKE ..................................................................................6

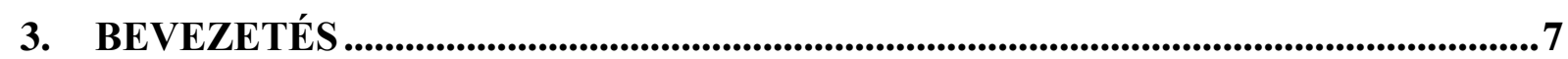

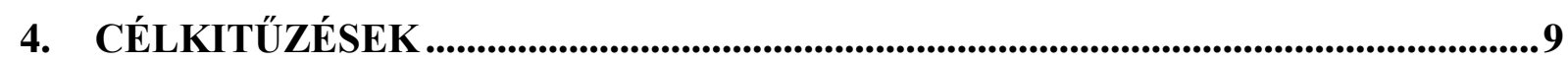

5. IRODALMI ÁTTEKINTÉS és ELMÉLETI HÁTTÉR ................................................10

5.1. TALAJ-NÖVÉNY-LÉGKÖR RENDSZER MODELLEZÉSE..................................10

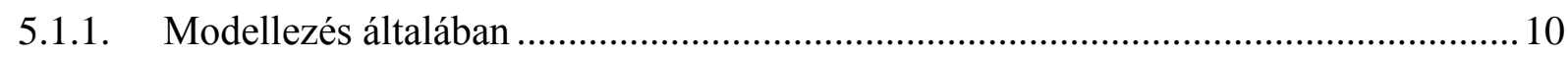

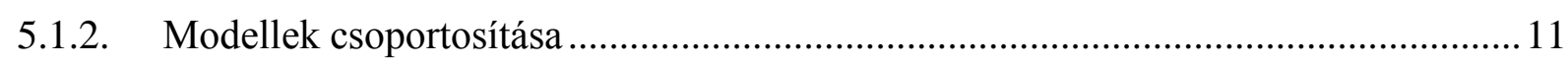

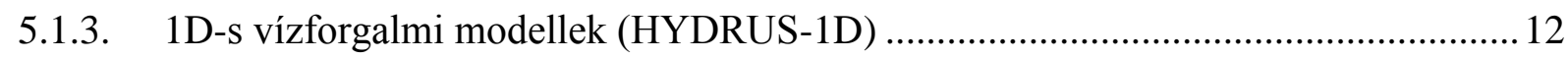

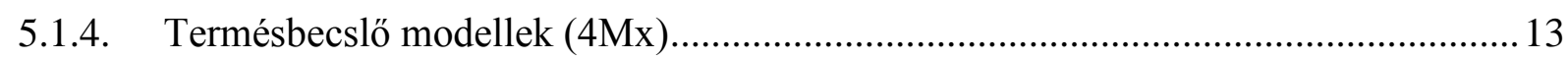

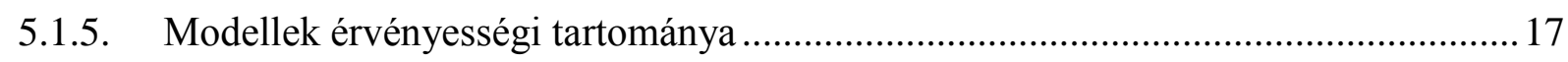

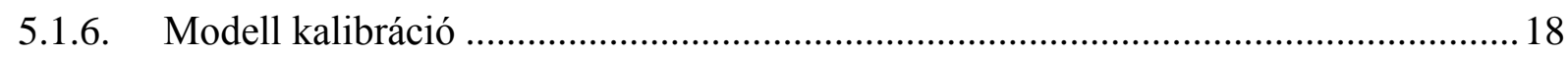

5.2. MÉRÉSBŐL és MODELLEZÉSBÖL ADÓDÓ LÉPTÉKFÜGGÉS ……………......18

5.2.1. A léptékfüggés meghatározása ............................................................................... 19

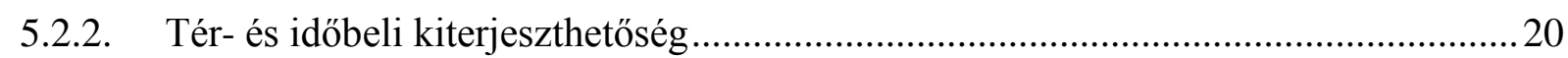

5.2.3. A meteorológiai adatok szerepe a modellekben.........................................................21

5.2.3.1. Hömérséklet....................................................................................................21

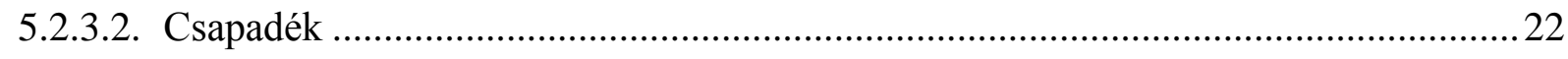

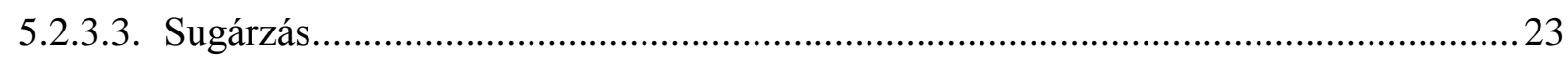

5.2.4. A meteorológiai adatok léptékfüggése ...................................................................2

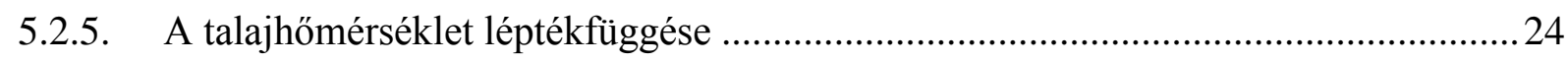

5.2.6. A talaj nedvességforgalmát meghatározó modell-paraméterek ………………….....25

5.2.7. A nedvességforgalmat jellemzö paraméterek és adatok léptékfüggése .....................26

5.2.8. A telítési vízvezetö képesség meghatározása ……………………………………......27

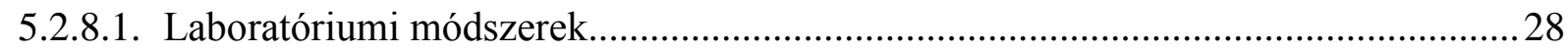

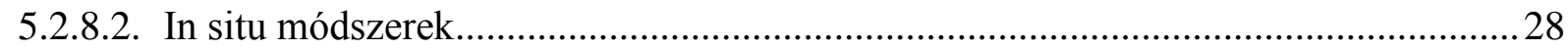

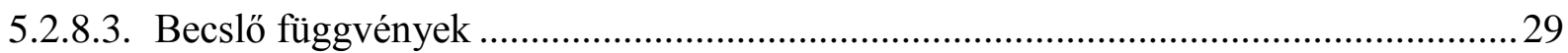


5.2.9. A telítési vízvezető képesség mérés léptékfüggése .............................................29

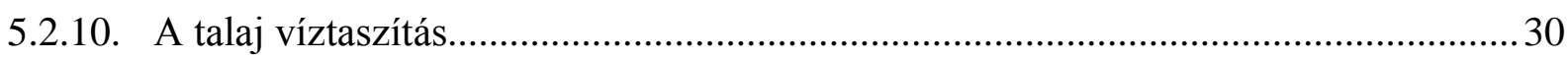

5.2.11. Léptékfüggő problémák kezelése átlagolással .................................................. 31

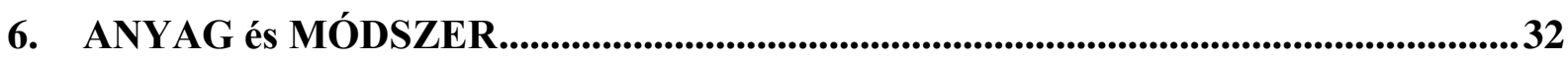

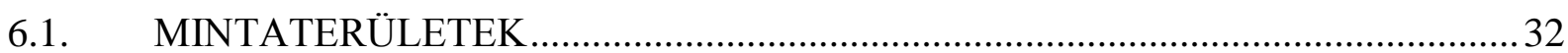

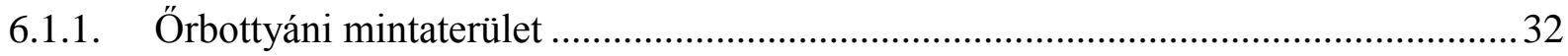

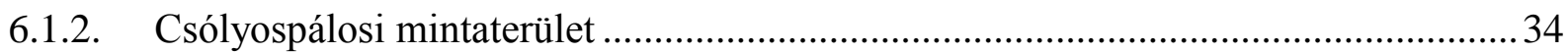

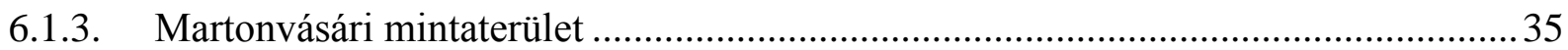

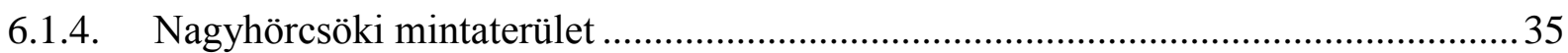

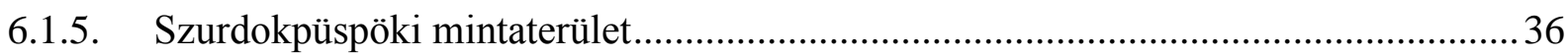

6.2. A VIZSGÁLT RENDSZERVÁLTOZÓK MEGHATÁROZÁSA .............................36

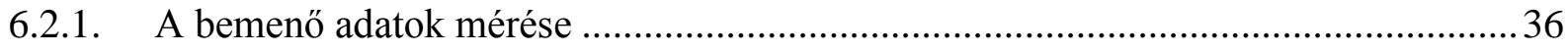

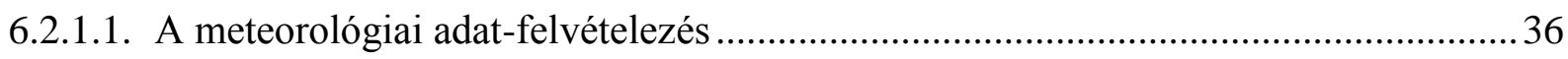

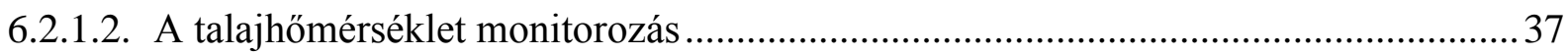

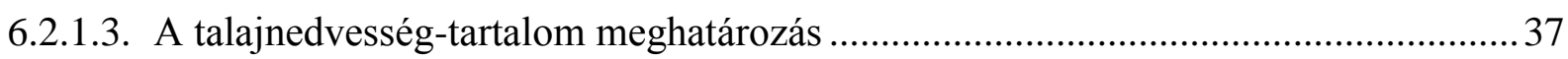

6.2.1.4. A növényi bemenő adatok meghatározása ......................................................... 37

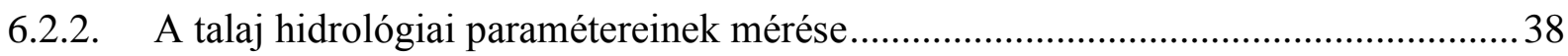

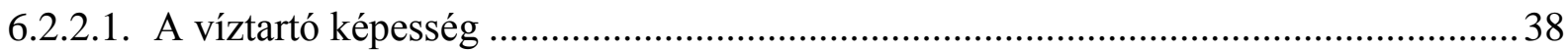

6.2.2.2. A telítési vízvezető képesség meghatározása ........................................................ 38

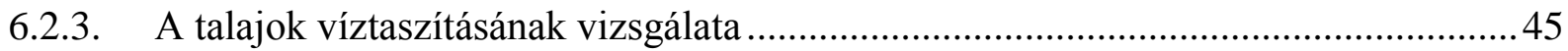

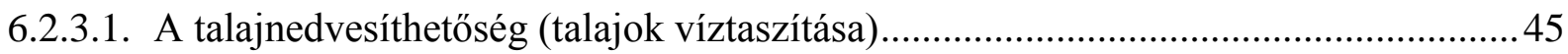

6.2.3.2. A talajok szervesanyagának és humuszfrakcióinak meghatározása.......................... 46

6.3. HIDRAULIKUS TULAJDONSÁGOK IDÖ-, és TÉRBELI LÉPTÉKFÜGGÖ

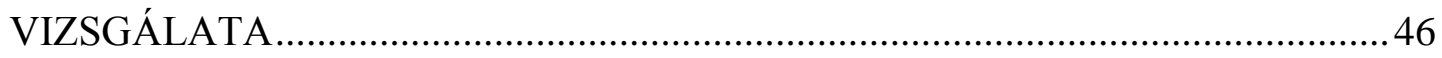

6.3.1. A telítési vízvezető képesség időbeli változása....................................................... 46

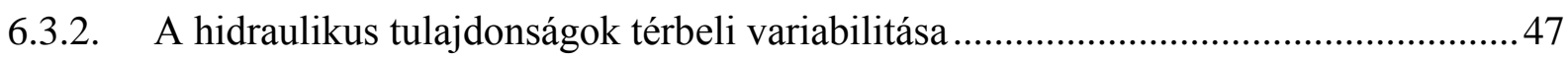

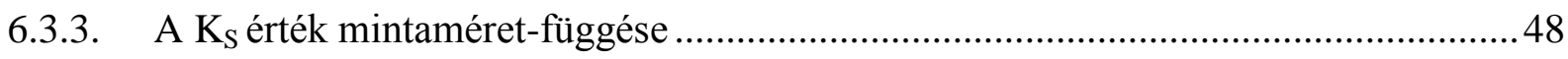


6.4. A LÉPTÉKFÜGGÉS MEGJELENÉSE a 4Mx és HYDRUS-1D MODELLEK

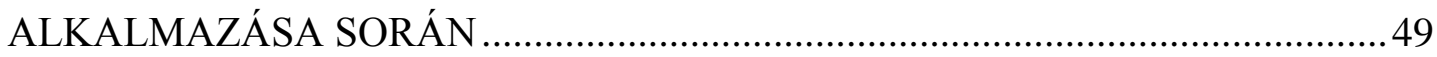

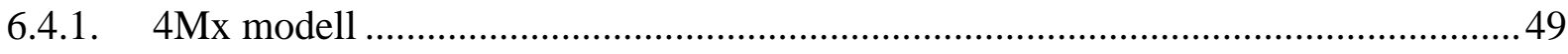

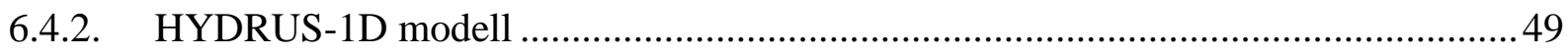

6.4.3. A léptékfüggés megjelenése a meteorológiai adatsorok felhasználásakor.................51

6.4.4. Eltérő térléptékü modellekkel számított talajhőmérséklet értékek összehasonlítása .52

6.4.5. Mért és szimulált talajnedvesség értékek összehasonlítása, növénytermesztési kísérlet

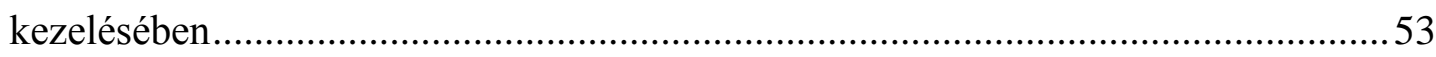

6.4.6. Beszivárgás és talajpárolgás modellezésének térbeli léptékfüggése .........................54

6.4.7. A térbeli heterogenitás következtében előálló modellezési problémák különböző

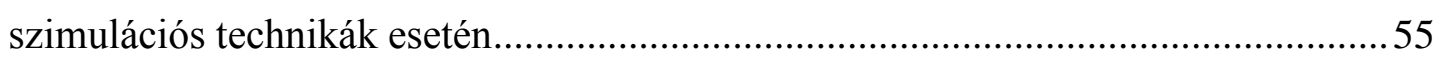

7. EREDMÉNYEK és KÖVETKEZTETÉSEK_...........................................................56

7.1. A VIZSGÁLT TALAJOK HIDROLÓGIAI PARAMÉTEREI ................................56

7.2. HIDRAULIKUS TUALJDONSÁGOK IDÖ-, és TÉRBELI LÉPTÉKFÜGGÖ

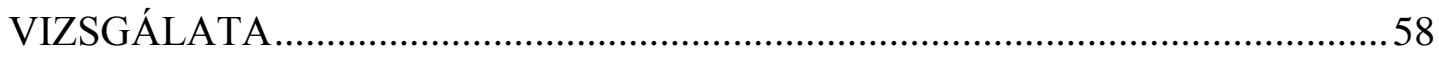

7.2.1. A telítési vízvezető képesség időbeli változása....................................................58

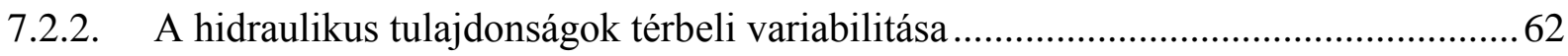

7.2.2.1. A talajok víztaszítás értékének térbeli változatossága ..........................................62

7.2.2.2. A telítési vízvezető képesség térbeli változatossága ............................................... 65

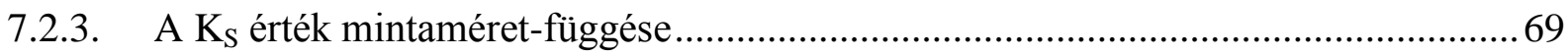

7.3. A 4Mx és a HYDRUS-1D MATEMATIKAI MODELLEK ALKALMAZÁSA......71

7.3.1. A léptékfüggés megjelenése a meteorológiai adatsorok felhasználásakor.................71

7.3.2. Eltérő térléptékü modellekkel számított talajhőmérséklet értékek össze-hasonlítása 73

7.3.3. Mért és szimulált talajnedvesség értékek összehasonlítása növénytermesztési kísérlet

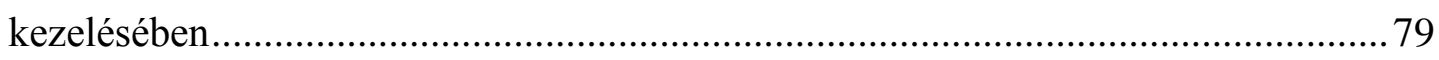

7.3.4. Beszivárgás és talajpárolgás modellezésének térbeli léptékfüggése ......................... 83

7.3.5. A térbeli heterogenitás következtében előálló modellezési problémák különböző

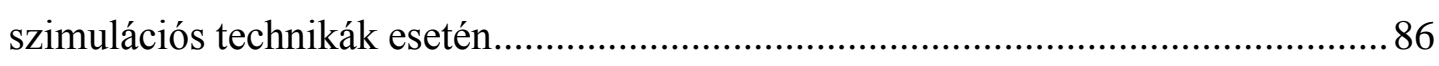

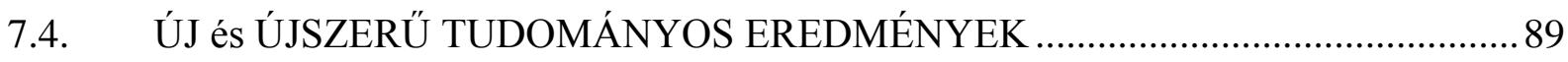




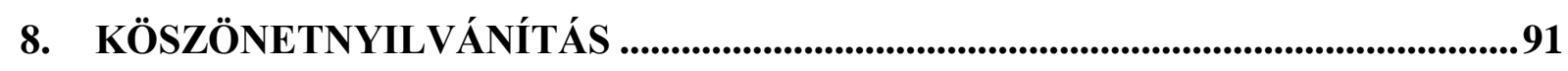

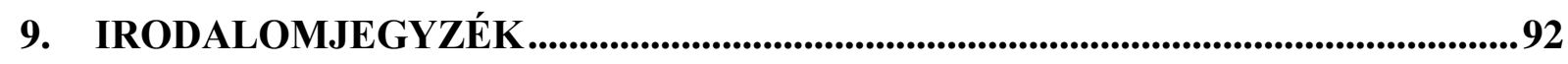

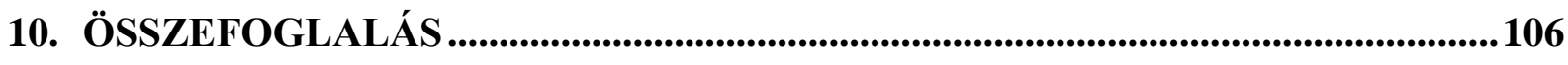

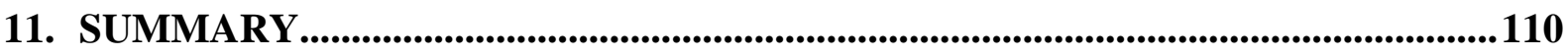

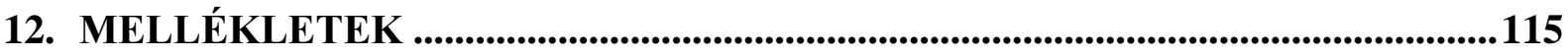




\section{RÖVIDÍTÉSEK JEGYZÉKE}

$\alpha$ és n: a van Genuchten-féle víztartóképesség-függvény együtthatói

AE: Average Error, átlagos hiba

FA: fulvo acid, fulvo sav [\%]

HA: humic acid, humin sav [\%]

Hu: humus, szerves anyag [\%]

h: nedvességpotenciál $[\mathrm{m}]$

$\mathrm{K}_{\mathrm{fs}}$ : telítésközeli vízvezető képesség $\left[\mathrm{ms}^{-1}\right]$

$\mathrm{K}_{\mathrm{S}}$ : telítési vízvezető képesség $\left[\mathrm{ms}^{-1}\right]$

$\mathrm{K}(\mathrm{h})$ : vízvezetőképesség-függvény $\left[\mathrm{ms}^{-1}\right]$

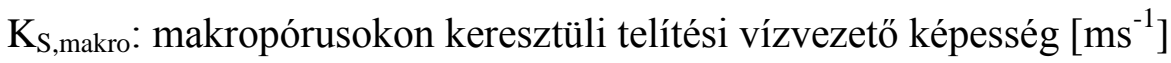

$\mathrm{K}_{\mathrm{S} \text {,matrix }}$ : talajmátrix telítési vízvezető képesség $\left[\mathrm{ms}^{-1}\right]$

LAI: levél felület index []

MDI: Mini Disk Infiltrométer

PTF: pedotranszfer függvény

$\mathrm{R}^{2}$ : determinációs együttható

RMSE: Root Mean Squared Error, átlagos négyzetes hiba négyzetgyöke

S: relatív telítettség [\%]

$\Theta$ : talajnedvesség-tartalom $\left[\mathrm{m}^{3} \mathrm{~m}^{-3}\right]$

$\Theta_{\mathrm{fc}}$ : szabadföldi vízkapacitás $\left[\mathrm{m}^{3} \mathrm{~m}^{-3}\right]$

$\Theta_{\max }$ : maximális vízkapacitás $\left[\mathrm{m}^{3} \mathrm{~m}^{-3}\right]$

$\Theta_{\mathrm{wp}}$ : hervadás ponti vízkapacitás $\left[\mathrm{m}^{3} \mathrm{~m}^{-3}\right]$

t: idő [s]

$\mathrm{T}$ : hőmérséklet $\left[{ }^{\circ} \mathrm{C}\right]$

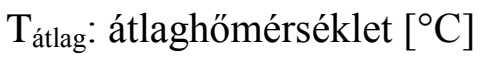

$\mathrm{T}_{\text {bázis: }}$ : bázishőmérséklet $\left[{ }^{\circ} \mathrm{C}\right]$

TDI: Tension Disc Infiltrométer

TDR: Time Domain Reflectometry talajnedvesség mérési módszer

WDPT: Water Drop Penetration Time, vízcsepp beszivárgási idő 


\section{BEVEZETÉS}

A talaj-növény-légkör rendszer folyamatai és jelenségei túlságosan összetettek ahhoz, hogy egyszerre minden részletükben vizsgálhatók és elemezhetők legyenek. Mérésekkel is vizsgálhatunk bonyolult rendszereket, melyek eredményeit különböző statisztikai módszerekkel (pl. varianciaanalízissel) értékelhetjük. Azonban a legkomplexebb összefüggések együttes vizsgálatára és a rendszer müködésének leírására a matematikai modellek a legalkalmasabbak, de a mérést nem helyettesítik. A valós rendszer komponensein belül a legmeghatározóbb folyamatokat kiemelve és leegyszerüsítve különböző modellekbe, azokon belül pedig modulokba foglalhatjuk (Szász és Tőkei, 1997; Huzsvai et al., 2005). A modellezés során az a célunk, hogy a vizsgált terület egyes jellemző tulajdonságait felhasználva a megfigyelt fizikai valósághoz müködésében hasonló rendszert hozzunk létre. Ezért a modell és a modellezett rendszer szempontjából fontos megadni, hogy mely tényezőket, folyamatokat, illetve szempontokat vesszük figyelembe és azok milyen mérettartományon belül érvényesek, továbbá, hogy az alkalmazott modellünk milyen léptékben müködik (Rajkai, 2001).

Egy valós rendszer valamely tulajdonságának léptéke az a felbontást, amely részletességgel területi, illetve időbeli változatosságát, változékonyságát jellemezzük. A léptékfüggés problémája azért merül fel, mert a megfigyelt valós rendszer, valamely tulajdonsága változatos és/vagy változékony. A térbeli változatosságot, illetve időbeli változékonyságot többváltozós differenciálegyenlet-rendszerrel, írhatjuk el, de ezek megoldása sok esetben körülményes és időigényes feladat. Ezért születtek olyan modellezési megoldások, melyek az időben változó dinamikájú folyamatokat rövid, kvázi-stacionárius elemekre bontják, azaz a folytonos valóságot diszkrét szakaszok sorozataként kezelik. Továbbá, a folyamatok szimulálása során a modellek egy-egy homogénnek feltételezett területre vonatkozóan végzik számításaikat, különböző léptékben (pl.: pedon, polipedon, vízgyüjtő, kontinens, világ) (Rajkai, 2001; Huzsvai et al., 2005). A modellek diszkrétek, következésképpen léptékfüggőek. Mivel a modellek a tér- és időbeli lépésközön belüli változásokat nem veszik figyelembe (átlag értékkel számolnak), ezért a számítások eredménye eltérő lehet attól függően, hogy milyen tér- és időbeli lépésközt alkalmaznak. Egy adott folyamatot leíró modell is mindig csak egy meghatározott léptékre lehet érvényes, ezért a modell kiválasztásánál a modellezendő folyamat léptéke, érvényességi tartománya meghatározó (Rajkai, 2001). Például a 4Mx agrometeorológiai modell dm-es egységekre bontja fel a talajprofilt (Fodor et al., 2001), míg a HYDRUS-1D hidrológiai modell cm-es felbontást alkalmaz (Šimůnek et al., 1998). Ezért felmerül a kérdés, hogy a felbontás 
finomításával milyen léptékfüggésböl eredö különbség jelentkezhet a modell eredményekben. A fentiek következtében a validálás léptékétől eltérö léptékben nem ajánlott használni az adott modellt (Huzsvai et al., 2005), mivel a léptékkel nem csupán a modellezendő terület fizikai mérete változik, hanem a folyamatok kinetikája is. Egyértelmü például, hogy a molekuláris lépték folyamatainak időtartama nem lehet azonos a pedon szinten végbemenő történésekével.

A modellezőknek mért adatokra (pl.: paraméterértékekre, határfeltételekre) van szükségük ahhoz, hogy minél pontosabban le tudják írni a valós rendszert. Az adatok azért kellenek, hogy a folyamatokat leíró összefüggések paramétereit egy adott területre, illetve az adott feltételekhez illeszthessük. Azonban magának a mérésnek is van egyfajta léptékfüggése, mivel nem folyamatos, hanem bizonyos időegységenként történik, illetve a méréseket a vizsgált objektum egyes pontjaiban végezzük, így méréseink is diszkrétek. Talajok megfigyelésekor felmerülhet bennünk a következő kérdés: A bizonyos pontokban és bizonyos időközönként felvételezett értékekkel valósághü képet kapunk-e a vizsgált objektumról, illetve annak változásáról? Amennyiben egy általunk vizsgált talajtulajdonság mérésére az optimálisnál finomabb, vagy durvább léptéket választunk, a vizsgált talaj viselkedését eltérő módon észlelhetjük, mint a megfelelö lépésköz (térbeli és/vagy időbeli) alkalmazása esetén. További problémát vet fel, hogy a mérőmüszernek is van kiterjedése, ebből kifolyólag nem egy pontra vonatkozó, hanem egy terület, vagy térfogatelemre érvényes átlagértéket mérünk. Ugyanazt a rendszerváltozót (pl. hidraulikus vezetőképesség) viszont különböző kiterjedésű eszközökkel is meg tudjuk mérni, így felmerül a kérdés, hogy az eszköz méretétől függ-e a mért érték? Annak függvényében, hogy a bemenő adatokat milyen módszerrel mérjük, milyen a mérőmüszerünk felbontása és pontossága, és milyen időközönként történik az adatrögzítés, még a modellezés elött jelentős hibával terhelhetjük az eredményünket. A modell a mérési hibát változatlanul átviheti, esetleg növelheti, vagy csökkentheti.

Modellezés-technikai szempontból fontos, ha a vizsgált területre vonatkozóan több adattal rendelkezünk, akkor milyen módszer szerint értékeljük ki azokat. Például lényeges különbség adódhat abból, hogy a mért értékeket a modellezést megelőzően, vagy azt követően átlagoljuk (Stein et al., 1991; Bechini et al., 2000).

Amennyiben a térben és időben folytonosan változó jellemzőt diszkrét módszerekkel vizsgáljuk, (mérjük és modellezzük) a vizsgálati eredményeknek óhatatlanul léptékfüggése lesz, mely nagymértékben befolyásolhatja a modell kimeneti értékeit (Rao et al, 1977; Addiscott és Wagenet, 1985a). Ezért fontos a talaj-növény-légkör rendszer modellezéséhez kapcsolódó problémák léptékfüggésének vizsgálata és meghatározása. Ennek megfelelően a doktori dolgozatom célkitüzéseit a 4. fejezetben fogalmaztam meg. 


\section{CÉLKITÜZÉSEK}

A munkám célja a talaj-növény-légkör rendszermodellek meghatározó folyamatinak áttekintése valamint a felmerülő léptékfüggő problémák vizsgálata a következő részfeladatok sorozataként:

1. Befolyásolja-e a telítési vízvezető képesség értékét, és ha igen mekkora mértékben, a vizsgált minta mérete?

2. Milyen típusú változások jellemzik müvelést követően a telítési vízvezető képesség értékét homok és vályog fizikai féleségű talajokon?

3. Van-e pedon léptéken belüli változatossága a telítési vízvezető képesség és víztaszítás értékeknek homoktalajon illetve mi okozhatja annak víztaszítását?

4. Van-e különbség a mért és az eltérö léptékben szimulált talajhőmérséklet és talajnedvesség értékek között a növény- és hóborítottság függvényében?

5. Befolyásolja-e a szimulált beszivárgás és talajpárolgás értékét a modellben alkalmazott szelvényfelbontás, továbbá a szimulált növényi fejlödést a meteorológiai adatok felvételezési gyakorisága?

6. Van-e különbség a szimulált talajnedvesség eredményekben annak függvényében, hogy a több ismétlésben mért bemenő adatokat a modell szimulációt megelőzően átlagoljuk, vagy a különböző bemenő adatokkal kapott eredményeket a szimulációt követően átlagoljuk? 


\section{IRODALMI ÁTTEKINTÉS éS ELMÉLETI HÁTTÉR}

A talaj-növény-légkör rendszer komponensein belül és a komponensek között anyag- és energiaáramlás megy végbe. A talaj komponensen belül az anyagforgalomnak igen jelentős és meghatározó részét képezik a talajban lejátszódó fizikai folyamatok. Hasonló fontossággal bírnak a növényi anyagcsere- és transzportfolyamatok, melyek meghatározzák a növényi növekedést, $\mathrm{s}$ ezáltal a várható termés mennyiségét. A légkör közvetlenül és közvetve is kifejti hatását a talaj-növény rendszer folyamataira. A légköri és a talaj-növény rendszerben végbemenő folyamatok összetettsége miatt azok vizsgálatára a matematikai modellezés az egyik legalkalmasabb eszköz, a fizikai, képi vagy verbális leírás mellett. A modellezés során a vizsgált objektum leglényegesebb tulajdonságait használjuk fel, hogy a valóságoshoz hasonló rendszert hozzunk létre. A modell és a modellezett rendszer szempontjából fontos megadni, hogy mely tényezőket, folyamatokat, illetve szempontokat veszünk figyelembe, és ezek milyen léptékben érvényesek. A modellparaméterek és bemenő adatok időbeli variabilitása és térbeli heterogenitása nagymértékben befolyásolja a modell kimeneti értékeit (Huzsvai et al., 2005), ezért elengedhetetlen az ezekből fakadó léptékfüggő problémák megfogalmazása és vizsgálata.

\subsection{TALAJ-NÖVÉNY-LÉGKÖR RENDSZER MODELLEZÉSE}

Az általam megvizsgált modellek a talaj-növény-légkör rendszer folyamatait különböző függvényekkel, illetve azokból felépülő eljárásokkal írják le. Az eljárások egy része a talajban történő víz-, tápelem- és hőforgalmat írják le, míg más részük a modellezett növénykultúra fejlődését és növekedését jellemzik (Fodor et al., 2001). Mind a talajban, mind pedig a növényekben lejátszódó folyamatokat befolyásolja a légkör — a csapadék mennyisége és minősége, a léghőmérséklet, a szél erőssége és a globális besugárzás intenzitása, stb. —, ezért elengedhetetlen, hogy a megbízhatóbb modelleredmények érdekében minél pontosabban adjuk meg a modell bemenő paramétereit, valamint a kezdő-, perem- és kényszerfeltételeket meghatározó változók értékeit.

\subsubsection{Modellezés általában}

A modellek egy összetett, komplex rendszer legfontosabb elemeinek és összefüggéseinek leképezését teszik lehetővé, matematikailag leírható, leegyszerüsített formában (Addiscott, 1993). A szimulációs modellezéshez szükséges a megfelelő informatikai háttér. A kellően nagy számítási kapacitáson túl optimális és precíz adatfelvételezés, hogy minél teljesebb és valósághübb képünk legyen a rendszerváltozók (pl. talajtulajdonságok) térbeli és időbeni variabilitásáról, a végbemenő folyamatok mechanizmusának és azok befolyásolási 
lehetőségeinek ismeretéről annak érdekében, hogy megbízható eredményt kapjunk (Rajkai, 2001).

A modellezésnek több célja lehet. Egyrészről drága és/vagy nehezen kivitelezhető méréseket helyettesíthetünk a megfelelő modell szimulációval, továbbá a különböző talaj-, biológiai- és légköri folyamatok megértésében lehetnek azok segítségünkre. A modellek egyre több és egyre többféle gyakorlati alkalmazásban (pl. döntéstámogató rendszerekben) is szerepet kapnak.

\subsubsection{Modellek csoportosítása}

A modelleket csoportosíthatjuk a modell és a modellezett rendszer közötti kapcsolat meghatározása alapján: kvalitatív modellek, melyek leginkább minőségi elemzésre használhatók, illetve kvantitatív modellek, melyekkel mennyiségi következtetések is tehetök. A kvantitatív modellek lehetnek determinisztikusak és sztochasztikusak. Az utóbbi esetben, statisztikai értelemben véletlenszerü kapcsolatot feltételezünk a függő és független változók között, de nem hagyhatjuk figyelmen kívül a folyamatok fejlődési irányát. A determinisztikus modellek esetében a rendszer egy korábbi állapota meghatározza a későbbit (Rajkai et al. 2004; Huzsvai et al., 2005), a modell kimeneti értékeit végső soron a kezdő-, perem- és kényszerfeltételek határozzák meg (Rajkai, 2001), így elemezhető a rendszert jellemző értékek folyamatokra gyakorolt hatása.

A determinisztikus és sztochasztikus modellek további csoportosítása lehetséges szerkezeti felépítésük alapján (Addiscott és Wagenet, 1985b; Hoosbeek és Bryant, 1992), mely szerint a modell lehet bonyolult, vagy egyszerü; funkcionális (empirikus), vagy mechanisztikus természetü. A funkcionális modellek leegyszerüsítik a kulcsfolyamatok leírását és csökkentik a bemenő adatmennyiséget. A mechanisztikus modellek a modellezett folyamatokat az aktuálisan ismert részfolyamataikkal együtt írják le. Ennek következtében jóval összetettebbek és bonyolultabbak, mint a funkcionális modellek (Rajkai, 2001).

$\mathrm{Az}$ időbeliség megjelenik a modellek csoportosításában is statikus és folyamatorientált (szimulációs) modellek formájában. A statikus modellek megfigyelési adatokon alapuló empirikus összefüggéseket alkalmaznak, míg a folyamatorientált modellek a lejátszódó folyamatok összefüggéseit írják le elméleti megfontolásokon alapuló differenciálegyenletekkel (Rajkai, 2001; Huzsvai et al., 2005).

A bonyolultabb szimulációs modellek több modulból épülnek fel. Az egyes modulok különböző modellcsoportokba tartozhatnak, és gyakran különböző léptéküek is.

A továbbiakban az általam használt két modellt ismertetem. 


\subsubsection{D-s vízforgalmi modellek (HYDRUS-1D)}

A nedvességáramlást fizikai törvények szerint is leírhatjuk. Ez esetben a modellezett talajprofilunk vertikálisan rétegzett — az egyes rétegek változó telítettségüek — mely leírása a Richards-egyenlettel (1. egyenlet) (Richards, 1931) történik. Azonban e modellek horizontálisan homogénnek feltételezik azt a talajréteget, melyben a nedvességáramlást szimulálják. Hátrányuk, hogy jelentősen nagyobb az adatigényük, mint a „vödör” típusú modelleknek (ld.: 5.1.1.2), viszont alkalmasak vízháztartási összetevők (infiltráció, evapotranszspiráció, mélybeszivárgás) meghatározására (Móricz, 2011). A hidrológiai modellek nedvességforgalmi modulja igen részletes és pontos, azonban a növényzet fejlődését és hatását leíró moduljuk gyenge, annak ellenére, hogy például a gyökérzet és levélfelület fejlődési üteme hatással van nedvességforgalomra.

Az egydimenziós vízforgalmi modellek közül hazánkban a SWAP (van Dam, 2000) és a HYDRUS-1D (Šimůnek et al., 1998) modellek az ismertebbek, melyek közül az utóbbit alkalmaztam.

A HYDRUS-1D hidrológiai modell, amelyet a US Salinity Laboratory munkatársai fejlesztettek ki (Šimůnek et al., 1998) a víz talajban történő eloszlása tér- és időbeni változásának leírására. A modell szimulálja a talaj víz, hő- és oldottanyag-forgalmát. A HYDRUS-1D program a telítetlen zónában lejátszódó folyamatok közül a következőket modellezi: csapadék beszivárgása, párolgás, kapilláris vízemelés, növényi vízfelvétel, felszíni tócsaképződés és elfolyás. Ezen folyamatok mellett alkalmazzák a modellt a talaj oldottanyag- és sóforgalmának (Ramos et al., 2011) leírására, a telített és telítetlen zónák közötti folyamatok modellezésére (Twarakavi et al., 2008), a talajba kerülő rovarirtó szerek mozgásának (Cheviron és Coquet, 2009) jellemzésére, továbbá a hő-és vízáramlás szimultán modellezésére fagyott és nem fagyott talajok esetében (Zhao et al., 2008). A modell viszont nem számítja a növényi fejlődést, bemenő adatként kell megadni, pl. a levélfelület index mindenkori értékét.

A talajban végbemenő vízáramlás leírásához két talajfizikai összefüggés, a víztartóképesség- és a vízvezetőképesség-függvény szükséges (pl. Fodor és Rajkai, 2004). A HYDRUS-1D a Richards-egyenlet (1. egyenlet) megoldására numerikus sémát alkalmaz (Šimůnek et al., 2013) a két- és háromfázisú zónában lejátszódó vízáramlás leírására:

$$
\frac{\partial \theta}{\partial t}=\frac{\partial}{\partial x}\left[K \frac{\partial h}{\partial x}\right]-S
$$


ahol $\boldsymbol{\theta}$ : a talajnedvesség-tartalom $\left[\mathrm{cm}^{3} \mathrm{~cm}^{-3}\right] \mathbf{t}$ : az idő $[\mathrm{s}] ; \mathbf{h}$ : a vízpotenciál $[\mathrm{m}] ; \mathbf{x}$ a térbeli koordináta $[\mathrm{m}]$; K: a vízvezető képesség $\left[\mathrm{ms}^{-1}\right]$; $\mathbf{S}$ : nyelő tag, mely a növényi vízfogyasztást veszi figyelembe $\left[\mathrm{ms}^{-1}\right]$ (Šimůnek et al., 2013).

A Richards-egyenlet a talaj adott pontjában történő nedvességtartalom időbeli változását írja le (Klute, 1952). A HYDRUS-1D cm-es felbontásban modellezi a talajban történő vízáramlást, de lehetőség van dm-es beállításra is. Így felmerül a kérdés, hogy a két modellfelbontás közötti egy nagyságrendnyi különbség okozhat-e eltérést a modell eredményekben, ha igen milyen mértékben?

A HYDRUS-1D modell talajhőmérséklet számító modulja a mechanisztikus modellek csoportjába tartozik. A talajban történő hőáramlást leíró egyenletét (2. egyenlet), amely a Fourier és az anyagmegmaradás törvényéből levezethető (Cannon, 1984), numerikusan oldja meg:

$\frac{\partial C_{p}(\Theta) T}{\partial t}=\frac{\partial}{\partial x}\left(\lambda(\Theta) \frac{\partial T}{\partial x}\right)-C_{w} \frac{\partial q T}{\partial x}-C_{w} \cdot S \cdot T$

ahol $\boldsymbol{\Theta}$ : a talajnedvesség-tartalom $\left[\mathrm{cm}^{3} \mathrm{~cm}^{-3}\right] ; \boldsymbol{\lambda}$ : a talaj hővezető képessége; $\mathbf{C}_{\mathbf{p}}$ és $\mathbf{C}_{\mathbf{w}}$ a szilárd és folyékony fázis térfogatos hőkapacitás értékei; $S$ : nyelő tag q: a folyadékfázis áramlási sűrüsége. A talaj hővezető képesség kifejezhető Chung és Horton (1987) egyenletéből:

$\lambda(\Theta)=b_{1}+b_{2} \cdot \Theta+b_{3} \cdot \Theta^{0,5}+\beta_{t} \cdot C_{w}|q|$

ahol $\boldsymbol{\beta}_{\mathbf{t}}$ : a hődiszperziós együttható; $\mathbf{b}_{\mathbf{1}}, \mathbf{b}_{\mathbf{2}}$ és $\mathbf{b}_{\mathbf{3}}$ : empirikus paraméterek, melyek a talaj homok, vályog és agyag tartalmából becsülhetők.

\subsubsection{Termésbecslő modellek (4Mx)}

A rendszerszemléletű modellezés alapjait először Forrester (1968) és Meadow (1972) fektették le, melyet többek között Ritchie (1985) ültetett át gyakorlati, szántóföldi növénytermesztésben alkalmazható rendszermodellé. Hazánkban meghatározó Harnos (1985); Kovács (1995); Rajkai (2001); Fodor (2002); Farkas et al.(2005) és Huzsvai (2006) munkái, akik külföldi modellek adaptálásával, vagy saját fejlesztésü modellek segítségével szimulálták a talaj-növény-légkör rendszer föbb folyamatait. 
A termésbecslö modellek müködési elvük alapján lehetnek sztochasztikus vagy determinisztikus modellek (ld. feljebb) (Szász és Tőkei, 1997). Ezen modellek egy csoportját termésszimulációs modelleknek nevezik, melyek a növény-talaj-légkör rendszer folyamatait különböző függvényekkel, illetve az azokból felépített eljárásokkal írják le (Fodor et al., 2001). A termésszimulációs modellek olyan determinisztikus modellek, melyek számításaik során figyelembe veszik a rendszerváltozók időbeli változásait. A mezőgazdasági alkalmazáson túl segíthetnek a termelés folyamán lezajlódó folyamatok jobb megértésében, megismerésében, továbbá alapjai lehetnek a környezetkímélő — és ezáltal fenntartható — földhasználatnak (Huzsvai et al., 2005). Ily módon segíthetnek a gazdálkodók számára a gazdaságosabb mütrágya-felhasználás (Csathó et al., 2009) és öntözéstechnológia kiválasztásában, valamint szaktanácsadási rendszerek alapjául is szolgálhatnak (Csathó et al., 2007), továbbá a klímaváltozás várható hatásainak felderítésére (Fodor, 2012) is alkalmazhatók.

Több, világviszonylatban is elismert és széles körben alkalmazott termésszimulációs modell közül, pl: WOFOST (Boogaard et al., 1998), STICS (Brisson et al., 1998), CropSyst (Stöckle et al., 2003), DSSAT (Jones et al., 2003) a magyar fejlesztésü 4Mx modellt (Fodor et al., 2001) választottam, mivel azt a hazai körülményekre dolgozták ki (Fodor és Kovács, 2001; Fodor, 2002; Fodor et al., 2003).

A 4Mx modell napi léptékü, deciméteres talajszelvény felbontású, determinisztikus modell, mely szimulálja mind a növényi folyamatokat, pl. asszimilációt, biomasszagyarapodást, levélfelületet, a gyökérnövekedés ütemét, mind pedig a talajban lejátszódó folyamatokat, pl.: víz-, hőmérséklet- és tápanyagforgalmat. Alapjául Ritchie (1991) CERES modellje szolgált. A 4Mx termésszimulációs modell egyetlen növényfaj fejlődését, növekedését írja le, elsősorban meteorológiai adatok (hőmérséklet, csapadék, globális besugárzás, relatív páratartalom, stb.), talaj fizikai jellemzők és tápanyag tartalom értékek alapján, hogy a várható növényi termésre prognózist adjon. A termés mennyisége, minősége, a vetés, érés és aratás időpontja évről évre változik, melyet nagymértékben befolyásol az időjárás (Szász és Tőkei, 1997). A 4Mx modell fő erőssége a növény modul, mely részfolyamatokkal együtt írja le a modellezendő növény fejlődési ütemét.

A 4Mx termésszimulációs modell (1. ábra) napról napra kiszámítja, hogy a napsugárzásból a fotoszintézis útján mekkora tömegű biomassza keletkezik a növényben, ez az anyag miként oszlik szét az egyes szervek között, a levélbe jutó újonnan megtermelt anyag mennyivel növeli a levél felületét, és végső soron kiszámítja a termést. Mindeközben a modell nyomon követi azt, hogy a növény mennyi vizet, illetve tápanyagot vesz föl a talajból, ennek hatására hogyan szárad ki a talaj illetve hogyan szegényedik el tápanyagban, és az esetlegesen 
kritikus érték alá csökkenő nedvesség- illetve tápanyagtartalom miként lassítja a növény növekedését; a növény nedvesség, illetve tápanyaghiányt szenved, sőt a vízhiány következtében elszáradhat. Ezzel párhuzamosan a növénytöl független folyamatok szimulációja is megtörténik. A modell kiszámítja a nagyobb mennyiségü csapadékkal a talaj mélyebb rétegeibe mosódó nitrát mennyiségét, illetve meghatározza a talajból a légkörbe jutó $\mathrm{NO}_{\mathrm{x}}$ gázok mennyiségét. A nitrát a talajvízbe jutva elszennyezheti az ivóvíz készleteket, míg az $\mathrm{NO}_{\mathrm{x}}$ vegyületek üvegházhatású gázok. A $4 \mathrm{Mx}$ modell többek között alkalmas az evaporáció, transzspiráció, beszivárgás, nitrogén forgalom, növényi növekedés, biomassza növekedés, asszimiláció folyamatainak szimulálására is.

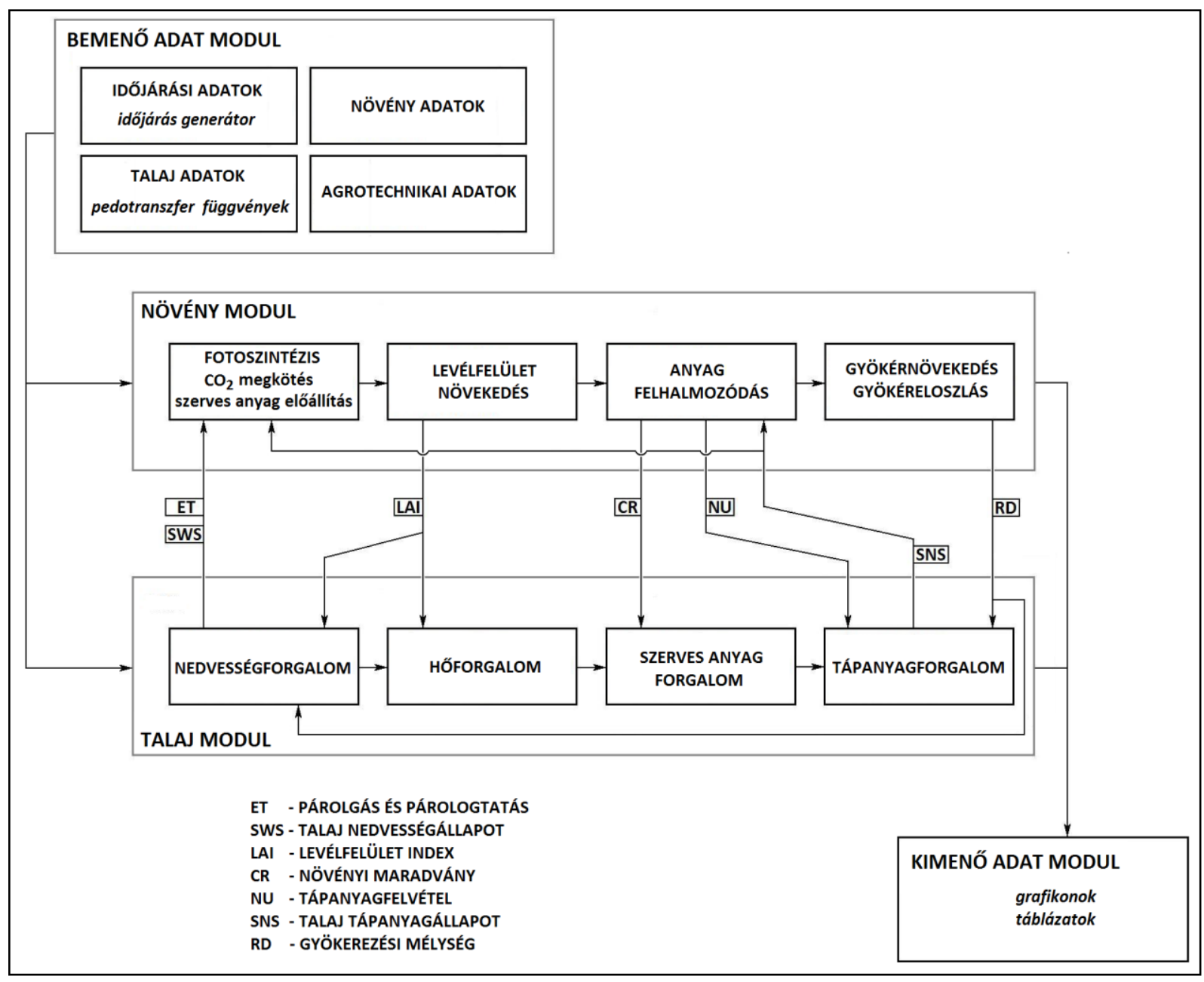

1. ábra: A 4Mx modell folyamatábrája. (Ábra forrása: Fodor, 2012.)

A 4Mx talajhőmérséklet számító modulja az empirikus modelltípusba tartozik (4-5. egyenlet). Egy adott mélység $(\mathrm{x})$ aktuális hőmérsékletének $\left(\mathrm{T}^{\mathrm{i}}\right.$ soil $)$ kiszámításához figyelembe veszi a felső rétegben elnyelt sugárzás mennyiségét és az alsóbb rétegekbe jutásához szükséges időt (1. egyenlet). A felszínre érkező hőenergia hatása nagyobb mélységben késleltetve jelentkezik a felszínhez képest, melyet a 4. egyenlet zárójeles tagja fejez ki. A 4. 
egyenlet exponenciális tagja a feltalaj hő kapacitás értékével áll kapcsolatban, azáltal, hogy csökkenti a felszínre érkező hőenergia mélyebb rétegekre gyakorolt hatását.

$$
\begin{aligned}
& T_{\text {soil }}^{i}(x)=\left[T_{\text {avg }}+\frac{T_{a m p} \cdot \cos \left[0,0174 \cdot(i-I)+x \cdot f_{1}\left(\Theta_{\text {avg } \left., B D_{\text {avg }}\right)}\right)\right.}{2}+F_{D 5}\right] \cdot e^{x \cdot f_{2}\left(\Theta_{\text {avg } \left., B D_{\text {avg }}\right)}^{i}\right.} \\
& F_{D 5}=\frac{\sum_{j=i-4}^{i}(1-A L B) \cdot\left(T_{\text {mean }}^{j}+\left(T_{\text {max }}^{j}-T_{\text {mean }}^{j}\right) \cdot \sqrt{0,03 \cdot S_{\text {rad }}^{j}}\right)}{5}-T_{\text {avg }}-\frac{T_{a m p} \cdot \cos (0,0174 \cdot(i-I))}{2}
\end{aligned}
$$

ahol $\mathbf{T}_{\mathbf{a v g}}$ és $\mathbf{T}_{\mathbf{a m p}}$ : a hely átlaghőmérséklete és átlagos hőingása; $\mathbf{i}$ : az év napja; $\mathbf{I}$ értéke az északi illetve déli féltekén 200, illetve 20; $\boldsymbol{\Theta}_{\text {avg: }}$ a talaj átlagos, térfogatszázalékban kifejezett

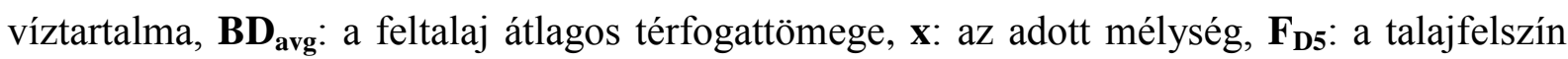
feltételezett szinuszos éves menetét módosító faktor, mely figyelembe veszi az albedó, a globális besugárzás, a napi maximum és minimum hőmérsékletek ötnapos mozgó átlagát, ALB: albedó, $\mathbf{T}_{\text {mean }}^{\mathrm{i}}, \mathbf{T}_{\text {max }}^{\mathrm{i}}$ : napi átlag és maximum hőmérséklet, $\mathbf{S}_{\text {rad }}^{\mathbf{i}}$ globális besugárzás értéke az év i-edik napján.

A 4Mx modell nedvességforgalmi modulja az ún. „vödör” (bucket) modellek csoportjába tartozik, melyek a talajprofil egyes rétegeit homogénnek feltételezik, és amennyiben a tározóterük megtelik, a víztöbbletet mélybeszivárgását vagy felszíni elfolyását feltételezik. Előnyük, hogy minimális az adatigényük (csapadék, potenciális párolgás, talaj víztartó képessége), hátrányuk viszont, hogy a kapilláris emelést leegyszerüsített módon számítják, ezért csak a talajvízhatás mentes területekre alkalmazhatók.

A 4Mx modell nedvességforgalmi modulja az alábbi részfolyamatokat számítja: felszíni elfolyás, párolgás és párologtatás, lefelé illetve felfelé szivárgó víz mennyisége. A talajt egymás alatt elhelyezkedő víztartályok sorozataként modellezi, amelyeket a következő 4 paraméterrel jellemez: szabadföldi vízkapacitás $\left(\boldsymbol{\Theta}_{\mathbf{f c}}\right)$, maximális vízkapacitás $\left(\boldsymbol{\Theta}_{\mathbf{m a x}}\right)$, hervadás ponti vízkapacitás $\left(\boldsymbol{\Theta}_{\mathbf{w p}}\right)$ és telítési vízvezető képesség $\left(\mathbf{K}_{\mathbf{S}}\right)$ (Fodor, 2012). Ha az adott rétegbe érkező víz telíti az adott zónát $\left(\Theta>\Theta_{\max }\right)$, akkor a vízfelesleg a felette elhelyezkedő rétegbe áramlik, mely akár a felszínt is jelentheti, ahol elfolyik, ha a felszín nem sík. Ha a réteg nedvességtartalma $(\Theta)$ nagyobb, mint a szabadföldi vízkapacitás $\left(\Theta_{\max } \geq \Theta>\right.$ $\left.\Theta_{\mathrm{fc}}\right)$ a vízfelesleg (Q) az eggyel lejjebbi rétegbe kerül (6. egyenlet):

$Q=D C \cdot\left(\Theta-\Theta_{f c}\right) \cdot \Delta z$ 
A $\boldsymbol{D C}$ az ún. drén konstans, amely a telítési vízvezető képességből számítható a 7. egyenlet segítségével, $\Delta z$ pedig a réteg vastagsága:

$D C=0,1122 \cdot K_{S}^{0,339}$

Ha a talajréteg nedvességtartalma nem éri el a szabadföldi vízkapacitásét $\left(\Theta_{\mathrm{fc}} \geq \Theta>\Theta_{\mathrm{wp}}\right.$ ) nincs lefelé történő vízmozgás, habár a réteg nedvességtartalma csökkenhet a növényi vízfelvételnek köszönhetően. Amennyiben a talajréteg nedvességtartalma a hervadási ponti vízkapacitás értéke alá csökken, a növényi vízfelvétel megszünik (Fodor, 2012).

\subsubsection{Modellek érvényességi tartománya}

Az adott folyamatot leíró modell mindig egy meghatározott felbontásban lehet csak érvényes, ezért a modell kiválasztásánál a modellezendő folyamat léptéke, érvényességi tartománya meghatározó (Rajkai, 2001). Egy modellt az érvényesítés léptékétől eltérő léptékben használni nem ajánlott, mivel a léptékkel nem csupán a modellezendő terület fizikai mérete változik, hanem a folyamatok kinetikája is (Huzsvai et al., 2005). A részfolyamatokat leíró modulok tér- és időléptékének egymástól függetlennek kell lenniük. Ez azt is jelenti, hogy

amennyiben szakmai ismereteink bővülnek a részfolyamatokról és azokat beépítjük a modellbe, akkor a hatásuk nem jelenhet meg egy másik modellrész folyamataival ellentmondásban (Rajkai, 2001).

További problémát okoz, hogy a meghatározott léptékben részletesen megismert és egzakt módon leírt, pl. hidrológiai összefüggést nem lehet egy másik léptékre méretarányosan átalakítani (Cornelis, 1995), mivel a felszín tulajdonságai heterogének. Azonban egy modell léptékfüggését nem csupán horizontális irányban vizsgálhatjuk, hanem vertikálisan is. Ennek következtében a mérési eredményeinket befolyásolhatja, hogy a talajprofil mentén milyen szimulációs és/vagy mintavételi lépésközt alkalmazunk.

A legtöbb esetben a bemenő adatok és a modellparaméterek egyszerre rendelkeznek térbeli és időbeli heterogenitással is, melyeket nehéz különválasztani. Így a modellezés során figyelembe kell venni az időbeli változékonyságot és a területi változatosságot is, mivel a modelleknek különböző folyamatokat leírására hivatottak így eltérő az érzékenységük is. A mintaterületen belül jelentősen eltérhet az agyag, a szervesanyag-tartalom, a térfogattömeg vagy más talajjellemző változatosságának illetve változékonyságának a mértéke. Ezért fontos, hogy a változatosságot és változékonyságot mely (talaj)tulajdonságra nézzük. A mérések során célszerü a legváltozékonyabb (talaj)tulajdonsághoz igazítani a megfigyelés léptékét, 
mivel a lépésközön belül homogénnek tekintjük az adott (talaj)tulajdonságot a mintavételezés idején.

\subsubsection{Modell kalibráció}

A modell kalibráció iteratív eljárás, mely során különböző folyamatokat szimulálunk számítási modellel, néhány kiválasztott paraméter értékének fokozatos változtatásával, miközben a kapott számítási eredményeket összehasonlítjuk a mért (valós) eredményekkel (Kovács és Szanyi, 2005). Modell kalibrációt követően azt várjuk, hogy az alkalmazott modell — adott léptéken érvényes — valósághü választ ad a szimulált változóra.

A kalibrációt következetes sorrendben kell végrehajtanunk. Egyrészröl az egyszerủen modellezhető folyamatokból kiindulóan a bonyolultakig, másrészről pedig arra a paraméterre kalibráljunk, ami leginkább befolyásolja a modell kimeneti értékét. Ez utóbbi folyamatát megkönnyítheti az úgynevezett paraméterérzékenységi vizsgálat, mely során a jól müködő modellben az egyes paraméterek racionális szélsőértékei mellett megvizsgáljuk a modell kimeneti értékeit (Kovács és Szanyi, 2005). A modell válaszaiból következtethetünk egyrészről a szimulált rendszer viselkedésére, másrészről, hogy a vizsgált paraméterre érzékeny-e az alkalmazott modell. A növénytermesztési modellek kimeneti értékét egyértelmüen befolyásolja a talaj nedvességtartalma, a talaj hőmérséklete és a levélfelületindex (LAI) értéke, a felsorolás sorrendjében. Amennyiben, pl. a talajhőmérséklet-változását szeretnénk modellezni, fontos, hogy a modellt a levélfelület értékekre kalibráljuk, mivel a jelentősebb növényborítottság mérsékli a talaj felmelegedését (Sándor et al. 2013).

A modell kalibrációt elvégezhetjük ún. inverz módszerrel (Soetaert és Petzoldt, 2010) is, amikor egyéb mért értékek felhasználásával közvetett módon határozzuk meg a kérdéses modellparaméter(ek) értékét.

\subsection{MÉRÉSBÖL és MODELLEZÉSBÖL ADÓDÓ LÉPTÉKFÜGGÉS}

A modellek paramétereinek és bemenő adatainak a térbeli és időbeni változatossága természetesen megjelenik a modell eredményekben, de már az adatok felvételezése során találkozunk a mintavételezésből eredő léptékfüggéssel. Ezen bemenő adatoknak és paramétereknek a léptékfüggését már a modellezés korai szakaszában is vizsgálták (Rao et al, 1977; Addiscott és Wagenet, 1985a). A talajtulajdonságok horizontális és vertikális változatosságán túl meghatározó a folyamatok időbeli dinamikája is. Maga a mérés sem folyamatos, hanem bizonyos időegységenként történik. A mérőmüszernek is van kiterjedése, emiatt nem tudunk vele a terület minden egyes pontján mérni. Ezek következtében méréseink diszkrétek, aminek köszönhetően a mérésből eredő léptékfüggéssel is számolnunk kell. 
A modellek mindig tartalmaznak egyszerüsítéseket a zavaró hatások kiszürésére, illetve az időben változó folyamatok állandósítására ezzel növelve a modell hibáját. (Szász és Tőkei, 1997). A modellezendő természeti folyamatot a modellezés során diszkrét módszerekkel vizsgáljuk, illetve diszkrét egységekre bontjuk fel térben és időben. Például a 4Mx deciméteres, a HYDRUS-1D pedig centiméteres térbeli egységekre — rétegekre bontja fel a talajt függőleges irányban. Az időbeli változást is meghatározott felbontásban (napi, hónapos, éves) szimulálják, a meghatározott időegységen belül pedig átlag értékkel számolnak, ennek következtében az egységen belüli dinamikát figyelmen kívül hagyják. Emiatt a modellek diszkrétek. A fentiek következtében a természetben megfigyelt folyamatokat csak részben tudjuk matematikailag leírni, ezért a modellek nem jellemzik a vizsgálati objektumot teljes komplexitásában.

\subsubsection{A léptékfüggés meghatározása}

Tény, hogy hasonló dolgok, folyamatok a megfigyelés léptékétől függően különbözőképp jelenhetnek meg, melyeknek fontos tudományos és gyakorlati jelentőségük van a földtudományokban (Faybishenko et al., 2003). Mivel a talaj-növény-légkör rendszerben lejátszódó folyamatok mindegyikéhez meghatározott tér-és időskála tartozik (Huzsvai et al., 2005), ezért fontos meghatároznunk, hogy mit is értünk lépték, illetve léptékfüggés alatt.

Térléptéket rokoníthatjuk a felbontással, míg az időléptéket a folyamatok sebességével (Huzsvai et al., 2005). De a léptéket felfoghatjuk úgy is, mint a vizsgált rendszer részét (pl.: különböző jellemzők hossza, terület, mennyisége). Eltérő idő- és térléptéken bekövetkező fizikai folyamatok elemzése és összehasonlítása során felmerülő problémát a léptékáthidalással (bridging the scales) oldhatjuk fel. A legtöbbet alkalmazott lépték-áthidalási megközelítés az ún. skálázás (scaling). A skálázást úgy definiálhatjuk, mint egy kapcsolatot, mely kifejezi, hogy a rendszer tulajdonságai miként változnak a rendszer homogénnek tekintett részeinek méretével. Az információk léptéken keresztüli elemzése - beleértve a felskálázást (finomabb felbontásból a durvább léptékre váltást) és a leskálázást (durvább léptékről a finomabb felbontásra való áttérést) - fontos az ökológiai és talaj rendszerek értelmezésében. Heterogén talajban végbemenő áramlást és anyagmozgást számos terepi, laboratóriumi és modellszimulációs eljárás vizsgálja különböző léptékekben. Mindezek ellenére a léptékfüggés problémája messzemenően nincs megoldva. Ennek egyik oka, hogy a legtöbb laboratóriumi és terepi mérés kis területre $\left(<1 \mathrm{~m}^{2}\right)$ és általában rövid időszak(ok)ra vonatkozik. Következésképp ezen eredmények nagyobb térléptékre $\left(>10^{3} \mathrm{~m}^{2}\right)$ és időléptékre való kiterjesztése nem alkalmazható a modell validálására (Faybishenko et al., 2003). 
A disszertációmban szereplő tér- és időlépték egy-egy vonatkozási tartományt jelöl ahol az egyes mérések, vizsgálatok, illetve modellszimulációk történtek.

\subsubsection{Tér- és időbeli kiterjeszthetőség}

A táj tulajdonságai változatosak és a vizsgált területen megfigyelt talajtulajdonságokat valójában nem lehet alkalmazni másik helyen. Ezért csak egy adott pontra lehet értelmezni a mért adatokat és a közöttük feltárt kapcsolatokat, figyelembe véve a talajtípus sajátosságait (Kutílek és Nielsen, 1994). Megjegyzem, hogy Western és munkatársai (2003) szerint egy adott hely mért tulajdonságai némi információt szolgáltathatnak egy másik pontra vonatkozóan, a pontok közelségének és a vizsgált tulajdonságok variabilitásának függvényében. A talaj nedvességtartalma például két, egymástól $1 \mathrm{~m}$ távolságra lévő pontban valószínüleg hasonlóbb, mint a talaj nedvességtartalma két $1 \mathrm{~km}$ távolságra lévő helyen.

A modellek a szimulált területet homogénnek feltételezik, ezért meghatározó, hogy a megfigyeléseinket mekkora a területen végezzük, milyen mintavételezési távolsággal és módszerrel (Huzsvai et al., 2005) (1. táblázat).

\begin{tabular}{|l|l|l|}
\hline Skála & Lépték & Mérési eljárások \\
\hline i+1 & polipedon (tábla) & $\begin{array}{l}\text { szemcseméret eloszlás, meteorológiai adatok mérése } \\
\text { (csapadék, léghőmérséklet, globális besugárzás, relatív } \\
\text { páratartalom, szélsebesség és -irány) }\end{array}$ \\
\hline i & pedon & $\mathrm{K}_{\mathrm{S}}, \mathrm{WDPT}$, térfogattömeg, Hu, HA, FA \\
\hline i-1 & réteg & $\begin{array}{l}\mathrm{CaCO}_{3}, \mathrm{pH}, \mathrm{pF}, \mathrm{Hu}, \mathrm{TDR}, \mathrm{pF}-\text { mérések, } \\
\text { talajhőmérséklet }\end{array}$ \\
\hline
\end{tabular}

1. táblázat: A doktori értekezésben alkalmazott térléptékek és mérési eljárások. A jelölések definícióit ld. a szövegben.

Talajtanban az $1 \mathrm{~m}^{2}$ már reprezentatív pedon (i-szint) méretnek (talajtani alapegységnek) tekinthető (Huzsvai et al., 2005). A pedon a földfelszín legkisebb felületü (1$10 \mathrm{~m}^{2}$ ), háromdimenziós egysége, — melyet reprezentatív elemi térfogatnak (REV) is neveznek (Holmgren, 1988) —, amely elég nagy ahhoz, hogy jellemezze a talajréteget kapcsolatrendszereivel együtt (Johnson, 1963). A talajtan a pedonon belül homogénnek tekinti a talaj fizikai és kémiai tulajdonságait (Soil Survey Staff, 1999).

Nagyobb léptékben két modellezési technika lehetséges: a REV-ok közötti anyag- és energia forgalom figyelembevétele illetve elhanyagolása. Legtöbbször ez utóbbi történik, ekkor pedig lehetőség van arra, hogy a homogénnek tekintett reprezentatív elemi térfogatokra külön - külön futtassuk a modellt. 
A pedonnál nagyobb léptékü $i$-szintek közül az $i+1$ a polipedont jelöli, mely a pedon területi változatosságát is tartalmazza. A polipedon szinten lehetőségünk van két-és háromdimenziójú modellek alkalmazására, mivel a talajgenetikai folyamatok oldal irányú kiterjesztése is lehetséges ebben a léptéken. Az $i$-1 szint a talajgenetikai szintet jelöli. A talajosztályozási rendszerek többsége az $i$-1 szint fizikai-, kémiai- és biológiai jellemzőit extrapolálja az $i$, vagy még az a fölötti szintekre is (Huzsvai et al., 2005).

A modellek időlépték választását befolyásolja a szimulált folyamatok eltérő sebessége. Rajkai (2001) szerint a talajfolyamatokat három időlépték-csoportra lehet felosztani: (a) rövid idejü (napi, évszakos), középhosszú idejű (10-100 év), és a hosszú idejű (geológiai időlépték, ezer év). Jelen dolgozatomban a rövid időléptékü tulajdonságváltozások, illetve az aktuálisan ható talaj-növény-légkör feltételek dinamikáját vizsgálom. Ezek közé tartozik — az általunk is mért - léghőmérséklet, talajhőmérséklet, talajnedvesség-tartalom, csapadék, térfogattömeg, telítési vízvezető képesség (Richter, 1987; Arnold et al., 1990).

\subsubsection{A meteorológiai adatok szerepe a modellekben}

Az általam alkalmazott 4Mx és HYDRUS-1D modellekben a légkörmodul peremfeltételként jelenik meg. Fő bemenő adatai a globális besugárzás, a léghőmérséklet és a csapadék. (Egyes rendszermodellek figyelembe veszik a páratartalom és szélsebesség adatokat is, de ezek nem minden esetben érhetők el.)

A HYDRUS-1D talajhőmérséklet számító moduljának a fent említett meteorológia adatok mellett szükséges megadnunk a talajfelszín albedóját illetve hőmérsékletét napi felbontásban.

A 4Mx számításait a napi időjárási adatok határozzák meg, de a modell müködéséhez szükség van a légkör-talaj-növény rendszer fizikai (pl.: talaj térfogattömege), kémiai (pl.: a talaj NKP ellátottsága, pH-ja), illetve biológiai (pl.: bázis hőmérséklet) tulajdonságait megadó bemenő adatokra is.

\subsubsection{Hömérséklet}

A 4Mx termésszimulációs modell a napi maximum és minimum léghőmérséklet alapján számolja a napi átlaghőmérsékletet ( $\mathrm{T}_{\text {átlag }}$ ). A hőmérséklet-változás egy idealizált — egyenletesen felmelegedő és lehülő - napra vonatkozik, mely során a hőmérséklet modellezett napi menete szinuszos. A hőmérséklet két szélső értéke alapján számolja a napi hőösszeget, mely az átlaghőmérséklet ( $\mathrm{T}_{\text {átlag }}$ ) és a bázishőmérséklet ( $\mathrm{T}_{\text {bázis }}$ ) 24 órára vonatkoztatott különbsége. A növényi élettevékenység megkezdéséhez egy minimális 
hőmérsékleti érték szükséges, ezt nevezik bázishőmérsékletnek ( $\left.T_{\text {bázis }}\right)$. A bázishőmérsékletet meghaladó hőmérséklet emelkedésével arányosan gyorsulnak a biokémiai reakciók (Varga-Haszonits, 1987). Mivel adott fenológiai fázishoz adott hőfoknap összegérték tartozik, a fejlődési fázis vége előre jelezhető. Ennél fogva a léghőmérséklet alapvetően meghatározza a növényi fejlődés ütemét a termésszimulációs modellekben.

A hőmérséklet-változás más-más képet mutathat attól függően, hogy napi vagy annál rövidebb időléptékben követjük. A megfigyelés léptékétől függhet az is, hogy a hőmérséklet miként befolyásolja a modell által szimulált folyamatokat. Mivel a napi léptékủ modellek a hőmérséklet napi változását idealizált szinuszos napi menetet feltételezve írják le, így elfedhetik a finomabb felbontásban jelentkező különbségeket.

A HYDRUS-1D modell szimulációhoz a vizsgált területre vonatkozó napi felbontású hőmérséklet adatokat szükséges megadnunk kezdő- és peremfeltételként. A napi felbontású átlagos léghőmérséklet értékeken kívül meg kell adnunk a vizsgált talajszelvény felszínének és aljának hőmérsékletét, továbbá a napon belüli hőmérsékleti értékek változásának maximális különbségét. A legtöbb meteorológiai állomáson a napi maximum és minimum hőmérsékleti értéket is rögzítik, így könnyen megadható az amplitúdó értéke. A HYDRUS-1D modell a léghőmérséklet napon belüli változásának kiszámításához - a napi maximum és minimum léghőmérsékleti értékek felhasználásával — koszinusz-függvényt alkalmaz a nap 24 órájában (Kirkham és Powers, 1972):

$T_{\text {air }}=\frac{T_{\max }+T_{\min }}{2}+\frac{T_{\max }+T_{\min }}{2} \cdot \cos \left[2 \pi\left(\frac{t-13}{24}\right)\right]$

ahol: $\mathbf{T}_{\max }$ és $\mathbf{T}_{\mathbf{m i n}}$ : napi maximum és minimum hőmérsékleti értékek [ ${ }^{\circ} \mathrm{C}$; $; \mathbf{t}$ : napon belüli helyi idő [h].

\subsubsection{Csapadék}

A csapadék mennyiségének és időbeli eloszlásának napi léptékben történő megadása fontos bemenő adata a rendszermodelleknek. A legtöbb modell megkülönbözteti az esőt és a havat (pl.: HYDRUS-1D). Az intenzitás megadása azonban problémát jelent a szimulációk során. Nyáron gyakoriak a záporok, melyek során fél óra alatt akár 30-40 mm csapadék is lehullhat. Ez az idő nem minden esetben elegendő a felszínre zúduló víz talajba szivárgására, azaz meghaladja az infiltráció maximális értékét, így felszíni elfolyás történik. A napi léptékü modellek azonban képtelenek pontosan leírni a zivatarok során fellépő jelenségeket. 
Az esőn kívül télen a hónak van fontos szerepe a talaj-növény-légkör rendszerben. A 4Mx modell számítja a hóborítottságot, azonban a hóréteg szigetelö hatásával nem számol, mely következtében a téli talajhőmérséklet modellezése kevésbé valósághü.

Amikor a léghőmérséklet értéke $-2{ }^{\circ} \mathrm{C}$ alá csökken, a HYDRUS-1D modell a beérkező csapadékot hó formájában veszi figyelembe, míg $+2{ }^{\circ} \mathrm{C}$ felett folyadék halmazállapotúnak. -2 ${ }^{\circ} \mathrm{C}$ és $+2{ }^{\circ} \mathrm{C}$ között a hidrológiai modell lineáris átmenetet feltételez a két halmazállapot (szilárd hó és folyékony eső) között (Jarvis, 1994). Továbbá azt feltételezi, hogy a hóréteg olvadása hőmérséklet-arányosan történik, amikor a léghőmérséklet $0{ }^{\circ} \mathrm{C}$ fölé emelkedik. Ezt az arányossági állandót hó olvasási állandónak (Snow Melting Constant) nevezik, mely azt a hó mennyiséget jelöli (víz cm-ben megadva), amely 1 nap alatt elolvad adott hőmérsékleten. A hóréteg potenciális párolgását csökkenthetjük a szublimálási állandó (Sublimation Constant) állításával.

\subsubsection{Sugárzás}

A sugárzás hat a növényi fejlődés és asszimiláció ütemére, az evaporáció és transzspiráció mértékére. Amennyiben nem rendelkezünk mért napi felbontású globálsugárzás adatokkal, a 4Mx modellt alkalmazva két becslőeljárás közül választhatunk. A Szász-féle eljárás (1968) a napsütéses órák számából határozza meg a globális besugárzás értékét. A Fodor-Mika módszer (Fodor és Mika, 2011) a napi hőmérséklet minimumát és maximumát használja a becsléshez, és más összefüggéseket alkalmaz csapadékmentes és csapadékos napokra. A 4Mx modell a napi globális besugárzásadatok felhasználásával számítja a potenciális evapotranszspiráció napi értékét (Priestley és Taylor, 1972).

A HYDRUS-1D modell a napi felbontású globális besugárzás adatokat használja fel többek között a felhőzöttségi tényező, beérkező rövidhullámú sugárzás (Campbell, 1985), és az evapotranszspiráció értékének kiszámításához. A HYDRUS-1D programmal a potenciális evapotranszspiráció értékét két módon számíthatjuk ki: 1.) a Hargreaves-egyenlettel (Hargreaves, 1994; Jensen et al., 1997) és 2.) a Penman-Monteith-féle (Monteith, 1981; Monteith és Unsworth, 1990; FAO, 1990) módszerrel. Mindkét számítás megköveteli a napi felbontású sugárzás, hőmérséklet, szélsebesség és relatív páratartalom adatok megadását, azonban a Penman-Monteith-féle eljárás részletesebben figyelembe veszi a sugárzási és aerodinamikai határfelületek kölcsönhatásait (FAO, 1990).

\subsubsection{A meteorológiai adatok léptékfüggése}

A meteorológiai változókat területileg egységesnek tekinthetjük, ha viszonylag kis területen, lokálisan végezzük vizsgálatainkat. A vegetációs időszak alatt a beszivárgás és 
evapotranszspiráció térbeli heterogenitásának az egyik fö oka a csapadék változékony elosztása és a talajszerkezet változatossága (Gutmann és Small, 2005; Zhu és Mohanty, 2002). A csapadék területi eloszlását abban az esetben homogénnek tekinthetjük, ha a vizsgált terület terjedelme nem haladja meg a $100 \mathrm{~m}^{2}$-t (Waymire és Gupta, 1981; Witter, 1984). A globális besugárzás, léghőmérséklet, relatív páratartalom és csapadék értékek időben mutatnak jelentősebb változékonyságot illetve napi és évszakos periodicitást.

A talaj nedvességtartalma és a növényzet két kritikus és szoros kapcsolatban álló eleme a talajfelszín kölcsönhatás rendszerének, amelyek térben és idöben változatosak és változékonyak (Kim és Wang, 2005). A talaj tápanyagtartalmán és nedvességállapotán túl a növényi növekedés fö meghatározója a hőmérséklet. A napi minimum és maximum hőmérsékleti értékek rögzítése esetén azonban nem jelennek meg a finomabb felbontásban pl. 5 perces felvételezéskor — észlelhető különbségek. Ez különösen fontos a növényi fejlődés első szakaszában, mivel ha a hőmérséklet a bázishőmérsékletet nem éri el, a növény élettevékenysége lelassul vagy szünetelhet is (Varga-Haszonits, 1987). A tavaszi időszakban előfordulhat, hogy a napi maximum és minimum hőmérsékletek átlag értéke a $T_{\text {bázis }}$ alatt marad, miközben a finomabb felbontás esetén akár több órán keresztül is a bázishőmérséklet feletti értékeket rögzíthetünk. Ezek miatt fontos, hogy milyen gyakorisággal mérjük a hőmérsékleti értékeket.

\subsubsection{A talajhőmérséklet léptékfüggése}

A talajhőmérséklet az egyik legfontosabb talajváltozó. Befolyásolja a csírázást (Nabi és Mullins, 2008), a növényi növekedést (Liu és Huang, 2005), a tápanyag felvételt (Dong et al., 2001), a talaj légzést (Boone et al., 1998; Yang és Cai, 2006), az evaporációt (Katul és Parlange, 1992) és a talajban lejátszódó fizikai (Rahi és Jensen, 1975), kémiai (Paraíba et al., 2003; Zhou et al., 2007) és mikrobiológiai folyamatok (Olness et al., 2001; Pietikäinen et al., 2005) sebességét. Bár nem minden esetben állnak rendelkezésünkre mért talajhőmérsékletadatok $\left(\mathrm{T}_{\text {soil }}\right)$, de meteorológiai adatok és más paraméterek felhasználásával, előállíthatók. Ezen számítások alapulhatnak egyszerü léghőmérséklet-adatokon (pl.: Hasfurther és Burman, 1974), de pontosabb értékeket kaphatunk, ha a csapadékadatokat (Zheng et al., 1993) is figyelembe vevő módszert választunk. A fentieken túl a levélfelület-index (LAI) értéke és a talajnedvesség dinamikája is jelentős mértékben meghatározza a talajhőmérséklet dinamikáját (Sándor és Fodor, 2012a). 
A talajhőmérséklet rendelkezik éves és napi változékonysággal, melyek különböző mértékben befolyásolják a talajtulajdonságokat és a növényi növekedés ütemét (Rajkai, 2001). A modellezés során mindezeket figyelembe kell vennünk.

\subsubsection{A talaj nedvességforgalmát meghatározó modell-paraméterek}

A talaj nedvességtartalma szabályozza a növényi növekedést és ezáltal a szárazföldi ökoszisztémák termékenységét továbbá fontos befolyásolója a talajfolyamatok változatosságának, beleértve az eróziót, a talajkémiai folyamatokat, az oldott anyag szállítását és végső soron a talajképződést (Western et al., 2003).

A talaj nedvességforgalmának leírásához elengedhetetlen a talaj víztartó képességének ismerete (Várallyay, 2004, 2005a, 2005b), melyet elsősorban a talaj mechanikai összetétele határoz meg. A modellezés szempontjából azonban alapvető problémát jelent, hogy a folytonos víztartóképesség-függvény, $\mathrm{pF}$ mérésekből származó néhány pontja ismert csupán, melyeket pF-pontoknak is neveznek. A pF-érték a talajban lévő nedvességtartalom eltávolításához szükséges, vízoszlop cm-ben kifejezett szívóerő tízes alapú logaritmusa (Schofield 1935). Magyarországon Várallyay György által kidolgozott és bevezetett módszer honosodott meg (Várallyay, 1973b, 1978, 1987): a pF-görbe meghatározásához a $100 \mathrm{~cm}^{3}$-es mintákat vízzel telítjük, majd homok-, illetve kaolinlapos mérőedényekbe helyezzük, végül nyomásmembrános készülékben mérjük meg a víztartóképesség-függvény jellegzetes pontjait. Leggyakrabban a $\mathrm{pF}=0,0 ; 1,0 ; 1,4 ; 1,5 ; 2,0$; 2,$3 ; 2,7 ; 3,4 ; 4,2$ és 6,2 nedvességpotenciálnak megfelelő nedvességtartalmat határozzuk meg. Azokban a modellekben (pl.: 4Mx), ahol egyszerüsített vízmozgás modellezés van, a $\boldsymbol{\Theta}_{\mathbf{m a x}}$, $\boldsymbol{\Theta}_{\mathrm{fc}}$ és $\boldsymbol{\Theta}_{\mathrm{wp}}$ paramétereket a $\mathrm{pF}=0 ; 2,3$ és 4,2 nedvességtartalmakkal szokás azonosítani. A mérés időigényes — a teljes víztartóképesség-görbe meghatározásához 2-3 hónap is kellhet —, ezért több módszert is kidolgoztak a pF-görbe értékek egyéb talajtulajdonságok (szemcsefrakció, szervesanyag-tartalom, térfogattömeg) alapján történő becslésére (Rajkai, 2004). A pF-görbe analitikus leírására a van Genuchten-féle függvényt (1980) alkalmazzuk. A talajban történő vízmozgás leírásához azonban elengedhetetlen a víztartóképességfüggvény mellett a vízvezetőképesség-függvény megadása. A talaj vízvezető-képessége K(h) a talajnedvesség-potenciál exponenciális jellegü függvénye (Gardner, 1958), melynek gyakorlati meghatározása bonyolult és időigényes (Rose et al., 1965; Bouma et al., 1971; Clothier és White, 1981; van Grinsven et al., 1985; Várallyay, 1993). Emiatt általában csak a talaj telítési vízvezető képességét $\left(K_{S}\right)$ mérjük. A vízvezetőképesség-függvényt a $K_{S}$ és a relatív vízvezetőképesség-függvény: $\mathrm{K}_{\mathrm{r}}(\mathrm{h})$, szorzataként írhatjuk fel (van Genuchten, 1980; 
Rajkai, 1984). A $\mathrm{K}_{\mathrm{r}}(\mathrm{h})$ függvény paramétereit leggyakrabban a van Genuchten-féle víztartóképesség-függvény paramétereiből származtatják (Mualem, 1976; van Genuchten, 1980) (9-11. egyenlet):

$$
\begin{aligned}
& S(h)=\left[1-(1-\alpha \cdot h)^{n_{1}}\right]^{-n_{2}} \\
& K(S)=K_{S} \cdot S^{l}\left[1-\left(1-S^{1 / n_{2}}\right)^{n_{2}}\right]^{2} \\
& K(h)=K_{S} \frac{\left\{1-(\alpha \cdot h)^{n_{1}-1}\left[1+(\alpha \cdot h)^{n_{1}}\right]^{-n_{2}}\right\}^{2}}{\left[1+(\alpha \cdot h)^{n_{1}}\right]^{n_{2} l}}
\end{aligned}
$$

ahol $\mathbf{K}_{\mathbf{S}}$ : telítési vízvezető képesség $\left[\mathrm{m} \mathrm{s}^{-1}\right], \mathbf{K}(\mathbf{h})$ : aktuális vízvezető képesség $\left[\mathrm{m} \mathrm{s}^{-1}\right.$ ], $\mathbf{h}: \mathbf{a}$ talaj nedvességpotenciálja [m], $\mathbf{S}$ : relatív telítettség [ ], $\boldsymbol{\alpha}$ és $\mathbf{n}$ : a van Genuchten-függvény együtthatói, amelyek a függvény alakját adják meg, $\mathbf{l}$ : talajspecifikus paraméter, $\mathrm{n}_{2}=1-\mathrm{n}_{1}{ }^{-1}$.

A 4Mx, illetve a HYDRUS-1D modell is tartalmaz egy segédprogramot, mely a mért pF-adatokra van Genuchten-féle (1980) víztartóképesség-függvényt illeszt és meghatározza az alfa és $\mathrm{n}$ paraméterek értékét. Amennyiben nem rendelkezünk mért hidraulikus vezetőképesség-adatokkal, a vízzel telített talaj hidraulikus vezetőképessége becsléssel, úgynevezett pedotranszfer függvény $(P T F)$ (Bouma, 1989) alkalmazásával is meghatározható, melyre világszerte több módszert is kidolgoztak (többek között: Campbell, 1985; Jabro, 1992; Wösten et al., 1999; Suleiman és Ritchie, 2001; Nemes et al., 2005). A pedotranszfer-függvények a talaj alapvető jellemzőinek, pl.: szemcseméret-eloszlás, térfogattömeg, szervesanyag-tartalom, ismeretében regressziós egyenletek segítségével adnak becslést a keresett paraméterekre (Huzsvai et al., 2005). A 4Mx modellhez kapcsolt TALAJTANonc program (Fodor és Rajkai, 2005) segítségével több $K_{S}$ becslésére kidolgozott PTF-t is alkalmazhatunk.

\subsubsection{A nedvességforgalmat jellemző paraméterek és adatok léptékfüggése}

A víz- és tápanyagtranszport folyamatok fó mozgatóereje a talajnedvesség potenciálkülönbsége, ezért is fontos minél pontosabban megállapítani a talaj nedvességállapotát, illetve a nedvesség talajszelvényen belüli eloszlását. A talajnedvességtartalom térbeli illetve időbeni változatosságára illetve változékonyságára számos tényező hatással van, többek között a topográfia, a talaj tulajdonságok, a talajvíztükör mélysége, a 
csapadék mennyisége és éven belüli eloszlása, a talajt borító növényzet típusa, és a globális besugárzás (Famiglietti et al., 1998).

A víztartóképesség-függvényt a modellezés során állandónak tekintjük, de Farkas (2001) rámutatott, hogy ez a talajtulajdonság a vegetációs időszak alatt jelentős szezonális dinamikával rendelkezik. Továbbá, még viszonylag homogénnek tekintett termőhelyen is különbségek mutatkozhatnak a felvehető vízkészlet mennyiségében a pF-görbe területi változatossága miatt (Farkas, 2001).

A talaj víztartó képességét többen vizsgálták (Gupta és Larson, 1979; Várallyay, 1987; Rajkai, 1987; Romano és Palladino, 2002; Farkas, 2001; Rajkai et al., 2004; Haverkamp et al., 2005; Tóth, 2010), míg a talaj hidraulikus vezetőképességét kevesebben (Rajkai, 2004). A modellek nedvességforgalmát a talaj telítési vízvezető képessége $\left(K_{S}\right)$ is nagy mértékben meghatározza (Kutílek, 2004), ezért fontos, hogy minél pontosabb ismeretekkel rendelkezzünk a vizsgált talaj hidraulikus vezetőképességére vonatkozóan.

\subsubsection{A telítési vízvezető képesség meghatározása}

A termésszimulációs modellek egyik legfontosabb, talajban lejátszódó nedvességáramlást befolyásoló paramétere, a telítési vízvezető képesség (Zhang, 1997). A $K_{S}$ egyben a talajok egyik legnagyobb variabilitású paramétere (Upchurch et al., 1988), ezért célszerü a modellezendő talajon mért érték(ek) használata (Fodor et al., 2009). A talaj hidraulikus vezetőképessége mérésének két fő típusát különböztetjük meg: a nyomás alatti beszivárgást és a szívóerő melletti beszivárgást. Amennyiben nyomást alkalmazunk a talaj bruttó, azaz

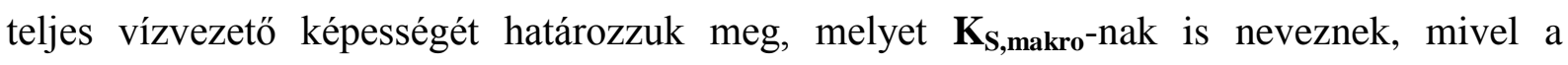
makropórusokon keresztüli beszivárgást is mérjük. A makropórusok olyan átmérőjü csatornák, amelyekben az áramlás hajtóereje a gravitációs potenciál (Huzsvai et al., 2005). Szívóerő beállításával és a makropórusok kizárásával a talajmátrix telítési vízvezető képességét $\mathbf{K}_{\mathbf{S} \text {,matrix }} \mathrm{t}$ mérjük meg.

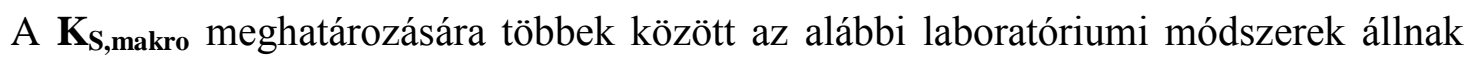
rendelkezésünkre: csökkenő vízoszlop módszere $100 \mathrm{~cm}^{3}$-es mintákon (Várallyay, 1973a) illetve az állandó vízoszlop módszere a Booltink-féle (1991) $6280 \mathrm{~cm}^{3}$-es mintákon. A terepi módszerek közül a dupla keretes (Aronovici, 1955) és a Guelph permeaméteres mérések, továbbá a becslő eljárások közül Jabro (1992) és Wösten és munkatársai-féle (1999)

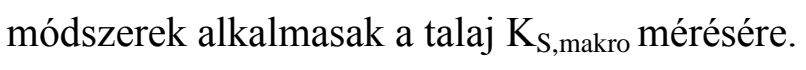

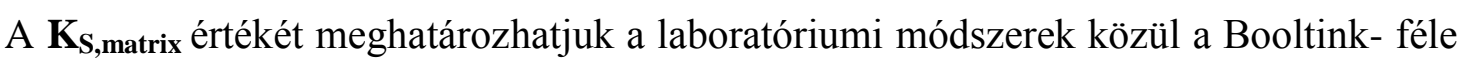
(1991) kéreg eljárással, a terepi módszerek közül a Tension Disc Infiltrométerrel (Wooding, 
1968) és a Mini Disk Infiltrométerrel (Decagon, 2010); továbbá a becslő eljárások közül Campbell (1985) és Suleiman és Ritchie-féle (2001) eljárás alkalmas a talaj mátrix vízvezető képességének mérésére.

\subsubsection{Laboratóriumi módszerek}

A kispatronos, $100 \mathrm{~cm}^{3}$-es minták esetében a talaj makropórus vízvezető képességét ( $\mathrm{K}_{\mathrm{S} \text {,makro}}$ ) csökkenő vízoszlop módszerével (Várallyay, 1973a) határozzuk meg. Fontos, hogy a mintavétel idején a talaj ne legyen se túl száraz, se túl nedves (Fodor et al., 2009). A vízvezető képesség méréshez begyüjtött eredeti szerkezetü talajmintákat először vízzel kell telíteni. A telítéshez szükséges időt befolyásolja az agyagtartalom, míg homokoknál ez az idő 3 nap, addig a magas agyagtartalmú talajoknál egy hét is lehet. Fodor és munkatársai (2009) a mintavételezés során szilikon zsírral bekenték a mintavevő patronok belső falát, mellyel kiküszöbölték a mérési eredményt jelentősen befolyásoló falhatást, így a kapott Ks értékek nem különböztek az etalonnak számító nagypatronos mintákétól homoktalaj esetében.

A nagypatronos minták estében a $\mathrm{K}_{\mathrm{S} \text {,makro }}-\mathrm{t}$ az állandó vízoszlop módszerével határozzuk meg. Ezt a módszert Booltink és munkatársai (1991) dolgozták ki, illetve Fodor és munkatársai fejlesztették tovább (Fodor et al., 2011). Ugyanazon nagypatronos minta

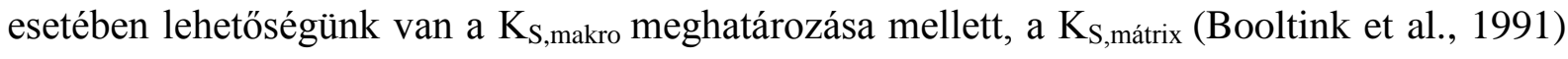
mérésére is, mely utóbbit „kéreg” módszernek neveznek (Fodor et al., 2009). Ezt az eljárást Magyarországon Fodor és munkatársai $(2009,2011)$ honosították meg.

\subsubsection{In situ módszerek}

A terepi mérések esetében a talaj nem telítődik, ezért ezek a módszerek csak ún. telítésközeli hidraulikus vezetőképesség $\left(\mathrm{K}_{\mathrm{fs}}\right.$, field saturated $)$ értékeket szolgáltatnak (Reynolds és Elrick, 1986).

Az in situ módszerek közül a duplakeretes módszert (Double Ring) (Aronovici, 1955) tartják a leghitelesebbnek, mellyel a $\mathrm{K}_{\mathrm{S} \text {,makro }} \mathrm{t}$ tudjuk meghatározni. A vizsgálat során belső és külső, általában 20 és $40 \mathrm{~cm}$ átmérőjü gyürüt nyomunk a talajba. A belső keretben és a keretek között néhány cm magas vízréteget tartunk fenn, közben feljegyezzük a belső gyürü vízutánpótlását biztosító Mariott-palackból időegység alatt kifolyó víz mennyiségét (Fodor et al., 2009). A fentiek ismeretében, a Darcy-egyenlet alkalmazásával kiszámítható a telítési vízvezető képesség. A módszer előnye, hogy olcsó, könnyen kezelhető, továbbá csak a vertikális irányú szivárgást mérjük, mivel az oldal irányú elszivárgást a külső gyürü alkalmazásával kiküszöböljük. Azonban a duplakeretes módszerrel mért vezetőképesség 
értékek nem függetlenek a keretek méretétöl (Gregory et al., 2005; Lai és Ren 2007), tehát léptékfüggőek.

A Guelph permeaméter (Reynolds és Elrick, 1986) részletes leírása és bemutatása a 6.2.2.2. fejezetben olvasható.

A Tension Disc Infiltrométer (Wooding, 1968) és a Mini Disk Infiltrométer

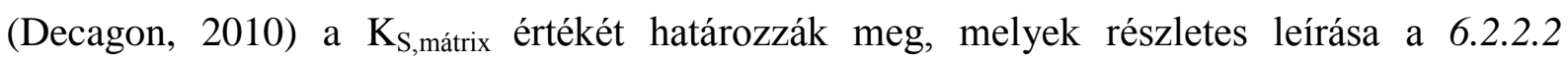
fejezetben olvasható.

\subsubsection{Becslö függvények}

A talajok telítési vízvezető képességét különböző pedotranszfer függvények (PTF) alkalmazásával is számíthatjuk, melyek közös jellemzője, hogy egyszerübb és

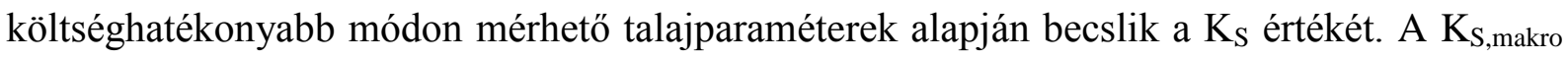
értékének meghatározására használhatjuk Jabro (1992) módszerét, melyet az amerikai UNSODA (Leij et al. 1996) adatbázison dolgozott ki, illetve Wösten és munkatársai (1999) módszerét, melyet az európai HYPRES (Lilly, 1997; Wösten et al., 1999) adatbázisra alapoztak. Ezen becslésekhez szükséges megadni a talaj térfogattömegét, mechanikai összetételét, illetve humusztartalmát.

Campbell (1985) által kidolgozott becslőmódszer a talaj makropórus nélküli vízvezető képességét $\left(\mathrm{K}_{\mathrm{S} \text {,mátrix }}\right)$ határozza meg. A bemenő térfogattömeg és mechanikai összetétel adatok felhasználásával, fizikai megfontolások alapján számol. Fodor és munkatársai (2009) szoros egyezést mutattak ki a „kéreg” módszer és a Campbell-féle módszer eredményei között homoktalajon. A Suleiman és Ritchie (2001) szintén a talaj

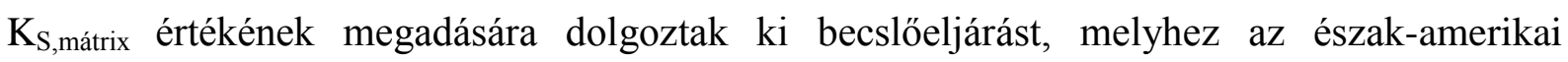
UNSODA adatbázist használták.

\subsubsection{A telítési vízvezető képesség mérés léptékfüggése}

A telítési vízvezető képesség mérésének laboratóriumi eljárásait tekintve, Várallyay (1973a) szerint a szabványos $100 \mathrm{~cm}^{3}$-es, $5 \mathrm{~cm}$ magas talajminta nem feltétlenül reprezentálja a megmintázott talajréteg telítési vízvezető képességét. A Booltink-féle (1991) nagypatronos mintából mért $K_{S}$ érték feltehetően közelebb áll a valósághoz, mivel $5650 \mathrm{~cm}^{3}$-es (Fodor et al., 2011) térfogatával és $20 \mathrm{~cm}$-es magasságával, másfél nagyságrenddel nagyobb talajtérfogatot jellemez, mint a kispatronos mintavétel.

Az in situ módszerek tekintetében szintén felmerül a mérési felületek nagyságrendnyi eltéréséből származó léptékfüggés problémája. A Mini Disk Infiltorméter mérési felület 
átmérője 4,5 cm, míg a Tension Disc Infiltrométeré $20 \mathrm{~cm}$. Ennek következtében a TDI nagyobb mérési felületével elfedheti a területi heterogenitást, mely a MDI mérések segítségével kimutatható lehet.

\subsubsection{A talaj víztaszítás}

Függetlenül attól, hogy terepi vagy laboratóriumi, nyomás alatti vagy szívóerő melletti vízbeszivárgást vizsgálunk, az eredmények kiértékeléséhez állandósult infiltrációs ütem szükséges. Az egyenletes beszivárgást jelentősen befolyásolhatja, ha víztaszító, vagy nehezen nedvesíthető talajon végezzük a hidraulikus vezetőképesség méréseinket. Ezt a jelenséget a talajok víztaszításának (soil water repellency) nevezik, mely témával világszerte sokan foglalkoznak (Dekker és Ritsema, 1994; Doerr et al., 2000; Hallett, 2007; Lichner et al., 2006), de hazánkban még alig kutatott téma.

Néhány talaj bizonyos körülmények között víztaszítóvá válhat, mely jelentősen befolyásolhatja a talajok hidrológiai tulajdonságait. Dekker és Ritsema (1996) öt talajnedvesíthetőségi kategóriát különböztet meg a felszínre helyezett vízcsepp beszivárgáshoz szükséges idő (t) alapján: (1) nedvesíthető (wettable), vagy nem víztaszító (non water repellent) $(\mathrm{t}<5 \mathrm{~s})$; (2) kissé víztaszító (slightly) ( $\mathrm{t}=5$ - $60 \mathrm{~s})$; (3) közepesen víztaszító (strongly) ( $\mathrm{t}=60-600 \mathrm{~s}) ;(4)$ erősen víztaszító (severely) ( $\mathrm{t}=600-3600 \mathrm{~s}$ ); (5) extrém víztaszító (extremely water repellent) ( $\mathrm{t}>3600)$. A kritikus mértéket meghaladó víztaszítás világszerte több helyen kimutatható (Dekker et al., 2005), mely hatással van a talajok hidrológiai tulajdonságaira, s ezáltal az ökoszisztémák produktivitására is. A kismértékü víztaszítás már késlelteti a beszivárgás elindulását, de nem akadályozza meg (Hunter et al., 2011), továbbá befolyásolja a felszíni lefolyás mennyiségét (Doerr, 1998, Lichner et al., 2012) is. A talajok víztaszításának mértéke függ a talaj nedvességtartalmától. A két jellemző között fordított arányosság áll fenn (Doerr és Thomas, 2000). A száraz víztaszító talaj általában nehezen nedvesedik át csapadék vagy öntözés hatására (Dekker et al., 2001), de ha már átnedvesedett, könnyen beszivárog a víz. Talajmüveléssel a víztaszítás mértéke jelentősen csökkenthető (Hallett et al., 2001).

A víztaszítás egy átmeneti talajtulajdonság, mely igen nagymértékü térbeli változatossággal (Ritsema és Dekker, 2003) és időbeli változékonysággal rendelkezik (Rodríguez-Alleres és Benito, 2011) hasonló vegetációs körülmények között. 


\subsubsection{Léptékfüggő problémák kezelése átlagolással}

A talajfolton belüli változatosságot kezelhetjük úgy, hogy a modell kimenetét befolyásoló bemenő talajparamétereket, pl. hidraulikus vezetőképesség értékeket, a modell futtatása előtt átlagoljuk (Interpolate the inputs, Calculate later; IC) és az így kapott átlagértéket írjuk a modellbe, mint bemenő paraméterként. Tehát az átlagolást a modell futtatása előtt végezzük el. A módszer elnevezésére az angolból átvett IC jelölést alkalmazom a továbbiakban. A másik lehetőség, hogy az eltérő bemenő értékekkel kapott modell-eredményeket a szimuláció után átlagoljuk (Calculate first, Interpolate later; CI) (Stein et al., 1991; Bechini et al., 2000). A továbbiakban ezt a módszert CI-vel jelölöm.

Az IC technika a modellezendő területről azt feltételezi, hogy teljesen homogén, ezáltal elfedi az esetleges térbeli változatosságot és ezzel együtt a léptékfüggést is. Míg a CI technika sok, egymástól eltérő tulajdonságú talajfoltot feltételez, és az összes, külön szimulált modell eredmények átlagát adja végeredményül. Ezáltal megjeleníti a talajtulajdonságok térbeli heterogenitását. 


\section{ANYAG és MÓDSZER}

\subsection{MINTATERÜLETEK}

A talaj-növény-légkör rendszer modellezésének léptékfüggő problémáit 5 mintaterületen vizsgáltuk (2. ábra). Az őrbottyáni és csólyospálosi vizsgálati területeken homoktalaj, Martonvásárban homokos-vályog, Nagyhörcsökön vályog, míg a szurdokpüspöki mérési területen agyag szemcseösszetételü talaj található.

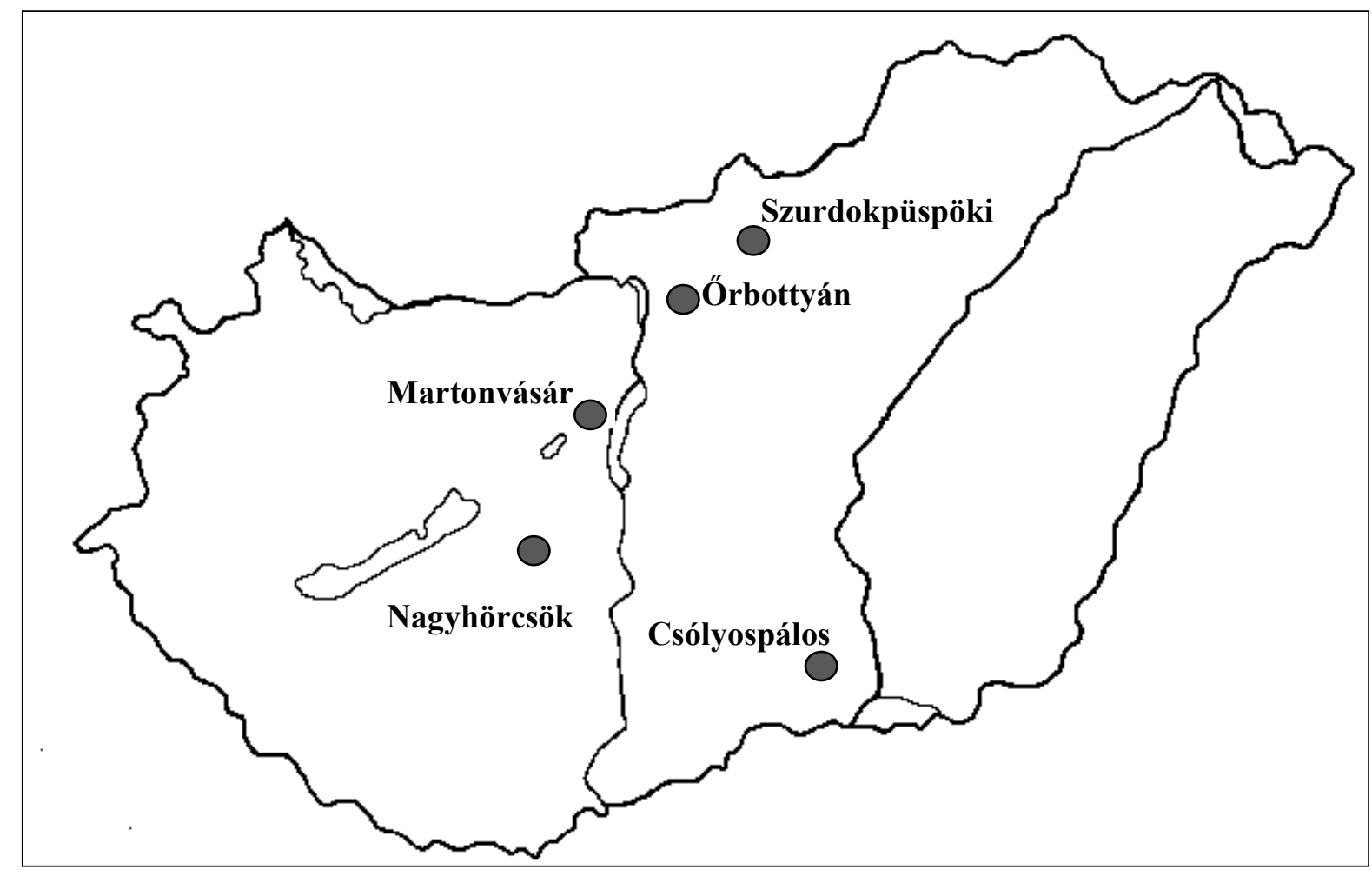

2. ábra: A mintaterületek elhelyezkedése.

\subsection{1. Őrbottyáni mintaterület}

A mintaterület a Pesti-síkság és a Gödöllői-dombság találkozásánál helyezkedik el, mely következtében a terület talajtulajdonságait tekintve rendkívül változatos. A vizsgálatokat az MTA ATK Talajtani és Agrokémiai Intézet telephelyén (3. ábra) végeztük el, mely területen korábban is számos vizsgálat folyt (Németh és Buzás, 1991; Németh, 1995; Szili-Kovács et al., 2009; Kádár et al., 2012).

Örbottyánban két mintaterületen végeztünk kísérleteket 2009 és 2013 között (3. ábra). A területen feltárt talajszelvény leírása az 1. mellékletben olvasható. A kísérleti területekről 3 ismétlésben vett bolygatott talajminták, 3 frakciós mechanikai összetétel vizsgálata alapján, mind a két területen homoktalaj található, mely átlagos talajjellemzői: homok frakció: 86,3\%, vályog-: 8,3\%, agyag-: 5,4\%, humusztartalom: 0,91\%. A vizsgált terület átlagos mész tartalma 2,65 \%, melyek alapján, a terület talaja közepes humusztartalmú, gyengén meszes 
homok. A mintaterületeken végzett vizsgálatok részletes leírása a 2-6. mellékletekben olvasható.

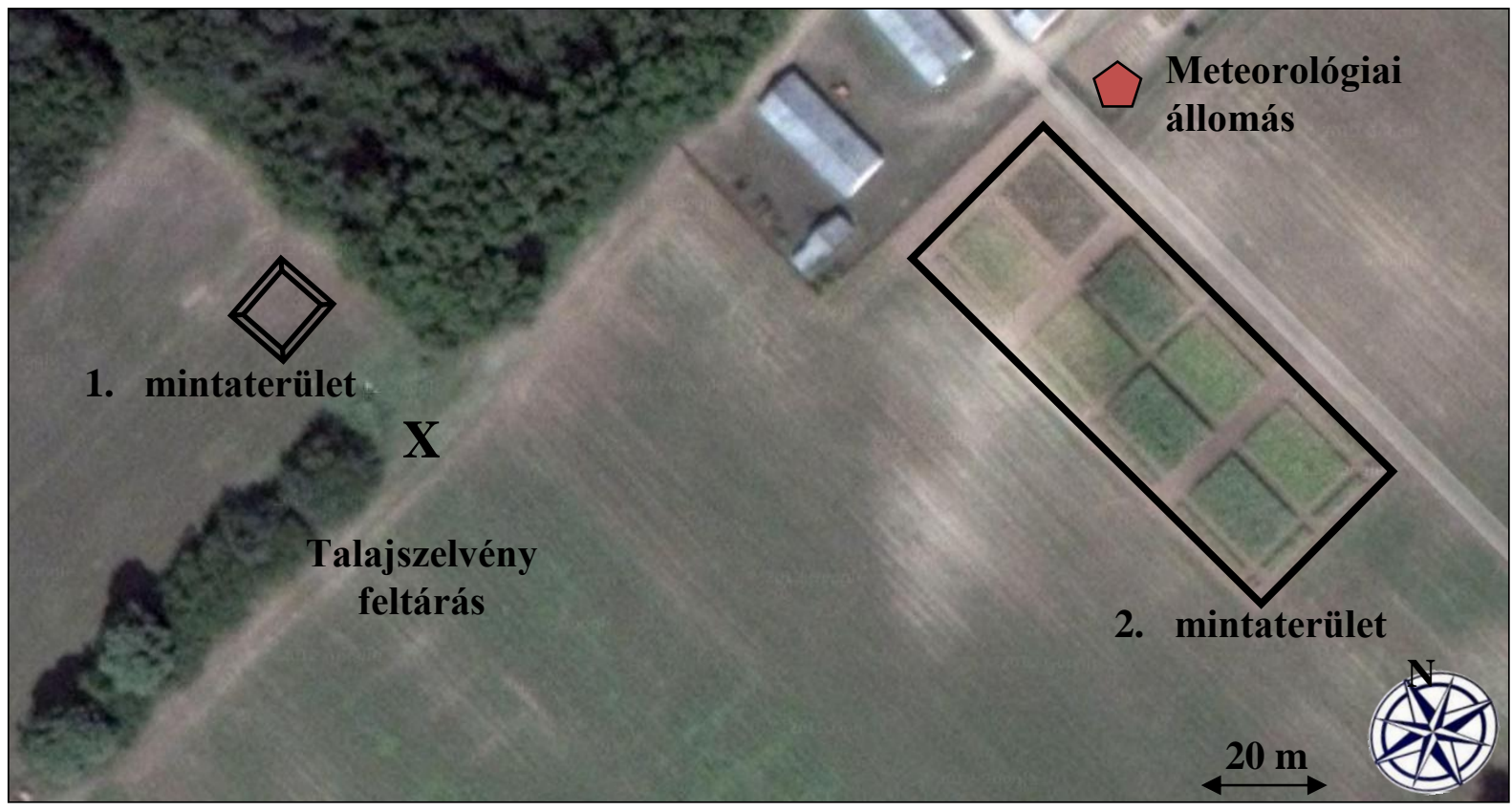

3. ábra: Az örbottyáni mintaterület. (Müholdkép forrása: https://maps.google.hu/ )

Az 1. mintaterületet (GPS 47,673; 19,245) korábban szántóként (pillangósok, rozs) hasznosították. Mủvelésével 2005-ben hagytak fel. A terület sík helyzetü, körülötte erdei fenyves (Pinus Sylvestris) található. Vizsgálatainkat 2010 és 2013 között végeztük el, melyek során megmértük a feltalaj (0-10 cm-es réteg) telítési vízvezető képesség, $\mathrm{pF}$, víztaszítás és térfogattömeg értékeinek térbeli heterogenitását és időbeli változékonyságát több ismétlésben.

A 2. mintaterületen (GPS 47,672; 19,249) kisparcellás szabadföldi kísérletet állítottunk be, mely $8 \mathrm{db} 10 \times 15 \mathrm{~m}$-es parcellái a szegélyekkel együtt $30 \times 80 \mathrm{~m}\left(2400 \mathrm{~m}^{2}\right)$-es területen helyezkednek el, ahol 2010 és 2012 között monokultúrás kukoricatermesztés folyt. A három év 4 kezelése két ismétlésben: kontroll, öntözött, mütrágyázott, illetve öntözött és mütrágyázott volt (4. ábra). Az agrotechnika részletes bemutatása a 7. mellékletben olvasható. A kísérlet indulásakor - 2010. április 16-án - minden parcellán három ismétlésben, 0-30, 30-60 és 60-90 cm-es mélységekböl bolygatatlan és bolygatott mintákat vettünk teljeskörü talajfizikai és -kémiai feltárásra (ld.: 3. és 4. melléklet). Az így megállapított bemenő adatokat és paramétereket felhasználtuk a talaj modellben történő definiálására.

A talaj-növény-légkör rendszer folyamatainak napi léptékü szimulációs modellezéséhez szükséges bemenő adatokat folyamatosan rögzítettük az őrbottyáni 2 . mintaterületen. A mérések részletei (pl. az idő- és térbeli felbontás) a 6.2-es fejezetben olvashatók. 


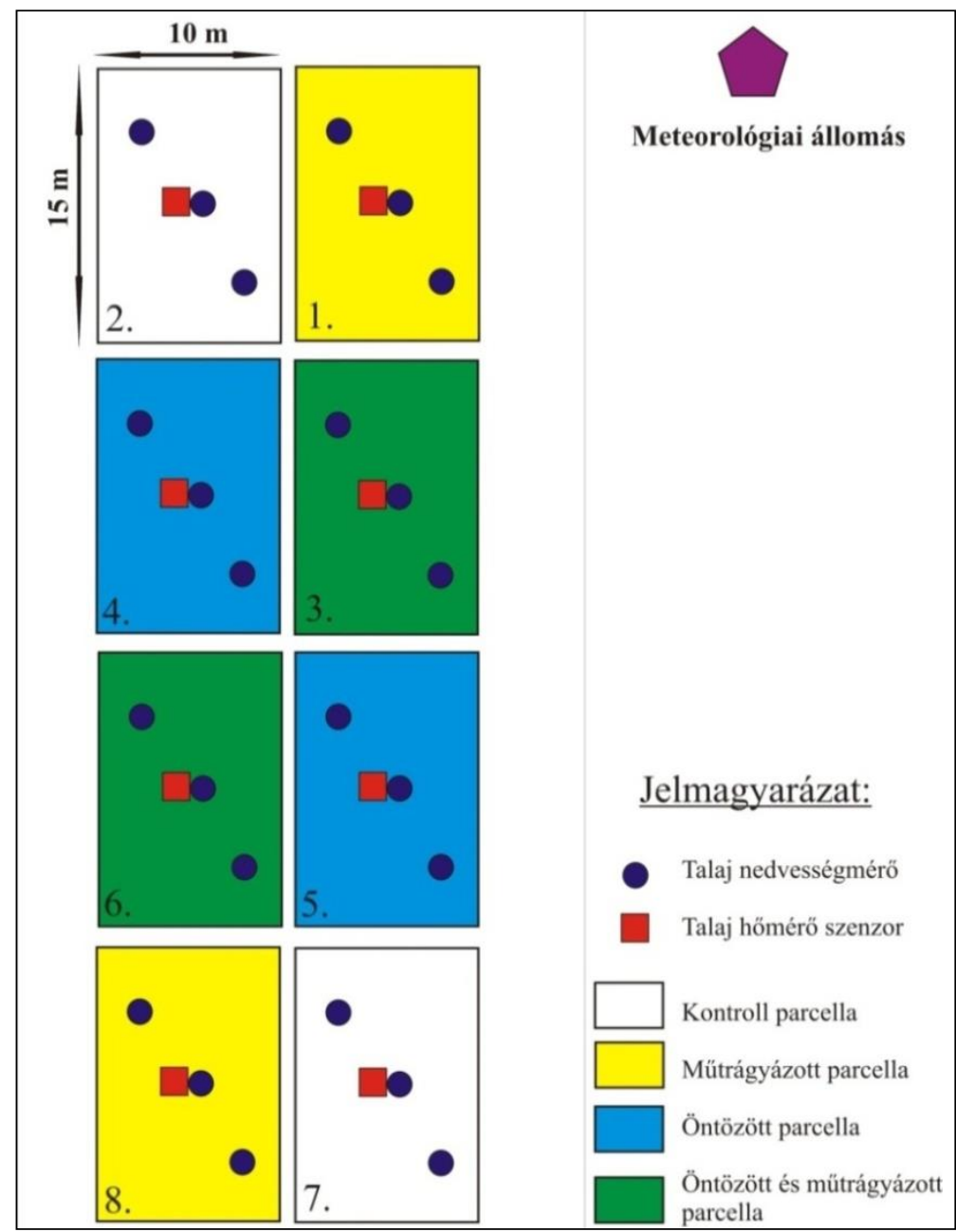

4. ábra: Az örbottyáni kisparcellás szabadföldi kísérlet grafikus ábrázolása (2. mintaterület).

\subsubsection{Csólyospálosi mintaterület}

Csólyospálos a Dorozsma-Majsai-homokháton helyezkedik el, mely a Duna-Tisza közi síkvidék középtáj része. A kistáj felszíne enyhén hullámos, melynek alacsonyabb területein szikesek, illetve mésziszapos laposok alakultak ki, illetve helyenként a semlyékekben réti mészkő $\left[\mathrm{MgCa}\left(\mathrm{CO}_{3}\right)_{2}\right]$ felhalmozódása (Molnár, 1991) is történt. Csólyospálos területén a lepelhomok sok helyen elfedi a réti dolomitot, amely átlagosan 1-2 m-es mélységben megtalálható, és magyarázatot ad a talaj magasabb Mg és Ca tartalmára. Talaját tekintve az őrbottyánihoz hasonlóan humuszos homok, mely átlagos homoktartalma 95 \%, iszaptartalma: 2,6 \% és agyagtartalma: 2,4 \% (ld.: 5. melléklet). A mintaterület A szintjében mért átlagos humusz tartalom: 1,62 \%, pH: 8,1 és $\mathrm{CaCO}_{3}$ tartalom: 3,15\% volt, melyek alapján a csólyospálosi terület talaja jó humusztartalmú, gyengén meszes, homok (Novák, 2013). A mintaterület szelvényleírása a 8 . mellékletben olvasható.

A vizsgált terület Csólyospálos határában helyezkedett el (GPS 46,396; 19,819), mely 20 éve müveletlen. Korábban öszibarackos volt, melynek tönkjei helyenként még megtalálhatók. Vizsgálatainkat 2011-2012-ben végeztük el, mely során megmértük a feltalaj 
(0-10 cm-es réteg) víztartóképesség-függvényének jellegzetes pF-pontjait (ld.: 7.1.), telítési vízvezető képességét és víztaszítás értékeinek térbeli heterogenitását és időbeli változékonyságát több ismétlésben is, mely módszerek bemutatása a 6.3.1. és 6.3.2-es fejezetekben leírtak szerint történtek.

\subsubsection{Martonvásári mintaterület}

Martonvásár a Mezőföld középtáj része, ezen belül a mintaterület a Váli-víz síkján helyezkedik el. A kistáj jellemzően löszös alapkőzetű (Dövényi, 2010). A terület jelentős részén jó termőképességü mészlepedékes csernozjom talajok fejlődtek ki. A vizsgálatainkat az MTA ATK Mezőgazdasági Intézetének telephelyén (GPS 46,396; 19,820) végeztük el 2011ben.

Megvizsgáltuk a mintaterület A szintjének mechanikai összetételét, mely szerint az átlagos homoktartalom 51,4\%, iszap: 34,0 \%, agyag: 14,6\%, mely alapján, a területen vályog talaj található (ld.: 5. melléklet). A vizsgálati terület feltalajának átlagos humusztartalma 2,85 \% volt. A martonvásári mintaterület szelvényleírása a 9. mellékletben olvasható. Megmértük a feltalaj (0-10 cm-es réteg) víztartóképesség-függvényének jellegzetes pF-pontjait (ld.: 7.1.), továbbá a térfogattömeg és telítési vízvezető képesség értékek időbeli változékonyságát is (ld.: 6.3.1 és 6.3.2-es. fejezetek).

\subsubsection{Nagyhörcsöki mintaterület}

A vizsgált terület a Káloz-Igari-löszhátak kistáj része, mely a Mezőföld középtájon belül helyezkedik el. A terület alapkőzete jellemzően lösz (Dövényi, 2010). A vizsgálatainkat az MTA ATK Talajtani és Agrokémiai Intézetének nagyhörcsöki telephelyén végeztük el 2009ben. A kísérleti terület (GPS 46,865; 18,518) talaja löszön kialakult típusos mészlepedékes csernozjomtalaj, mely szelvényleírása a 10. mellékletben található.

A vizsgálataink során megmértük 0-10 cm-es mélységben, 5 ismétlésben a területre jellemző telítési vízvezető képesség és a víztartóképesség-függvény jellegzetes pF-értékeit is, (ld.: 7.1.), továbbá az A szint térfogattömeg és mechanikai összetételének frakciónkénti eloszlását is rögzítettük ( $l d$. 5. melléklet). Méréseink alapján a mintaterület 0-30 cm-es szintjének átlagos homoktartalma $18,9 \%$, iszaptartalma 56,0 \%, agyagtartalma $25,1 \%$. Tehát a szemcseösszetétele alapján vályog talaj található a területen, mely feltalajának humusztartalma 3,45\%, mésztartalma 3,9\% (ld.: 6. fejezet). 


\subsubsection{Szurdokpüspöki mintaterület}

Szurdokpüspöki az Észak-Magyarországi-medencék középtájon belül a Zagyva-völgy kistájhoz tartozik. A terület talajainak jellemző mechanikai összetétele agyagos-vályog, illetve vályogos-agyag, mely a Cserhát és Mátra andezit-, andezittufa- és riolittufa málladékaiból alakult ki (Dövényi, 2010). A méréseinket a Szent István Egyetem meteorológiai és ökológiai mérőállomásának telephelyén (GPS 46.429; 20.234) végeztük el 2011-ben. A plató helyzetü mintaterületet az erdőség kivágása után szántóként hasznosították, mely müvelésével 25 éve felhagytak. Zárt gyep alakult ki, melyet 2004-ig legeltettek, azóta kaszálóként hasznosítják (Hagyó, 2009).

A szurdokpüspöki mintaterület A szintjében mértük a legmagasabb szervesanyagtartalmat, 4,37 \%-ot (ld. 6. melléklet). A vizsgált terület feltalajának átlagos mechanikai összetétele: 13,2 \% homok, 41,8 \% iszap és 45,0 \% agyag, mely alapján agyag fizikai féleségű (ld.: 5. melléklet) a mintaterület. A szurdokpüspöki talajszelvény leírása a 11 . mellékletben olvasható.

Megmértük a szurdokpüspöki mintaterület 0-10 $\mathrm{cm}$ közötti szintjének víztartóképesség-függvényének jellemző pF-pontjait (ld.: 7.1.), telítési vízvezető képesség és térfogattömeg értékeit (ld.: 6.3. fejezet).

\subsection{A VIZSGÁLT RENDSZERVÁLTOZÓK MEGHATÁROZÁSA}

A talaj-növény-légkör rendszer modellezése során szükség van bizonyos bemenő adatok és paraméterek megadására. Az adatrögzítés, illetve a mérés során is megjelenik a tér- és időbeli léptékfüggés, ezért fontos a modellezés során használt input adatok felvételezésének és a paraméterek mérésének egzakt leírása. A dolgozatban alkalmazott rendszerváltozók, azok mérési menete, illetve körülményei az alábbi pontokban részletes bemutatásra kerülnek.

\subsubsection{A bemenő adatok mérése}

\subsubsection{A meteorológiai adat-felvételezés}

Az örbottyáni 2. mintaterület tőszomszédságában felállítottunk egy meteorológiai állomást (3. és 4. ábra), mely 2010.03.31-óta folyamatosan szolgáltat adatokat. A léghőmérséklet, globálsugárzás, relatív páratartalom, szélsebesség és -irány, illetve csapadék mennyiségét 5 perces időközönként rögzíti a méröállomás adatgyüjtő egysége. A csapadék mérése egy automata billenőedényes csapadékmérővel történik, mely mérési felbontása 0,25 mm.

A csólyospálosi mintaterületen napi rendszerességgel történt a méröedényes csapadékmérés, a 6.3.1-es fejezetben bemutatott kísérlet ideje alatt. 
A martonvásári mintaterületen 2010-óta OMSZ meteorológiai állomás üzemel. Az így rögzítésre került napi léptékü csapadék adatokat használtuk fel a 6.3.1-es fejezetben bemutatott kísérlet során.

\subsubsection{A talajhömérséklet monitorozás}

A talajhőmérséklet mérő szondákat az őrbottyáni 2. mintaterület parcelláinak közepén helyeztük el (4. ábra) $5 \mathrm{~cm}, 10 \mathrm{~cm}, 20 \mathrm{~cm}, 40 \mathrm{~cm}$ és $60 \mathrm{~cm}$-es mélységekben. A mérések 2010. május 20-óta folyamatosak, mely során 15 perces (téli időszakban 30 perces) felbontásban rögzítjük az aktuális hőmérsékleti értékeket. Az általunk használt termisztor típusú talajhőmérő szenzor pontossága $\pm 0,5^{\circ} \mathrm{C}$, felbontása $0,1^{\circ} \mathrm{C}$.

\subsubsection{A talajnedvesség-tartalom meghatározás}

A 2. számú mintaterületen a parcellaátlók mentén 3 darab TACANAT típusú, speciális plexiből készült, vékony falú 1 méteres béléscsövet helyeztünk el a 4. ábrán látható módon. A talajnedvesség adatok felvételezését 0-80 cm között, $10 \mathrm{~cm}$-es felbontásban 7-10 napos rendszerességgel végeztük a vegetációs időszakok alatt, 2010. április 16-óta. Méréseinkhez az IMKO TRIME-FM3 típusú hordozható szondát alkalmaztuk, mely nagy pontossággal képes mérni a talaj térfogatszázalékos nedvességtartalmát. Az alkalmazott módszer TDR (Topp és Davis, 1985) mérési technikán alapuló, precíziós talaj-nedvességmérő eljárás. A műszer a talaj dielektromos állandóját méri (Rajkai, 1991), a szonda fejrészén elhelyezkedő, $10 \mathrm{~cm}$ hosszú fém elektródapár segítségével. Az elektróda egyik végéből egy nagyfrekvenciájú elektromágneses hullám indul el az elektróda mentén. Az elektromágneses hullám egy része az elektróda másik végén visszaverődik és visszatér a forráshoz. A hullám kibocsátása és visszaérkezése között eltelt időből kiszámítható a hullám terjedési sebessége, mely a szondát körülvevő talaj dielektromos állandójának függvénye, amely szoros kapcsolatban áll a nedvességtartalommal. A TDR módszer előnye, hogy a mérést a talajtípus csak csekély mértékben befolyásolja, így kalibrálása egyszerübb. A mérés pontossága $\pm 2 \mathrm{~V} \%$. A mért értékeket befolyásolja ugyan a talaj sótartalma és hömérséklete (Dalton és van Genuchten, 1986), de ennek ellenére ez a jelenleg ismert (speciális védőfelszerelés nélkül használható) legpontosabb és legelterjedtebb terepi mérési módszer.

\subsubsection{A növényi bemenö adatok meghatározása}

A vegetációs időszakokban (2010-2012) az őrbottyáni 2. mintaterületről parcellánként 3-5 kukorica növényt vettünk véletlenszerű mintavételezéssel, 3 hetes időközönként. A növények 
zöld- és abszolút száraz tömege, magassága mellett rögzítettük a levélfelület index értéket is, melyet Montgomery (1911) módszerével határoztuk meg (12. egyenlet).

$L A=L \times W \times A$

ahol LA: levélfelület $\left[\mathrm{cm}^{2}\right], \mathbf{L}$ : levél hossza $[\mathrm{cm}], \mathbf{W}$ : levél legnagyobb szélessége $[\mathrm{cm}], \mathbf{A}$ : konstans, értéke: 0.75 [-].

\subsubsection{A talaj hidrológiai paramétereinek mérése}

\subsubsection{A viztartó képesség}

A víztartóképesség-függvény $\mathbf{h}(\Theta)$ (soil water retention curve, SWRC) a talaj nedvességtartalma $(\Theta)$ és nedvességpotenciálja $(\mathrm{h})$ közötti összefüggést írja le. A talajban történő vízmozgás leírásához elengedhetetlen a víztartóképesség-függvény, továbbá a vízvezetőképesség-függvény (soil hydraulic conductivity function, SHCF) megadása, konduktív nedvességforgalmi modellek esetén (Fodor et al., 2011). A gyakorlatban azonban a folytonos víztartóképesség-függvény, pF mérésekből származó néhány pontja ismert, amelyek alapján, függvényillesztéssel állítható elő a víztartóképesség-függvény (van Genuchten, 1980).

A pF-görbe meghatározásához $100 \mathrm{~cm}^{3}$-es bolygatatlan mintákat vettünk Eijkelkamp talajmintavevő segítségével 5-10 cm-es mélységből, mind az 5 kísérleti területről 5 ismétlésben. A legfelső 2-3 cm vastagságú réteg eltávolításával a gyökerek és az elhalt növényi maradványok módosító hatását igyekeztünk csökkenteni. Az őrbottyáni 2. mintaterület esetében a 35-40 és 65-70 cm-es mélységekre is meghatároztuk a jellegzetes $\mathrm{pF}$ értékeknek ( $\mathrm{pF}=0,0 ; 0,4 ; 1,0 ; 1,5 ; 2,0 ; 2,3 ; 2,7 ; 3,4 ; 4,2)$ megfelelő talajnedvesség-tartalmakat (ld.: 4. melléklet) a Várallyay-eljárás (Várallyay, 1978, 1987) alkalmazásával. A mért pFértékek mintaterületenkénti átlagára a TALAJTANonc 1.0 program (Fodor és Rajkai, 2005) segítségével 3 paraméteres van Genuchten-függvényt (1980) illesztettünk. Az így kapott paramétereket (ld.: 7.1-es fejezet: 3. táblázat), használtuk a Mini Disk Infiltrométeres mérések kiértékeléséhez is (ld.: 7.2.).

\subsubsection{A telitési vízvezetö képesség meghatározása}

A talaj hidraulikus vezetőképessége fontos bemenő paramétere mind a HYDRUS-1D, mind pedig a 4Mx modelleknek, ezért különböző laboratóriumi és terepi mérési módszerekkel határoztuk meg a mintaterületekre vonatkozó értékét. 


\section{A laboratóriumi $K_{S}$ meghatározási eljárások:}

(a.) A kispatronos, $100 \mathrm{~cm}^{3}$-es minták esetében a talaj telítési vízvezető képességét csökkenő vízoszlop módszerével (Várallyay, 1973a) határoztuk meg.

A méréshez 5-10 cm-es mélységböl bolygatatlan mintákat vettünk Eijkelkamp talajmintázó segítségével 5 ismétlésben a csólyospálosi, őrbottyáni, szurdokpüspöki és nagyhörcsöki mintaterületekről.

(b.) A Booltink-féle (Booltink et al., 1991) nagypatronos minták estében a talaj telítési vízvezető képességét az állandó vízoszlop módszerével határoztuk meg.

5 ismétlésben vettünk bolygatatlan mintákat 1-19 cm-es mélységböl a szurdokpüspöki, nagyhörcsöki és őrbottyáni mintaterületekröl. A mintavétel során a $6280 \mathrm{~cm}^{3}$-es és $20 \mathrm{~cm}$ átmérőjü és magasságú, vékonyfalú acél mintázó hengereket egy traktor hidraulikus emelőjének segítségével (Fodor et al., 2011) nyomtuk a talajba, 19 cm mélyre. Így körülbelül $5650 \mathrm{~cm}^{3}$-es talajmintákat kaptunk.

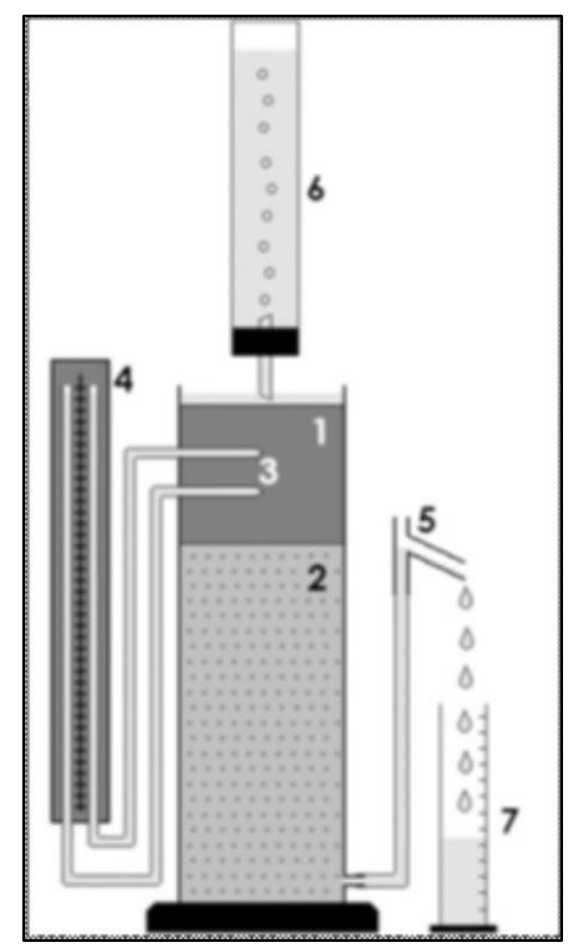

5. ábra: $\mathrm{K}_{\mathrm{S} \text {,makro }}$ mérése Fodor és munkatársai (2011) szerint. Jelmagyarázat: 1. talajminta; 2. kvarchomokkal töltött henger; 3. tenziométerek; 4. manométerek; 5. túlfolyó; 6. Mariott palack; 7. mérőhenger. (Ábra forrása:

Fodor et al., 2011)

A laboratóriumban a talajpatronokat $50 \mathrm{~cm}$ magas kvarchomokkal töltött hengerekre helyeztük - az 5. ábrán látható módon — és a csatlakozásnál szilikongéllel vízzáróvá tettük a rendszert. A hengert, majd a patront alulról lassan vízzel telítettük. A talaj telítettség állapotát a mintába helyezett tenziométerek segítségével ellenőriztük. A vízzel teljesen telítődött talajon átfolyási kísérletet hajtottunk végre egy Mariott palack segítségével (5. 
ábra). A talajminta vízszintjét a felszín alatt $20 \mathrm{~cm}$-rel állítottuk be, és méröhengerben felfogtuk az átfolyó vizet. A minta keresztmetszetén egységnyi idő alatt áthaladó víz mennyiségének ismeretében a Darcy-egyenlet (1856) segítségével kiszámítottuk a talaj telítési vízvezető képességét.

\section{$\underline{\text { A terepi } K_{S}} \underline{\text { mérési módszerek: }}$}

(a.) A Guelph permeaméter segítségével a $\mathrm{K}_{\mathrm{fs}}-\mathrm{t}$ határozhatjuk meg (Reynolds és Elrick, 1986). Guelph permeamétert azért alkalmaztuk, mert a mérés könnyen kivitelezhető, nem kíván terepi előkészítést. A készülékkel 15-75 cm-es mélységtartományban mérhetünk telítésközeli hidraulikus vezetőképesség értékeket, de a furat mélyítésével, illetve a szár meghosszabbításával akár több méteres mélységbe is lehatolhatunk és mérhetünk. Hátránya viszont, hogy igen költséges berendezés, ezért Magyarországon kevésbé ismert mérőmüszer.

Az őrbottyáni mintaterületen 5 ismétlésben mértük meg a talaj telítésközeli vízvezető képességét 10-15 cm-es mélységben Guelph permeaméter segítségével (1. kép).

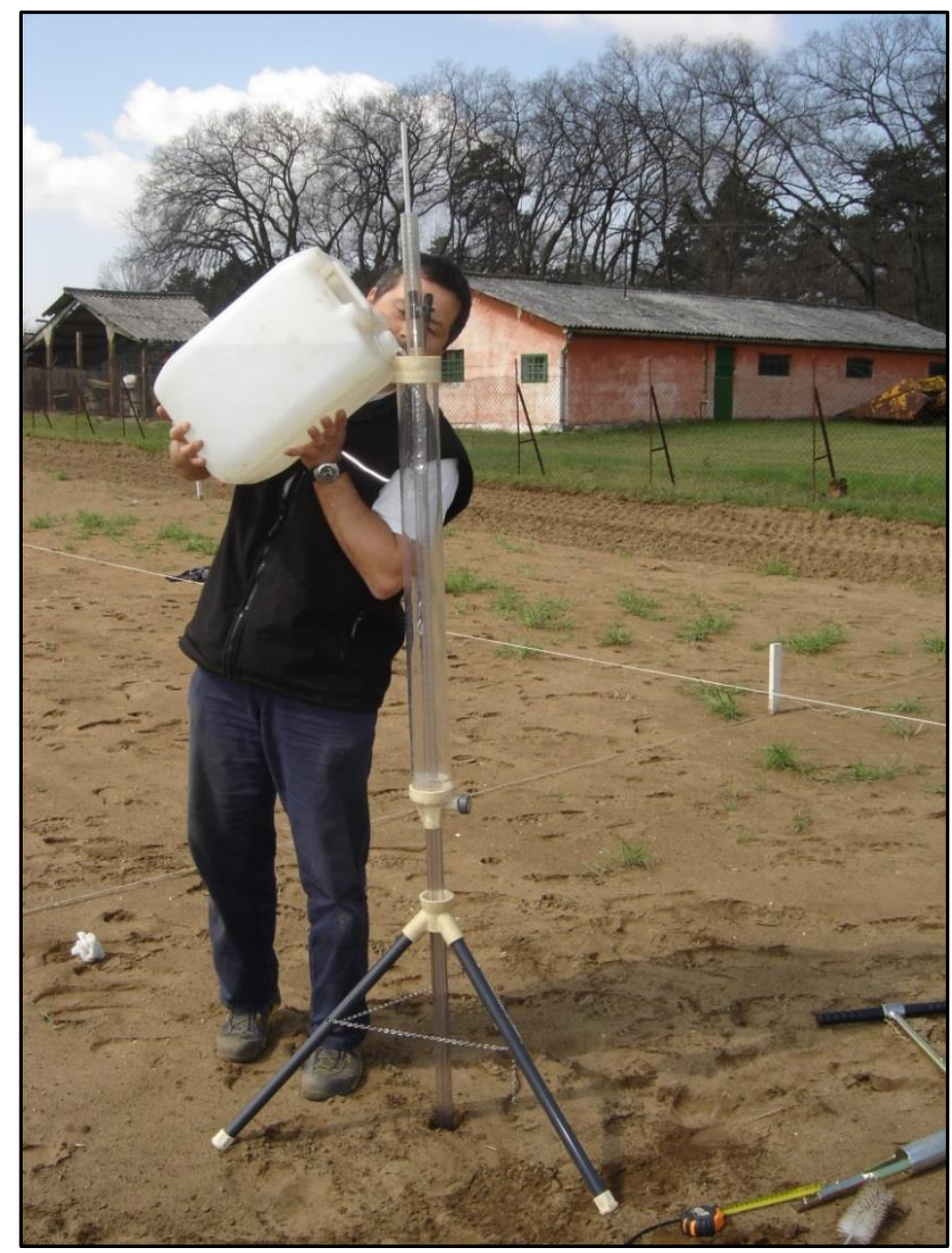

1. kép: A Guelph permeaméter feltöltése vízzel. Örbottyán, 2010. (Saját felvétel) 
A mérés során egy $6 \mathrm{~cm}$ átméröjű furatot hoztunk létre, melyben mm skálával ellátott Mariott palack segítségével először 5, majd $10 \mathrm{~cm}$-es vízoszlopot hoztunk létre. A palackból időegység alatt eltávozó víz mennyiségét mm-ben lejegyeztük, melyből Reynolds és Elrick (1986) módszerével meghatároztuk a talaj telítésközeli vízvezető képességét (13. egyenlet).

$K_{f s}=\left[0,0041 \cdot X \cdot R_{2}\right]-\left[0,0054 \cdot X \cdot R_{1}\right]$

ahol $\mathbf{K}_{\mathbf{f s}}$ : telítésközeli vízvezető képesség $\left[\mathrm{ms}^{-1}\right] ; \mathbf{X}$ : Mariott palack átmérője $[\mathrm{m}] ; \mathbf{R}_{\mathbf{1}}$ és $\mathbf{R}_{\mathbf{2}}$ : víz beszivárgási sebessége $\left[\mathrm{ms}^{-1}\right]$ eltérő vízoszlop magasságok esetén. A képletben szereplő két paraméter dimenziója $\mathrm{m}^{-1}$.

(b.) A Tension Disc Infiltrométer (TDI) (Wooding, 1968; Jarvis et al., 2002) használatával a talaj $\mathrm{K}_{\mathrm{fs}}$ értékét határoztuk meg az őrbottyáni mintaterületen. A TDI-t azért alkalmaztuk, mert viszonylag nagy felületen méri a $\mathrm{K}_{\mathrm{fs}} \mathrm{t}$ a méröberendezés.

A mérés során a víz egy szitaszövettel bevont $20 \mathrm{~cm}$ átmérőjü perforált plexikorongon keresztül áramlik a talajba, mely felszínét egyenletesen bevontunk kvarchomokkal, a teljes felületủ érintkezés érdekében. A módszer hátránya, hogy szeles időben nehéz biztosítani a beszivárgási felület állandóságát, továbbá a mérési terület előkészítése, szintezése is kívánatos. A készülék költséges és kezelése körülményes. A beszivárgásmérővel legalább két szívóerő értékhez ( $\mathbf{h}_{\mathbf{1}}$ és $\mathbf{h}_{2}$ ) tartozó, egységnyi idő alatt a talajba szivárgó víz mennyiségének $\left(\mathbf{Q}_{1}\right.$ és $\left.\mathbf{Q}_{2}\right)$ meghatározása szükséges (Rajkai, 2004). Ezek ismeretében a Wooding (1968) összefüggés (14. egyenlet) $\boldsymbol{\alpha}$ és $\mathbf{K}_{\mathbf{f s}}$ ismeretlenje meghatározható (18. és 19. egyenlet).

$Q=\pi r^{2} K_{f s}\left[1+\frac{4}{\pi r \alpha}\right]$

Amennyiben kombináljuk a Wooding-egyenletet [14] a Gardner (1958) féle vízvezetőképesség-összefüggéssel [15]

$K\left(h_{1}\right)=K_{f s} \exp \left(\alpha h_{1}\right)$

és felírjuk a két nedvességpotenciálra a következő két egyenletet:

$Q\left(h_{1}\right)=\pi r^{2} K_{f s} \exp \left(\alpha h_{1}\right)\left[1+\frac{4}{\pi r \alpha}\right]$ 
$Q\left(h_{2}\right)=\pi r^{2} K_{f S} \exp \left(\alpha h_{2}\right)\left[1+\frac{4}{\pi r \alpha}\right]$

akkor az 16. és 17. egyenlet hányadosából kifejezhető az $\alpha$ :

$\alpha=\frac{\ln \left[\frac{Q\left(h_{2}\right)}{Q\left(h_{1}\right)}\right]}{h_{2}-h_{1}}$

Az alfára kapott kifejezést a 16. egyenletbe helyettesítve megkapjuk $\mathrm{K}_{\mathrm{fs}}$ értékét:

$$
K_{f S}=\frac{Q\left(h_{1}\right)}{\pi r^{2} \exp \left[\ln \left[\frac{Q\left(h_{2}\right)}{Q\left(h_{1}\right)}\right] /\left(h_{2}-h_{1}\right) \cdot h_{1}\right] \cdot\left[1+\frac{4}{\pi r \cdot \ln \left[\frac{Q\left(h_{2}\right)}{Q\left(h_{1}\right)}\right] /\left(h_{2}-h_{1}\right)}\right]}
$$

ahol $\mathbf{K}_{\mathbf{f s}}$ : a vízzel telített talaj vízvezető képessége $\left[\mathrm{ms}^{-1}\right] ; \mathbf{h}_{\mathbf{1}}$ és $\mathbf{h}_{\mathbf{2}}$ : szívóerők, amelyeken a beszivárgás végbemegy $[\mathrm{m}] ; \mathbf{Q}$ : a talajba adott idő alatt beszivárgó vízmennyiség $\left[\mathrm{m}^{3} \mathrm{~s}^{-1}\right] ; \mathbf{r}$ : beszivárgási felület sugara $[\mathrm{m}]$; $\boldsymbol{\alpha}$ : müszer állandó $\left[\mathrm{m}^{-1}\right]$.

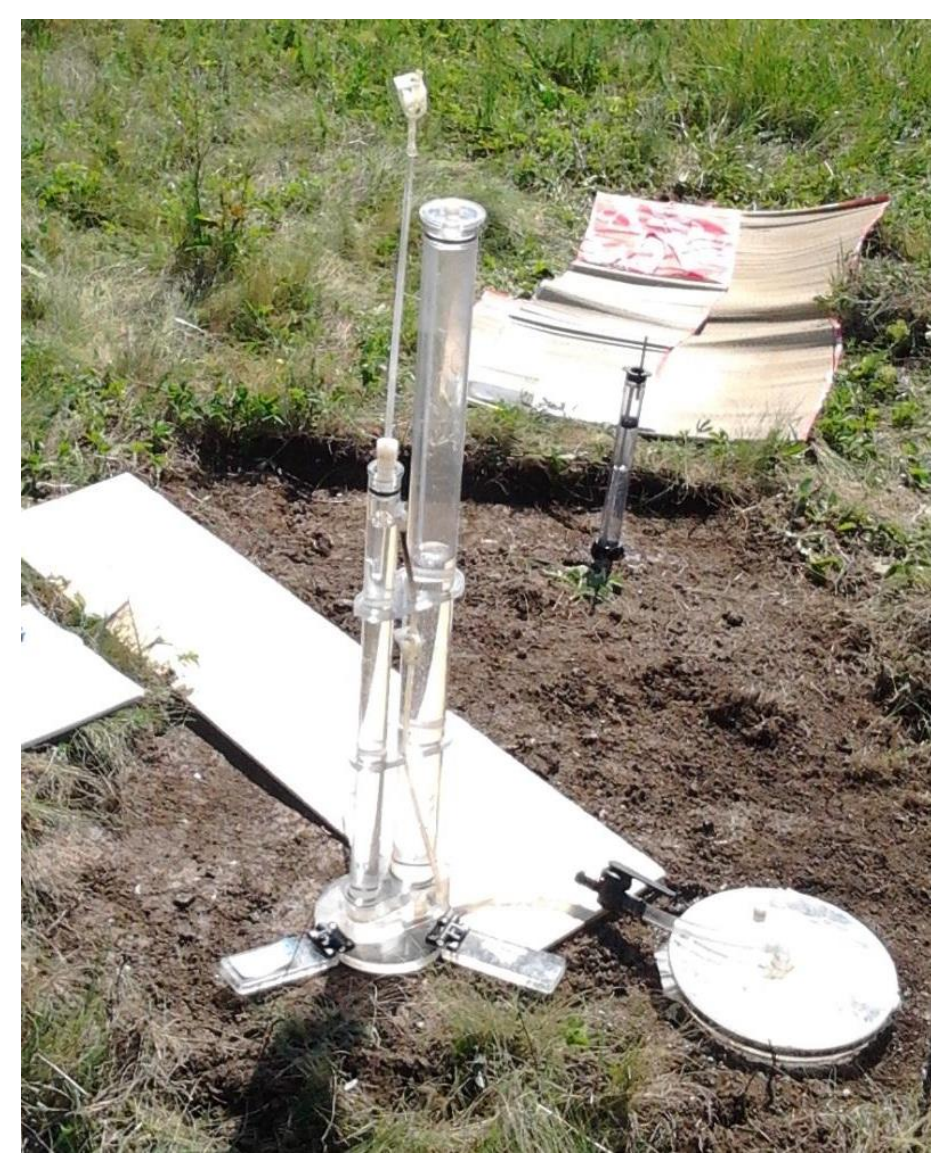

2. kép: Tension Disc Infiltrométer mérés közben, a háttérben Mini Disk Infiltrométeres mérés. Szurdokpüspöki, 2011. (Saját felvétel) 
(c.) A minikorongos beszivárgásmérőnek is nevezett Mini Disk Infiltrométert (MDI) (Decagon, 2010) (3. kép) alkalmaztuk Csólyospálos, Martonvásár, Nagyhörcsök, Örbottyán és Szurdokpüspöki területén, ahol méréseinket minimum 5 ismétlésben végeztük el. Azért alkalmaztuk ezt a módszert, mert a müszer olcsó, könnyen kezelhető, kis mérete miatt egy méréshez mintegy $135 \mathrm{~cm}^{3}$ víz elegendő. Továbbá Hunter és munkatársai (2011) bizonyították, hogy a Mini Disk Infiltorméterrel mért vízvezető képesség értékek szignifikánsan nem különböznek a világszerte ismert és alkalmazott Tension Disc Infiltrométerrel kapott eredményektől, illetve, hogy víztaszító talajok esetében is alkalmazható.

A mérésekkel a $\mathrm{K}_{\mathrm{fs}}$ értékét határoztuk meg $2 \mathrm{~cm}_{\mathrm{H} 2 \mathrm{O}}$ szívóerő mellett, melyet egy szabályzó cső segítségével (6. ábra) állítottunk be. A szurdokpüspöki agyag talaj esetében, a kisebb áteresztőképesség miatt, ezt $0,5 \mathrm{~cm}$-re módosítottuk. A mérömüszer egy $4,5 \mathrm{~cm}$ átmérőjü, $0,5 \mathrm{~cm}$ vastag szinterezett fémporból sajtolt porózus korongon keresztül érintkezik a talajjal. A mérés során a talaj, az adott szívóerő függvényében vizet vesz fel, így vízszintcsökkenés jelentkezik és vákuum keletkezik a folyadék tárolóban, mely hatása továbbítódik a buborék kamrába a Mariott csövön keresztül. Ennek hatására levegő lép be először a buborék kamrába, majd a Mariott cső közvetítésével eljut a folyadék tárolóba, ahol kiegyenlítődik a nyomás és a talaj újból vizet vesz fel. A mérés során az egységnyi idő alatt tapasztalható vízszintcsökkenést jegyeztük le.

A K $\mathrm{sf}_{\mathrm{s}}$ kiszámításához Zhang (1997) módszerét alkalmaztuk:

$Q=\mathbf{C}_{1} t+\mathbf{C}_{2} \sqrt{t}$

ahol Q: a talajba adott idő alatt beszivárgó vízmennyiség $\left[\mathrm{m}^{3} \mathrm{~s}^{-1}\right] ; \mathbf{C}_{\mathbf{1}}\left(\mathrm{m}^{3} \mathrm{~s}^{-2}\right)$ és $\mathbf{C}_{\mathbf{2}}\left(\mathrm{m}^{3} \mathrm{~s}^{-1,5}\right)$ paraméterek. $\mathbf{C}_{\mathbf{1}}$ a vízvezető képességgel áll összefüggésben, a $\mathbf{C}_{\mathbf{2}}$ a talaj szorpcióval. A talaj vízvezető képességét $\left(\mathrm{K}_{\mathrm{fs}}\right)$ a következőképp kapjuk meg:

$$
K_{f s}=\frac{\mathrm{C}_{1}}{A}
$$

ahol $\boldsymbol{C}_{\boldsymbol{1}}$ : illesztési paraméter, amikor a gyök(t) függvényében ábrázolt kumulatív beszivárgási értékekre az [20] alakú függvényt illesztjük. Az A érték a van Genuchten paraméterekkel áll kapcsolatban, melyet a következő képletek definiálnak (Zhang, 1997): 
$A=\frac{11.5\left(\mathrm{n}^{0.1}-1\right) \exp \left[2.92(\mathrm{n}-1.9) \alpha \mathrm{h}_{0}\right]}{\left(\alpha \mathrm{r}_{0}\right)^{0.91}}$ $n \geq 1.9$

$A=\frac{11.65\left(\mathrm{n}^{0.1}-1\right) \exp \left[7.5(\mathrm{n}-1.9) \alpha \mathrm{h}_{0}\right]}{\left(\alpha \mathrm{r}_{0}\right)^{0.91}}$ $n<1.9$

ahol $\boldsymbol{n}$ és $\boldsymbol{\alpha}$ : a talaj víztartóképesség-függvényének van Genuchten paraméterei, $\boldsymbol{r}_{\boldsymbol{0}}$ : a korong sugara $(2,25 \mathrm{~cm})$; és $\boldsymbol{h}_{\boldsymbol{0}}$ a beállított szívóerő $(0,5$ vagy $2 \mathrm{~cm})$.

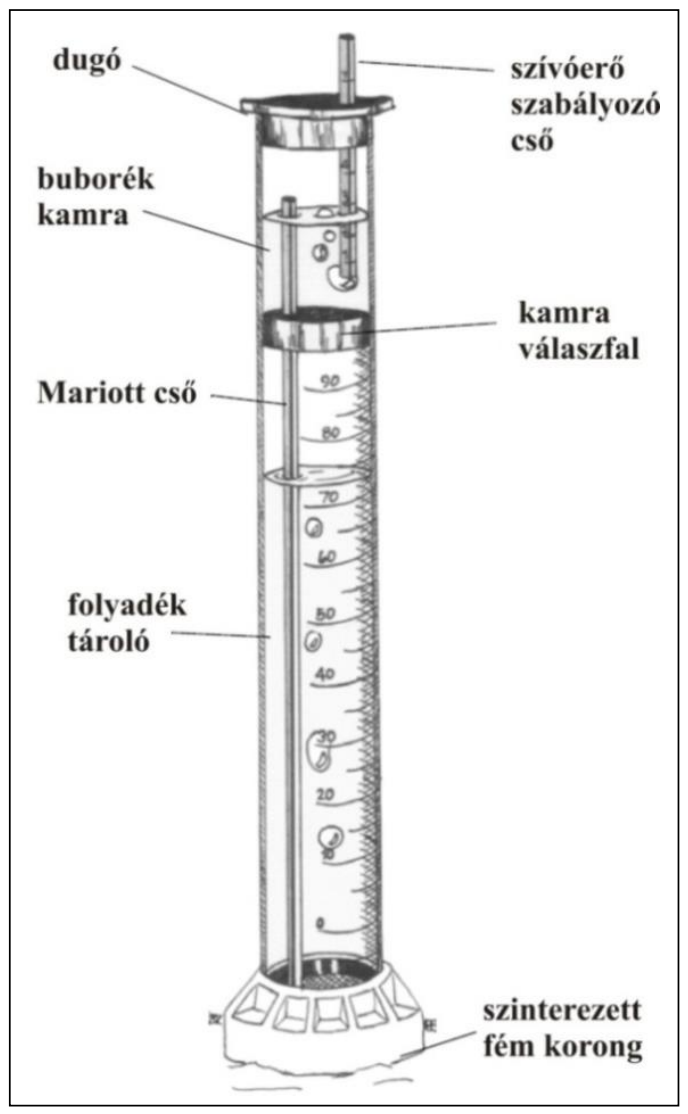

6. ábra: A Mini Disk Infiltrométer felépítése. (Ábra forrása: Decagon, 2010)

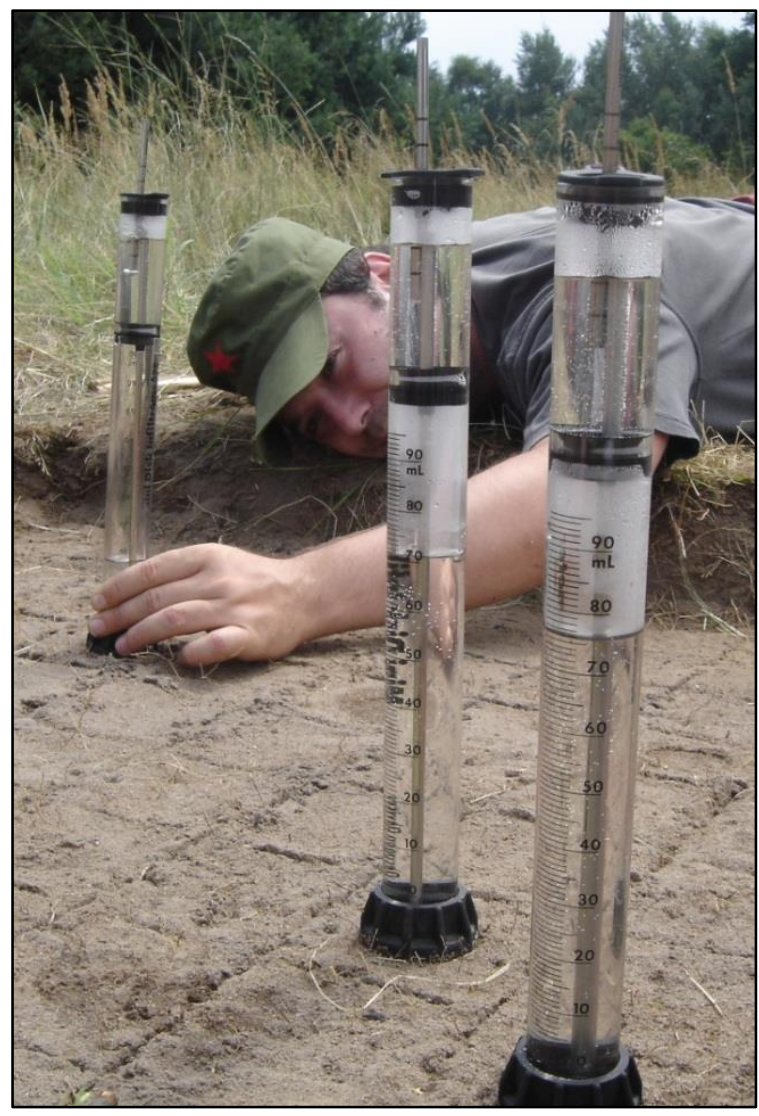

3. kép: MDI használat közben. (Saját felvétel)

Az MDI módszer hátránya (Fodor et al., 2009), hogy a kiértékeléshez szükség van a talaj mért víztartóképesség-értékeire illesztett van Genuchten-féle víztartóképesség-függvény (van Genuchten, 1980) $\boldsymbol{\alpha}$ és n paramétereinek értékére (Zhang, 1997) (ld.: 22. egyenlet), melyek méréssel történő megállapítása időigényes. Amennyiben nem rendelkezünk mérésből származó $\boldsymbol{\alpha}$ és $\boldsymbol{n}$ paraméter értékekkel, a meghatározásukhoz felhasználhatjuk Carsel és Parrish (1988) táblázatát (Decagon, 2010), melyben 12 talajtípusra megadták az átlagos paraméter értékeket. 


\subsubsection{A talajok víztaszításának vizsgálata}

A víz talajba szivárgását jelentősen befolyásolhatja, ha a talaj víztaszító tulajdonságú (ld.: 5.2.10. fejezet). A víztaszítás (vagy talajnedvesíthetőség) mértéke nagymértékben meghatározhatja a mért telítési vízvezető képesség értékét. Mivel a $\mathrm{K}_{\mathrm{S}}$ fontos paramétere a talajban történő vízmozgás leírásának, ezért elengedhetetlen, hogy megvizsgáljuk a talajnedvesíthetőséget, melyet a 6.2.3.1. fejezetben leírt módszerrel határoztunk meg. A szakirodalom szerint (Singer és Ugolini, 1976) a talajnedvesíthetőség mértéket befolyásolja a talaj szervesanyag mennyisége és minősége, ezért szükségszerünek láttuk a humuszfrakciók meghatározását is a hagyományos humusztartalom mérés mellett.

\subsubsection{A talajnedvesithetöség (talajok víztaszítása)}

A talaj nedvesíthetőségét - a világszerte egyre elterjedtebb - Water Drop Penetration Time (WDPT) vagyis vízcsepp beszivárgási idő mérésével vizsgáltuk (4. kép). A vizsgálat során a talaj felszínére pipetta segítségével elhelyezünk egy vízcseppet és mérjük a beszivárgásához szükséges időt, mely mértékéböl következtethetünk a talaj víztaszítására. Az mérések kiértékeléséhez Dekker és Ritsema (1996) skáláját alkalmaztuk, mely beosztása az 5.2.10-es fejezetben olvasható. Víztaszítás vizsgálatokat a csólyospálosi és őrbottyáni homoktalajokon végeztünk, mivel az előzetes vizsgálatok alapján a dolgozatban szereplö többi mintaterület jól nedvesíthető volt.

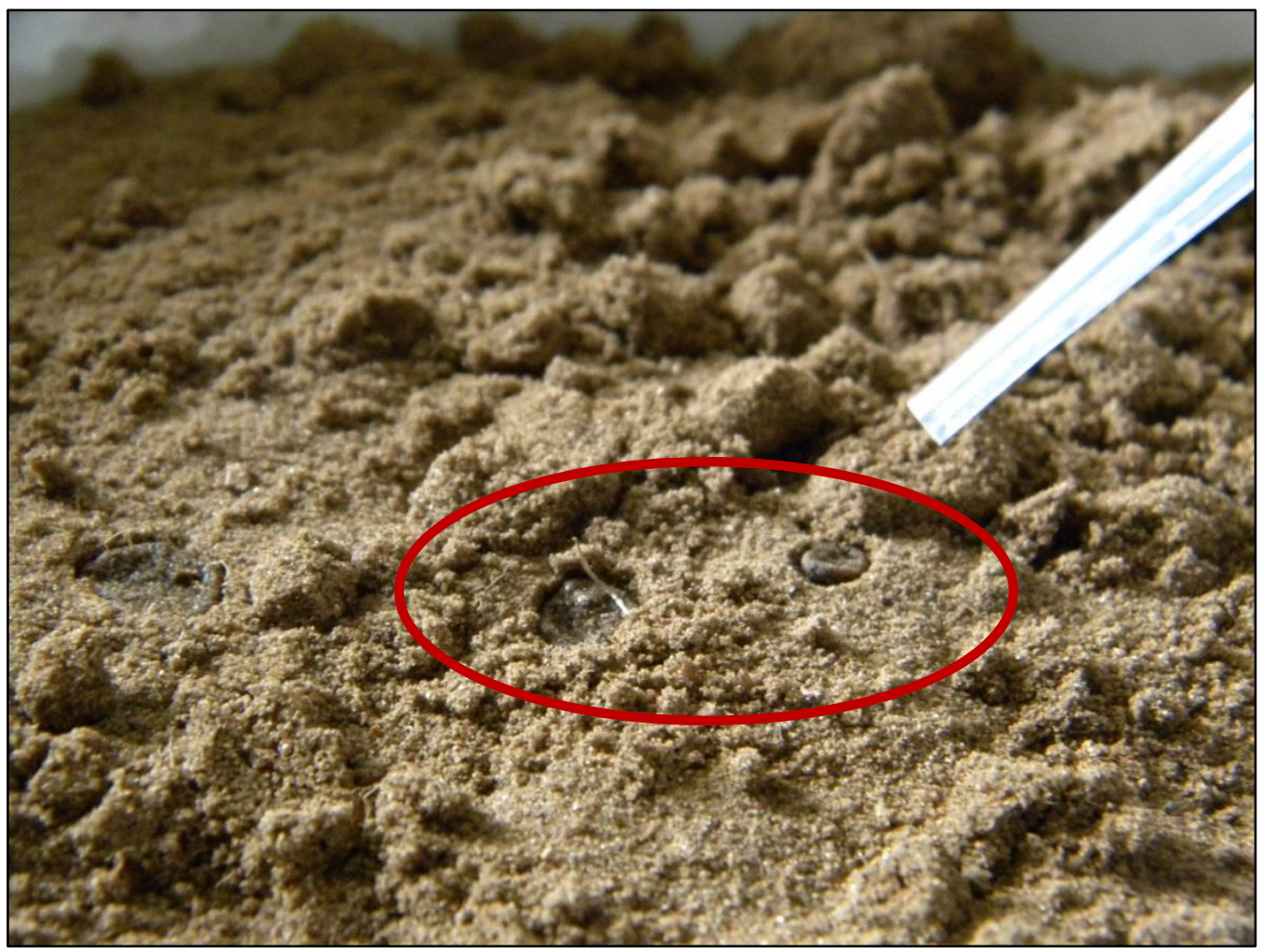

4. kép: Talaj nedvesíthetőség (WDPT) teszt homoktalajon. (Saját felvétel) 


\subsubsection{A talajok szervesanyagának és humuszfrakcióinak meghatározása}

Mivel a talaj nedvesíthetőségét jelentősen befolyásolja a szerves szén mennyisége, illetve minősége (Singer és Ugolini, 1976), ezért megmértük az őrbottyáni és csólyospálosi homoktalajok humusztartalmát a klasszikus Tyurin-módszerrel, továbbá a talajok huminsav/fulvosav arányát mint a talaj szervesanyagára jellemző minőségi paramétert, szintén Tyurin által kidolgozott eljárással (Buzás, 1988). A Tyurin-féle humusz meghatározás esetében, a szabvány szerinti $250 \mu \mathrm{m}$-es szitálást követően, $125 \mu \mathrm{m}$-es szitát használtunk, mivel szabad szemmel látható növényi részek maradtak a talajmintákban.

A humuszfrakciók meghatározását a következőképpen végeztük el: 2 g, $500 \mu \mathrm{m}$-es szitán átszitált, gyökérmaradványoktól megtisztított légszáraz talajt $0,5 \mathrm{M} \mathrm{NaOH} / 0,1 \mathrm{M}$ $\mathrm{Na}_{4} \mathrm{P}_{2} \mathrm{O}_{7}$ elegyével rázattuk 24 óráig 1:10 talajkivonószer aránnyal (Piccolo és Mirabella, 1987). A mintákat maradéktalanul leszürtük egy $50 \mathrm{~cm}^{3}$-es mérölombikba, majd desztillált víz kis mennyiségeivel addig mostuk át, míg a szürlet színtelenné vált. Ezután a mérőlombikot jelig töltöttük. A jól összerázott lombikot két kb. egyenlő részre osztottuk (A és B oldat), és a $\mathrm{pH}$ beállításával $(\mathrm{pH}$ 1) a szürlet egyik részletéből (B oldat) kicsaptuk a huminsavat. A fulvosav mennyisége a $B$ oldat szén-koncentrációjából adódik, míg a huminsav mennyisége az A oldat és a B oldat szénkoncentrációjának különbségéből számítható.

\subsection{HIDRAULIKUS TULAJDONSÁGOK IDÖ-, és TÉRBELI LÉPTÉKFÜGGÖ VIZSGÁLATA}

\subsubsection{A telítési vízvezető képesség időbeli változása}

Az időbeli változékonyság problémája a talajok visszatömörödésének vizsgálatán keresztül kerül bemutatásra az őrbottyáni (3. ábra: 1. mintaterület), csólyospálosi és martonvásári mintaterületeken. Vizsgálatainkat Örbottyánban 2011.04.18. - 2011.08.09., Csólyospáloson 2011.07.24. - 2011.10.14. és Martonvásárban 2011.06.07. - 2011.09.22. között végeztük el.

A mérésekhez egy $10 \times 2$ méteres területet a növénytakarótól megtisztítottunk, és gyomirtóztunk. 5-5 ismétlésben megmértük a talaj térfogattömegét, illetve hidraulikus vezető képességét Mini Disk Infiltrométerrel. A térfogattömeg mérésekhez bolygatatlan, $100 \mathrm{~cm}^{3}-\mathrm{es}$ mintákat vettünk a megtisztított talajfelszín felső $5 \mathrm{~cm}$-es rétegéből. Ezt követően rotációs kapa segítségével, a talaj felső $15 \mathrm{~cm}$-es rétegét fellazítottuk és a mủvelés után is megmértük talaj térfogattömegét és vízvezető képességét szintén 5-5 ismétlésben. A későbbiek folyamán minden nagyobb csapadékeseményt követően vízvezető képesség méréseket végeztünk a mintaterületen MDI-vel, illetve bolygatatlan mintákat vettünk térfogattömeg mérésekhez. A 
mért hidraulikus vezetőképesség és térfogattömeg értékeket a kumulált csapadék függvényében ábrázoltuk és grafikus módszerrel elemeztük.

\subsubsection{A hidraulikus tulajdonságok térbeli variabilitása}

A talajok térbeli heterogenitás vizsgálata során egy $1 \mathrm{~m}^{2}$-es területet $100 \mathrm{db} 10 \times 10$ cm-es cellára osztottunk fel Örbottyán (3. ábra: 1. mintaterület) és Csólyospálos kísérleti területein az 5. képen látható módon. Vizsgálatainkat Csólyospáloson 2012.05.03-án és Örbottyánban 2012.05.31-én végeztük el.

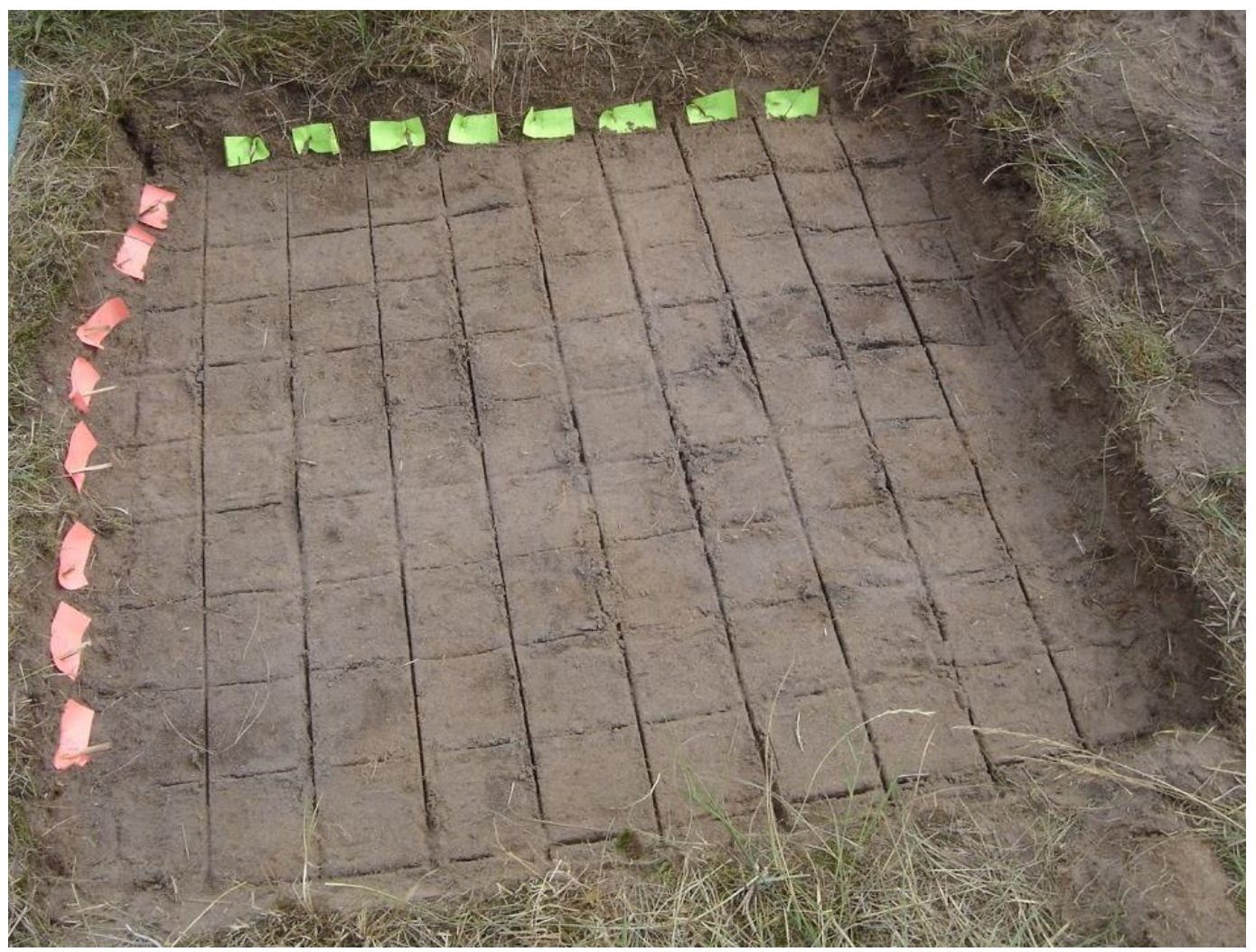

5. kép: Az $1 \mathrm{~m}^{2}$-es mintaterület felosztása, mint Csólyospáloson és Örbottyánon (Saját felvétel)

$\mathrm{Az} 1 \mathrm{~m}^{2}$-es terület mind a 100 cellájában a szisztematikus mintavételezést (systematic sampling) alkalmazva (Webster és Oliver, 1990) hidraulikus vezetöképesség mérést végeztünk MDI-vel, illetve megvizsgáltuk a talajnedvesíthetőséget. A $K_{S}$ méréséhez azért a Mini Disk Infiltrométert választottuk, mert Orfánus és munkatársai (2014) kimutatták, hogy a MDI esetében a kezdeti beszivárgási ütem független a talaj nedvességállapotától, így összehasonlítható a két mintaterületen végzett kísérlet. A talaj víztaszítását vízcsepp beszivárgási idő (Water Drop Penetration Time (WDPT)) mérésével vizsgáltuk, majd meghatároztuk minden egyes cella talajnedvesíthetőségi kategóriáját Dekker és Ritsema (1996) beosztása (ld.: 5.2.10.) szerint. A mért $\mathrm{K}_{\mathrm{S}}$ és talajnedvesíthetőség értékek kiértékelését T-próbával és grafikus módszerekkel elemeztük, továbbá meghatároztuk az eltérő mértékü víztaszítás hidraulikus vezetőképességre gyakorolt hatását. 


\subsubsection{A $K_{S}$ érték mintaméret-függése}

A talaj hidraulikus vezetőképességét többféle módon is mérhetjük, ill. becsülhetjük (ld.: 5.2.8.). Azonban az egyes módszerek különböző mérési, illetve mintavételezési egységekre vonatkoznak, melyek méretkülönbsége befolyásolhatja a mérni kívánt $\mathrm{K}_{\mathrm{S}}$ értékét. A terepi módszerek közül a TDI és az MDI is a $\mathrm{K}_{\mathrm{S} \text {,matrix }}$ értékét határozzák meg, azonban a TDI $20 \mathrm{~cm}$ átmérőjü, míg az MDI 4,5 cm átmérőjü beszivárgási felületen mér. Hunter és munkatársai (2011) kimutatták, hogy nincs szignifikáns különbség a két terepi módszer között. Azonban ilyen összehasonlítást még nem végeztek el a Várallyay-féle $100 \mathrm{~cm}^{3}$-es és az etalonnak számító Booltink-féle laboratóriumi eljárások között agyag talaj esetében. Fodor és munkatársai $(2009,2011)$ az örbottyáni és nagyhörcsöki mintaterületekről 5-5 ismétlésben vettek kis- és nagypatronos - 100 illetve $5650 \mathrm{~cm}^{3}$-es - mintákat. Ennek analógiájára történetek a szurdokpüspöki mintavételezések is, 2012.04.03-án. A mintavételezés során megvett $20 \mathrm{db}, 100 \mathrm{~cm}^{3}$-es mintából csak 10-et használtunk fel a kiértékeléshez, mivel a mintában növényi gyökérüregek maradtak vissza (6. kép). Ezek az üregek a makropórus áramlás felerősítésével jelentősen eltorzíthatják a mérési eredményt. A $\mathrm{K}_{\mathrm{S}}$ értékét a 6.2.2.2-es fejezetben leírtak szerint mértük meg. T-próbával vizsgáltuk meg, hogy szignifikáns különbség mutatkozik-e a mért $K_{S}$ értékekben, ha nagyságrendnyi különbség van a minták mérete között.

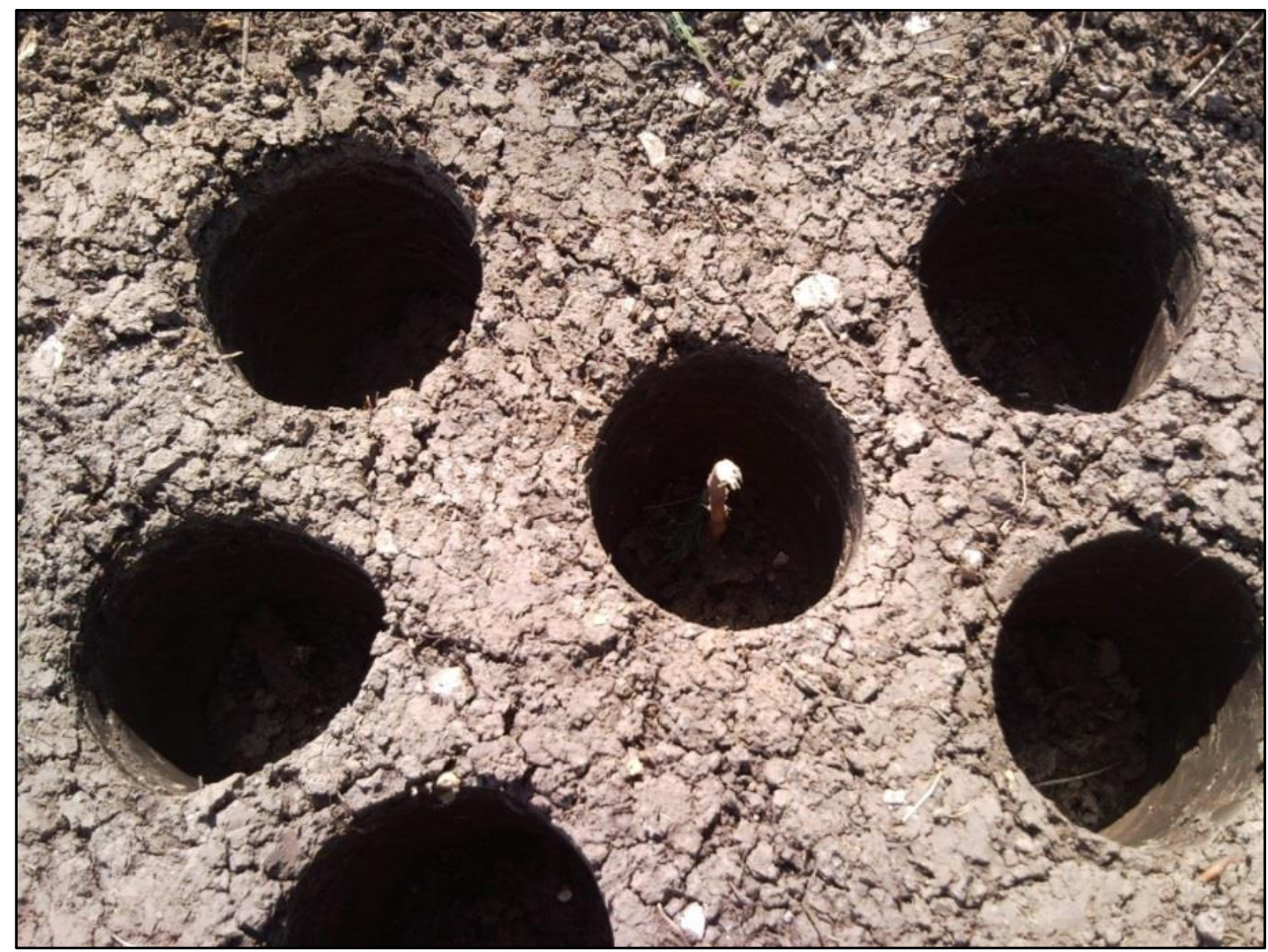

6. kép: Kispatronos, bolygatatlan mintavétel egy lehetséges hibaforrása, a mintában maradó gyökérüreg. Szurdokpüspöki, 2012.04.03. (Képet készítette: Radimszky László) 


\subsection{A LÉPTÉKFÜGGÉS MEGJELENÉSE a 4Mx és HYDRUS-1D MODELLEK}

ALKALMAZÁSA SORÁN

\subsection{1. $\quad 4 \mathrm{Mx}$ modell}

A 4Mx modell a bemenő talaj, időjárási, növényi és agrotechnikai adatok felhasználásával szimulálja a legmeghatározóbb talaj- és növényi folyamatokat. A 4Mx talaj modulján belül a nedvesség- és a hőforgalmat leíró almodulok befolyásolják legjelentősebben a modell kimeneti értékét, azaz ezek bemenő értékeire és paramétereire legérzékenyebb a modell, ezért a dolgozatomban ezen almodulok meghatározó folyamataival foglalkozom.

A modell beállítása során, — a modell felépítésének megfelelően —, meg kell adnunk az időjárási, növényi, talaj- és agrotechnikai adatokat. Az időjárási adatok esetén a modellezendő mintaterületen mért globálsugárzás, maximális és minimális hőmérséklet, csapadék, átlaghőmérséklet, relatív páratartalom és szélsebesség értékeket adtuk meg a modell számára bemenő adatként. A talajadatok megadásánál szintén a vizsgált területre vonatkozó mért adatainkat adtuk meg (pl.: térfogattömeg, maximális vízkapacitás, szabadföldi vízkapacitás, holtvíztartalom, $K_{S}$, humusz, NPK mennyisége). A növény modul a filokron intervallumot, a bázishőmérsékletet, a fenológiai fázisok hosszát és a szemtelítődés potenciális sebességét veszi figyelembe. Kezdő feltételként meg kell adni a víz és a tápelemek mennyiségét és ezek talajszelvényen belüli eloszlását, továbbá az agrotechnikai müveletek fajtájának és időpontjának jellemzőit, illetve a kijuttatott anyagok (pl. vetőmag) mennyiségét.

Modellezett növényként kukoricát állítottunk be, mivel 2010-2012 között kukorica növényt termeltük az örbottyáni 2. mintaterületen. Az agrotechnikai adatoknál a tényleges vetés, aratás, mütrágyázás és öntözés időpontjait, illetve mennyiségeit adtuk meg a modell számára (ld.: 7. melléklet). A modell részletes leírása az 5.1.1.2. fejezetben olvasható.

A 4Mx modell segítségével szimuláltuk az örbottyáni 2. mintaterületre vonatkozó léghőmérséklet értékek napi és kéthetes változását, a talajhőmérséklet értékek alakulását 5, 10, 20, 40 és 60 cm-es mélységekben, illetve a beszivárgás és talajpárolgás dinamikáját.

\subsubsection{HYDRUS-1D modell}

A vízgazdálkodási modellek közül azért a HYDRUS-1D modellt választottuk a vizsgálatokhoz, mivel a talajnedvesség-forgalom szimulálása mellett kiválóan alkalmazható a hőforgalom modellezésére is. További előnyt jelent, hogy a HYDRUS-1D nemzetközileg ismert, nyílt forráskódú program.

A HYDRUS-1D modell esősorban a víz-, anyag- és energiaforgalom szimulálására szolgál és az ezekre vonatkozó moduljai igen részletesek. A HYDRUS-1D modell a Richards 
egyenletet numerikusan oldja meg, ezért a talajban végbemenő vízáramlás leírásához szükséges a víztartóképesség- és a vízvezetőképesség-függvény megadása. Ennek megfelelően minden egyes modellezendő talajnál megmértük a vízvezető képességet, illetve a pF-görbe jellegzetes pontjait, melyekre a TALAJTANonc 1.0 program (Fodor és Rajkai, 2005) segítségével 3 paraméteres van Genuchten-függvényt (van Genuchten, 1980) illesztettünk.

A HYDRUS-1D a növényi fejlödést és növekedést nem számítja, inputként kell megadni a modellnek ha hosszabb valósidejü szimulációt végzünk, amikor növényzet is jelen van. A 4Mx modell által számított LAI eredményeket adtuk meg a HYDRUS-1D számára, mint bemenő adatot, hogy ne ez okozza az esetleges különbségeket a HYDRUS-1D és 4Mx modellek összehasonlításakor. A két modell közötti föbb különségeket a 2. táblázat szemlélteti.

\begin{tabular}{|c|c|c|}
\hline & HYDRUS-1D & $4 M x$ \\
\hline $\begin{array}{c}\text { Vízforgalom számítása } \\
\text { (szükséges adatok) }\end{array}$ & $\begin{array}{c}\text { Konduktív modell (Richards } \\
\text { egyenlet) } \\
\text { (víztartóképesség- és a } \\
\text { vízvezetöképesség-függvény) }\end{array}$ & $\begin{array}{c}\text { Kapacitív modell } \\
\text { (szabadföldi-, maximális-, } \\
\text { hervadás ponti vízkapacitás és } \\
\text { telítési vízvezető képesség) }\end{array}$ \\
\hline $\begin{array}{c}\text { Hőforgalom számítása } \\
\text { (szükséges adatok) }\end{array}$ & $\begin{array}{l}\text { mechanisztikus modell (Fourier } \\
\text { egyenlet) } \\
\left(\boldsymbol{\beta}_{\mathbf{t}} \text { : a hődiszperziós együttható; }\right. \\
\mathbf{b}_{\mathbf{1}}, \mathbf{b}_{2} \text { és } \mathbf{b}_{3} \text { : empirikus } \\
\text { paraméterek, melyek a talaj } \\
\text { homok, vályog és agyag } \\
\text { tartalmából becsülhetők) }\end{array}$ & $\begin{array}{c}\text { empirikus modell } \\
\text { (aktuális nedvességtartalom és } \\
\text { átlagos térfogattömegből } \\
\text { számított paraméterek) }\end{array}$ \\
\hline Függőleges felbontás & centiméteres & deciméteres \\
\hline Időbeli felbontás & dinamikus (másodperc - óra) & nap \\
\hline Növényi növekedés & bemenő adat & számított \\
\hline
\end{tabular}

2. táblázat: A HYDRUS-1D hidrológiai modell és a 4Mx növénytermesztési szimulációs modell összehasonlító táblázata.

A HYDRUS-1D modell segítségével szimuláltuk az őrbottyáni 2. mintaterületre vonatkozó talajhőmérséklet értékek alakulását 5, 10, 20, 40 és $60 \mathrm{~cm}$-es mélységekben, a talajnedvesség változás dinamikáját 0-10, 0-30, 0-80, 30-60 és 60-80 cm-es mélységekben, illetve a felszíni elfolyás mértékét zivatar folyamán. 


\subsubsection{A léptékfüggés megjelenése a meteorológiai adatsorok felhasználásakor}

A szimulált növény fejlődését meghatározza a napi hőösszeg mennyisége. Feltételezésünk szerint ennek értékét befolyásolhatja, hogy milyen rendszerességgel történik a hőmérsékleti adatok rögzítése. Ennek vizsgálatára a következő szimulációs kísérletet hajtottuk végre.

A 4Mx modell hőidő számító moduljával két módon is kiszámítottuk a 2010 első félévében Örbottyánban (2. mintaterület) mért hőmérséklet adatok alapján a vonatkozó időszak napi és kumulált hőösszegeit. A modell beállításai a 12. mellékletben olvashatók. Az első esetben az ötperces gyakorisággal mért adatokat használtuk fel. A másik esetben a napi minimum és maximum értékekből kiindulva szinuszos napi menetet feltételezve végeztük el a számítást (Sándor és Fodor, 2012b) (7. ábra).

A napi maximum és minimum hőmérsékletek alapján a modell kiszámolja a napi átlaghőmérsékletet ( $\mathrm{T}_{\text {átlag }}$ ), feltételezve, hogy a hőmérséklet változása szinuszos napi menetet követ. Ezek alapján kiszámolja a napi hőösszeget, amely tulajdonképpen az átlaghőmérséklet ( $\mathrm{T}_{\text {átlag }}$ ) és a bázishőmérséklet ( $\left.\mathrm{T}_{\text {bázis }}\right)$ közötti területtel egyezik meg (7. ábra).

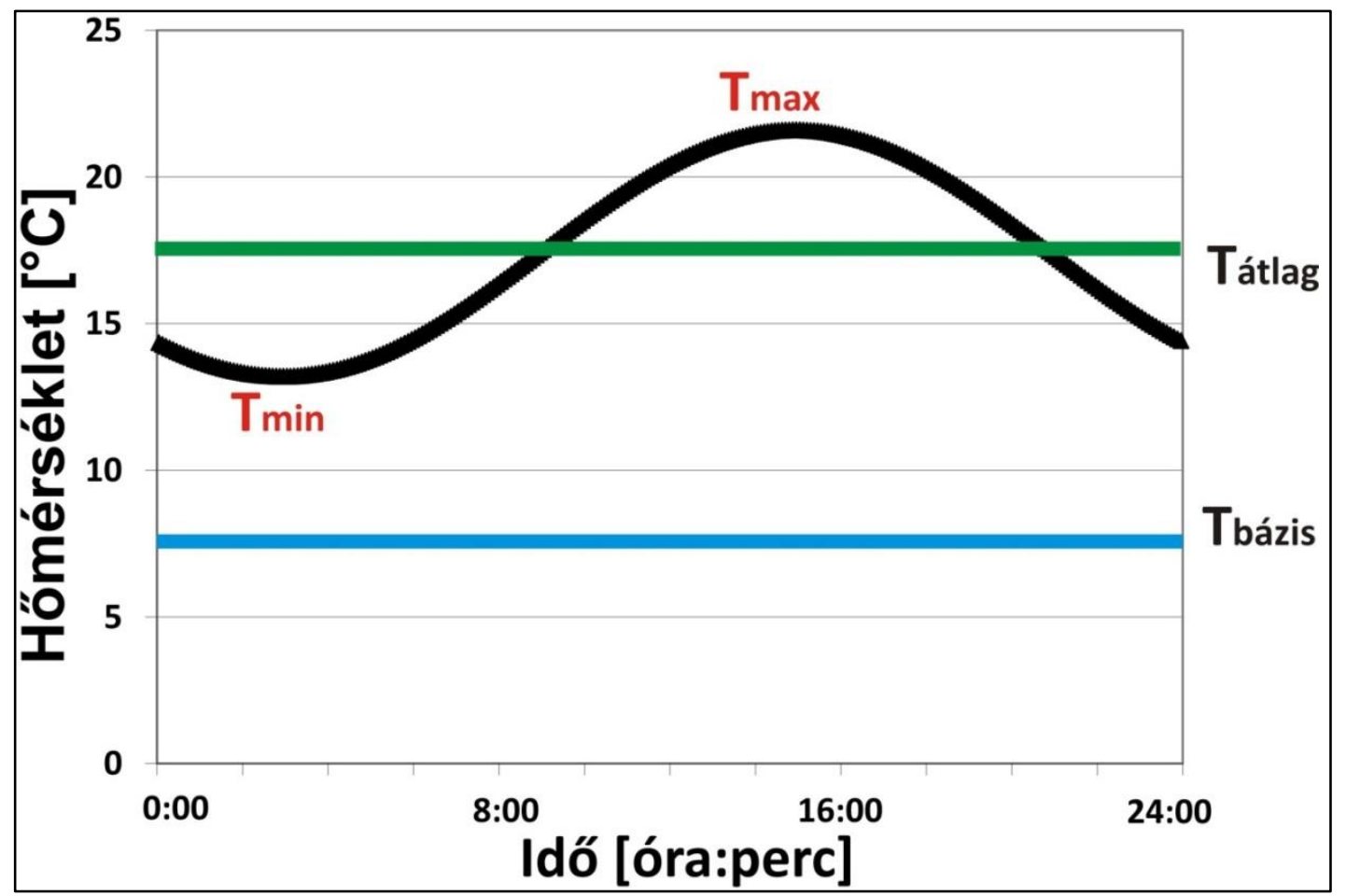

7. ábra: A hőmérséklet idealisztikus szinuszos napi menete. A fekete (feltételezett szinuszos napi menet) valamint a zöld (átlag hőmérséklet) görbék, illetve a kék (bázis hőmérséklet) görbe közé eső területek grafikusan szemléltetik a két hőösszeg-számítási módszert.

Amennyiben az ötperces gyakorisággal mért adatokat használjuk, akkor az 5 percenként számolt hőösszegek összegeként kapjuk meg a napi hőidő mennyiségét. Ez a hömérséklet napi menetének görbéje és a bázishőmérséklet ( $\left.T_{\text {bázis }}\right)$ közötti terület. 
Napi léptékű modellek esetén alapvetően azt feltételezzük, hogy a hőmérséklet napi alakulása szinuszos jellegü, és ezen szinusz görbe, valamint a hömérséklet tényleges alakulását megadó görbe, illetve a bázishömérséklet ( $\left.T_{\text {bázis }}\right)$ közötti terület megegyezik. Vannak azonban olyan esetek, amikor a hőmérséklet napi menete nem követi a feltételezett szinuszos lefutást. A különbségeket grafikus módszerrel értékeltük.

\subsubsection{Eltérő térléptékü modellekkel számított talajhőmérséklet értékek összehasonlítása}

A talajhőmérséklet modellezését megelőzően fontosnak tartottuk, hogy a bemutatásra kerüljenek a különböző mélységekben mért talajhőmérséklet értékek eltérése különböző és azonos növénytermesztési kezelésekben. Az örbottyáni 2. mintaterület 2. és 8. parcelláján, 5, 20 és 60 cm-es mélységekben megvizsgáltuk a növényborítottság talajhőmérsékletre gyakorolt hatását, 2011.07.14-én, mikor a maximális LAI értéket mértük. A parcellák kiválasztásánál két, igen eltérő levélfelületi értékkel rendelkező területet kerestünk, így esett a választásunk a műtrágyázott 8 . és a kontroll 2. parcellára. Az eltéréseket egyszerü statisztikai módszerekkel értékeltük.

Azonos növénytermesztési kezelések - mütrágyázott, nem öntözött parcellák — esetében a különböző mélységekben $(5,10,20,40$ és $60 \mathrm{~cm})$ mért talajhőmérséklet értékeket 2010.11.11. - 2011.10.04. között vizsgáltuk meg Örbottyánban. Az értékelést egyszerü statisztikai módszerekkel végeztük el 5 és $60 \mathrm{~cm}$-es mélységekben, mivel ezen adatsorok mutatták a legnagyobb különbséget.

A modell szimulációkat a HYDRUS-1D hidrológiai és 4Mx termésszimulációs modellek segítségével hajtottuk végre. A 4Mx modell talajhőmérséklet leíró egyenletének egy módosítását is elvégeztük, mely részletesen a 7.3.2. fejezetben olvasható. A megváltoztatott termésszimulációs modell neve: módosított 4Mx.

Vizsgálatainkat az őrbottyáni 2. mintaterület 1. parcelláján végeztük el, mivel a mütrágyázott, nem öntözött parcellán 2010.04.25-óta folyamatosan rögzítésre kerültek a talajhőmérséklet értékek $5,10,20,40$ és 60 cm-es mélységekben. Továbbá, parcellaválasztásunkat indokolja, hogy a modellezés során nem kell az öntözővíz módosító hatásával számolnunk. A vizsgálataink során az 5 mélységben mért talajhőmérséklet értékeket hasonlítottuk össze a HYDRUS-1D, 4Mx és a módosított 4Mx 5, 10, 20, 40 és $60 \mathrm{~cm}$ mélységekben modellezett eredményeivel. A hidrológiai és termésszimulációs modellek térléptéke nagyságrendnyivel eltér egymástól. A 4Mx modell deciméteres felbontást alkalmaz a talaj hőforgalmának számításakor, míg a HYDRUS-1D finomabb, centiméteres léptéket. 
Továbbá a két modell teljesen eltérő elven számítja a talajhőmérsékletet, mely modulok leírása az 5.1.1.1. és 5.1.1.2-es fejezetekben olvasható.

A HYDRUS-1D vízáramlást leíró moduljának kezdőfeltételét a TDR (ld.: 6.2.1.3.) szondával 10-80 cm-es mélységben, 3 ismétlésben mért talajnedvesség értékek átlagával adtuk meg. A kezdő talajhőmérséklet értéket $10{ }^{\circ} \mathrm{C}$-nak definiáltuk a teljes talajszelvény mentén, egészen a szimulált, $170 \mathrm{~cm}$-es mélységig. Az HYDRUS-1D nedvesség áramlási egyenletének megoldásához a következő peremfeltétel beállításokat adtuk meg: légköri peremfeltétel (atmospheric boundary conditions), felszíni elfolyás (surface runoff) és szabad vízelvezetés (free drainage), mint alsó peremfeltétel. A hőforgalom szimulálásához mind a két modell esetében az örbottyáni mintaterületen mért meteorológiai (ld.: 6.2.1.1.) adatokat használtuk fel, mint peremfeltétel. A HYDRUS-1D bemenő adatainak és paramétereinek megadása a 13. mellékletben olvasható.

A 4Mx modell beállításai során lényegesen kevesebb kezdő és peremfeltétel megadása volt szükséges, mivel a termésszimulációs modell leegyszerüsített módon számítja pl. a kapilláris vízemelést, illetve egyéb bemenő adatokból határozza meg a növényi adatokat fenológiai fázisonként, melyeket a HYDRUS-1D számára, mint input adat szükséges megadnunk. Ezért tudni szerettük volna, hogy milyen mértékü eltérés jelentkezik a HYDRUS-1D, 4Mx és módosított 4Mx szimulált talajhőmérséklet eredményei, és a mért értékek között.

A talajhőmérséklet modellezése során a LAI értékére kalibráltuk a 4Mx modellt (ld.: 7.3.2.), azért hogy a szimulált levélfelület értékek összhangban legyenek a mért értékekkel. A $4 \mathrm{Mx}$ modell beállítása a 14 . mellékletben olvasható. A 4Mx modell által számított napi felbontású levélfelület értékeket a HYDRUS-1D számításaihoz is felhasználtuk, azért, hogy a modell eredmények között ne a növényzet különbözősége okozza az eltérést. A mért és számított talajhőmérséklet értékek összehasonlítása T-próbával és grafikus módszerekkel történt.

\subsubsection{Mért és szimulált talajnedvesség értékek összehasonlítása, növénytermesztési kísérlet kezelésében}

Az örbottyáni 2. mintaterület mért talajnedvesség adatait hasonlítottuk össze a HYDRUS-1D hidrológia modell cm-es és dm-es felbontású szimulált eredményeivel. A modell szimulációkat 2010.03.31. és 2013.04.18. közötti időszakra végeztük el a 2. parcellán. A parcella kiválasztásánál fontosnak tartottuk, hogy kezelés (öntözés és/vagy mütrágya) hatás ne befolyásolja a modellezett eredményt, így pontosabb képet kaphassuk arra vonatkozóan, hogy a modell mennyire képes követni a talajnedvesség változását. Továbbá a 2. parcella esetében 
többször mértünk 0,0 \%-os talajnedvesség tartalmat a 0-10 cm-es zónában és tudni szerettük volna, vajon a modellezett eredmények esetében jelentkezik-e ilyen mértékủ nedvesség hiány. A talaj modul leírásánál a mért, parcellákra vonatkozó értékeket adtuk meg, a mélység függvényében.

Mind a deciméteres, mind pedig a centiméteres felbontású szimulációnál $171 \mathrm{~cm}$ mélységű talajszelvény írtunk le. A talaj modul leírásánál a mért, parcellákra vonatkozó értékeket adtuk meg, a mélység függvényében. Az őrbottyáni szelvényleírásnak megfelelően 4 talajszintet definiáltunk, 0-30, 30-60, 60-90 és 90-171 cm. Az örbottyáni meteorológiai állomáson rögzített időjárási adatokat használtuk fel a szimulációkhoz. Az HYDRUS-1D nedvesség áramlási egyenletének megoldásához a következő peremfeltételeket adtuk meg: légköri peremfeltétel (atmospheric boundary conditions), felszíni elfolyás (surface runoff) és szabad vízelvezetés (free drainage), mint alsó peremfeltétel. A részletes modellbeállítás a 12. mellékletben olvasható.

A vizsgált időszakban 47 alkalommal történt talajnedvesség mérés $10 \mathrm{~cm}$-es felbontásban, a felszíntől $80 \mathrm{~cm}$-es mélységig, mely időpontokra történt a különböző felbontású szimulációs eredmények kiíratása is. A mért és szimulált talajnedvesség értékek összehasonlítása varianciaanalízissel, T-próbával és grafikus módszerekkel történt.

\subsubsection{Beszivárgás és talajpárolgás modellezésének térbeli léptékfüggése}

Az alábbiakban részletezésre kerülő szimulációs modellkísérlettel arra kerestük a választ, hogy milyen mértékü különbség adódik a beszivárgás és a talajpárolgás számított mennyiségében annak függvényében, hogy a modell $\mathrm{cm}$-es vagy dm-es talajszelvény felbontást alkalmaz. A kérés megválaszolására a 4Mx modellbeállítása során a legfelső talajréteget $10,9,8,7,6,5,4,3,2$, illetve $1 \mathrm{~cm}$ vastagnak definiáltuk. Mind a két esetben (1 $\mathrm{cm}$ és $10 \mathrm{~cm}$ ) az őrbottyáni mintaterület talajjellemző értékeit adtuk meg a modellszámításokhoz. A definiált felső talajréteg alatt elhelyezkedő szintek talajtulajdonságainak megadása a szelvény leírásának megfelelően történtek (ld.: 13. melléklet). A szimulációt ugar beállításával végeztük el. Az időjárási adatok megadásnál az őrbottyáni 2. mintaterület meteorológiai állomásán 2012. 06.01. - 2012.07.06. között mért, napi felbontású hőmérsékleti értékeket használtuk. Azért ezt az időszakot választottuk, mert 2012.06.01-jén $42 \mathrm{~mm}$ csapadékösszeget rögzítettünk, zivatar formájában. A modell szimuláció során vizsgáltuk a zivatar beszivárgás, illetve a felszíni elfolyás valamint a talajpárolgás mértékét az azt követő csapadékmentes 1 hónap alatt, a beállított talajréteg vastagságának függvényében. 


\subsubsection{A térbeli heterogenitás következtében előálló modellezési problémák különböző szimulációs technikák esetén}

A HYDRUS-1D modell segítségével szimuláltuk a talajnedvesség változását az őrbottyáni karbonátos homoktalaj 1 méter mély szelvényében. Előzetesen a terület 5 pontjában Guelph permeaméter segítségével megmértünk a vízvezető képesség értékeket, melyeket felhasználtunk a szimulációk során (ld. 14. melléklet). A következő - természetben is előforduló - zivatar intenzitásokat szimuláltuk: 0,0125, 0,025, 0,04 és $0,05 \mathrm{~mm} / \mathrm{sec}$. A modell szimulációit kétféle módon végeztük el. Első esetben minden egyes mért $\mathrm{K}_{\mathrm{S}}$ értékkel lefuttattuk a modellt, majd a kapott beszivárgási eredményeket átlagoltuk (Caltulate first, Interpolate later; $C I$ ), míg a másik eset során az 5 mérés átlagolt hidraulikus vezetőképesség értékével végeztük el a modell futtatását (Interpolate first, Calculate later; IC). A szimulációs módszerek bővebb leírást lásd az 5.2.11. fejezetben.

Amikor a modell szimulációt megelőzően átlagoljuk a vízvezető képesség értékeket, a $\mathrm{K}_{\mathrm{S}}$ értékek területi különbségeit homogenizáljuk, melynek következtében már nem beszélhetünk léptékfüggésröl. Azonban, ha külön-külön végezzük el a $K_{S}$ értékekre a modell szimulációkat, akkor a vízvezető képesség térbeli változatosságát is modellezzük. Az utóbbi esetben a modell szimulációk átlaga már rendelkezik léptékfügéssel. A két módszerrel kapott eredményeket grafikus összehasonlítással értékeltük. 


\section{EREDMÉNYEK éS KÖVETKEZTETÉSEK}

\subsection{A VIZSGÁLT TALAJOK HIDROLÓGIAI PARAMÉTEREI}

A víztartóképesség-függvényeket mind az 5 kísérleti terület felső, 5-10 cm-es szintjében 5-5 ismétlésben, bolygatatlan talajmintákból határoztuk meg. Az őrbottyáni 2. mintaterületen a talajprofil 3 szintjére $(5-10 \mathrm{~cm}, 35-40 \mathrm{~cm}$ és $65-70 \mathrm{~cm})$ két ismétlésben mértük meg a pF értékeket parcellánként (ld.: 4. melléklet).

A csólyospálosi és őrbottyáni homoktalajú kísérleti területek pF-görbéi a 8. ábrán, a nagyhörcsöki, martonvásári és szurdokpüspöki vizsgált talajoké a 9. ábrán látható.

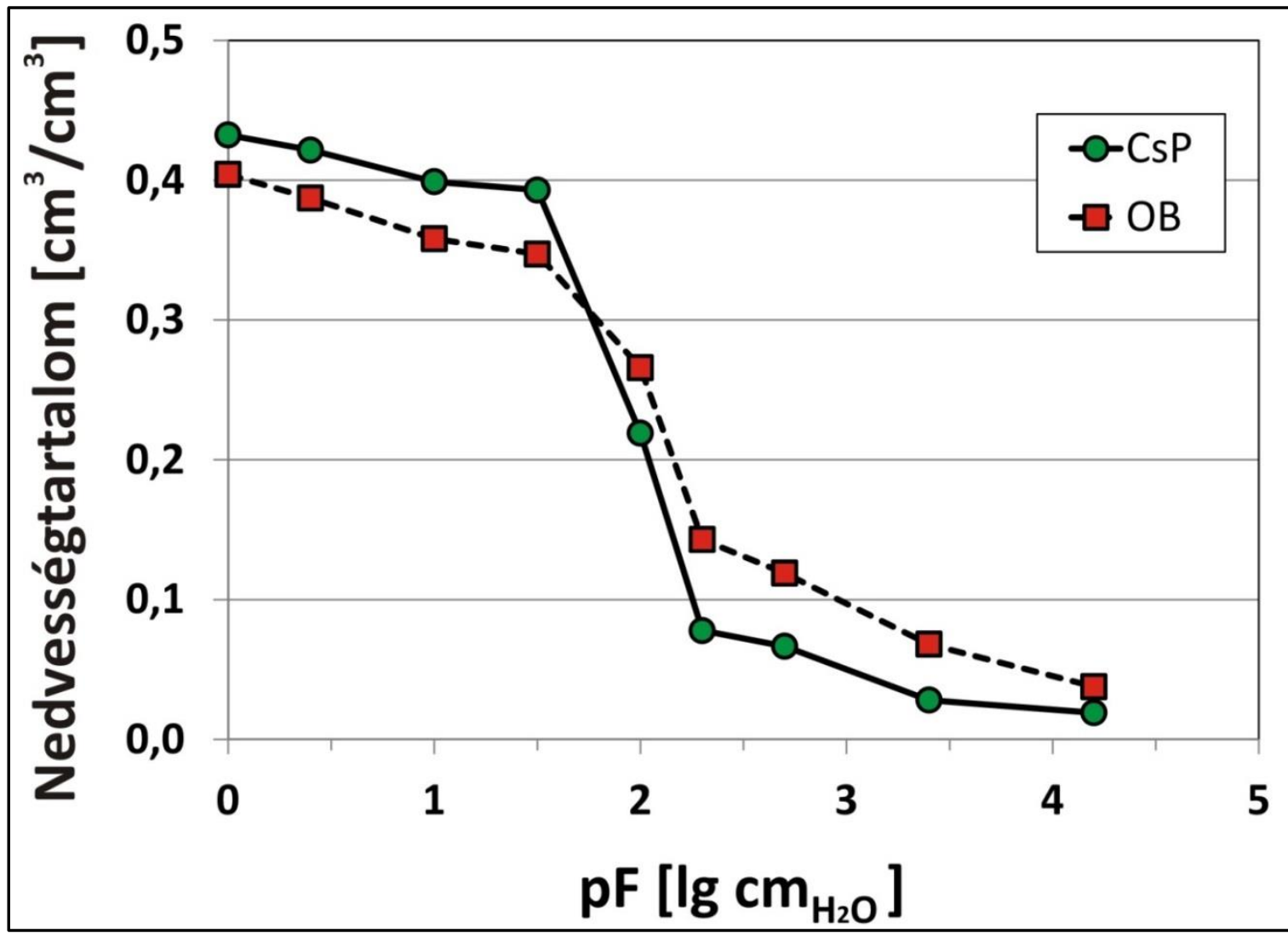

8. ábra: Az őrbottyáni (OB, piros négyzet) és csólyospálosi (CsP, zöld kör) talajok pF-görbéi 5-10 cm-es mélységekben. (Örbottyán, 2009; Csólyospálos, 2012)

A pF 0 értékhez tartozó talajnedvesség a telített állapotot jellemzi $\left(\Theta_{\max }\right)$ (Stefanovits, 1992). A 8. és 9. ábrát összehasonlítva jól látható, hogy csólyospálosi és örbottyáni homoktalajok maximális vízkapacitás értékei, illetve a szurdokpüspöki, nagyhörcsöki és martonvásári területekre jellemzö $\Theta_{\max }$ értékek hasonlóak. Az általunk vizsgált homoktalajok víztartóképességének lényeges csökkenése $\mathrm{pF}=1,5$ és a szabadföldi vízkapacitást $\left(\Theta_{\mathrm{fc}}\right)$ $\mathrm{pF}=2,3$ - értékei között figyelhetök meg. A martonvásári homokos-vályog (9. ábra) esetében a víztartóképesség csökkenése jelentősen nagyobb szívóerő tartományban következik be, míg Nagyhörcsök és Szurdokpüspöki esetében egyenletes csökkenés figyelhető meg. A vizsgált 
talajok közül a szudokpüspöki agyagtalaj hervadásponti vízkapacitás $\left(\Theta_{\mathrm{wp}}\right)$ értéke $-\mathrm{pF}=4,2$ — a legmagasabb, 25,5 \%, mely fele az 51,2 \%-os maximális vízkapacitás értékének.

A növények számára a maximálisan elérhető nedvesség a szabadföldi $\left(\Theta_{\mathrm{fc}}\right)$ és a hervadásponti vízkapacitás $\left(\Theta_{\mathrm{wp}}\right)$ értékek különbsége, mely alapján a martonvásári homokos vályog és a nagyhörcsöki vályog talajok szolgáltatják a legtöbb vizet a gyökereknek.

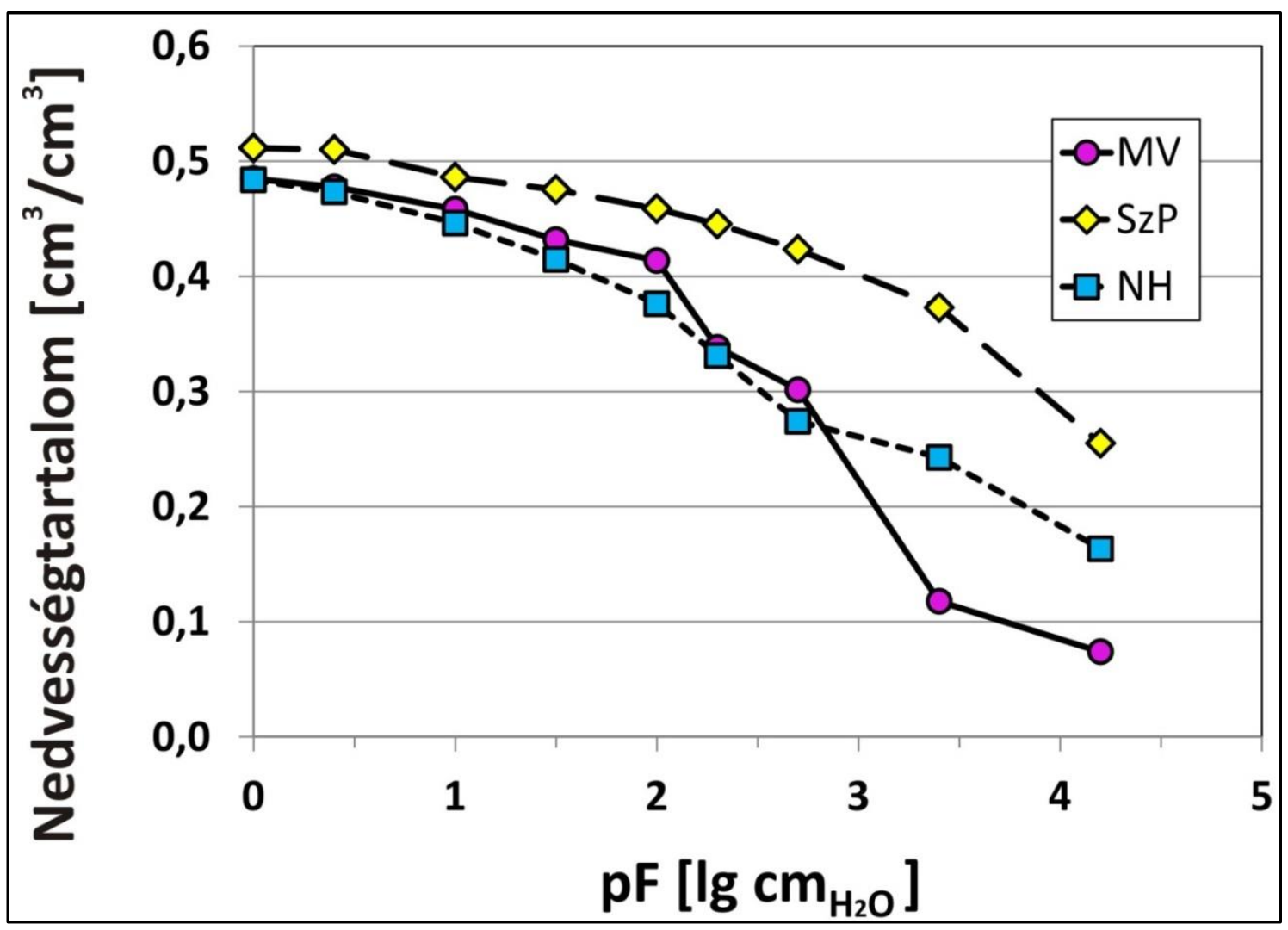

9. ábra: A martonvásári (MV, lila kör), nagyhörcsöki (NH, kék négyzet) és szurdokpüspöki (SzP, sárga rombusz) mintaterületek pF-görbéi 5-10 cm-es mélységekben. (Martonvásár, 2011; Szurdokpüspöki, 2012;

Nagyhörcsök, 2009)

\begin{tabular}{|c|c|c|}
\hline Hely & $\boldsymbol{\alpha}$ & $\mathbf{n}$ \\
\hline Csólyospálos & 0,0153 & 2,191 \\
\hline Örbottyán & 0,0162 & 1,682 \\
\hline Nagyhörcsök & 0,0023 & 1,344 \\
\hline Martonvásár & 0,00688 & 1,414 \\
\hline Szurdokpüspöki & 0,000189 & 1,805 \\
\hline
\end{tabular}

3. táblázat: A mintaterületek 5-10 cm mélységű talajrétegeinek van Genuchten paraméterei.

Az 5-10 cm mélységben mért pF-görbe értékek mintaterületenkénti átlagára illesztett 3 paraméteres van Genuchten-függvény paraméterek értékeit (3. táblázat) felhasználtuk a feltalajon mért MDI mérések kiértékeléséhez, melyekkel a $\mathrm{K}_{\mathrm{S}}$ értékét határoztuk meg (ld.: 7.2.1., 7.2.2., 7.3.3. és 7.3.4. fejezetek). 
7.2. HIDRAULIKUS TUALJDONSÁGOK IDÖ-, és TÉRBELI LÉPTÉKFÜGGÖ VIZSGÁLATA

\subsubsection{A telítési vízvezető képesség időbeli változása}

Csólyospáloson, a kísérlet 3 hónapja alatt összesen $57 \mathrm{~mm}$ csapadék hullott a mintaterületre, melyből 37 mm-t a vizsgálati időszak első 6 napjában mértünk. A kísérlet ideje alatt lehulló csapadék naponkénti megoszlása a 18. mellékletben olvasható. A $\mathrm{K}_{\mathrm{S}}$ talajmüvelést követő változása a kumulált csapadék függvényében a 10. ábrán látható.

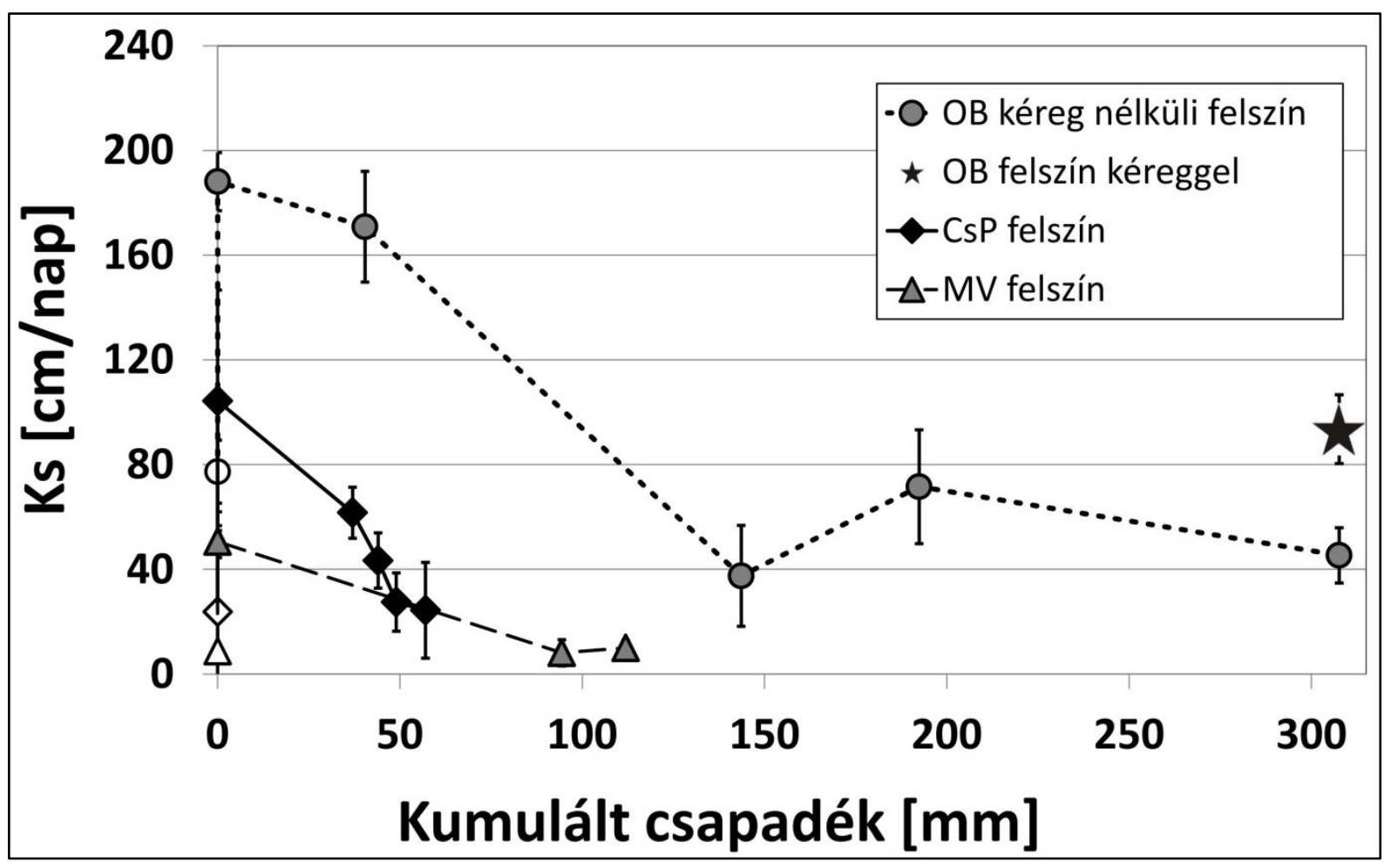

10. ábra: Hidraulikus vezetőképesség $\left(\mathrm{K}_{\mathrm{S}}\right)$ a kumulált csapadék függvényében Örbottyán (OB), Csólyospálos (CSP) és Martonvásár (MV) mintaterületeken. Hibasávok: az átlagtól való maximális eltérés. Szürke kör: $\mathrm{K}_{\mathrm{S}}$ mérés Örbottyánban, fehér kör: a $K_{S}$ müvelés előtti kiindulási állapota Örbottyánban, fekete csillag: kéreg eltávolításával mért $\mathrm{K}_{\mathrm{S}}$ érték Örbottyánban. Fekete rombusz: $\mathrm{K}_{\mathrm{S}}$ mérés Csólyospáloson, fehér rombusz: a $\mathrm{K}_{\mathrm{S}}$ müvelés előtti kiindulási állapota Csólyospáloson. Szürke háromszög: $K_{S}$ mérés Martonvásárban, fehér háromszög: a $\mathrm{K}_{\mathrm{S}}$ müvelés előtti kiindulási állapota Martonvásárban.

Talajmüvelést követő időszakban, Mini Disk Infiltorméterrel mért hidraulikus vezetőképesség és a térfogattömeg időbeli változását szemlélteti a 11. ábra, Csólyospálos (11a. ábra) és Örbottyán (11b. ábra) mintaterületén.

A csólyospálosi mintaterületen a visszatömörödés üteme gyors és egyenletes (11a. ábra) volt, a mért térfogattömeg értékek változása alapján. A kiegyensúlyozott visszatömörödési ütemmel párhuzamosan egyenletesen csökkenő tendenciát mutattak a vízvezető képesség értékek. Az eredeti állapotról $\left(\mathrm{K}_{S}=23,8 \mathrm{~cm} / \mathrm{nap}\right)$ a talajművelés megnégyszerezte a hidraulikus vezetőképesség értékét $\left(K_{S}=104,3 \mathrm{~cm} / \mathrm{nap}\right)$, mely 6 nap alatt 
közel a felére csökkent vissza $\left(K_{S}=61,6 \mathrm{~cm} / \mathrm{nap}\right)$. A továbbiakban mérséklödött ugyan a visszaülepedés mértéke, de közel 3 hónap elegendő volt ahhoz, hogy teljesen visszaálljanak a vízvezető képesség és térfogattömeg értékek a művelés előtti, kiindulási állapotra.

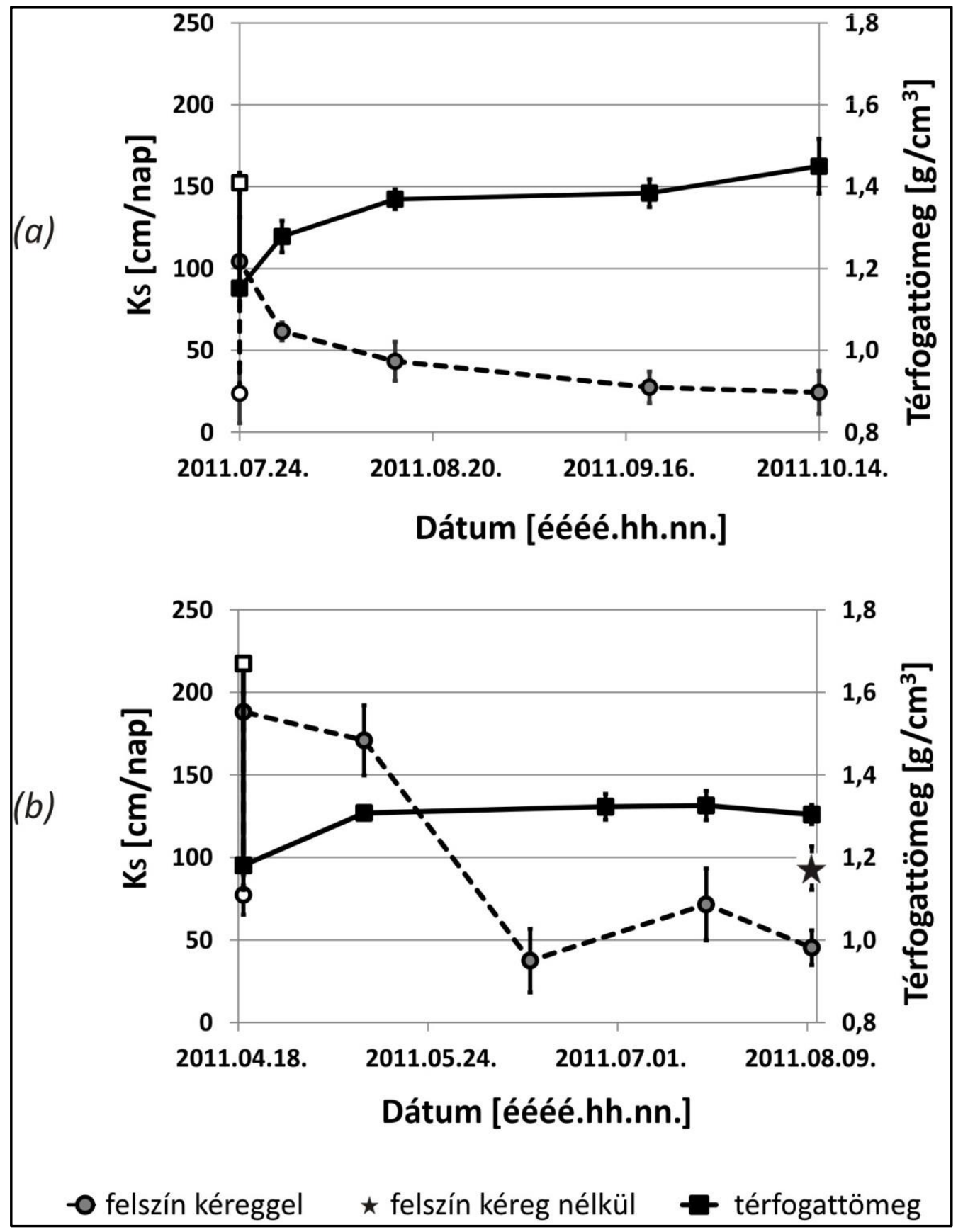

11. ábra: A telítési vízvezető képesség $\left(\mathrm{K}_{\mathrm{S}}\right)$ és a térfogattömeg változása az idő függvényében, Csólyospálos (a) és Örbottyán (b) mintaterületeken. Hibasávok: az átlagtól való maximális eltérés. Fekete négyzet: térfogattömeg mintavétel, fehér négyzet: térfogattömeg művelés elötti kiindulási állapota, szürke kör: mért $K_{S}$, fehér kör: $K_{S}$ müvelés előtti kiindulási állapota.

Az őrbottyáni mintaterületen (11b. ábra) a müvelést követően lassú ütemben megindult a vízvezető képesség csökkenése, mellyel párhuzamosan a térfogattömeg értékek növekedése figyelhető meg. Azonban, 2011.06.14-dikei mérésnél azt tapasztaltuk, hogy a 
hidraulikus vezetöképesség értéke a kezdeti érték $\left(K_{S}=77,3 \mathrm{~cm} /\right.$ nap) majdnem felére $\left(K_{S}=37,5\right.$ $\mathrm{cm} / \mathrm{nap}$ ) esett vissza, miközben a térfogattömeg mérés eredményei ellentmondtak egy ilyen nagymértékü visszatömörödésnek. A térfogattömeg értékek alapján a talaj még lazának tủnt, nagyobb vízvezető képesség értékeket vártunk a mérteknél.

A jelentős különbségek hátterében az állhat, hogy a 2011.05.12-dikei és 2011.06.14dikei mérések között $123 \mathrm{~mm}$ csapadék esett, mely során háromszor fordult elő $20 \mathrm{~mm}-\mathrm{t}$ meghaladó intenzív csapadékesemény (ld.: 19. melléklet). Ezek hatására a talaj felszínén néhány mm-es kéreg keletkezett, amely tapintással is érzékelhető volt. A kéreg alapjául az őrbottyáni homoktalajban található magasabb $\mathrm{CaCO}_{3}$ tartalom szolgálhatott, de hozzájárulhatott a csólyospálosi talajnál magasabb agyag és vályog tartalom is.

A kéreggel mért hidraulikus vezetőképesség átlagérték $\left(K_{S}=45,3 \mathrm{~cm} /\right.$ nap) és a kéreg eltávolítását követően mért átlagérték $\left(\mathrm{K}_{\mathrm{S}}=93,5 \mathrm{~cm} / \mathrm{nap}\right)$ (11b. ábra, csillaggal jelölt érték) lényegesen eltértek egymástól. A térfogattömeg változásában a 2011.06.14-edikei mérést követően alig következett be növekedés, miközben 184,6 mm csapadék hullott.

Örbottyánban, a vizsgálat közel 4 hónapja alatt a kéreg nélkül mért hidraulikus vezetöképesség érték $\left(K_{S}=93,5 \mathrm{~cm} / \mathrm{nap}\right)$ közel visszaállt az eredeti állapotra $\left(\mathrm{K}_{\mathrm{S}}=77,3\right.$ $\mathrm{cm} / \mathrm{nap})$, míg a kéreggel mért $\mathrm{K}_{\mathrm{S}}\left(\mathrm{K}_{\mathrm{S}}=45,3 \mathrm{~cm} / \mathrm{nap}\right)$ jelentősen alacsonyabb, mint a kezdeti telítési vízvezető képesség érték. A térfogattömegek esetében nem állt helyre az eredeti állapot. A bolygatást megelőzően $1,67 \mathrm{~g} / \mathrm{cm}^{3}$ volt a talaj térfogattömege és közel 4 hónap elteltével is még csak $1,30 \mathrm{~g} / \mathrm{cm}^{3}$-t mértünk.

A martonvásári homokos-vályog talajmüvelést követő visszatömörödése (12. ábra) egyenletesen és gyorsan végbement. A hidraulikus vezetőképességet tekintve szinte 2 hónap alatt visszaállt a kezdeti $8,7 \mathrm{~cm} /$ nap -os érték. A térfogattömeg értékek azonban nem álltak vissza a talajbolygatást megelőző állapotra a kísérlet több mint 3 hónapja alatt. A talaj felső 5 $\mathrm{cm}$-es rétege $1,11 \mathrm{~g} / \mathrm{cm}^{3}$-re tömörödött vissza, szemben az eredeti $1,28 \mathrm{~g} / \mathrm{cm}^{3}$-es értékkel. Martonvásárban, a kísérlet 3 és fél hónapja alatt összesen 111,9 mm csapadék hullott a mintaterületre, melyből egy csapadékesemény 20 mm-t meghaladó volt (ld.: 20. melléklet).

A martonvásári hidraulikus vezetőképesség gyorsabb helyreállását magyarázhatja, hogy a vályog talajban lévő finomabb frakciójú szemcsék (pl.: agyag) eltömíthetik a talaj nagyobb pórusait, melyhez a talaj karbonát tartalma is hozzájárulhat. Ez a kérgesedési jelenség hasonló, mint az Őrbottyánban megfigyelt, de makroszkopikus megfigyeléseink alapján a martonvásári kéreg kevésbé volt vastag és tömör. 


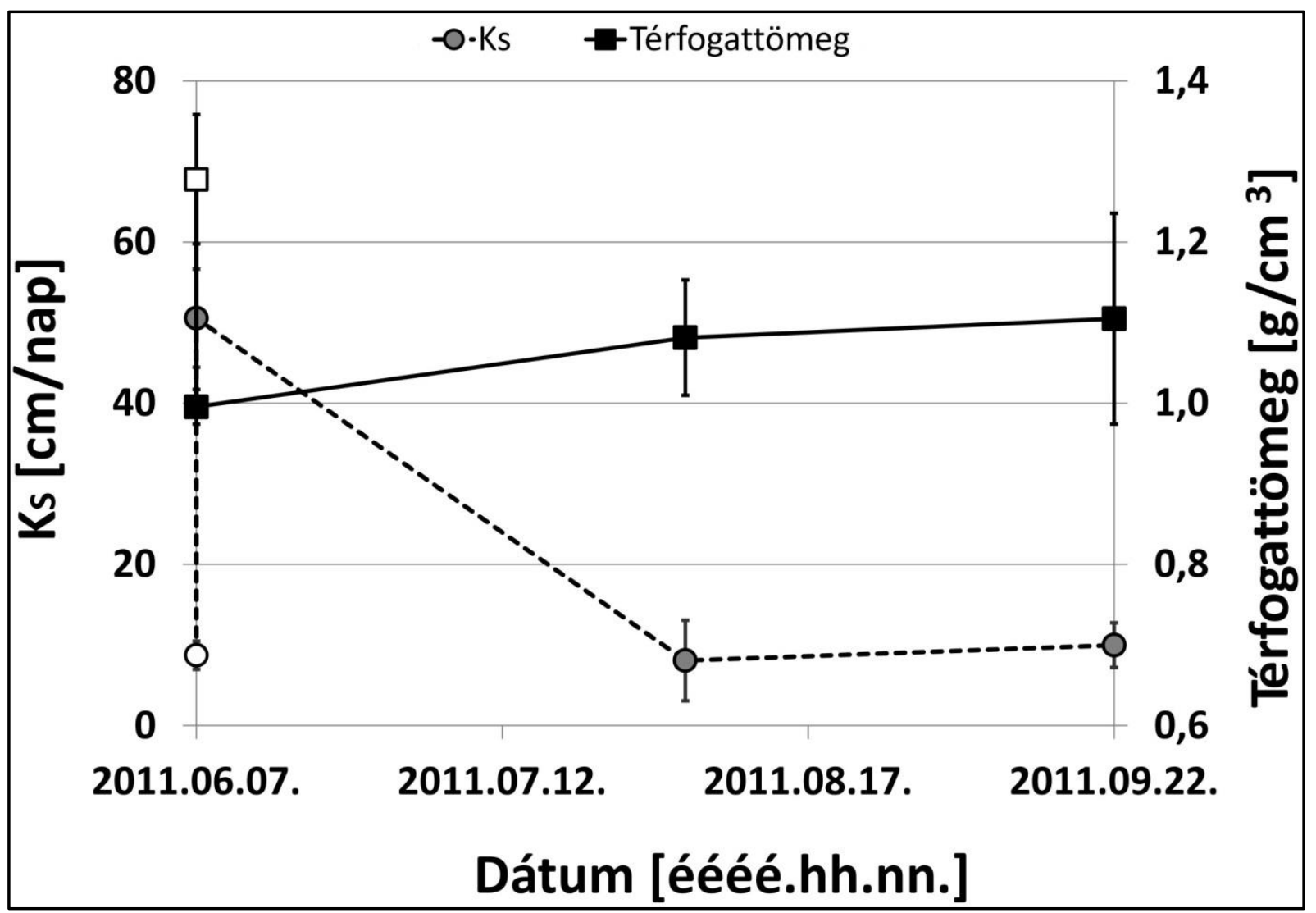

12. ábra: A telítési vízvezető képesség $\left(\mathrm{K}_{\mathrm{S}}\right)$ és a térfogattömeg változása az idő függvényében Martonvásár mintaterületén. Hibasávok: az átlagtól való maximális eltérés. Fekete négyzet: térfogattömeg mintavétel, fehér négyzet: térfogattömeg müvelés elötti kiindulási állapota, szürke kör: mért $K_{S}$, fehér kör: $K_{S}$ művelés előtti kiindulási állapota.

Egy terület müvelés előtti állapotára történő visszaülepedésének mértéke függ a területre hulló csapadék mennyiségétől (Messing és Jarvis, 1993; Lampurlanés és CanteroMartínez, 2003;). Mind a három kísérleti terület esetében a csapadék volt a fö tömörítő tényező bolygatást követően. A telítési vízvezető képesség és térfogattömeg értékek eredeti állapotra történő visszaállásra kb. 2 hónap elegendő, lásd Csólyospálos esetében. Azonban, az Örbottyánban lehullott jelentős mennyiségü csapadék nem fejtette ki tömörítő hatását a talajszerkezetre, mivel a heves esőzések hatására keletkezett karbonátos kéreg meggátolta azt. Ugyanakkor a $K_{S}$ jóval a müvelést megelőző kiindulási érték alá csökkent, amely arra utal, hogy a kéregben a durvább szemcsék közötti pórusokat a finomabb (pl.: agyag, karbonát) részecskék eltömíthették (clogging). Ezt a jelenséget figyeltük meg a martonvásári terület esetében is. Az összecementált kéreg hatására a hidraulikus vezetőképesség értékek gyorsan visszacsökkentek a müvelés elött mért $\mathrm{K}_{\mathrm{S}}$ értékekre, miközben a térfogattömegek mért eredményei nem támasztották alá ezt a gyors visszatömörödési ütemet.

A fenti vizsgálatok következtében, mind a homok, mind pedig a vályog talajok bolygatást követő modellezése során célszerü figyelembe venni a térfogattömeg és a 
vízvezető képesség változását a csapadék függvényében. Eddig olyan modelleket fejlesztettek, ahol a hidrológiai bemenő adatok (pl.: $\mathrm{K}_{\mathrm{S}}$ ) rögzített értéküek, ennél fogva ezek a modellek nem képesek kezelni a vonatkozó folyamatok időbeni léptékfüggését. Azonban a $\mathrm{K}_{S}$ a kumulatív csapadék függvényében exponenciális jellegü függvénykapcsolatot mutat. Kísérletet lehetne tenni arra, hogy egy egyszerü empirikus (al)modellel leírjuk ezt a jelenséget és időben változó paramétereket definiáljunk a modellben. Így a fentiek alapján javaslom, hogy lehessen definiálni egy időbeli változékonyságot a bemenő adatok esetében, azért, hogy a modellek jobban közelítsék a valóságot. Azonban, felhívnám a kéregképződés problémájára a figyelmet, mivel ez a jelenség módosítja mind a mért $K_{S}$, mind pedig a térfogattömeg értékek müvelést követően, az eredeti állapotra történő visszatömörödési ütemét. A kéregképződést az intenzív csapadékesemények tömörítő hatása idézheti elö, melyek gyakorisága - a klímaváltozás következtében —, az elörejelzések szerint növekedni fog (Knapp et al., 2008; Hartmann et al. 2012). Így javaslom, a 20 mm-t meghaladó csapadékesemények esetén a $K_{S}$ értékek müvelést követő változásának követését, ezáltal az időbeli változékonyság nagyobb mértékü figyelembevételét.

\subsubsection{A hidraulikus tulajdonságok térbeli variabilitása}

\subsubsection{A talajok viztaszitás értékének térbeli változatossága}

Az $1 \mathrm{~m}^{2}$-es terület 100 cellájának WDPT módszerrel mért víztaszítás értékeit Dekker és Ritsema (1996) módszerével meghatározott talajnedvesíthetőség kategóriákba soroltuk, ld.: 13. ábra. Csólyospálos és Örbottyán területén mért víztaszítás értékek a 21. mellékletben olvashatók.

A csólyospálosi homoktalaj víztaszító (13a. ábra), helyenként erősen víztaszító. A víztaszításnak több lehetséges oka van: az élö és/vagy bomló növényi-, vagy mikroorganikus maradványok lebomlásából származó szerves vegyületek (Doerr et al., 2000; Hallett, 2007; Lichner et al., 2012), továbbá hidrofób/amfifil komponensek — pl.: növényi levél, szár és gyökerek bomlástermékei, maradványai, gyantái és viaszai — is elöidézhetik (DeBano, 1969; Bisdom et al., 1993; Dekker et al., 2001; Moradi et al., 2012), mely utóbbiak hidrofób bevonatot képezhetnek a talajrészecskék körül (Ellies et al., 2005).

Az őrbottyáni homoktalaj nem tekinthető víztaszítónak. 100 mérésből csupán 1 pontot mértünk víztaszítónak, 1 pontot pedig erősen víztaszítónak (13b. ábra), melynek több oka is lehet. Az őrbottyáni mintaterülettől kb. 20 méterre található egy idősebb (30 éves) telepített fenyves (Pinus Sylvestris), mely fáiról is származhat talajnedvesíthetőséget befolyásoló 
gyanta (Lichner et al., 2012), illetve okozhatják egyéb szerves maradványok is (pl.: viasz, hangyasav, növényi maradványok).

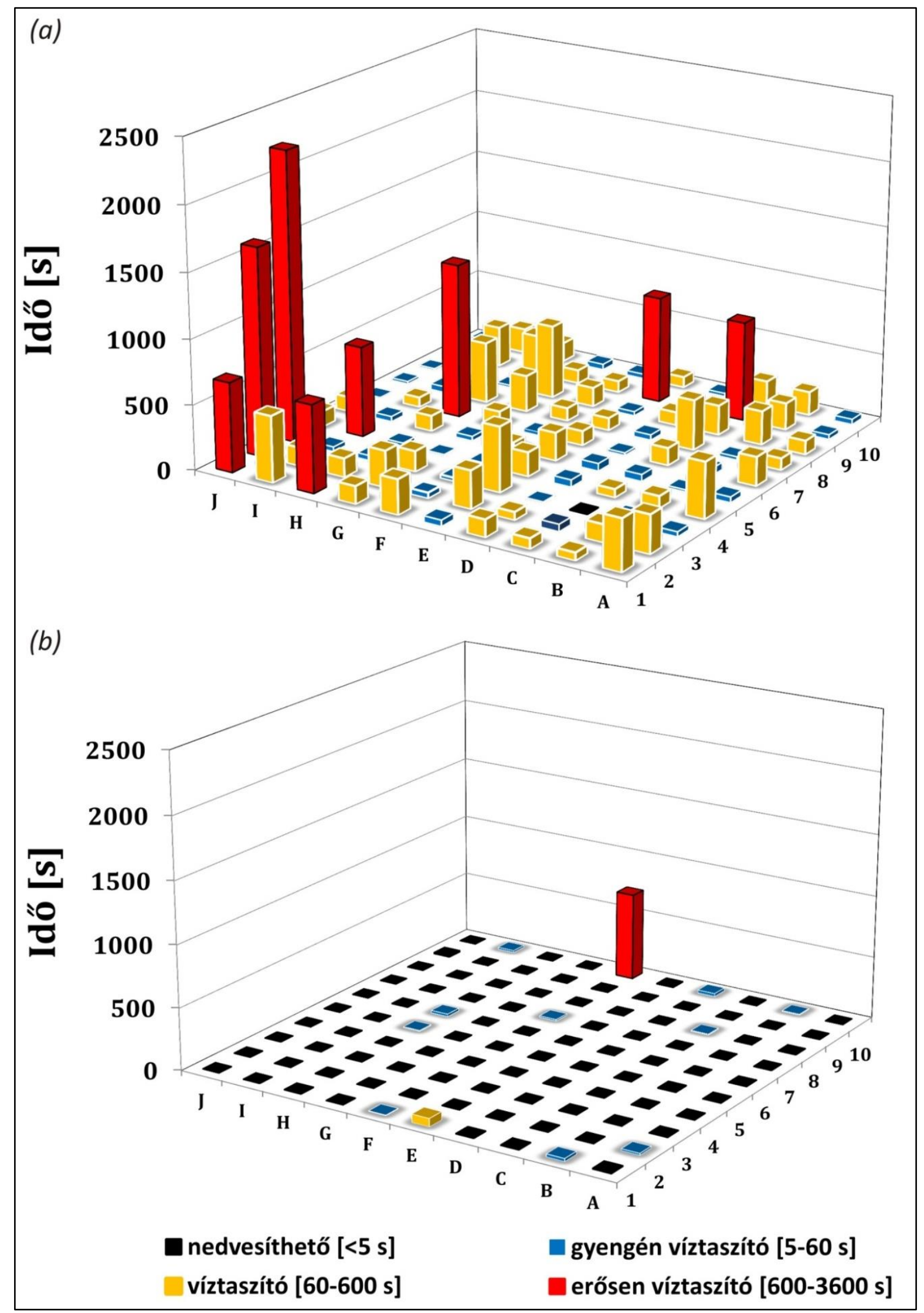

13. ábra: A talajok víztaszításának $1 \mathrm{~m}^{2}$-en belüli variabilitása Csólyospálos (a) és Örbottyán (b) mintaterületén, 2012. május 3-án (a) és 2012. május 31-én (b). 
Örbottyán esetében a talaj lúgoldható szén mennyisége $0,36 \%$, fulvosav mennyisége pedig $0,35 \%$. Tehát az őrbottyáni talajban található huminsav mennyisége $0,01 \%$. Az őrbottyáni talaj HA/FA aránya tehát: 0,04. A talaj lúggal kivonható humusz-frakcióinak mennyisége 0,64\%, mely kétharmada a klasszikus Tyurin módszerrel mért, 0,91\% szervesanyag-tartalomnak.

A csólyospálosi talaj esetében $0,30 \%$ fulvosav tartalmat mértünk. A talaj huminsav tartalma a kimutathatósági határ alatt maradt. Így a lúgoldható humusz mennyisége 0,51\%, mely szignifikánsan kevesebb, mint a klasszikus Tyurin módszerrel mért átlagos 1,62 \%.

Az örbottyáni és csólyospálosi talajok fulvosav mennyisége hasonló, azonban az őrbottyáni talaj huminsav tartalma mérhető mennyiségü volt. Az eddigi vizsgálatok a huminsav és fulvosav arányát (HA/FA) jó indikátornak találták a talaj víztaszításával kapcsolatban (Singer és Ugolini, 1976), miszerint a huminsavak - lévén nagyobb molekulatömegűek és ebből kifolyólag jóval hidrofóbbak, mint a fulvosavak — okozhatják az adott talaj víztaszítását. Vizsgálataink nem erősítik meg ezt a hipotézist, hiszen annak ellenére, hogy a csólyospálosi talaj alig tartalmaz huminsav-frakciót, víztaszítása igen jelentős, különösen a mérhető huminsavat tartalmazó őrbottyáni talajjal összevetve.

A fenti mérések értelmében a csólyospálosi talaj víztaszító, helyenként erősen víztaszító.

Ezért a feltételezésünk az, hogy a csólyospálosi talaj víztaszítását nem a huminsavak dominanciája okozza, hanem a talajban előforduló egyéb hidrofób karakterű anyagok. Ezek jelenlétére utal a talaj összes szervesanyag-tartalma és a lúggal kivont szervesanyag-tartalom közötti nagy különbség a csólyospálosi talajnál, mely jóval nagyobb, mint az őrbottyáni homok esetében. Ezek az anyagok a növényekből vagy akár az állati szervezetekből származó vegyületek, sokszor makromolekulák. Ezek a nem, vagy csak részben, humifikálódott, azaz kémiailag nem átalakult (oxidáció, degradáció) biopolimerek sokkal hidrofóbabbak lehetnek, mint a már humifikálódott szervesanyag, amely szerkezetében a kémiai átalakulások különböző poláris részeket, hidrofil funkciós csoportokat hozhatnak létre (Hayes és Clapp, 2001). Ez okozhatja az őrbottyáni és csólyospálosi talajok vízáteresztő képességében tapasztalt jelentős különbségeket (ld.: 7.2.2.2.). Azonban a víztaszításhoz hozzájárulhat még a csólyospálosi régi barackos enyv és viasz kiválasztása, továbbá a homoktalaj durvább szemcséit fulvosav is bevonhatja (Dekker et al., 2005). 


\subsubsection{A telítési vizvezetö képesség térbeli változatossága}

A csólyospálosi telítési vízvezető képesség adatok kiértékelése során különös gondossággal kellett eljárnunk, mivel az előzetes vizsgálatok szerint a terület talaja víztaszító. Ennek következtében a Mini Disk Infiltorméterrel mért hidraulikus vezetőképesség értékeket bizonyos esetekben korrigálnunk kellett, ugyanis néhány víztaszító mérési pont (WDPT $>5 \mathrm{~s}$ ) esetében csak késleltetve indult meg a beszivárgás. A korrigálás során a $\mathrm{K}_{\mathrm{S}}$ kiértékeléséhez nem a teljes mérési adatsort vettük alapul, hanem csak a beszivárgás megindulása utáni adatokat ábrázoltuk az idő gyökének függvényében (14. ábra). A két számítási módszer eredményei között jelentkező különbségeket a 22. melléklet mutatja be.

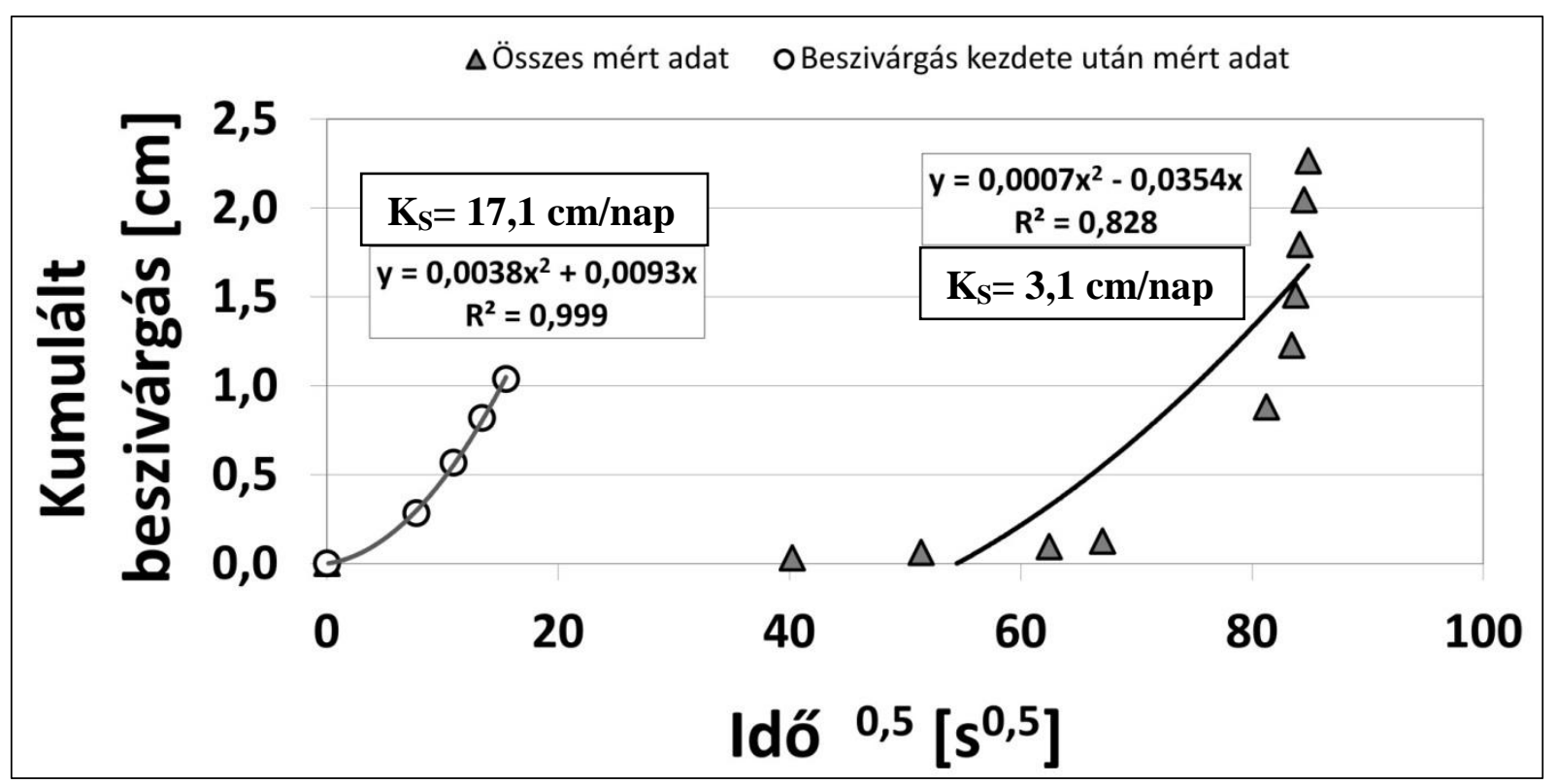

14. ábra: Kumulált beszivárgás mértéke az idő gyökének függvényében, az összes mért adat (szürke háromszög) és az intenzív beszivárgás megindulása után mért adatok (üres kör) esetén és az azokból meghatározott $\mathrm{K}_{\mathrm{S}}$ értékek Csólyospáloson 2012.05.03-án.

Jól látható, hogy akár nagyságrendnyi különbséget is okozhat a $\mathrm{K}_{\mathrm{S}}$ értékében, ha a hagyományos módszer helyett a helyszíni talajtulajdonságokat is számításba vevő módosított eljárást alkalmazzuk. A beszivárgás elindulása esetenként néhány percet vett igénybe, mely után gyors ütemben megindult az infiltráció, de néhány esetben 50-60 percet is várnunk kellett. A késleltetett beszivárgás egyértelmü bizonyítéka a csólyospálosi talaj víztaszító jellegének. 


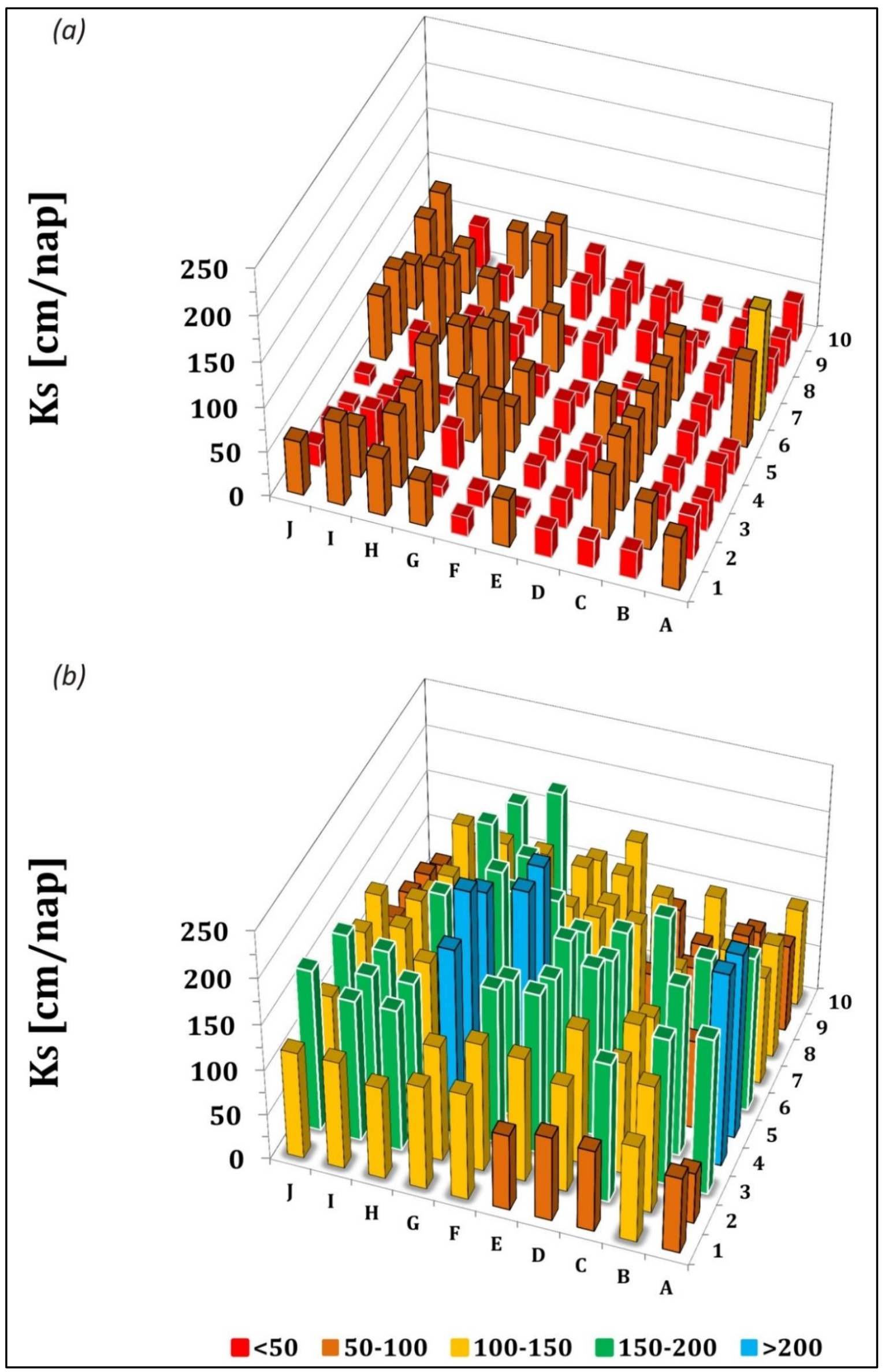

15. ábra: A vízvezető képesség térbeli heterogenitása Csólyospálos (a) és Örbottyán (b) mintaterületén, 2012. május 3-án (a) és 2012. május 31-én (b). 
A csólyospálosi hidraulikus vezetőképesség eredmények alapján elmondható, hogy nagymértékü a terület térbeli heterogenitása (15. ábra), ezért elképzelhető, hogy a MDI korongja részben, vagy teljes egészében víztaszító folton helyezkedett el. Ezért célszerü a kiértékelés során csak a homokra jellemző, intenzív beszivárgás kezdete után mért adatokat használni. Továbbá, ha egy terület jelentős heterogenitással rendelkezik, akkor az egyik helyröl elfolyó víz beszivárog egy közeli helyen, pl.: rések, növényi gyökerek, repedések mentén, így a területre érkező csapadék „ujjszerüen” (fingering flow) (Baker és Hillel, 1990; Kawamoto et al., 2004; Lichner et al., 2013) szivárog a mélybe, a beszivárgási zónák közt száraz lencséket hagyva. Ezek következtében durvább léptékben kisebb lehet a víztaszítás, mint a helyi értékek átlaga.

A csólyospálosi és az őrbottyáni mintaterületeken mért hidraulikus vezetőképesség értékek jelentősen eltérnek egymástól (15. ábra). Az őrbottyáni homoktalaj (15b. ábra) esetében az átlagos $\mathrm{K}_{\mathrm{S}}: 137,7 \mathrm{~cm} / \mathrm{nap}$, legnagyobb: 235,5 cm/nap és legkisebb beszivárgási értéke: 56,1 cm/nap (ld. 23. melléklet). A Mini Disk Infiltrométeres hidraulikus vezetőképesség értékek átlaga jó egyezést mutat Őrbottyán területén más módszerekkel mért korábbi $\mathrm{K}_{\mathrm{S}}$ adatokkal (Fodor et al., 2009; Fodor et al., 2011). Ez arra enged következtetni, hogy a MDI megbízhatóan alkalmazható az őrbottyáni mintaterületen a talaj hidraulikus vezetőképességének meghatározására.

A csólyospálosi homoktalajnál (15a. ábra) a Mini Disk Infiltrométerrel mért átlagos vízvezető képesség 46,6 cm/nap, a maximális: 124,4 cm/nap és a minimális értéke 7,6 cm/nap. A 100 mérésből több olyan vízvezető képesség értéket mértünk, melyek vályog, esetenként agyagos vályog talaj beszivárgási adataira jellemzőek (ld.: 16. ábra).

A mérési hiba lehetőségét kizárhatjuk, mivel a 7.2.1-es fejezetben bemutatott visszaülepedési kísérlet 5 mérési időpontja során szintén igen alacsony, homokra nem jellemző $\mathrm{K}_{\mathrm{S}}$ értékeket mértünk MDI-vel Csólyospáloson. A $100 \mathrm{~cm}^{3}$-es mintákból, laboratóriumban mért átlagos vízvezető képesség értéke viszont $576 \mathrm{~cm} / \mathrm{nap}$, mely egy, esetenként két nagyságrenddel nagyobb, mint az MDI-vel mért értékek. Bár Hunter és munkatársai (2011) szerint jól alkalmazható a Mini Disk Infiltrométer víztaszító talajoknál, azonban, a csólyospálosi homoktalaj esetében ennek ellentmondó eredményeket kaptunk.

A hidraulikus vezetőképesség értékek nagymértékü térbeli heterogenitása jelentősen befolyásolhatja a modell szimulációk eredményeit, esetenként hibás végeredményhez is vezethet. Ezért nem javasoljuk víztaszító homoktalajok esetében a minikorongos beszivárgásmérő alkalmazását a telítésközeli vízvezető képesség mérésére. 


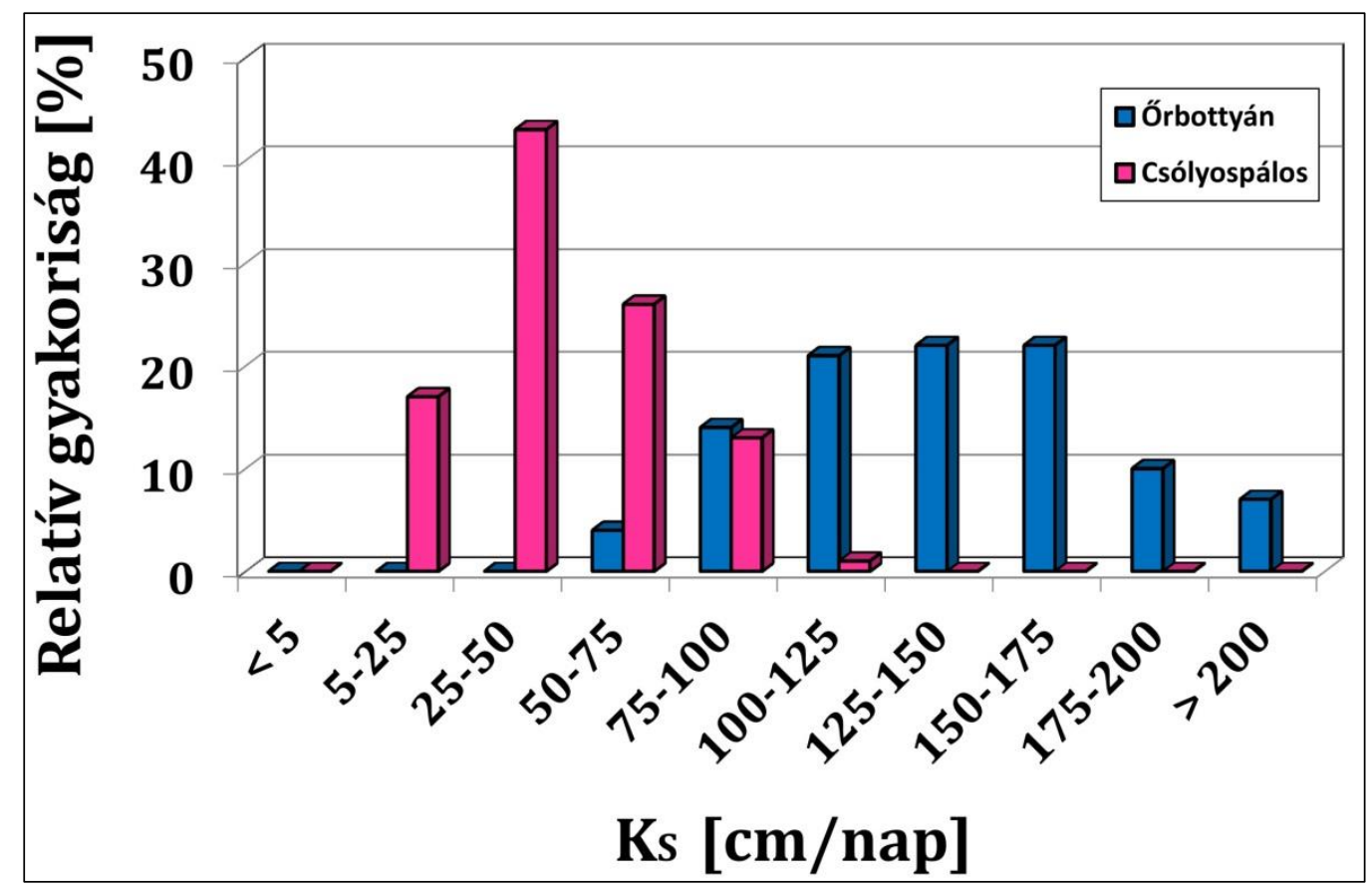

16. ábra: Az $1 \mathrm{~m}^{2}$-en mért hidraulikus vezetőképesség értékek relatív gyakorisága Örbottyánban (kék oszlop) és Csólyospáloson (rózsaszín oszlop).

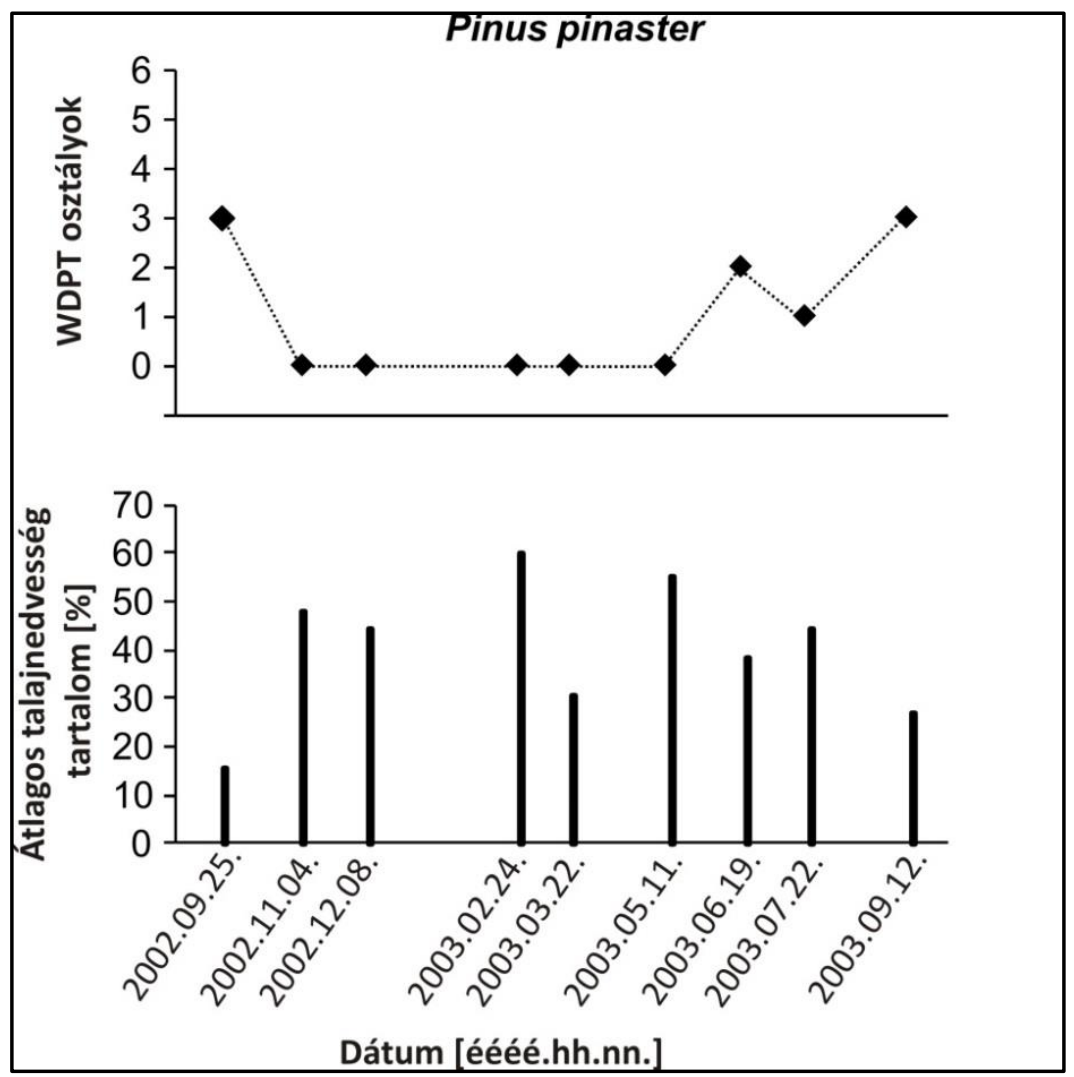

17. ábra: Az átlagos talajnedvesség és a WDPT osztályok a feltalaj időbeli változékonysága függvényében, tengerparti fenyő (Pinus pinaster) ültetvényben. (WDPT osztályok: 0:<5 s; 1: 5-60 s; 2: 60-600 s; 3: 600-3600 s; 4: 1-3 h; 5: 3-6 h; 6: >6 h). (Ábra forrása: Rodríguez-Alleres és Benito, 2011.)

További problémát idézhet elö, hogy bizonyos esetekben a talajok víztaszításának térbeli változatossága megközelítheti az időbeli változékonysága mértékét. Csólyospáloson $1 \mathrm{~m}^{2}$-en 
belül 3 nagyságrendnyi különbség mutatkozott a talajnedvesíthetőség értékei között. Hasonló mértékü változékonyságot állapított meg Rodrígez-Alleres és Benito (2011) az 1 év során mért WDPT mérési adatsorában (17. ábra). A fentiek értelmében a térbeli változatosság megközelítheti az időbeni változékonyságot. Így felmerül a kérdés, hogy mit is mérünk valójában: idő-, vagy térbeli heterogenitást?

\subsection{3. $\quad A K_{S}$ érték mintaméret-függése}

Az őrbottyáni homoktalajon mért Booltink-féle (1991) $5650 \mathrm{~cm}^{3}$-es minták vízvezető képesség értékei szignifikánsan különböztek a hagyományos $100 \mathrm{~cm}^{3}$-es eljárással meghatározott $\mathrm{K}_{\mathrm{S}}$-ektől (4. táblázat). A jellemzően homoktalajok esetében jelentkező falhatás szignifikáns különbséget okozhat, ezért fontos kiküszöbölnünk ezt a mérési eredményt befolyásoló tényezőt. Lényegesen csökkenthetjük a falhatás mértékét, ha a kis mintavevő henger belső falát szilikon zsírral kikenjük a mintavételt megelőzően (Fodor et al., 2009), mely eredményeképp átlagosan 74,6 cm/nap beszivárgást kaptunk. A falhatás kiiktatásával kapott érték nem mutat szignifikáns különbséget az etalonnak tartott nagy hengeres mintavétel eredményeinek átlagától. Tehát homoktalaj esetén pontosabb eredményt kaphatunk, ha a 100 $\mathrm{cm}^{3}$-es mintavevő henger belső falát - a nagy hengeres módszerhez hasonlóan — kizsírozzuk (Fodor et al., 2009, 2011).

\begin{tabular}{|c|c|c|c|}
\hline \multirow{2}{*}{ Őrbottyán } & \multirow{2}{*}{$\mathrm{K}_{\mathrm{S}} \mathrm{cm} / \mathrm{nap}$} & \multicolumn{2}{|c|}{$\mathrm{K}_{\mathrm{S}} \mathrm{cm} / \mathrm{nap}$} \\
\hline & & Átlag & Szórás \\
\hline \multirow{5}{*}{$\begin{array}{l}\text { Kis minta } \\
100 \mathrm{~cm}^{3}\end{array}$} & 144,6 & \multirow{5}{*}{146,7} & \multirow{5}{*}{21,9} \\
\hline & 154,4 & & \\
\hline & 160,2 & & \\
\hline & 109,9 & & \\
\hline & 164,3 & & \\
\hline \multirow{5}{*}{$\begin{array}{l}\text { Nagy minta } \\
5650 \mathrm{~cm}^{3}\end{array}$} & 116,2 & \multirow{5}{*}{94,0} & \multirow{5}{*}{22,5} \\
\hline & 77,8 & & \\
\hline & 97,8 & & \\
\hline & 64,5 & & \\
\hline & 113,5 & & \\
\hline
\end{tabular}

4. táblázat: A kis- és nagypatronos minták $\mathrm{K}_{\mathrm{S}}$ értékeinek összehasonlítása, Örbottyánban (Fodor et al., 2011).

A nagyhörcsöki mintaterületen mért nagypatronos minták $\mathrm{K}_{\mathrm{S}}$ értékei jelentősen különböztek a $100 \mathrm{~cm}^{3}$-es minták telítési vízvezető képesség értékeitől (5. táblázat). Szignifikáns különbség van a $100 \mathrm{~cm}^{3}$-es és $5650 \mathrm{~cm}^{3}$-es minták hidraulikus vezetőképesség szórás értékei között (Fodor et al., 2011) vályog fizikai féleségű talajon. 


\begin{tabular}{|c|c|c|c|}
\hline \multirow{2}{*}{ Nagyhörcsök } & \multirow{2}{*}{$\mathrm{K}_{\mathrm{S}} \mathrm{cm} / \mathrm{nap}$} & \multicolumn{2}{|c|}{$K_{S} \mathbf{c m} /$ nap } \\
\hline & & Átlag & Szórás \\
\hline \multirow{5}{*}{$\begin{array}{l}\text { Kis minta } \\
100 \mathrm{~cm}^{3}\end{array}$} & 23,3 & \multirow{5}{*}{62,4} & \multirow{5}{*}{91,2} \\
\hline & 225,1 & & \\
\hline & 29,6 & & \\
\hline & 10,5 & & \\
\hline & 23,5 & & \\
\hline \multirow{5}{*}{$\begin{array}{l}\text { Nagy minta } \\
5650 \mathrm{~cm}^{3}\end{array}$} & 89,2 & \multirow{5}{*}{94,6} & \multirow{5}{*}{31,4} \\
\hline & 140,4 & & \\
\hline & 105,5 & & \\
\hline & 73,7 & & \\
\hline & 59,1 & & \\
\hline
\end{tabular}

5. táblázat: A kis- és nagypatronos minták $\mathrm{K}_{\mathrm{S}}$ értékeinek összehasonlítása, Nagyhörcsökön (Fodor et al., 2011).

A szurdokpüspöki agyag talajon szintén összehasonlítottuk a hagyományos $100 \mathrm{~cm}^{3}$ es hengerrel mért $\mathrm{K}_{\mathrm{S}}$ eredményeket (6. táblázat) a nagypatronos telítési vízvezető képesség értékekkel. A $100 \mathrm{~cm}^{3}$ minták esetén átlagosan 112,8 cm/nap hidraulikus vezetőképesség értéket mértünk (6. táblázat), mely szignifikánsan nagyobb, mint a nagypatronos mérések $67,1 \mathrm{~cm} /$ nap-os átlagértéke. A fentiek értelmében, agyag területen mért $\mathrm{K}_{\mathrm{S}}$ értékekben szignifikáns különbséget okozhat a mintavételezési egységek egy nagyságrendnyi különbsége. A számottevő különbségek hátterében az agyag talajra jellemző makropórus áramlás állhat, mely megnövelheti a $\mathrm{K}_{\mathrm{S}}$ mérési bizonytalanságát. A telítési vízvezető képesség szórás értéke szignifikánsan kisebb a nagy minták esetében, mivel a nagyobb felület miatt, kisebb az egyes mintákon mért $K_{S}$ és az átlag közötti eltérés várható értéke.

\begin{tabular}{|c|c|c|c|}
\hline \multirow{2}{*}{ Szurdokpüspöki } & \multirow{2}{*}{$\mathrm{K}_{\mathrm{S}} \mathrm{cm} / \mathrm{nap}$} & \multicolumn{2}{|c|}{$K_{S}$ cm/nap } \\
\hline & & Átlag & Szórás \\
\hline \multirow{5}{*}{$\begin{array}{l}\text { Kis minta } \\
100 \mathrm{~cm}^{3}\end{array}$} & 17,7 & \multirow{5}{*}{112,8} & \multirow{5}{*}{195,8} \\
\hline & 460,2 & & \\
\hline & 67,9 & & \\
\hline & 11,3 & & \\
\hline & 6,9 & & \\
\hline \multirow{5}{*}{$\begin{array}{c}\text { Nagy minta } \\
5650 \mathrm{~cm}^{3}\end{array}$} & 61,6 & \multirow{5}{*}{67,1} & \multirow{5}{*}{70,8} \\
\hline & 0,2 & & \\
\hline & 0,4 & & \\
\hline & 110,5 & & \\
\hline & 163,0 & & \\
\hline
\end{tabular}

6. táblázat: A kis- és nagypatronos minták $\mathrm{K}_{\mathrm{S}}$ értékeinek összehasonlítása, Szurdokpüspökiben. 
Homok és vályog talajokhoz hasonlóan, agyag fizikai féleségü talaj vizsgálata során is szignifikáns különbséget tapasztaltunk a $100 \mathrm{~cm}^{3}$-es és $5650 \mathrm{~cm}^{3}$-es mintákon mért telítési vízvezetők képesség átlag értékében. Az eredmények arra engednek következtetni, hogy jelentős léptékfüggés van a két telítési vízvezető képesség meghatározó módszer között. A szurdokpüspöki agyag talaj esetében a $\mathrm{K}_{\mathrm{S}}$ mérés bizonytalanságát a makropórus áramlás (pl. gyökér és/vagy gilisztajárat) jelentősen megnövelte.

A nagypatronos minták esetében kisebb a szórás értéke és a mérési bizonytalanság mind a három vizsgált talajtípusnál. Tehát, a Booltink-féle (1991) nagypatronos eljárás megbízhatóbb eredményt szolgáltat, a nagyobb térfogat, a garantált telítettség és a kontrollált peremfeltételek következtében, mint a hagyományos $100 \mathrm{~cm}^{3}$-es módszer.

\subsection{A 4Mx és a HYDRUS-1D MATEMATIKAI MODELLEK ALKALMAZÁSA}

\subsubsection{A léptékfüggés megjelenése a meteorológiai adatsorok felhasználásakor}

A 18. ábra a mért („hőmérséklet napi menete-1”) és a 4Mx modellel szimulált („hőmérséklet napi menete-2”) léghőmérséklet értékeket ábrázolja az idő függvényében. A 'hőmérséklet napi menete-1' jelöli az 5 perces felbontásban mért léghőmérséklet napi változását, míg a 'hőmérséklet napi menete-2' a napi maximum és minimum alapján számított léghőmérsékleteket, melyek napi menetét szinuszfüggvénnyel írja le a modell. A Tb a bázis hőmérsékletet jelöli, amely kukorica esetében $8{ }^{\circ} \mathrm{C}$. Grafikus értelemben a görbék és a Tb egyenes közé eső terület a két féle módszerrel kiszámítható aznapra vonatkozó hőidő. A 18. ábrán bemutatott nap egy szép példa arra, hogy ha valamilyen oknál fogva, például jelen esetben feltételezhetően egy 12-15 óra közötti felhőátvonulás miatt, a hőmérséklet tényleges menete eltér a feltételezettől, akkor a napi 2 hőmérséklet adatból számított, illetve az 5 perces mérésekből álló görbe alatti területek lényegesen eltérhetnek.

Tehát a modell által számolt hőfoknap egy idealizált esetre vonatkozik, ahol nem jelennek meg a finomabb felbontásban érzékelhető különbségek (pl.: felhőátvonulás). A bemutatott példa alapján a tényleges hőidő értékét alulbecsülhetjük, ha nem megfelelő mérési felbontást választunk.

A továbbiakban megvizsgáltuk, hogy egy hosszabb időszak alatt (2010.06.02. 2010.06.14.), hogyan alakul a kumulált különbség az 5 perces mérések és a napi léptékü hőmérsékleti adatok alapján számított hőösszegek között. A 19. ábrán jól látható, hogy 2010.06.02. és 2010.06.12. között, 10 nap leforgása alatt közel 20 hőfoknapnyi különbség adódott a két számítási módszer között, mely ebben az időszakban több mint 1 napnyi különbséget jelent, azaz több mint $10 \%$-os eltérés van a két módszer eredményei között (Sándor et al., 2010). 


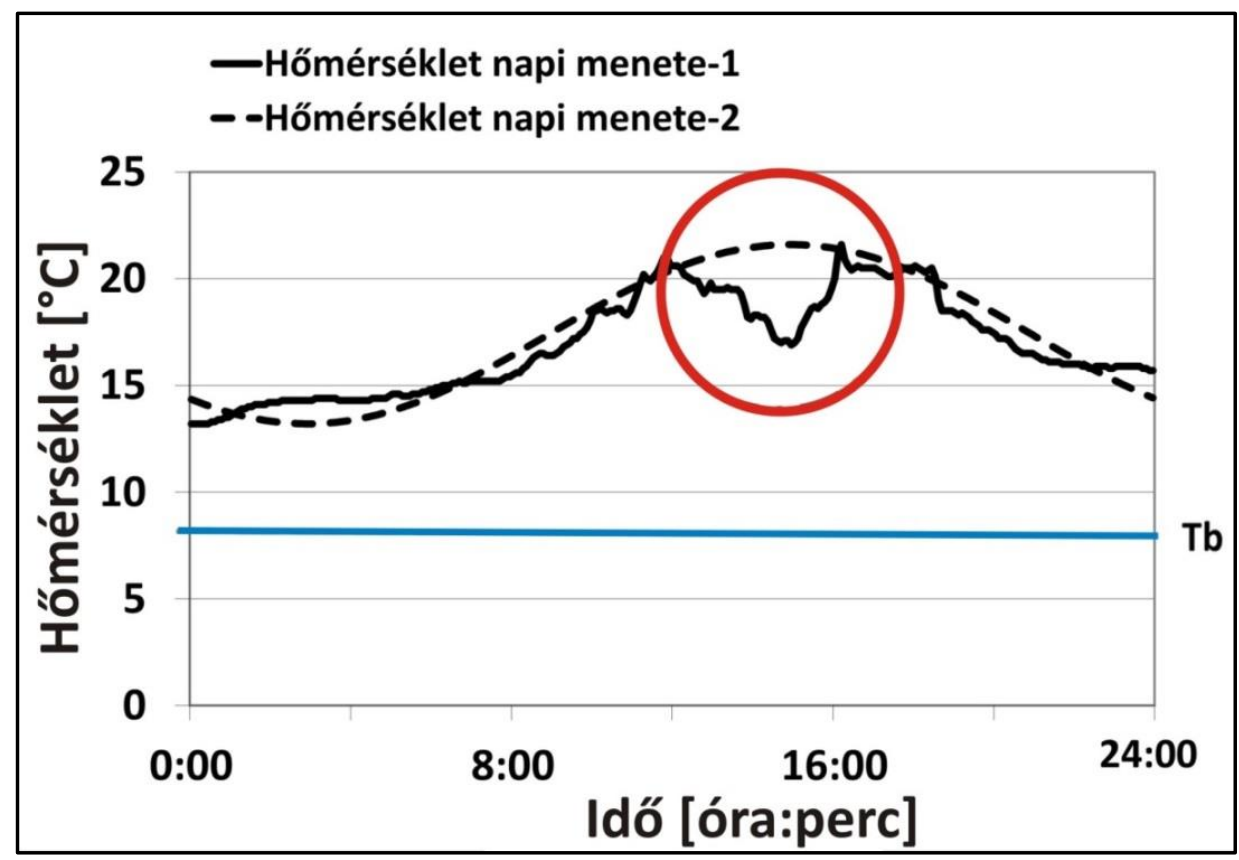

18. ábra: A hőmérséklet napi menete 2010.04.25-én Örbottyánban. A „hőmérséklet napi menete-1” jelöli az 5 perces felbontásban mért hőmérsékleti értékeket, míg a „hőmérséklet napi menete-2” a modell által számított hőmérsékletet mutatja. Tb: bázishőmérséklet (kék vonal). Piros kör: a feltételezhető felhőátvonulás időszaka.

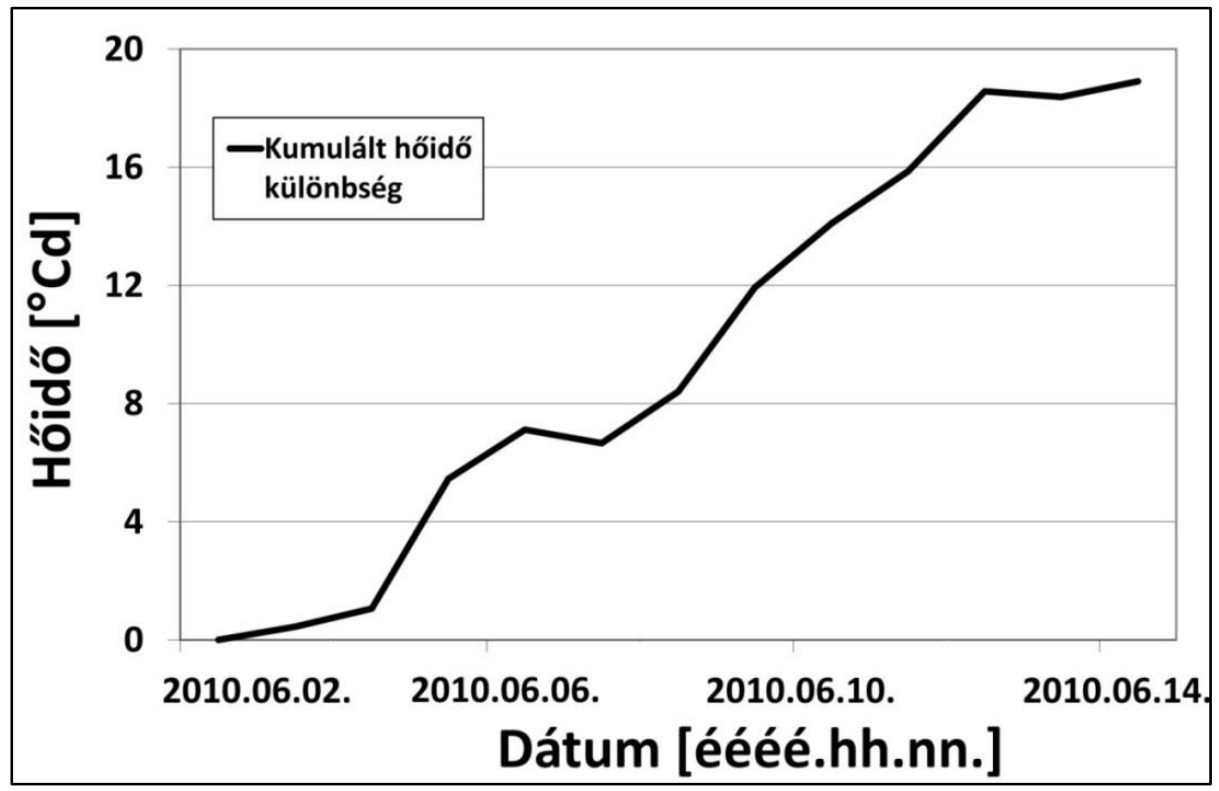

19. ábra: A vizsgált hőidő számítási módszerek összehasonlítása 2010.06.02. és 2010.06.14. között Örbottyánban.

A teljes vegetációs időszakot tekintve, akár több napnyi különbség is származhat, pusztán az eltérő időléptékü adatok használatából. Ez jelentős modellezési hibát eredményezhet, mivel a termésszimulációs modellek a napi két hőmérséklet adatból meghatározott hőösszegek alapján számítják ki a növények fenológiai fejlődésének ütemét (Sándor et al., 2010). 


\subsubsection{Eltérő térléptékű modellekkel számított talajhőmérséklet értékek össze- hasonlítása}

A talajhőmérséklet modellezését megelőzően fontos, hogy bemutassuk a különböző és azonos növénytermesztési kezelések hatását a különböző mélységekben mért talajhőmérsékleti értékekre.

A mütrágyázott 8. parcella növényzete jobban fejlett volt a kiválasztott időpontban, 2011. július 14-én, a levélfelület index értéke 3,1, míg a 2. parcella növényzetének a LAI értéke 0,9 volt (20. ábra). A talajhőmérséklet maximumában több mint $5{ }^{\circ} \mathrm{C}$ különbséget mértünk a két parcella $5 \mathrm{~cm}$-es mélységében. A $20 \mathrm{~cm}$-es talajmélységben az észlelt különbség szintén jelentős, $3,8^{\circ} \mathrm{C}$ volt. Ebben a mélységben a legmagasabb talajhőmérséklet a léghőmérséklet maximumánál 6 órával később, — naplementekor - jelentkezett. A $60 \mathrm{~cm}$ es mélységben a talaj hőmérsékletváltozása igen csekély mértékü, de jól látható (20. ábra), hogy a mütrágyázott parcella fejlettebb növényzete alatt kevésbé melegedett fel a talaj.

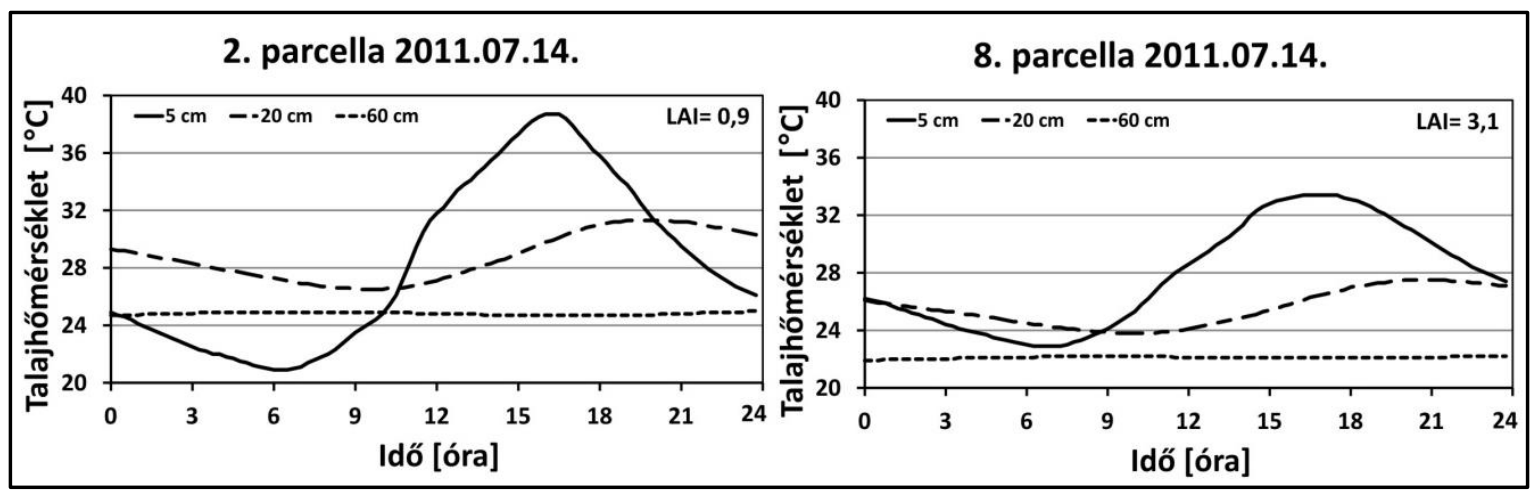

20. ábra: A talajhőmérséklet napon belüli változása a LAI függvényében $5 \mathrm{~cm}$-es (folytonos vonal), $20 \mathrm{~cm}$-es (szaggatott vonal) és $60 \mathrm{~cm}$-es (pontozott vonal) mélységekben az őrbottyáni 2. mintaterület kontroll (2.) és mütrágyázott (8.) parcelláin 2011.07.14-én.

Legjelentősebb eltérést az örbottyáni mütrágyázott, nem öntözött kezelések $5 \mathrm{~cm}$-es mélységben mért talajhőmérséklet-dinamikában mutattunk ki (21. ábra), míg a $60 \mathrm{~cm}$-es mélységben nem volt kimutatható különbség. A 2011-es vegetációs időszak során az 1. parcella maximális LAI értéke 2,4 volt. A jelentősebb növényborítottság következtében a 8 . parcella mérsékeltebben melegedett fel $5 \mathrm{~cm}$ mélyen.

Lényeges eltérés figyelhető meg az 1. és 8. parcellán mért téli talajhőmérséklet értékekben (21. ábra). A 8. parcella minimum értéke a vizsgált időszakban $-1,4{ }^{\circ} \mathrm{C}$ volt, míg az 1. parcellán $-5,3{ }^{\circ} \mathrm{C}$-ot mértünk. Az eltérés valószínü oka, hogy a téli időszakban a talaj hőmérsékletét alapvetően a hóréteg kialakulása befolyásolja. A vizsgált parcellák között szintkülönbség figyelhető meg és a mintaterület a 8. parcella irányába lejt. A lejtés, illetve a 
szél hatásának következtében a 8. parcella fölött vastagabb hóréteg keletkezhetett, mint az 1. parcellán. A hóréteg kis hővezető képessége folytán mérsékli a talaj lehülését a hótakaró alsó határán (Sándor és Fodor, 2012a; Sándor et al., 2013).

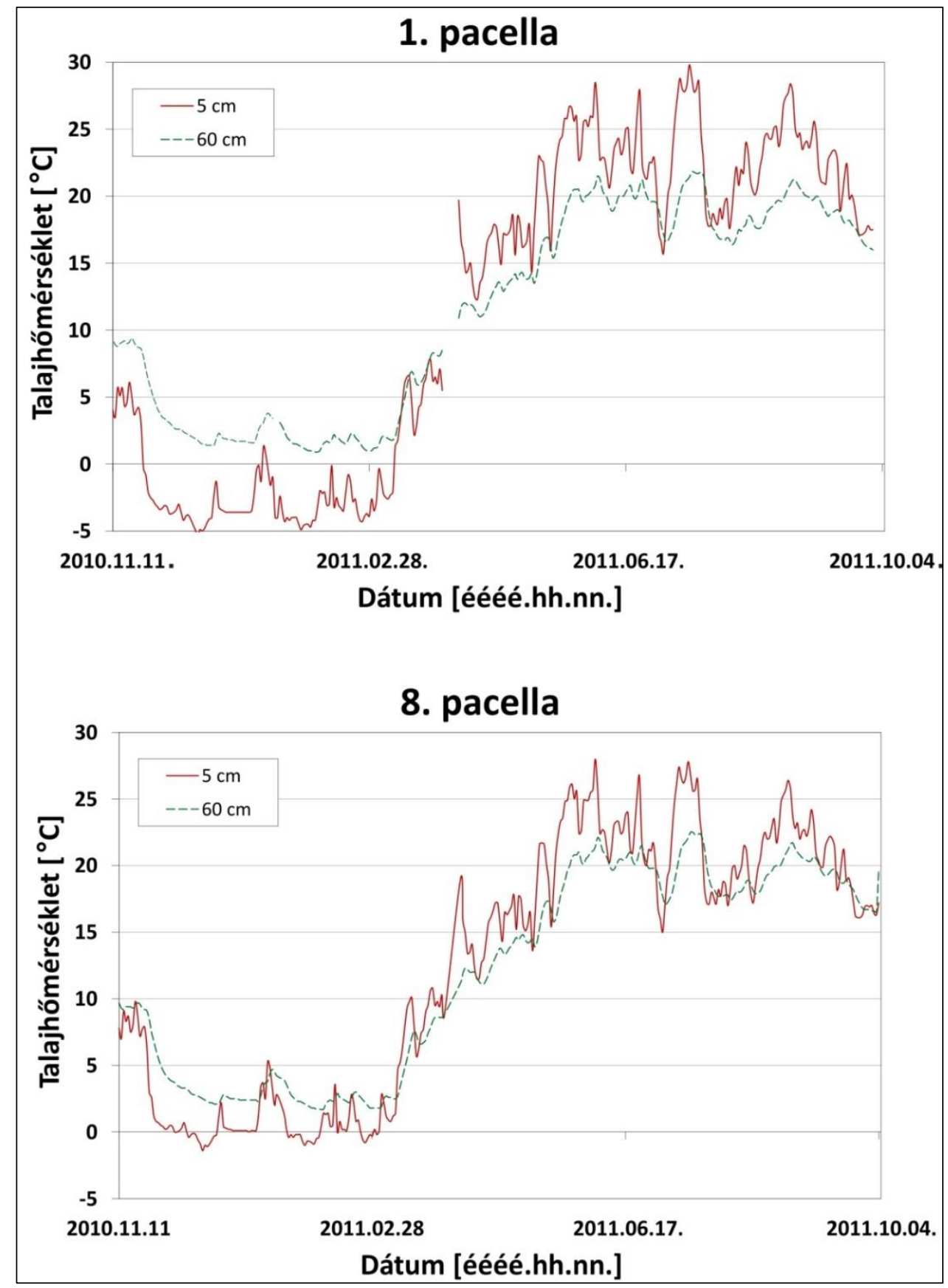

21. ábra: A talajhőmérséklet dinamikája $5 \mathrm{~cm}$-es (folytonos piros vonal) és $60 \mathrm{~cm}$-es (szaggatott zöld vonal) mélységekben, az őrbottyáni 2. mintaterület mütrágyázott (1. és 8.) parcelláin 2010.11.11. és 2011.10.04. között.

A fentiek értelmében a levélfelület index nagyon fontos befolyásoló tényezője lehet a szimulált talajhőmérséklet értékeknek, ugyanis a LAI hatása egyértelműen kimutatható a talaj hőmérsékletének változásában (20. és 21. ábra) különböző és azonos kezelések esetén is. A növényzet fejlettségi állapota befolyásolja a talajhőmérséklet dinamikáját, azáltal, hogy 
csökkenti az átlagos talajhőmérsékletet és a szélsőértékeket is, ezért a LAI figyelembevétele fontos a talaj hőmérsékletének modellezése során.

Ezért lényegesnek tartottuk, hogy az alkalmazott modellünk jól kövesse a LAI értékének változását a modellezett vegetációs időszakok alatt. A 4Mx modell-paramétereinek kalibrálása során inverz módszert alkalmaztunk (Soetaert és Petzoldt, 2010) azért, hogy a szimulált LAI értékek összhangban legyenek a mért értékekkel (22. ábra).

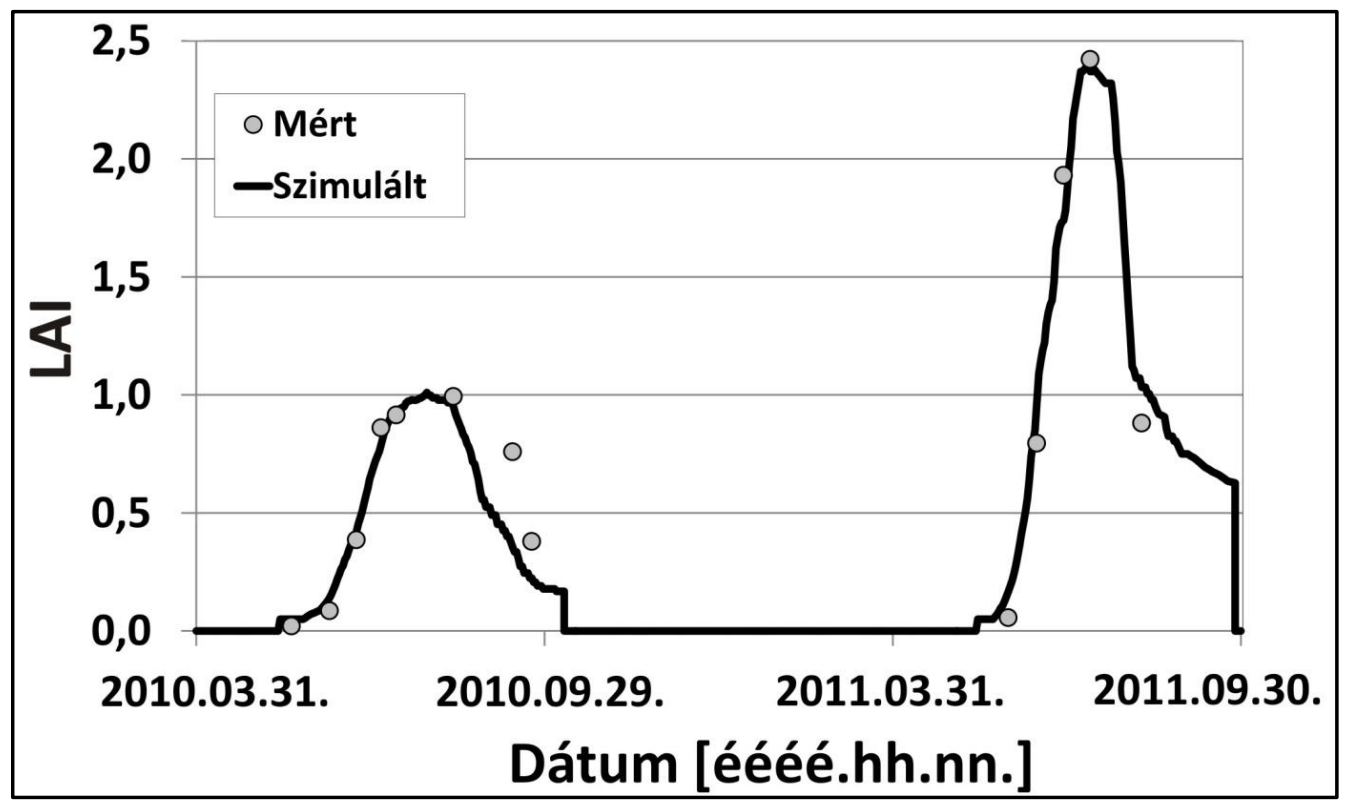

22. ábra: A mért (szürke pontok) és modellezett (folytonos vonal) levélfelület értékek menete az őrbottyáni 2. mintaterület mütrágyázott (1.) parcelláján, 2010.03.31. és 2011.09.30. között.

Eredendően a felhasználók nem tudják módosítani a 4Mx talajhőmérséklet leíró 4. és 5. egyenletét, így nem kalibrálható, azonban elvárható, hogy minden talajtípus esetén megbízható eredményt szolgáltasson. Ezért a hőforgalmat leíró egyenlet (4. egyenlet) egy egyszerü módosítása javasolt, hogy a felhasználónak nagyobb rugalmasságot adva, lehetőséget nyújtson hely specifikus kalibrációra (Sándor és Fodor, 2012a):

$T_{\text {soil }}^{i}(x)=\left[T_{\text {avg }}+\frac{T_{a m p} \cdot \cos \left[0,0174 \cdot(i-I)+x \cdot f_{1}\left(\Theta_{a v g,} B D_{a v g}\right)\right]}{2}+F_{D 5}\right] \cdot e^{c \cdot x \cdot f_{2}\left(\Theta^{i}{ }_{a v g}, B D_{a v g}\right)}$

A c paraméter (23. egyenlet) módosításával beállítható a mélyebb talajrétegeket elérő hőenergia mennyisége. Ez a paraméter nem csupán fizikai jellemző, hanem magában foglalja a talaj szerves anyagának, szerkezetének és más talaj specifikus tényezők hőáramlásra gyakorolt hatását is. 
A továbbiakban az őrbottyáni mintaterületen mért talajhőmérséklet értékeket hasonlítottuk össze a centiméteres felbontású HYDRUS-1D és a deciméteres felbontású 4Mx és módosított 4Mx modellezett eredményeivel (23. ábra).

$\mathrm{Az}$ újonnan bemutatott 23. egyenlet kalibrációjánál $\mathrm{c}=4$-es értéket állítottunk be, mely modellezett eredményei a módosított 4Mx oszlopban olvashatók (23. ábra). Az ábrán jól látható, hogy a 4Mx modell lényegesen alulbecsli a mélyebb rétegek hömérsékletét, különösen 2011-ben. A 24. ábrán bemutatott hibamutatók alapján a módosított 4Mx jobban közelíti a talajhőmérséklet értékét, mint az eredeti 4Mx, kiváltképp a mélyebb rétegekben.

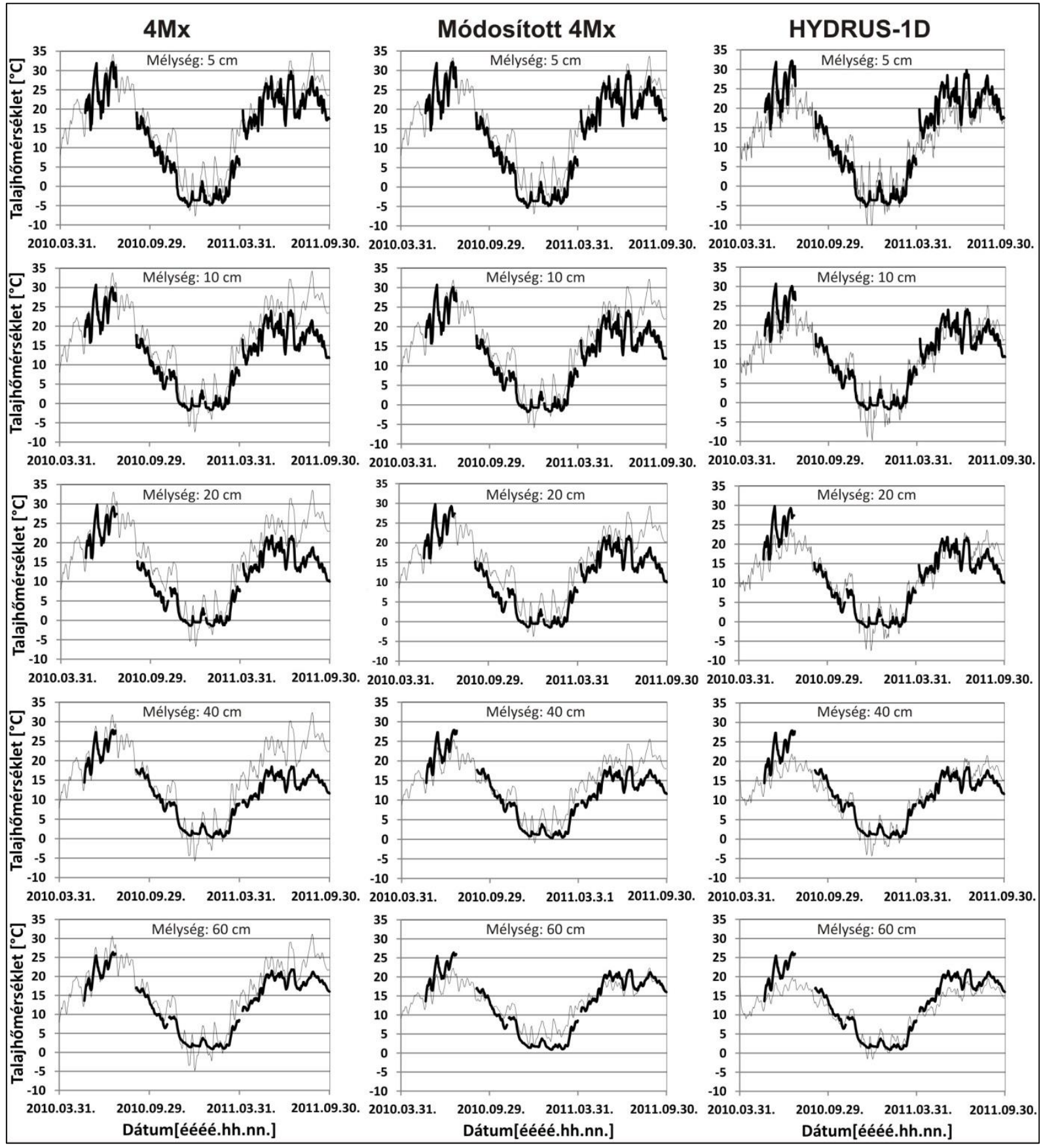

23. ábra: A különböző mélységű mért (vastag vonal) és szimulált (vékony vonal) talajhőmérséklet értékek menete az örbottyáni 2. mintaterület mütrágyázott (1.) parcelláján 2010.03.31 - 2011.09.30. között. 


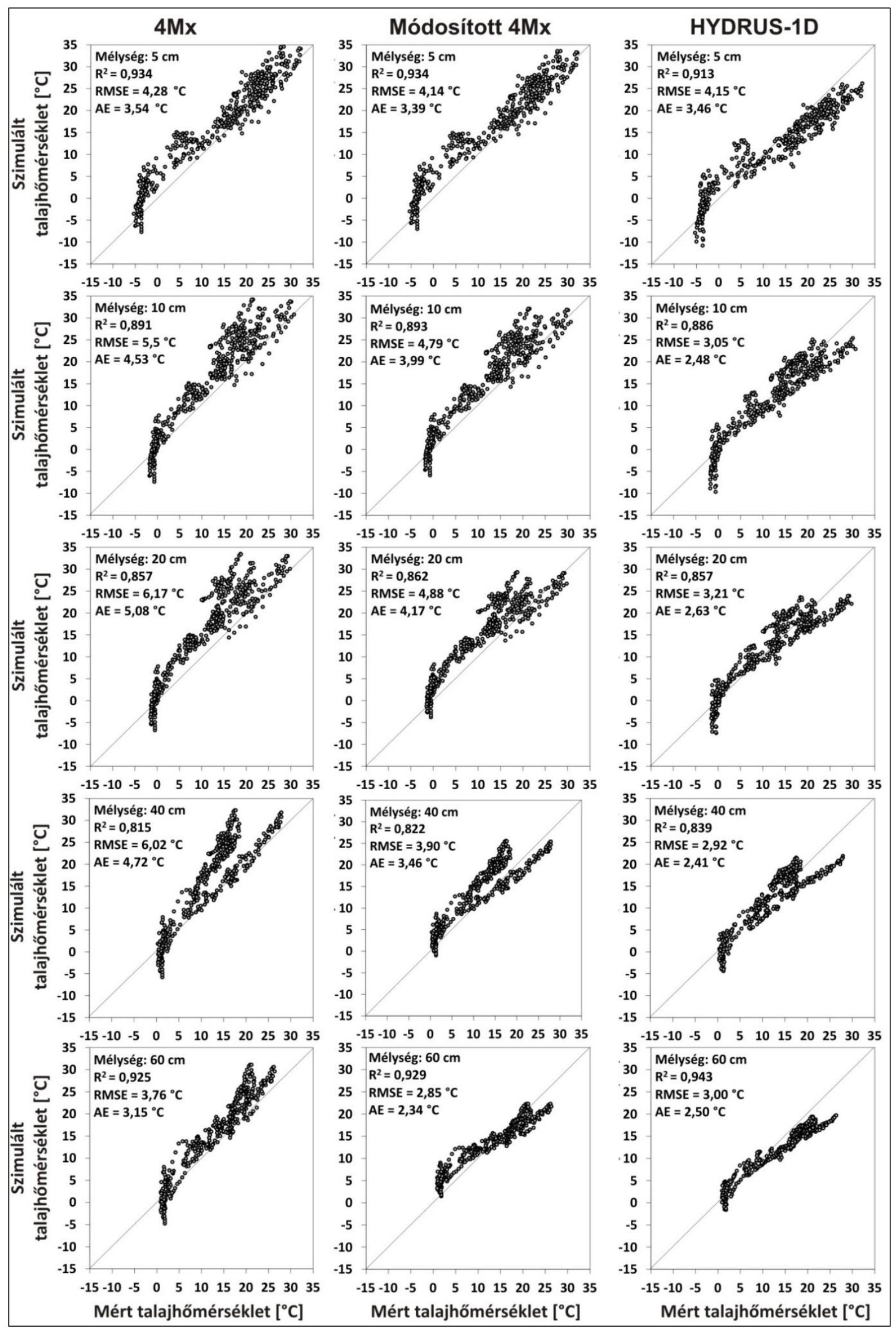

24. ábra: A mért és szimulált talajhőmérséklet értékek mélység szerinti összehasonlítása. 
A HYDRUS-1D modellezett értékei jobban illeszkednek a mért értékekhez, de a feltalaj hőmérsékletét ez a modell is jelentősen alulbecsli a téli időszakban. A szimulált felső $(5 \mathrm{~cm}$ es) és alsó (60 cm-es) rétegek hőmérsékleti hibamutatói hasonló értékeket mutatnak, mint a módosított 4Mx modellezett eredményei. A HYDRUS-1D egyértelmüen alulbecsli az alsóbb rétegek hőmérsékletét fagyhatás esetén. Például 2010.12.27. - 2011.01.04. között az átlagos léghőmérséklet $-7,1{ }^{\circ} \mathrm{C}$ volt, addig az $5 \mathrm{~cm}$-en mért talajhőmérséklet $-3,4{ }^{\circ} \mathrm{C}$ volt, a HYDRUS-1D viszont átlagosan $-6,5^{\circ} \mathrm{C}$-ot szimulált.

Az 5 cm-es mélységben mért talajhőmérséklet értéke nem haladta meg a $-5{ }^{\circ} \mathrm{C}$-ot, annak ellenére, hogy az átlagos napi hőmérséklet tartósan $-7{ }^{\circ} \mathrm{C}$ alatt maradt (néhány nap esetében a napi minimum $-15^{\circ} \mathrm{C}$ alatt volt) 2010 decemberében és 2011 januárjában. Ezen téli időszak alatt jelentős hó borítás volt a vizsgált területen, melynek következtében lecsökkent a fagyhatás mértéke a talajban (Goodrich, 1982). Azonban, mind a két modelltípus alulbecsli a téli időszak aktuális talajhőmérsékletét és felülbecsli a hőmérsékleti ingadozás mértékét, így a modellek nem szimulálták megfelelően a hóréteg szigetelő hatását. Annak ellenére, hogy a 4Mx és HYDRUS-1D modellek hónak definiálják a $0{ }^{\circ} \mathrm{C}$ alatt hulló csapadékot, egyik modell sem számítja ennek az izoláló hatását, például azáltal, hogy csökkentenék a hóréteg hővezető képességét.

$\mathrm{Az}$ eredeti 4Mx modell szimulált értékei jelentősen felülbecslik a nyári talajhőmérséklet értékeit, míg a téli időszakban alulbecsli azt. Például $60 \mathrm{~cm}$-es mélységben a számított talajhőmérséklet $-5{ }^{\circ} \mathrm{C}$ alatt volt, szemben a mért $+2{ }^{\circ} \mathrm{C}-\mathrm{kal}$. A módosított $4 \mathrm{Mx}$ modell négyszer kevesebb hőenergiát közvetített a mélyebb rétegek felé így alacsonyabb hőmérsékletet szimulált. A hőmérséklet átlagos hibája közel 70 \%-kal csökkent az eredeti 4Mx modellezett eredményeihez képest 40 és $60 \mathrm{~cm}$-es mélységekben.

HYDRUS-1D modellel számított talajhőmérséklet értékek jobban illeszkedtek a mért értékekhez. Azonban a 4Mx szimulációihoz jelentősen kevesebb peremfeltétel illetve paraméter megadására volt szükségünk. Például a 4Mx modell leegyszerüsített módon számítja a kapilláris vízemelést, de számítja a levél felület fejlődését is, míg a HYDRUS-1D számára, ez utóbbit, mint bemenő adat szükséges megadnunk. Továbbá a HYDRUS-1D szimulációihoz néhány, talajra vonatkozó hőtulajdonság megadása is szükséges, mint például a hővezető képesség, melyet a talaj szemcseösszetételéből becsültünk. A HYDRUS-1D jelentős input igénye következtében a modellezők becslő eljárásokkal állapíthatják meg a szükséges, de rendelkezésre nem álló paramétereket, így csökkentve a modell pontosságát. Annak ellenére, hogy a módosított 4Mx modell számításaihoz jelentősen kevesebb peremfeltétel, illetve paraméter megadása szükséges, mint a HYDRUS-1D hidrológiai modell 
esetében, nincs szignifikáns különbség a modellezett talajhőmérséklet értékekben. Így javasolom az egyszerübb számítási elvü, módosított 4Mx modell alkalmazását.

\subsubsection{Mért és szimulált talajnedvesség értékek összehasonlítása növénytermesztési kísérlet kezelésében}

$\mathrm{Az}$ őrbottyáni 2. mintaterület 2. parcelláján (kontroll) mért talajnedvesség értékeket hasonlítottuk össze a centiméteres és deciméteres felbontású HYDRUS-1D modellezett eredményeivel, ld.: 25. és 26. ábra, 24. és 25. melléklet. A modell kalibrációját a LAI értékekre végeztük el, hasonlóan az előző fejezetben bemutatotthoz.

A szimulált talajnedvesség értékek a 0-10 és 0-80 cm-es mélységben (ld.: 24. és 25. melléklet) közelítik legjobban a mért adatokat, mind a cm-es, mind pedig dm-es felbontás esetén. Azonban, extrém száraz $(\Theta<1 \%)$ feltalaj esetén felülbecslik a talajnedvesség értékét.

A modellezett értékek felülbecslik a 0-30 cm-es mélység nedvességtartalmát 2010. 04. 27. - 2010. 06.09. között (25. és 26. ábra), mely valószínü oka, hogy a mintaterületen termesztett kukorica több nedvességet vett fel a kikelést követően, mint amit a modell számított. 2011-es év ezen időszakában a modellezett értékek jó egyezést mutattak a mért értékekkel, mely lehetséges oka a csapadékosabb tavaszi időjárás, míg 2012 tavaszán a szimulált értékek alulbecslik a talajnedvesség értékét, így kimutatható egy évjárathatás. 2010. 11. 05. - 2010. 11.18. illetve 2012. 09.27. - 2012.12.18. között alulbecslik a modellezett eredmények a talajnedvesség értét, mely valószínü oka, hogy a kukorica betakarítását követően, illetve a visszamaradó gyökerek eltávolítása után lecsökkenhetett a 0-30 cm-es szint nedvességtartalma.

A szimulált talajnedvesség értékek felülbecslik a mért értékeket 30-60 cm-es és 60-80 cm-es mélységekben 2010.04.26. - 2010.06.23. között (25. és 26. ábra), mely valószínü oka, hogy a tavasszal jelentkező csapadéktöbblet egy részét a 0-30 cm-es zónában a kukorica növények felvették, így valójában kevesebb víz szivároghatott a 30-60cm-es zónába. 2010 tavaszát követően, illetve 2011-ben a modellezett talajnedvesség értékek jól közelítették a mért értékeket, azonban a 2012-es évben alulbecslik. 


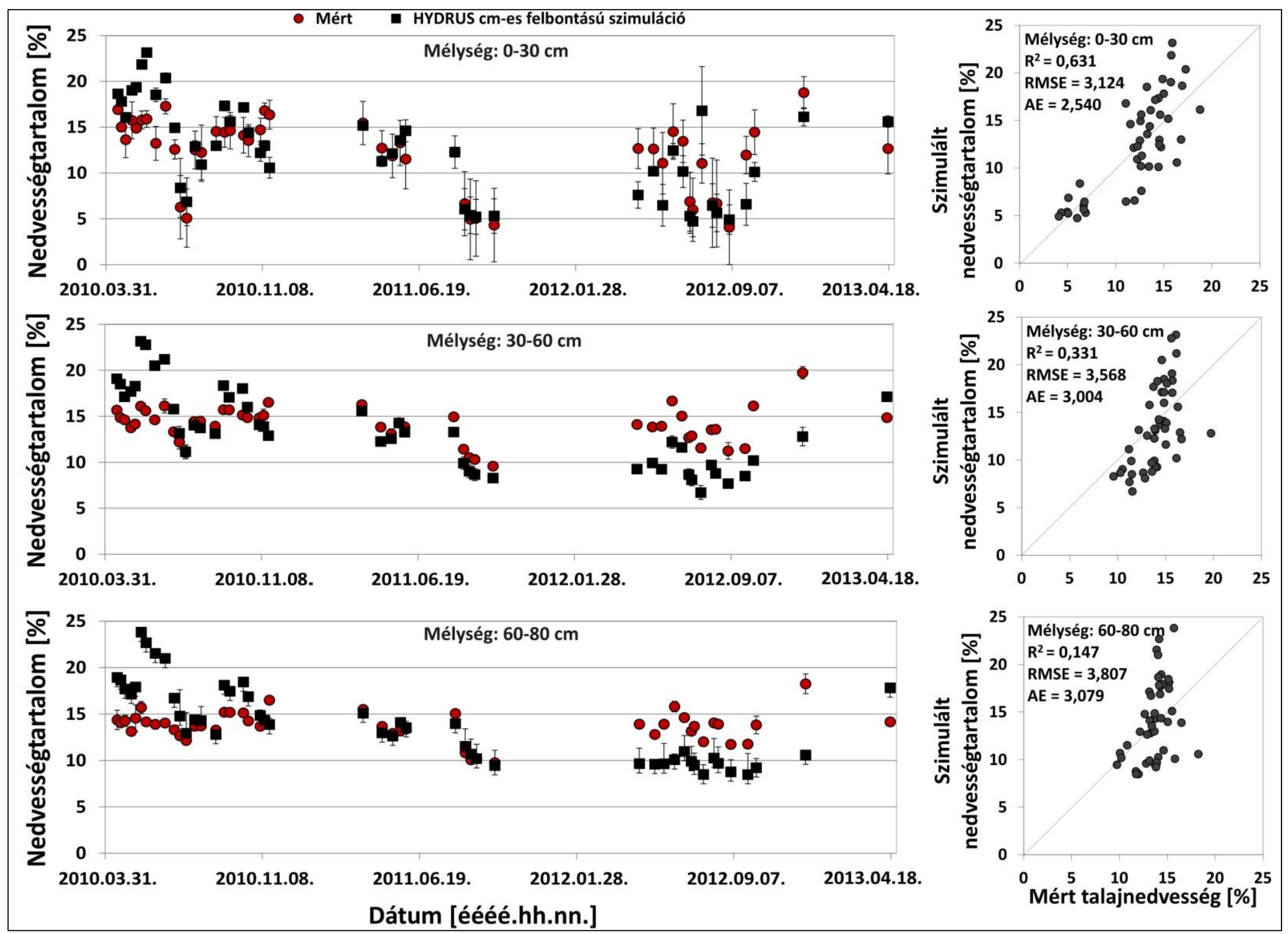

25. ábra: Különböző mélységben mért (piros kör) és centiméteres felbontású HYDRUS-1D modellel szimulált (fekete négyzet) talajnedvesség értékek változása és azok hibamutatói az örbottyáni 2. mintaterület kontroll (2.) parcelláján 2010.03.31. és 2013.04.18. között. Hibasávok a szórás értékeknek felelnek meg. 


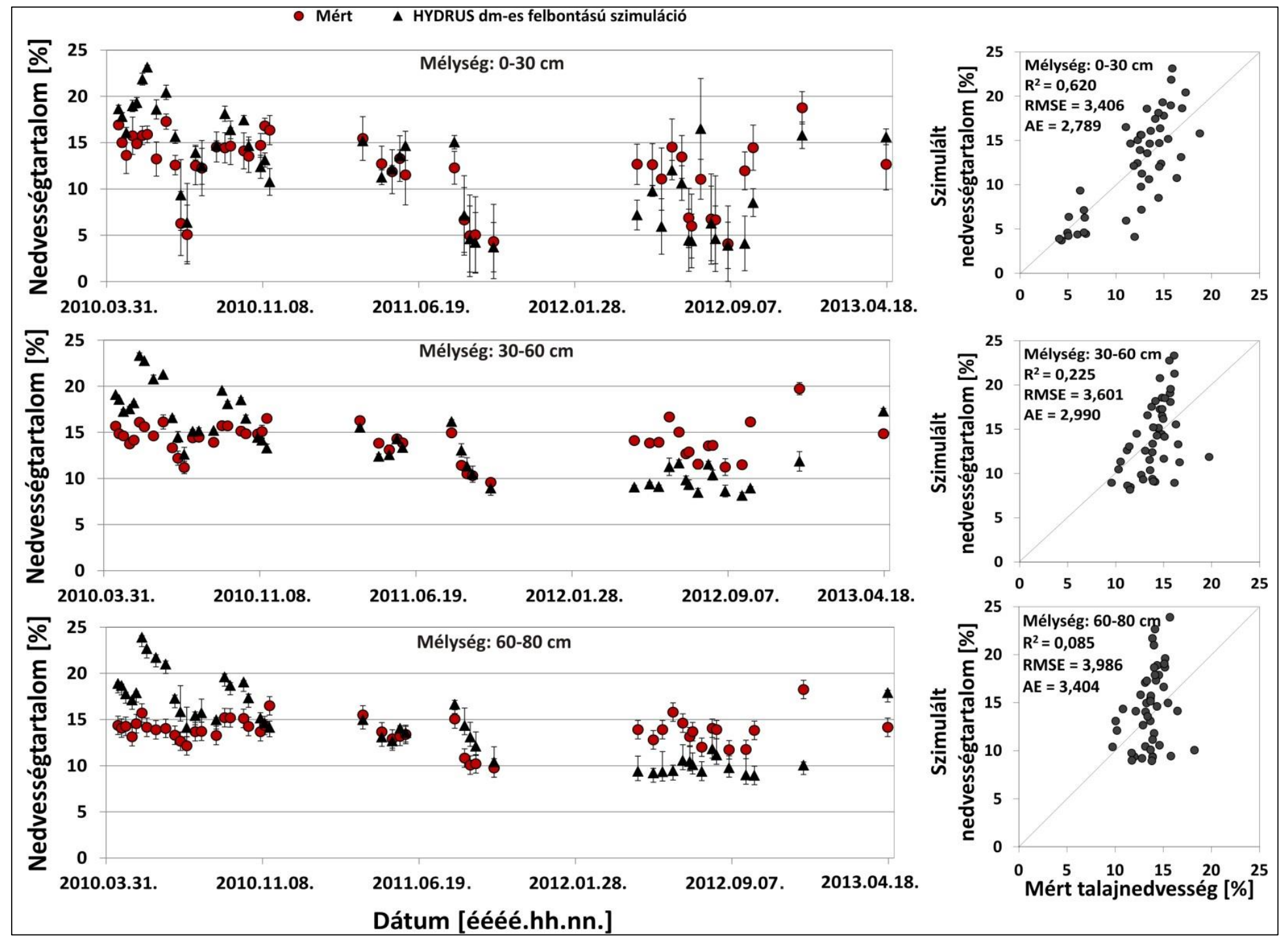

26. ábra: Különböző mélységben mért (piros kör) és deciméteres felbontású HYDRUS-1D modellel szimulált (fekete háromszög) talajnedvesség értékek változása és azok hibamutatói az őrbottyáni 2. mintaterület kontroll (2.) parcelláján 2010.03.31. és 2013.04.18. között. Hibasávok a szórás értékeknek felelnek meg. 
A hibamutatók (ld.: 7. táblázat) alapján a centiméteres felbontású HYDRUS-1D szimulált eredményei jobban közelítik a mért talajnedvesség értékeket, mint deciméteres felbontás esetén, de az eltérés mértéke nem szignifikáns. A HYDRUS-1D cm-es és dm-es felbontású modellezett eredményei a 0-10, 0-30 és 0-80 cm-es szintekben mutatják a legjobb egyezést, míg a mélyebb zónákban nagyobb különbség figyelhető meg, mely mértéke nem szignifikáns.

\begin{tabular}{|c|c|c|c|c|c|}
\cline { 2 - 6 } \multicolumn{1}{c|}{} & \multicolumn{5}{c|}{ Mélység } \\
\hline Hibamutatók & $\mathbf{0 - 1 0} \mathbf{~ c m}$ & $\mathbf{0 - 3 0} \mathbf{~ c m}$ & $\mathbf{3 0 - 6 0} \mathbf{~ c m}$ & $\mathbf{6 0 - 8 0} \mathbf{~ c m}$ & $\mathbf{0 - 8 0} \mathbf{~ c m}$ \\
\hline $\mathbf{r}$ & 0,989 & 0,989 & 0,974 & 0,978 & 0,987 \\
\hline $\mathbf{R}^{\mathbf{2}}$ & 0,979 & 0,977 & 0,949 & 0,956 & 0,974 \\
\hline RMSE & 1,059 & 0,878 & 1,137 & 1,037 & 0,765 \\
\hline AE & 0,719 & 0,588 & 0,817 & 0,721 & 0,484 \\
\hline
\end{tabular}

7. táblázat: A HYDRUS-1D cm-es és dm-es felbontású szimulált eredményeinek összehasonlítása.

A fentiek értelmében nincs szignifikáns különbség a HYDRUS-1D cm-es és dm-es felbontású szimulált talajnedvesség értékei között.

Egy terület talajnedvesség állapota függ a területre hulló csapadék beszivárgásának mértékétől is. A szakirodalom szerint a hosszabb száraz időszakok fokozzák a beszivárgás mértékét nedvesíthető talajok esetében, mivel megnövekszik szorpciós kapacitásuk (Orfánus et al., 2014). A 7.2.2-es fejezetben leírt vizsgálataink alapján az őrbottyáni talaj jól nedvesíthető.

Megfigyelhető, hogy a modellezett értékek alul-, illetve felülbecslik a mért talajnedvesség értékeket szárazabb, illetve csapadékosabb időszakok alatt. Ez az évjárathatás 2010-ben és 2012-ben jól megfigyelhető. A 8. táblázatból látható, ezen évek vegetációs periódusában hullott csapadékmennyiségek közötti különbségek. 2011-ben és 2012-ben is átlag alatti éves csapadékmennyiség esett, de az éven belüli eloszlás tekintetében 2012-ben kevesebb eső hullott a vegetációs időszakban.

\begin{tabular}{|c|c|c|c|}
\cline { 2 - 4 } \multicolumn{1}{c|}{} & $\begin{array}{c}\text { Éves mért csapadék } \\
\text { mennyiség [mm] }\end{array}$ & $\begin{array}{c}\text { Vetés és aratás között } \\
\text { lehullott csapadék } \\
\text { mennyiség [mm] }\end{array}$ & $\begin{array}{c}\text { Vegetációs időszakban lehullott } \\
\text { csapadék mennyisége az éves } \\
\text { csapadékhoz viszonyítva [\%] }\end{array}$ \\
\hline $\mathbf{2 0 1 0}$ & 1027,2 & 721,6 & 70 \\
\hline $\mathbf{2 0 1 1}$ & 408,2 & 280,4 & 69 \\
\hline $\mathbf{2 0 1 2}$ & 515,2 & 278,8 & 54 \\
\hline
\end{tabular}

8. táblázat: A csapadék mennyiségének évenkénti megoszlása a teljes év, illetve a vegetációs időszakok alatt.

(Őrbottyán, 2011 - 2012)

2010-es évben az éves átlagot jelentősen meghaladó mennyiségű csapadék esett az őrbottyáni mintaterületre és jól látható a 25. és 26. ábrákon, hogy a modell felülbecsli a talaj 
nedvességtartalmát, főképp a 30-60 és 60-80 cm-es zónákban. A 2012-es időszakban a modell azt szimulálja, hogy a kevesebb csapadék miatt jelentősen kisebb mértékü a beszivárgás, illetve a mélyebb rétegek (30-60 és 60-90 cm) nedvességtartalma. Azonban Orfánus és munkatársai (2014) kimutatták, hogy annak ellenére, hogy néhány talajfizikai tulajdonságot (pl.: talajnedvesség tartalmat, WDPT értéket, szorptivitását) szignifikánsan módosíthatnak hosszú periódusú időjárási állapotok (pl. aszály), a csapadék beszivárgása tekintetében egyensúlyi állapot figyelhető meg. Mivel a kezdeti állapotban változatlan maradhat a beszivárgás üteme mind csapadékos, mind pedig aszályos időszakok tekintetében. Azonban a modell figyelmen kívül hagyja ezt a jelenséget.

A mért és modellezett értékek hibamutatói alapján összevethetők a szimulált értékek a talajnedvesség mérés müszerhibájával. Az SzD értékek alapján $5 \%$-os valószínüségi szinten szignifikáns különbség mutatkozott a mért és modellezett értékek között 2010-ben és 2012ben. 2010-ben - extrém csapadékos tavasz és nyár esetében - a HYDRUS modell szignifikánsan felülbecsülte, míg 2012-ben — aszályos nyári és őszi időszak alatt — szignifikánsan alulbecsülte a talajnedvesség értékét minden mélységben. 2011-ben, mikor átlagos csapadékeloszlás volt, nem mutattunk ki szignifikáns különbséget a mért és modellezett talajnedvesség értékek között. A 0-30 cm-es szintekben jelentkező különbség oka lehet, hogy a modell nem követi megfelelően a növényi vízfelvételt. A HYDRUS-1D nem szimulálta megfelelően az extrém évjárathatásokat, melyek gyakorisága a jövőben növekedni fog.

\subsubsection{Beszivárgás és talajpárolgás modellezésének térbeli léptékfüggése}

A 27. ábrán a 4Mx modellel szimulált, $42 \mathrm{~mm}$-es zivatart követő kumulatív evaporáció látható. A modellezett 1 hónap alatt lényeges különbség mutatkozott aszerint, hogy a szimulációt megelözően a $30 \mathrm{~cm}$ vastag feltalaj legfelső $10 \mathrm{~cm}$-es zónáját $1+9 \mathrm{~cm}$ vagy 10 cm vastagságú felső talajrétegnek határoztuk meg. A szimuláció befejeződésével az $1 \mathrm{~cm}$-es talajréteg esetében 15,9 mm az összes párolgás mennyisége, míg $10 \mathrm{~cm}$-es feltalaj esetében ez 27,2 mm. Az $1 \mathrm{~cm}$ vastagságú felső réteg esetében az első nap legmagasabb az evaporáció mértéke, 2,94 mm/nap, másnapra $0,51 \mathrm{~mm} /$ nap értékre mérséklődik, ezt követően pedig naponta csökken a talajpárolgás. $10 \mathrm{~cm}$ vastagságú felszíni réteg esetében a modell 4 napon keresztül jelentős, $1 \mathrm{~mm} /$ napot meghaladó evaporációt számított, mely üteme lassú csökkenést mutatott. Ennek következtében, az evaporáció szimulálása során szignifikáns különbséget tapasztalhatunk annak függvényében, hogy milyen a modellünk felbontása. 


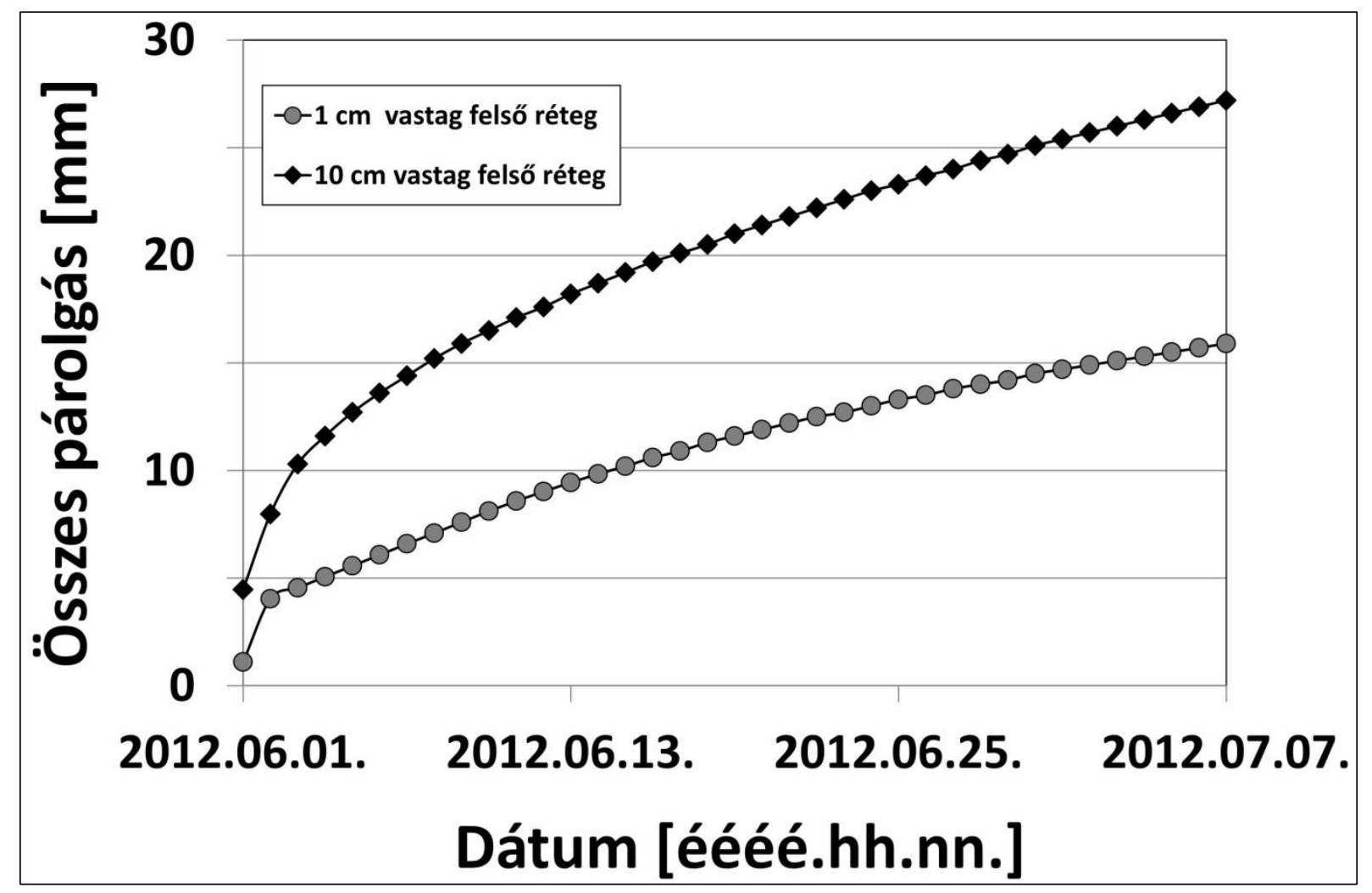

27. ábra: Homoktalaj szimulált, kumulatív párolgása 1 és $10 \mathrm{~cm}$ vastag feltalajban.

(Örbottyán, 2012.06.01. - 2012.07.07.)

A valóságban a kiszáradó vékony felszíni réteg jelentősen lelassítja a párolgás mértékét, így a $10 \mathrm{~cm}$-es felső réteg a modellben irreális eredményekhez vezethet. Ennek ellenére vannak olyan modellek, amelyek mégis ilyen durva felbontást használnak még a felszín közelében is.

A 40 mm-es zivatar szimulációt követően a nedvességtartalom változását is megvizsgáltuk 0-10 cm mélységü talajrétegekben (28. ábra). Elmondható, hogy mind az 1 $\mathrm{cm}$, mind pedig a $10 \mathrm{~cm}$ vastagságúnak meghatározott felső réteg, hasonló gyorsasággal és mértékben nedvesedett. Az idő múlásával a 0-10 cm mélységű réteg nedvességtartalomváltozása jelentős eltérést mutatott a felső talajréteg $1 \mathrm{~cm}$-nek, illetve $10 \mathrm{~cm}$-nek definiált vastagságának függvényében (28. ábra). Durvább modell felbontás esetén a $10 \mathrm{~cm}$ vastagságú felső réteg jobban kiszárad $\left(\Theta=0,05 \mathrm{~cm}^{3} / \mathrm{cm}^{3}\right)$. Finomabb talajszelvény felbontásban az $1 \mathrm{~cm}$ vastagságú felső réteg teljesen kiszárad $\left(\Theta=0 \mathrm{~cm}^{3} / \mathrm{cm}^{3}\right)$, de mivel az alatta lévő $9 \mathrm{~cm}$-es réteget nem hagyja gyorsan kiszáradni, ezért a 0-10 cm-es réteg gyorsabban szárad, ha $10 \mathrm{~cm}$ esnek vesszük a legfelső réteg vastagságát. Mivel az $1 \mathrm{~cm}$ vastagságú felső réteg kiszárad, és a hidraulikus vezetőképesség értéke számottevően lecsökken. $10 \mathrm{~cm}$-es felső réteg esetén a modell ennek a rétegnek a vízvezető képesség értékét egységesen, a felső $10 \mathrm{~cm}$ átlagos nedvesség tartalmához igazítja. Ebben az esetben addig megy az intenzív párolgás a 
modellszámítások alapján, amíg az egész $10 \mathrm{~cm}$-es réteg ki nem szárad, tehát több a vízveszteség.

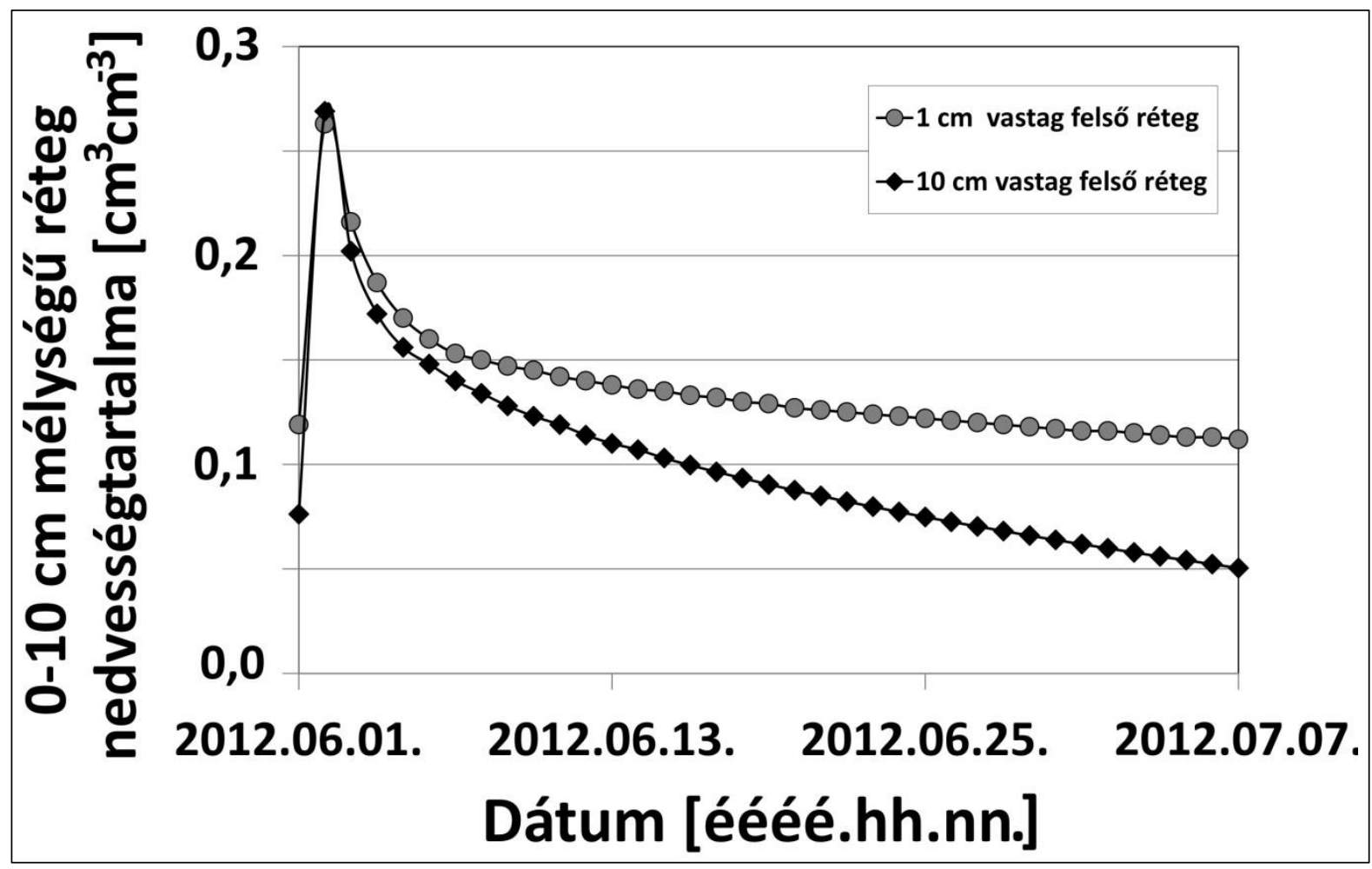

28. ábra: 0-10 cm mélységű talajrétegben szimulált nedvességtartalom változás 1 és $10 \mathrm{~cm}$ vastag feltalaj esetén.

(Örbottyán, 2012.06.01. - 2012.07.07.)

A zivatart követően szimulált talajpárolgás során az $1 \mathrm{~cm}$ vastagnak meghatározott felső réteg sokkal hamarabb kiszáradt és ennek következtében lelassította a párolgás mértékét, mint a 10 cm-nek definiált. Ezért az evaporáció szimulálása során szignifikáns különbséget tapasztalhatunk annak függvényében, hogy milyen szelvényfelbontást alkalmazunk a modellben.

A 0-10 cm mélységű rétegben szimulált nedvességtartalom változása jelentős eltérést mutatott az idő függvényében $1 \mathrm{~cm}$, illetve $10 \mathrm{~cm}$ vastagságú felső talajréteg-vastagságot használva. A fentiek értelmében, már csupán azáltal jelentős hibával terhelhetjük a modell szimulációnk eredményét, hogy milyen felbontású modellt használunk, azaz, hogy mekkora rétegekre osztjuk fel a talajszelvényt a program segítségével.

Az $1 \mathrm{~cm}$ vastagnak meghatározott felső réteg kiszárad, és a hidraulikus vezetőképesség értéke drasztikusan lecsökken, ezért kvázi nem továbbít hatékonyan vizet a légkör felé. Így leáll a felfelé áramlás és csökken összességében a párolgás. Ez a folyamat a valóságban sokszor menti meg a talajt és a növényeket a kiszáradástól, tehát aszályos időszakban fontos ennek a folyamatnak a leírása. 


\subsubsection{A térbeli heterogenitás következtében előálló modellezési problémák különböző szimulációs technikák esetén}

Az IC vagy CI módszerrel történő átlagolás jelentős eltérést okozhat a HYDRUS-1D-vel szimulált talajnedvesség értékek között (29. ábra). Az IC technika alkalmazása során az $5 \mathrm{~K}_{\mathrm{S}}$ mérés átlagolt hidraulikus vezetőképesség értékével végeztünk el egyetlen modell szimulációt, míg a CI módszer esetében az egyes mért telítési vízvezető képesség értékekkel futtattuk le a modellt, majd a kapott 5 beszivárgási eredményt átlagoltuk.

A feltalaj gyorsan átnedvesedett mind a 4 modellezett zivatarintenzitás $(0,0125,0,025$, 0,04 és $0,05 \mathrm{~mm} / \mathrm{sec}$ ) esetén, mely már 15 perccel a szimulált zivatar kezdetét követően jelentkezett (ld.: 29a. ábra). A felső $10 \mathrm{~cm}$-es talajszint nedvességtartalma megközelítette a modellezett talajszelvény maximális vízkapacitás $\left(\Theta_{\max }\right)$ értékét 0,04 és $0,05 \mathrm{~mm} / \mathrm{sec}$ intenzitású szimulált zivatarok esetén. 15 perccel a szimulált 0,0125 és $0,025 \mathrm{~mm} / \mathrm{sec}$ intenzitású zivatarok esetében minimális különbség volt az IC és CI módszerek között, azonban a 0,04 és $0,05 \mathrm{~mm} / \mathrm{sec}$ intenzitású modellezett csapadékesemények esetében különbség mutatkozott a két módszer között. Amennyiben először végeztük az átlagolást, kisebb értéket kaptunk a feltalaj nedvességtartalmára, míg a szelvény középső részére nagyobbat. A 29a. ábrából jól látható, hogy kevesebb víz jutott a talajba a zivatar végére, amikor a külön futtatásokat átlagoltuk (CI), mivel ekkor felszíni elfolyás is jelentkezett. Amikor a szimulációs eredményeket átlagoltuk $3 \mathrm{~mm}$ felszíni vízelfolyást tapasztatunk a modell eredményében, mivel előfordult alacsony $K_{S}$ érték $(30,1 \mathrm{~cm} / \mathrm{nap})$ is, amely miatt megjelent az elfolyás a szimulációk után végzett átlagolásban. Amennyiben először átlagoltunk, az átlag $\mathrm{K}_{\mathrm{S}}(89,9 \mathrm{~cm} / \mathrm{nap})$ már elég nagy volt, hogy ilyen csapadék intenzitás mellett a modell szerint már ne lépjen fel felszíni elfolyás. 


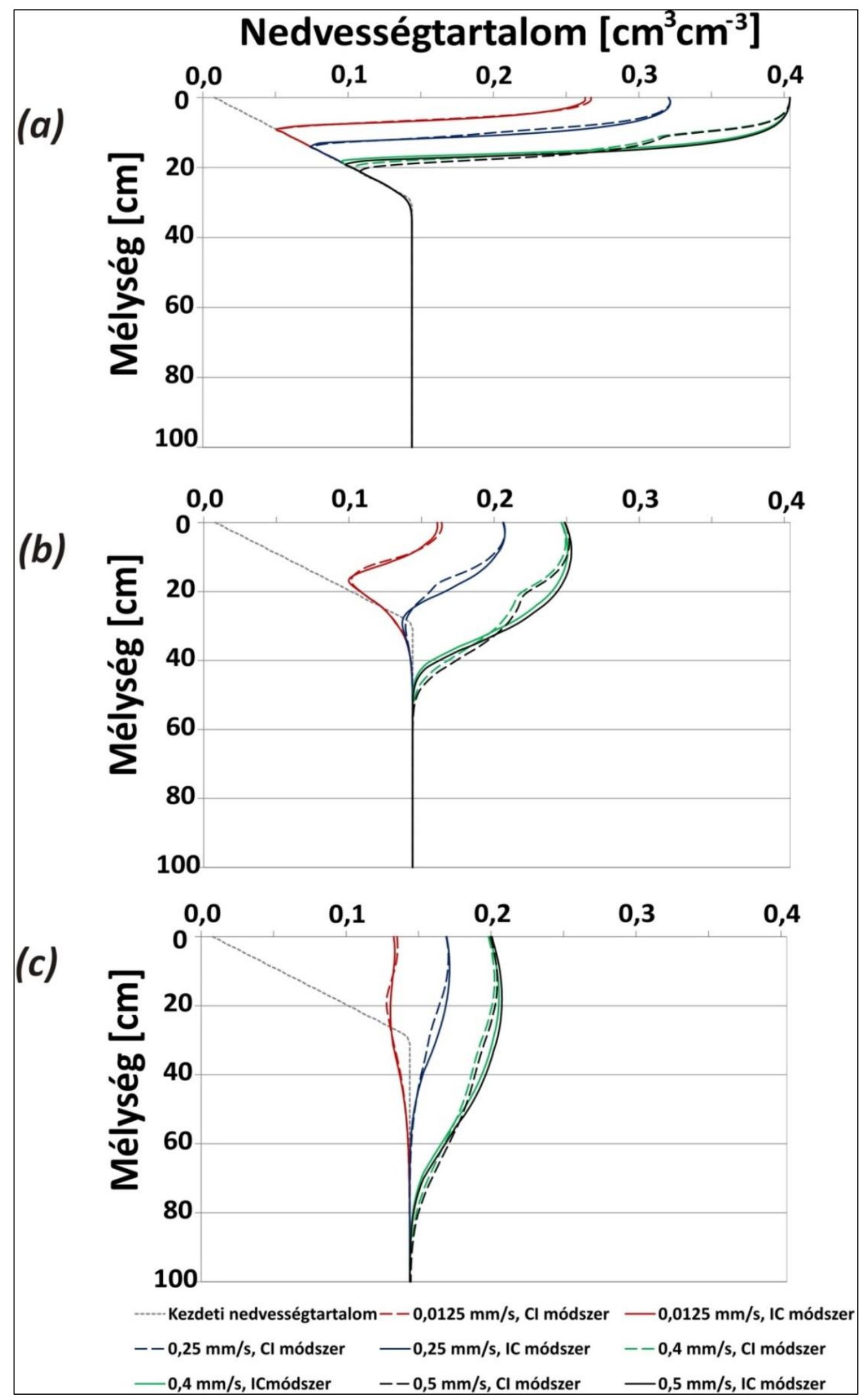

29. ábra: A talaj nedvességtartalma a mélység függvényében 30 perccel (a), 300 perccel (b) és 1440 perccel (c) a különböző intenzitású zivatarok kezdetét követően, Örbottyánban, 2011.09.08-án. Zivatar intenzitások: 0,0125 $\mathrm{mm} / \mathrm{sec}$ (piros vonal), 0,25 mm/sec (kék vonal), 0,4 mm/sec (zöld vonal), 0,5 mm/sec (fekete vonal). Kezdeti nedvességtartalom: szürke pontozott vonal. CI módszer (szaggatott vonal) az egyes mért $\mathrm{K}_{\mathrm{S}}$ értékekkel történt modell szimulációkkal kapott beszivárgási eredmények átlaga. IC módszer (sima vonal): az összes mért $\mathrm{K}_{\mathrm{S}}$ értékek átlagolt vízvezető képességével végzett szimuláció eredménye. 
A felszíni elfolyás értékek 30 perccel a szimulált zivatarintenzitásokat követően elérték a maximum értéküket (9. táblázat). Nem tapasztaltunk szignifikáns különbséget a két módszer felszíni elfolyás értékei között.

\begin{tabular}{|c|c|c|c|c|}
\cline { 2 - 5 } \multicolumn{1}{c|}{} & \multicolumn{4}{c|}{ Szimulált zivatarintenzitások } \\
\cline { 2 - 5 } \multicolumn{1}{c|}{} & $\begin{array}{c}0,0125 \\
{[\mathrm{~mm} / \mathrm{sec}]}\end{array}$ & $\begin{array}{c}0,025 \\
{[\mathrm{~mm} / \mathrm{sec}]}\end{array}$ & $\begin{array}{c}0,04 \\
{[\mathrm{~mm} / \mathrm{sec}]}\end{array}$ & $\begin{array}{c}0,05 \\
{[\mathrm{~mm} / \mathrm{sec}]}\end{array}$ \\
\hline $\begin{array}{c}\mathrm{K}_{\mathrm{S}}=30,1 \mathrm{~cm} / \text { nap esetében jelentkező } \\
\text { felszíni elfolyás [cm] }\end{array}$ & 0,00 & 0,57 & 3,95 & 5,71 \\
\hline $\begin{array}{c}\mathrm{K}_{\mathrm{S}}=94,9 \mathrm{~cm} / \text { nap esetében jelentkező } \\
\text { felszíni elfolyás [cm] }\end{array}$ & 0,00 & 0,00 & 1,78 & 3,38 \\
\hline $\begin{array}{c}\mathrm{K}_{\mathrm{S}}=97,9 \mathrm{~cm} / \text { nap esetében jelentkező } \\
\text { felszíni elfolyás [cm] }\end{array}$ & 0,00 & 0,00 & 1,71 & 3,30 \\
\hline $\begin{array}{c}\mathrm{K}_{\mathrm{S}}=112,8 \mathrm{~cm} / \text { nap esetében jelentkező } \\
\text { felszíni elfolyás [cm] }\end{array}$ & 0,00 & 0,00 & 1,38 & 2,91 \\
\hline $\begin{array}{c}\mathrm{K}_{\mathrm{S}}=113,3 \mathrm{~cm} / \text { nap esetében jelentkező } \\
\text { felszíni elfolyás [cm] }\end{array}$ & 0,00 & 0,00 & 1,37 & 2,90 \\
\hline $\begin{array}{c}\text { CI átlag esetében jelentkező felszíni } \\
\text { elfolyás [cm] }\end{array}$ & $\mathbf{0 , 0 0}$ & $\mathbf{0 , 1 1}$ & $\mathbf{2 , 0 4}$ & $\mathbf{3 , 6 4}$ \\
\hline $\begin{array}{c}\text { IC átlag: KS=89,9 cm/nap esetében } \\
\text { jelentkező felszíni elfolyás [cm] }\end{array}$ & $\mathbf{0 , 0 0}$ & $\mathbf{0 , 0 0}$ & $\mathbf{1 , 9 0}$ & $\mathbf{3 , 5 2}$ \\
\hline
\end{tabular}

9. táblázat: Felszíni elfolyás értékek különböző Ks értékek esetén a szimulált csapadékintenzitások függvényében, Örbottyánban.

5 órával a szimulált zivatarokat követően a nedvességtöbblet mélyebb rétegekben is jelentkezett (29b. ábra). A 0,04 és $0,05 \mathrm{~mm} / \mathrm{sec}$ intenzitású szimulált zivatarok esetében a feltalaj nedvességállapota lecsökkent a telített állapotról a szabadföldi vízkapacitást $\left(\Theta_{\mathrm{fc}}\right)$ értékére. Az IC és CI módszerek közötti különbségek tovább nőttek.

Egy nappal (29c. ábra) a szimulált zivatarokat követően a talajnedvesség lejutott a mélyebb rétegekbe. A HYDRUS-1D modellezett talajnedvesség eredményei alapján 0,0125 és $0,025 \mathrm{~mm} / \mathrm{sec}$ intenzitások esetén $60 \mathrm{~cm}$ mélységig hatol le a zivatar, míg 0,04 és 0,05 $\mathrm{mm} / \mathrm{sec}$ intenzitások esetében $90 \mathrm{~cm}$ mélységig érezteti hatását a csapadéktöbblet.

A fentiek értelmében az IC módszer elfedheti a bemenő adatokban megmutatkozó heterogenitást, ezért az CI módszer alkalmazása a javasolt, annak ellenére, hogy nagyobb számítási kapacitást és jelentősen több munkát igényel a felhasználótól. 


\section{4. ÚJ és ÚJSZERÜ TUDOMÁNYOS EREDMÉNYEK}

1. Homok és vályog fizikai féleségü talajokon kimutattuk, hogy a kumulatív csapadék függvényében talajmüvelést követően időben változnak a telítési vízvezető képesség és térfogattömeg értékek.

2. A mérések alapján megállapítható, hogy az őrbottyáni talaj jól nedvesíthető, míg a csólyospálosi talaj víztaszító, helyenként erősen víztaszító.

Kimutattuk, hogy a csólyospálosi talaj víztaszítását nem a huminsavak okozzák, hanem feltehetően a nagy mennyiségben előforduló még nem humifikálódott növényi maradványok.

A csólyospálosi víztaszító talajon elvégzett vizsgálataink alapján nem javasolt a Mini Disk Infiltrométer alkalmazása víztaszító talajok $\mathrm{K}_{\mathrm{S}}$ mérésére, de amennyiben mégis ezt a módszert alkalmazzuk, akkor a beszivárgás megindulását követően mért adatokat használjuk fel a kiértékeléshez.

Kimutattuk, hogy pedon léptéken belül a $\mathrm{K}_{\mathrm{S}}$ és víztaszítás térbeli változatossága jelentős, esetenként 3 nagyságrendnyi.

3. Agyag fizikai féleségü talajon sem találtuk reprezentatívnak a $100 \mathrm{~cm}^{3}$-es mintavételi egységet. A $\mathrm{K}_{\mathrm{S}}$ laboratóriumi meghatározására az $5650 \mathrm{~cm}^{3}$-es eljárás javasolható. Bebizonyítottuk, hogy a talaj telítési vízvezető képesség értékét szignifikánsan befolyásolja a választott mérési módszer, illetve a mintavételezési egység nagysága.

4. Vizsgálataink igazolták, hogy a 4Mx modell által számolt hőfoknap egy idealizált esetre vonatkozik, amiben nem jelennek meg az 5 perces felbontásban érzékelhető különbségek, ezáltal felül-, vagy alulbecsülhetjük a tényleges napi hőösszegeket. Ez jelentős modellezési hibát eredményezhet, mivel a termésszimulációs modellek a napi hőösszegek alapján számítják ki a növényi fejlődés ütemét.

5. Megállapítható, hogy a talajhőmérséklet dinamikáját a növény és hóborítottság szignifikánsan befolyásolja. Ezen jelenségek leírását a 4Mx modell talajhőmérséklet becslő moduljában továbbfejlesztettük.

6. A vizsgálataink alapján nem mutatható ki szignifikáns különbség a cm-es és dm-es felbontású HYDRUS-1D modellezett talajnedvesség értékei között. 
Átlagos csapadékmennyiség és -eloszlás esetén Örbottyánban nincs jelentős különbség a mért és szimulált talajnedvesség értékek között. Extrém aszályos, vagy csapadékos vegetációs időszakokban a szimulált és mért talajnedvesség értékek között szignifikáns különbséget tapasztaltunk. A HYDRUS-1D nem szimulálta megfelelően az extrém évjárathatásokat.

7. A beszivárgás és talajpárolgás szimulációja során jelentős különbségeket kaptunk annak függvényében, hogy $1 \mathrm{~cm}$ vagy $10 \mathrm{~cm}$ vastagságú felső rétegeket definiáltunk a modell számára.

8. Heterogén területre vonatkozóan kimutattuk, hogy a talajnedvesség modellezése esetén célszerű a modell több pontra megvalósított futtatását követően elvégezni az eredmények átlagolását. 


\section{KÖSZÖNETNYILVÁNÍTÁS}

Köszönetemet fejezem ki témavezetőmnek, Dr. Fodor Nándornak és belső konzulensemnek Prof. Dr. Sümegi Pálnak a munkámhoz nyújtott segítségükért és Prof. Dr. Rajkai Kálmánnak, Prof. Dr. Tóth Tibornak, akik munkámat figyelemmel kísérték és értékes tanácsokkal láttak el.

Köszönöm Dr. Filep Tibornak, Dr. Farkas Csillának és valamennyi kollégámnak a dolgozatom elkészüléséhez nyújtott segítségét, tanácsait. Köszönet illeti Bányász Ágnest és Mózes Zoltánnét, akik a laboratóriumi mérésekben nyújtottak segítséget, továbbá Aranyos Károlyt és Radimszky Lászlót, akik a terepi mérések kivitelezésébe kapcsolódtak be.

Köszönet illeti az MTA TAKI, az MTA ATK TAKI és az MTA ATK korábbi és jelenlegi vezetőit, Dr. Anton Attila, Prof. Dr. Lehoczky Éva igazgatókat, illetve Prof. Dr. Bedő Zoltán főigazgatót, amiért kutatásaimat támogatták.

Köszönetet mondok továbbá külföldi kollégáimnak, akikkel az elmúlt években együtt dolgoztam és sokat tanulhattam:

Prof. Dr. Lubomír Lichner, Institute of Hydrology, Slovak Academy of Sciences, Bratislava, Slovakia.

Dr. Tomas Orfánus, Institute of Hydrology, Slovak Academy of Sciences, Bratislava, Slovakia.

Hálás köszönettel tartozom Szüleimnek, akik mindenben támogattak és a csólyospálosi mintaterületet rendelkezésemre bocsátották.

A doktori értekezés és a hozzá kapcsolódó kutatások a TÁMOP 4.2.4.A/2-11-1-2012-0001 azonosító számú Nemzeti Kiválóság Program - Hazai hallgatói, illetve kutatói személyi támogatást biztosító rendszer kidolgozása és müködtetése országos program címü kiemelt projekt keretében zajlott. A projekt az Európai Unió támogatásával, az Európai Szociális Alap társfinanszírozásával valósul meg. 


\section{IRODALOMJEGYZÉK}

1. Addiscott, T.M. és Wagenet, R.J. 1985a. A simple method for combining soil properties that show variability. Soil Sci. Soc. Am. J. 49: 1365-1369.

2. Addiscott, T.M. and Wagenet, R.J. 1985b. Concepts of solute leaching in soils: a review of modelling approaches. Journal of Soil Science. 36: 411-424. doi: 10.1111/j.13652389.1985.tb00347.x

3. Addiscott, T.M. 1993. Simulation modeling and soil behavior. Geoderma. 60: 15-40.

4. Arnold, R.W., Szabolcs, I., Targulian, V.O. 1990. Global Soil Change. IIASA. Laxenburg. Austria.

5. Aronovici, V.S. 1955. Model study of ring infiltrometer performance under low initial soil moisture. Soil Sci. Soc. Amer. Proc. 19: 1-6.

6. Baker, R.S. és Hillel, D. 1990. Laboratory tests of a theory of fingering during infiltration into layered soils. Soil Sci. Soc. Am. J. 54:20-30.

7. Bechini, L., Ducco, G., Donatelli, M., Stein, A. 2000. Modelling, interpolation and stochastic simulation in space and time of global solar radiation. Agriculture, Ecosystems and Enviroment. 81: 29-42.

8. Bisdom, E.B.A., Dekker, L.W., Schoute, J.F.T. 1993. Water repellency of sieve fractions from sandy soils and relationships with organic material and soil structure. Geoderma. 56: 105-118.

9. Boogaard, H.L., van Diepen, C.A., Roetter, R.P., Cabrera, J.M.C.A., Laar, H.H.v. 1998. User's Guide for the WOFOST 7.1 Crop Growth Simulation Model and WOFOST Control Center 1.5. DLO-Winand Staring Centre/Wageningen.

10. Booltink, H.W.G., Bouma, J., Giménez, D. 1991. Suction crutst infiltrometer for measuring hydraulic conductivity of unsaturated soil near saturation. Soil Sci. Soc. Am. J. 55: 566-568.

11. Boone, R.D., Nadelhoffer, K.J., Canary, J.D., Kaye, J.P. 1998. Roots exert a strong influence on the temperature sensitivity of soil respiration. Nature. 396: 570-572.

12. Bouma, J., Hillel D.I., Hole, F.D., Amerman, C.R. 1971. Field measurements of unsaturated hydraulic conductivity by infiltration through artificial crusts. Soil Sci. Soc. Am. J. 35: 362-364.

13. Bouma,J. 1989. Using soil survey data for quantitative land evaluation. Advances in Soil Science. 9: 177-213.

14. Brisson, N., Mary, B., Ripoche, D., Jeuffroy, M.H., Ruget, F., Nicoullaud, B., Gate, P., Devienne-Barret, F., Antonioletti, R., Durr, C., Richard, G., Beaudoin, N., Recous, S., 
Tayot, X., Plenet, D., Cellier, P., Machet, J.M., Meynard, J.M., Delécolle R. 1998. STICS: a genetic model for the simulation of crop and their water and nitrogen balances. I. Theory and parameterization applied to wheat and maize. Agronomie. 18: 311-346.

15. Buzás, I. 1988. Talaj- és agrokémiai vizsgálati módszerkönyv 2. A talajok fizikaikémiai és kémiai vizsgálati módszerei. Mezőgazdasági Kiadó. Budapest. p. 242.

16. Buzás, I. 1993. Talaj-és agrokémiai vizsgálati módszerkönyv 1. A talaj fizikai, vízgazdálkodási és ásványtani vizsgálata. INDA 4231 Kiadó, Budapest. p. 357.

17. Campbell, G.S. 1985. Soil Physics with BASIC. Transport Models for Soil-Plant Systems. 53-54. Elsevier. Amsterdam.

18. Cannon, J.R. 1984. The One-Dimensional Heat Equation, Encyclopedia of Mathematics and Its Applications 23 (1st ed.), Reading-Menlo Park-London-Don Mills-SidneyTokyo/ Cambridge-New York-New Rochelle-Melbourne-Sidney: Addison-Wesley Publishing Company/Cambridge University Press, pp. XXV+483, ISBN 978-0-52130243-2, MR.

19. Carsel, R.F. és Parrish, R.S. 1988. Developing joint probability distributions of soil water retention characteristics. Water Resour. Res. 24: 755-769.

20. Clothier, B.E. és White, I. 1981. Measurement of sorptivity and soil water diffusivity in the field. Soil Sci. Soc. Am. J. 45: 241-245.

21. Cornelis, P.K. 1995. The water budget of heterogeneous areas. Ph.D. thesis, Wageningen Agricultural University, The Netharlands.

22. Csathó, P., Árendás, T., Fodor, N., Németh, T. 2007. A legelterjedtebb hazai trágyázási szaktanácsadási rendszerek tesztelése szabadföldi kísérletekben. Agrokémia és Talajtan. 56: $173-190$

23. Csathó, P., Árendás, T., Fodor, N., Németh, T. 2009. Evaluation of different fertilizer recommendation systems on various soils and crops in Hungary. Communications in Soil Science and Plant Analysis. 40 (11-12): 1689-1711.

24. Cheviron, B. és Coquet, Y. 2009. Sensitivity Analysis of Transient - MIM HYDRUS1D: Case study related to pesticide fate in soils. Vadose Zone Journal, 8: 1064-1079.

25. Chung, S.O. és Horton, R. 1987. Soil heat and water flow with a partial surface mulch. Water Resources Research. 23: 2175-2186.

26. Dalton, F.N. és van Genuchten, M. 1986. The time-domain reflectometry method measuring soil water content and salinity. Geoderma. 38: 237-250.

27. Darcy, H. 1856. Les fontaines publiques de la ville de Dijon. Paris: Dalmont. 
28. DeBano, L.F. 1969. Water repellent soils: a worldwide concern in management of soil and vegetation. Agric. Sci. Rev. 7: 11-18.

29. Decagon. 2010. Mini Disk Infiltrometer User's Manual. Version 6. www.decagon.com/pdfs/manuals/Infiltrometer_v6.pdf 2010 Accessed:01/06/2010.

30. Dekker, L.W. és Ritsema, C.J. 1994. How water moves in a water repellent sandy soil. 1. Potential and actual water repellency. Water Resour. Res. 30: 2507-2517.

31. Dekker, L.W. és Ritsema, C.J. 1996. Variation in water content and wetting patterns in Dutch water repellent peaty clay and clayey peat soils. Catena. 28: 89-105.

32. Dekker, L.W., Oostindie, K., Ziogas, A.K., Ritsema, C.J. 2001. The impact of water repellency on soil moisture variability and preferential flow. International Turfgrass Society Research Journal. 9: 498-505.

33. Dekker, L.W., Oostindie, K., Ritsema, C.J. 2005. Exponential increases of publications related to soil water repellency. Aust. J. Soil Res. 43: 403-441.

34. Doerr, S.H. 1998. On standardizing the "Water Drop Tenetration Time" and the "Molarity of an Ethanol Droplet" techniques to classigy soil hydrophobicity: a case study using medium textured soils. Earth Surf. Process. Landf. 23: 663-668.

35. Doerr, S.H. és Thomas, A.D. 2000. The role of soil moisture in controlling water repellency: new evidence from forest soils in Portugal. J. Hydrol. 231-232: 134-147.

36. Doerr, S.H., Shakesby, R.A., Walsh, R.P.D. 2000. Soil water repellency: its causes, characteristics and hydro-geomorphological significance. Earth-Science Reviews. 51: $33-65$.

37. Dong, S., Scagel, C.F., Cheng, L., Fuchigami, L.H., Rygiewicz, P.T. 2001. Soil temperature and plant growth stage influence nitrogen uptake and amino acid concentration of apple during early spring growth. Tree Physilogy. 21 (8): 541-547.

38. Dövényi, Z. 2010. Magyarország kistájainak katasztere. MTA Földrajztudományi Kutatóintézet. Budapest. p. 876.

39. Ellies, A., Ramírez, C., Mac Donald, R. 2005. Organic matter and wetting capacity distribution in aggregates of Chilean soils. Catena. 59: 69-78.

40. Famiglietti, J.S., Rudnicki, J.W., Rodell, M. 1998. Variability in surface moisture content along a hillslope transect: Rattlesnake Hill, Texas. Journal of Hydrology. 210: 259-281.

41. Farkas, Cs. 2001. A talajnedvesség-forgalom modellezése a talajfizikai tulajdonságok területi változatosságának és szezonális dinamikájának tükrében. Ph.D. értekezés. ELTE TTK Doktori Iskola. 
42. Farkas, Cs., Randriamampianina, R., Majercak, J. 2005. Modelling impacts of different climate change scenarios on soil water regime of a Mollisol. Cereal Research Communications 33: 185-188.

43. Faybishenko, B., Bodvarsson, G.S., Hinds, J., Witherspoon, P.A. 2003. Scaling and hierarchy of models for flow processes in unsaturated fractured rock. In: Pachepsky, Y., Radcliffe D.E., Selim M.H. 2003. Scaling methods in soil physics. CRC Press. Pp. 373417.

44. Fodor, N., Kovács, G. J., Karuczka, A. 2001. A CERES modell továbbfejlesztése I. A Richards-egyenlet beépítése után, összehasonlítás az eredeti változattal. Agrokémia és Talajtan, 50 (1-2): 35-46.

45. Fodor, N., Kovács, G.J. 2001. A CERES modell továbbfejlesztése II. A Richardsegyenlet paramétereinek meghatározása mérések, ill. pedotranszfer függvények segítségével. Agrokémia és Talajtan, 50 (1-2): 47-61.

46. Fodor, N. 2002: A nedvességforgalom modellezése növénytermesztési modellekben. Ph.D. értekezés. Debreceni Egyetem ATC.

47. Fodor, N., Máthéné-Gáspár, G., Pokovai, K., Kovács, G.J. 2003. 4M-software package or modelling cropping systems. European Journal of Agronomy. 18: 389-393.

48. Fodor, N. és Rajkai, K. 2004. Talajfizikai tulajdonságok becslése és alkalmazásuk modellekben. Agrokémia és Talajtan, 53:225-238.

49. Fodor, N. és Rajkai, K. 2005. Számítógépes program a talajok fizikai és vízgazdálkodási jellemzőinek egyéb talajjellemzőkből történő számítására (TALAJTANonc1.0). Agrokémia és Talajtan. 54: 25-40.

50. Fodor, N., Blaskó, L., Éri, L., Rajkai, K. 2009. Hidraulikus vezetőképesség mérési és becslési eredmények összehasonlítása homoktalajra. Agrokémia és Talajtan. 58: 369380.

51. Fodor, N., Sándor, R., Orfánus, T., Lichner, L., Rajkai, K. 2011. Evaluation method dependency of measured saturated hydraulic conductivity. Geoderma. 165: 60-68.

52. Fodor, N. és Mika, J. 2011. Using analogies from soil science for estimating solar radiation. Agricultural and Forest Meteorology. 151: 78-86.

53. Fodor, N. 2012. 4Mx légkör-talaj-növény modell: alkalmazások, lehetőségek és kihívások. Agrárinformatika. 3: 50-60.

54. Forrester, J.W. 1968. Principles of systems. Cambridge, Mass., U.S.A.: Wright-Allen Press. 
55. Food and Agriculture Organization of the United Nations, Expert consultation on revision of FAO methodologies for crop water requirements, ANNEX $V$, FAO PenmanMonteith Formula, Rome Italy, 1990.

56. Gardner, W.R. 1958. Some steady state solutions of unsaturated moisture flow equations with application to evaporation from a water table. Soil Sci. 85: 228-232.

57. Goodrich, L.E. 1982. The influence of snow cover ont he ground thermal regime. Canadian Geotechnical Journal. 19: 421 - 432.

58. Gregory, J.H., Dukes, M.D., Miller, G.L., Jones, P.H. 2005. Analysis of double-ring infiltration techniques and development of a simple automatic water delivery system. Applied Turfgrass Science. doi:10.1094/ATS-2005-0531-01-MG.

59. Gupta, S.C. és Larson, W.E. 1979. Estimating soil water retention characteristics from particle-size distribution, organic matter, and bulk density. Water Resour. Res. 15: 1633-1635.

60. Gutmann, E.D. és Small, E.E. 2005. The effect of soil hydraulic properties vs. soil texture in land surface models. Geophys. Res. Lett. 32: p. $\mathrm{L02402}$ http://dx.doi.org/10.1029/2004GL021843

61. Hagyó, A. 2009. Vízforgalom gyep és erdő területeken. Ph.D. értekezés. Szent István Egyetem.

62. Hallett, P.D., Baumgartl, T., Young, I.M. 2001. Subcritical water repellency of aggregates from a range of soil management practices. Soil Sci. Soc. Am. J. 65: 184-190.

63. Hallett, P.D. 2007. An introduction to soil water repellency. In: Adjuvants for Agrochemicals, Gaskin, R.E. (ed). Hand Mulimedia: Christchurch, New Zealand; 13 pp.

64. Hargreaves, G.H., 1994. Defining and using reference evapotranspiration. J. Irrig. Drain. Eng., 120(6), 1132-1139.

65. Harnos, Zs. 1985. Az agroökológiai adottságok rendszerének matematikai modellezése. Doktori értekezés, Budapest.

66. Hartmann, P., Zink, A., Fleige, H., Horn, R. 2012. Effect of compaction, tillage and climate change on soil water balance of Arable Luvisols in Northwest Germany. Soil and Tillage Research, 124: 211-218.

67. Hasfurther, V.R. és Burman, R.D. 1974. Soil temperature modeling using air temperature as a driving mechanism. Transactions of the American Society of Agricultural Engineers. 17: 78-81.

68. Haverkamp, R., Leij, F.J., Fuentes, C., Sciortino A., Ross, J. 2005. Soil water retention: I. Introduction of a Shape Index. Soil Sci. Am. J. 69: 1881-1890. 
69. Hayes, M.H.B. és Clapp, C.E. 2001. Humic substances: considerations of compositions, aspects of structure, and environmental influences. Soil Science. 166: 723-737.

70. Holmgren, G.G.S. 1988. The Point Representation of Soil. Division S-5-Soil Genesis, morphology and classification. Soil Sci. Soc. Am. J. 52:712-716.

71. Hoosbeek, M.R. és Bryant, R.B. 1992. Towards the quantitative modeling of pedogenesis - A review. Geoderma 55. 183-210.

72. Hunter, A.E., Chau, H.W., Si, B.C. 2011. Impact of tension infiltrometer disc size on measured soil water repellency index. Can. J. Soil Sci. 91: 77-81.

73. Huzsvai L., Rajkai K. és Szász G. 2005. Az agroökológiai modellezés technikája. Kempelen Farkas Digitális Tankönyvtár egyetemi tankönyve a http://www.hik.hu/tankonyvtar/site/books/b114/index.html Internet címen.

74. Huzsvai, L. 2006. A kukorica potenciális termésének modellezése. In: Környezetkímélő növénytermesztés - minőségi termelés. 80-92. Nagy, J. és Dobos, A. eds. Debrecen. Debreceni Egyetem ATC.

75. Jabro, J.D. 1992. Estimation of saturated hydraulic conduvtivity of soils from particle size distribution and bulk density data. Trans. ASAE. 35:557-560.

76. Jarvis, N.J. 1994. The MACRO model (Version 3.1), Technical description and sample simulations. Reports and Dissertations 19. Dept. Soil Sci., Swedish Univ. Agric. Sci., Uppsala, Sweden, pp. 51.

77. Jarvis, N.J., Zavattaro, L., Rajkai, K., Reynolds, W.D., Olsen, P.-A., McGechan, M., Mecke, M., Mohanty, B., Leeds-Harrison, P.B., Jacques, D. 2002. Indirect estimation of near-saturated hydraulic conductivity from readily available soil information. Geoderma. 108: 1-17.

78. Jensen, D.T., Hargreaves, G.H., Temesgen, B., Allen, R.G. 1997. Computation of Eto under nonideal conditions, J. Irrig. Drainage, 123: 394-400.

79. Johnson, W.M. 1963. The pedon and the polypedon. Soil Sci. Soc. Am. J. 27: 212-215.

80. Jones, J.W., Hoogenboom, G., Porter, C.H., Boote, K.J., Batchelor, W.D., Hunt, L.A., Wilkens, P.W., Singh, U., Gijsman, A.J., Ritchie, J.T. 2003. DSSAT Cropping System Model. European Journal of Agronomy. 18: 235-265.

81. Kádár, I., Márton, L., Láng, I. 2012. Az örbottyáni 50 éves örök rozs és egyéb mütrágyázási tartamkísérletek tanulságai. Magyar Tudományos Akadémia ATK Talajtani és Agrokémiai Intézet. Budapest, 2012. pp. 172.

82. Katul G.G. és Parlange, M.B. 1992. Estimation of bare soil evaporation using skin temperature measurements. Journal of Hydrology. 132: 91-106. 
83. Kawamoto, K., Mashino, S., Oda, M., Miyazaki, T. 2004. Moisture structures of laterally expanding fingering flows is sandy soils. Geoderma. 119:197-217.

84. Kim, Y., Wang, G. 2005. Modeling seasonal vegetation variation and its validation against Moderate Resolution Imaging Spectroradiometer (MODIS) observations over North America. J. Geophys. Res. 110, D04106 doi:10.1029/2004JD005436.

85. Kirkham, D. és Powers, W.L. 1972. Advanced soil physics. John Wiley \& Sons, New York.

86. Klute, A. 1952. A numerical method for solving the flow equation for water in unsaturated materials. Soil Science 73: 105-116.

87. Knapp, A.K., Beier, C., Briske, D.D., Classen, A.T., Luo, Y., Reichstein, M., Smith, M.D., Smith, S.D., Bell, J.E., Fay, P.A., Heisler, J.L., Leavitt, S.W., Sherry, R., Smith, B., Weng, E. 2008. Consequences of more extreme precipitation regimes for terrestrial ecosystems. Bioscience 58:811-821.

88. Kovács, B. és Saznyi, J. 2005. Hidrodinamikai és transzportmodellezés II. Miskolci Egyetem - Szegedi Tudományegyetem - GÁMA-GEO, p. 213.

89. Kovács, G.J. 1995. A CERES modell felhasználása szakterületünkön. Agrokémia és Talajtan. 44: 249-262.

90. Kutílek, M. és Nielsen D.R. 1994. Soil Hydrology. Catena Verlag. Cremlingen-Destedt, Germany. p. 370.

91. Kutílek, M. 2004. Soil hydraulic properties as related to soil structure. Soil and Tillage Research. 79: 175-184.

92. Lai, J. és Ren, L. 2007. Assessing the size dependency of measured hydraulic conductivity using Double-Ring Infiltrometers and numerical simulations. Soil Sci. Soc. Am. J. 71:1667-1675.

93. Lampurlanés, J. és Cantero-Martínez, C. 2003. Soil bulk density and penetration resistance under different tillage and crop management systems and their relationship with barley root growth. Agron. J. 95: 526-536.

94. Leij, F.J., Alves, W.J., Van Genuchten, M.T., Williams, J.R. 1996. The UNSODA Unsaturated Soil Hydraulic Database: user's manual version 1.0. National Risk Management Laboratory, Cincinnati. OH. Technical Report / Environmental Protection Agency on. EPA/600/R-96/095. p. 103.

95. Lichner, L., Dlapa, P., Doerr, S.H., Mataix-Solera, J. 2006. Evaluation of different clay minerals as additives for soil water repellency alleviation. Applied Clay Sci. 31: 238248. 
96. Lichner, L., Holko, L., Zhokova, N., Schacht, K., Rajkai, K., Fodor, N., Sándor, R. 2012. Plants and biological soil crust influence the hydrophysical parameters and water flow in an aeolian sandy soil. J. Hydrol. Hydromech. 60: 309-318.

97. Lichner, L., Dusek, J., Dekker, L.W., Zhukova, N., Fasko, P., Holko, L. 2013. Comparison of two methods to assess heterogeneity of water flow in soils. Journal of Hydrology and Hydromechanics.61(4): 299-304.

98. Lilly, A. 1997. A description of the HYPRES database (Hydraulic Properties of European Soils). In: Bruand, A., Duval, O., Wösten, J.H.M. eds. The use of pedotransfer in soil hydrology research in Europe: proceedings of the second workshop of the project „Using existing soil data to derive hydraulic parameters for simulation modelling in environmental sutdies and in land use planning”. INRA Orleans, France, 10-12 October 1996. INRA, Orleans. European Commission no. EUR 17307 EN.

99. Liu, X. és Huang, B. 2005. Root physiological factors involved in cool-season grass response to high soil temperature. Environmental and Experimental Botany. 53 (3): 233-245.

100. Meadow, D.L. 1972. The limits to growth. Nex York, U.S.A. Universe Books.

101. Messing, I. és Jarvis, N.J. 1993. Temporal variation in the hydraulic conducticity of a tilled clay soil as measured by tension infiltrometers. J. Soil Sci. 44: 11-24.

102. Molnár, B. 1991. Modern Lacustrine Calcite, Dolomite and Magnesite Formation in Hungary. Turun Yliopisto. 70: 1-22.

103. Monteith, J.L. 1981. Evaporation and surface temperature, Quarterly J. Royal Meteo. Soc., 107: 1-27.

104. Monteith, J.L. és Unsworth, M.H. 1990. Principles of Environmental Physics, Edward Arnold, London.

105. Montgomery, E.G. 1911. Correlation studies in corn. 24 th Annual Report. Agricultural Experiment Station of Nebraska. pp. 108-159.

106. Moradi, A.B., Carminati, A., Lamparter, A., Woche, S.K., Bachmann, J., Vetterlein, D., Vogel, H.J., Osval, S.E. 2012. Is the Rhizosphere Temporarily Water Repellent? Vadose Zone Journal. 11: - .doi:10.2136/vzj2011.01.20

107. Móricz, N. 2011. Egy erdő és parlagterület vízforgalmának összehasonlító vizsgálata. Ph.D. értekezés. Nyugat-Magyarországi Egyetem. p.100.

108. Mualem, Y. 1976. A new model for predicting the hydraulic conductivity of unsaturated porous media. Water Resour. Res. 12: 513-522.

109. Nabi, G. és Mullins, C.E. 2008. Soil temperature dependent growth of cotton seedlings before emergence. Pedosphere. 18: 54-59. 
110. Nemes, A., Rawls, W.J., Pachepsky, Y.A. 2005. Influence of Organic Metter ont he Estimation of Saturated Hydraulic Conductivity. Soil Sci. Soc. Am. J. 69: 1330-1337.

111. Németh, T. és Buzás, I. 1991. Nitrogéntrágyázási tartamkísérlet humuszos homok- és mészlepedékes csernozjom talajon. Agrokémia és Talajtan. 40: 399-408.

112. Németh, T. 1995. Nitrogen in Hungarian soils - nitrogen management relation to groundwater protection. J. Contaminant Hidrology. 20: 185-208.

113. Novák, T.J. 2013. Talajtani praktikum. Talajok terepi vizsgálata, leírása és osztályozása. Debrecen. p. 188.

114. Olness, A., Lopez, D., Archer, D. 2001. Factors affecting microbial formation of nitratenitrogen in soil and their effects on fertilizer nitrogen use efficiency. TheScientificWorldJournal. 1: 122-129.

115. Orfánus, T., Dlapa, P., Fodor, N., Rajkai, K., Sándor, R., Nováková, K. 2014. How severe and subcritical water repellency determines the seasonal infiltration in natural and cultivated sandy soils. Soil \& Tillage Research 135: 49-59.

116. Paraíba, L.C., Cerdeira, A.L., Da Silva, E.F., Martins, J.S., Da Costa Coutinho, H.L. 2003. Evaluation of soil temperature effect on herbicide leaching potential into groundwater in the Brazilian Cerrado. Chemosphere. 53: 1087- 1095.

117. Piccolo, A. és Mirabella, A. 1987. Molecular weight distribution of peat humic substanoes extracted with different inorganic and organic solutions. The Science of the Total Environment. 62: 39-46.

118. Pietikäinen, J., Pettersson, M., Bååth, E. 2005. Comparison of temperature effects on soil respiration and bacterial and fungal growth rates. FEMS Microbiology Ecology. 52:49-58.

119. Priestley, C.H.B. és Taylor, R.J. 1972. Ont he assessment of surface heat flux and evaporation using large-scale parameters. Monthly Water Rev. 100: 81-92.

120. Rahi, G.S. és Jensen, R.D. 1975. Effect of temperature on soilwater diffusivity. Geoderma, 14: 115-124.

121. Rajkai, K. 1984. A talaj kapilláris vízvezetőképességének számítása a pF-görbe alapján. Agrokémia és Talajtan. 33: 50-62.

122. Rajkai, K. 1987. A talaj víztartartóképessége és különbözö talajtulajdonságok összefüggéseinek vizsgálata. Agrokémia és Talajtan. 36: 15-28.

123. Rajkai, K. 1991. A talajfelszín nedvességtartalmának mérése TDR - módszerrel. Hidrológiai Közlöny. 71: 37-43.

124. Rajkai, K. 2001. Szemle: Modellezés és modellhasználat a talajtani kutatásban. Agrokémia és Talajtan, 50:469-508. 
125. Rajkai, K. 2004. A víz mennyisége, eloszlása és áramlása a talajban. MTA Talajtani és Agrokémiai Kutatóintézet, Budapest.

126. Rajkai, K., Kabos, S., van Genuchten, M.Th. 2004. Estimation the water retention curve from soil properties: comparison of linear, nonlinear and concomitant variable methods. Soil \& Tillage Research. 79: 145-152.

127. Ramos, T.B., Šimůnek, J., Goncalves, M.C., Martins, J.C., Prazeres, A., Castanheira, N.L., Pereira, L.S. 2011. Field evaluation of a multicomponent soulte transport model in soils irrigated with saline waters. Journal of Hydrology. 407: 129-144.

128. Rao, P.S.C., Rao, P.V., Davidson J.M. 1977. Estimation of the spatial variability of the soil-water-flux. Soil.Sci.Soc.Am.Proc. 41:1208-1209.

129. Reynolds, W.D. és Elrick, D.E. 1986. A method for simultaneous in situ measurement in the vadose zone of field-saturated hydraulic conductivity, sorptivity and the condctivity-pressure head relationship. Grounkd Water Monitoring \& Remediation. 6: 84-95.

130. Richards, L.A. 1931. Capillary conduction of liquids through porous mediums. Physics. 1: 318-333.

131. Richter, J. 1987. The Soil as a Reactor. Catena Verlag. Cremlingen. Germany.

132. Ritchie, J.T. 1985. A user-oriented model of the soil water balance in wheat. In: Wheat Growth and Modeling. Day, W. and Atkin, R.K. eds. New York, USA. Plenum Publishing Crop.

133. Ritchie, J.T. 1991. Wheat phasic development. In: Hanks és Ritchie (ed.) Modeling plant and soil systems. Agron. Monogr. 31, ASA, CSSSA, SSSA, Madison, WI. p. 3154.

134. Ritsema, C.J. és Dekker, L.W. 2003. Soil water repellency: occurrence, consequences and Amelioration. Elsevier Science. p. 358.

135. Rodríguez-Alleres, M. és Benito, E. 2011. Spatial and temporal variability of surface water repellency in sandy loam soils of NE Spain under Pinus pinaster and Eucalyptus globulus plantations. Hydrological Processes. 25: 3649-3658.

136. Romano, N. és Palladino, M. 2002. Prediction of soil water retention using soil physical data and terrain attributes. Journal of Hydrology. 265: 56-75.

137. Rose, C.W., Stern, W.R., Drummond, J.E. 1965. Determination of hydraulic conductivity as a function of depth and water content for soil in situ. Water Resour. Res. 27: 569-575.

138. Schofield, R.K. 1935. The $\mathrm{pF}$ of the water in soil. Transactions of the 3rd International Congress of Soil Science. 2: 37-48. 
139. Sándor, R., Fodor, N., Rajkai, K. 2010. Növénytermesztési modellezés néhány léptékfüggő problémája. LII. Georgikon Napok Nemzetközi Tudományos Konferencia. Keszthely.

140. Sándor, R. és Fodor, N. 2012a. Simulation of Soil Temperature Dynamics with Models Using Different Concepts, The Scientific World Journal. Article ID 590287, 8 pages, 2012. doi:10.1100/2012/590287.

141. Sándor, R. és Fodor, N. 2012b. A hőmérséklet modellezésének néhány léptékfüggő problémája. I. Környezettudományi Doktori Iskolák Konferenciája. 2012. augusztus 3031. Budapest.

142. Sándor, R., Rajkai, K., Fodor, N. 2013. Homoktalaj nedvesség és hőmérséklet dinamikája növénytermesztési kísérlet kezeléseiben. II. ATK Napok. 2013. november 08. Martonvásár. p. 246-251.

143. Šimůnek, J., van Genuchten, M. TH., Šejna, M. 1998. The HYDRUS 6.0 Code for Simulating the One-dimensional Movement of Water, Heat, and Multiple Solutes in Variably-saturated Media. U.S. Salinity Laboratory. ARS-USDA. Riverside, CA.

144. Šimůnek, J., Šejna, M., Saito, H., Sakai, M., van Genuchten, M.Th. 2013. The HYDRUS-1D Software Package for Simulating the Movement of Water, Heat, and Multiple Solutes in Variably Saturated Media, Version 4.16, HYDRUS Software Series 3, Department of Environmental Sciences, University of California Riverside, Riverside, California, USA, pp. 340, 2013.

145. Singer, M.J. és Ugolini, F.C. 1976. Hydrophobicity in the soils of Fingley Lake, Washington. For. Sci. 22: 54-60.

146. Soetaert, K. és Petzoldt, T. 2010. Inverse modelling, sensitivity and monte carlo analysis in R using package FME. Journal of Statistical Software. 33: 1-28.

147. Soil Survey Staff. 1999. CHAPTER 1: The soils that we classify. In: Soil Taxonomy: A basic system of soil classification for making and interprting soil surveys. United States Department of Agriculture Handbook Natural Tesources Conservation Service Number $436 ; 10-14$.

148. Stefanovits, P., 1992. Talajtan. Mezőgazda Kiadó. p.380.

149. Stein, A., Staritsky, I.G., Bouma, J., van Eijnsbergen, A.C., Bregt, A.K. 1991. Simulation of moisture deficits and areal interpolation by universal cokriging. Water Resour. Res. 27: 1963-1973.

150. Stöckle, C.O., Donatelli, M., Nelson, R. 2003. CropSyst a cropping system simulation model. European Journal of Agronomy. 18: 289-307. 
151. Suleiman, A.A. és Ritchie J.T. 2001. Estimating saturated hydraulic conductivity from soil porosity. Trans. ASAE. 44: 235-239.

152. Szász, G. 1968. A globálsugárzás összegeinek meghatározása számítás útján. Debreceni Agrártudományi Föiskola Tudományos Közleményei. 14. 239-253.

153. Szász, G. és Tőkei, L. 1997. Meteorológia mezőgazdáknak, kertészeknek, erdészeknek. Mezőgazda Kiadó. p.722.

154. Szili-Kovács, T., Zsuposné Oláh, Á., Kátai, J., Villányi, I., Takács, T. 2009. Talajbiológiai és talajkémiai változók közötti összefüggések néhány tartamkísérlet talajában. Agrokémia és Talajtan. 58: 309-324.

155. Szücs L. 1963. A martonvásári kísérleti telep talajviszonyai. Agrokémia és Talajtan. 12: 299-318.

156. Topp, G.C. és Davis, J.L. 1985. Measurement of soil water content using time-domain reflectometry. Soil Sci. Soc. Am. J. 49: 19-24.

157. Tóth, B. 2010. Jellegzetes hazai talajok víztartó képességének számítása és jellemzése talajtérképi információk alapján. Ph.D. értekezés. Pannon Egyetem.Keszthely.

158. Twarakavi, N. K.C., Šimůnek, J., Seo, S. 2008. Evaluating interactions between groundwater and vadose zone using the HYDRUS- based flow package of MODFLOW. Vadose Zone Journal. 7: 757-768.

159. Upchurch, D.R., Wilding, L.P., Hartfield, J.L. 1988. Methods to evaluate spatial variability. In: Reclamation of Disturbed Lands. (Szerk.: Hossner, L.R.) CRC Press. Boca Raton, FL. pp. 201-229.

160. van Dam, J.C. 2000. Field scale water flow and solute transport. SWAP model concepts, parameter estimation and case studies. Ph.D. thesis, Wageningen Universiteit. p. 167.

161. van Genuchten, M.Th. 1980. A closed form equation for predicting the hydraulic conductivity of unsautrated soils. Soil Sci. Soc. Am. J. 44: 892-898.

162. van Grinsven, J.J.M., Dirksen, C., Bouten, W., 1985. Evaluation of the hot-air method for measuring soil water diffusivity. Soil Sci. Soc. Am. J. 49: 1093-1099.

163. Várallyay, Gy. 1973a. Berendezés bolygatatlan szerkezetü talajoszlopok hidraulikus vezetőképességének meghatározására. Agrokémia és Talajtan. 22: 23-36.

164. Várallyay, Gy. 1973b. A talaj nedvességpotenciálja és új berendezés annak meghatározására az alacsony (atmoszféra alatti) tenziótartományban. Agrokémia és Talajtan. 22: 1-22.

165. Várallyay, Gy. 1978. A talaj fizikai és vízgazdálkodási tulajdonságainak vizsgálata. MÉM Szabvány (MÉMSz-206), Budapest. 
166. Várallyay, Gy. 1987. A talaj vízgazdálkodása. Akadémiai doktori értekezés, Budapest.

167. Várallyay, Gy. 1993. Háromfázisú talaj kapilláris vezetőképességének (k) meghatározása. In: Talaj-és agrokémiai vizsgálati módszerkönyv 1. A talaj fizikai, vízgazdálkodási és ásványtani vizsgálata. (Szerk.: Buzás I.) INDA 4231 Kiadó. Budapest. pp. 205-219.

168. Várallyay, Gy. 2004. A talaj vízgazdálkodásának agroökológiai vonatkozásai. AGRO-21 Füzetek. 37: 50-70.

169. Várallyay, Gy. 2005a. Magyarország talajainak vízraktározó képessége. Agrokémia és Talajtan. 54: 2-24.

170. Várallyay, Gy. 2005b. Soil water management and the environment. In: Environmental Science and Technology in Hungary. Müszaki Kiadó. Budapest. CD ROM.

171. Várallyay, Gy., Makó, A., Hermann, T. 2009. Az Országos Mủtrágyázási Tartamkísérletek (OMTK) helyeinek talajtani jellemzése. In: Az Országos Mütrágyázási Tartamkísérletek (OMTK) kutatási eredményei (1967-2001). Szerk.: Debreczeni B., Németh, T. pp. 61-64.

172. Varga-Haszonits, Z. 1987. Agrometeorológiai információk és hasznosításuk. Mezőgazdasági Kiadó, Budapest, 1987. p. 248.

173. Waymire, W. és Gupta, V.K. 1981. The mathematical structure of rainfall representations. 1. a review of the stochastic rainfall models. Water Resour. Tes. 17: 1261-1272.

174. Webster, R. és Oliver, M.A. 1990. Statistical methods in soil and land resource survey. Spatial information systems. (Szerk.: Beckett, P.H.T., Burrough, P.A., Goodchild, M.F., Switzer, P.) Oxford University Press. p. 316.

175. Western, A.W., Grayson, R.B., Blöschl, G., Wilson, D.J. 2003. Spatial variability of soil moisture and its implications for scaling. In: Pachepsky, Y., Radcliffe D.E., Selim M.H. 2003. Scaling methods in soil physics. CRC Press. Pp. 119-142.

176. Witter, J.V. 1984. Heterogeneity of Dutch rainfall. $\mathrm{PhD}$ thesis. Wageningen Agricultural University, Wageningen, Netherlands. pp. 204.

177. Wösten, J.H.M., Lilly, A., Nemes, A., Le Bas, C. 1999. Development and use of dataset of hydraulic properties of European soils. Geoderma. 90: 169-185.

178. Wooding, R.A. 1968. Steady infiltration from a shallow circular pond. Water Resour. Res. 4: 1259-1273.

179. Yang, L.F. és Cai Z.C. 2006. Soil respiration during a soybean-growing season. Pedosphere. 16: 192-200. 
180. Zhang, R. 1997. Determination of soil sorptivity and hydraulic conductivity from the disk infiltrometer. Soil Sci. Soc. Am. J. 61:1024-1030.

181. Zhao, Y., Peth, S., Horn, R. 2008. Modeling of coupled water and heat fluxes in both unfrozen and frozen soils. The Second HYDRUS Workshop, 2008. március 28. Prága, Cseh Köztársaság. pp. 55-59.

182. Zheng, D., Hunt Jr. E.R., Running, S.W. 1993. A daily soil temperature model based on air temperature and precipitation for continental applications. Climate Research. 2: 183191.

183. Zhou, X., Persaud, N., Belesky, D.P., Clark, R.B. 2007. Significance of transients in soil temperature series. Pedosphere. 17: 766-775.

184. Zhu, J. és Mohanty, P. 2002. Spatial averaging of van Genuchten hydraulic parameters of steady-state flow in heterogeneous soils: a numerical study. Vadose Zone J. 1: 261272 . 


\section{0. ÖSSZEFOGLALÁS}

A globális trendek azt mutatják, hogy az időjárás a szélsőségek irányába fog változni. Ennek következtében gyakoribbak lesznek a víz stresszes időszakok (aszályos és belvizes periódusok). Ez ad különleges aktualitást a dolgozatomnak, melyben a talaj-növény-légkör rendszer modellezésének léptékfüggő problémáit taglalom a talaj vízgazdálkodási tulajdonságaiban, valamint megfigyelt hőmérsékleti adatsorokban. A léptékfüggés problémája azért merül fel, mert a valóság az változatos és változékony, az alkalmazott modelljeink és méréseink pedig diszkrétek. Ennek következtében a témakörön belüli vizsgálataimat két csoportba lehet sorolni: [1.] modellezésből fakadó léptékfüggés elemzése és [2.] mérésből eredő léptékfüggés feltárása. A modellek közül a $4 \mathrm{Mx}$ termésszimulációs modellt és a HYDRUS-1D hidrológiai modellt alkalmaztam. A méréseimet és vizsgálataimat 2009 és 2013 között a következő mintaterületeken végeztem el: Csólyospálos, Martonvásár, Nagyhörcsök, Örbottyán és Szurdokpüspöki.

A kutatás fő kérdései a következők voltak:

1. Befolyásolja-e a telítési vízvezető képesség értékét, és ha igen mekkora mértékben, a vizsgált minta mérete?

2. Milyen típusú változások jellemzik müvelést követően a telítési vízvezető képesség értékét homok és vályog fizikai féleségü talajokon?

3. Van-e pedon léptéken belüli változatossága a telítési vízvezető képesség és víztaszítás értékeknek homoktalajon illetve mi okozhatja annak víztaszítását?

4. Van-e különbség a mért és az eltérő léptékben szimulált talajhőmérséklet és talajnedvesség értékek között a növény- és hóborítottság függvényében?

5. Befolyásolja-e a szimulált beszivárgás és talajpárolgás értékét a modellben alkalmazott szelvényfelbontás, továbbá a szimulált növényi fejlődést a meteorológiai adatok felvételezési gyakorisága?

6. Van-e különbség a szimulált talajnedvesség eredményekben annak függvényében, hogy a több ismétlésben mért bemenő adatokat a modell szimulációt megelőzően átlagoljuk, vagy a különböző bemenő adatokkal kapott eredményeket a szimulációt követően átlagoljuk?

Kimutattuk, hogy a kumulatív csapadék mennyiségének függvényében a telítési vízvető képesség és térfogattömeg értékek változnak. A csólyospálosi mintaterületen 2 hónap alatt visszaáll az eredeti állapot. Azonban az őrbottyáni és martonvásári mintaterületeken egy vékony kérget figyeltünk meg, mely hatására néhány hét leforgása alatt lecsökkent a $\mathrm{K}_{\mathrm{S}}$ értéke a talajbolygatás előtti állapotra, azonban a térfogattömeg mérések eredményei nem 
támasztották alá ezt a gyors visszatömörödést. Vizsgálatok igazolták, hogy mind homok, mind pedig vályog talajok müvelést követő modellezése során célszerü figyelembe venni a térfogattömeg és a vízvezető képesség értékek időbeni változását a csapadék mennyiségének függvényében. Ezért javaslom, hogy a bemenő adatok esetében lehessen definiálni egy tér és időbeli változékonyságot, azért, hogy a modellek jobban közelítsék a valóságot.

Mérésekkel igazoltuk, hogy a homogén, reprezentatív elemi egységnek tekinthető, $1 \mathrm{~m}^{2}$-es területen belül a telítési vízvezető képesség több, mint másfél nagyságrendnyi különbséget mutatott a csólyospálosi mintaterületen, míg Örbottyánban fél nagyságrendnyi különbséget tapasztaltunk. A $K_{S}$ nagymértékü heterogenitása jelentősen befolyásolhatja a modell szimulációk eredményeit, mivel mind a 4Mx, mind pedig a HYDRUS-1D érzékeny a hidraulikus vezetőképesség értékére. Igazoltuk, hogy az őrbottyáni mintaterületen jól alkalmazható a MDI-es módszer. A csólyospálosi vizsgálataink esetében a Mini Disk Infiltrométeres mérések során a beszivárgás többnyire késleltetve indult meg, mely valószínü oka az lehet, hogy részben, vagy teljesen víztaszító pontra helyeztük a mérőmüszerünket. Összehasonlítottuk a teljes és az egyenletes beszivárgás megindulása utáni adatok felhasználásával kapott $K_{S}$ értékeket és fél nagyságrendnyi különbséget tapasztaltunk. Ezért javaslom, hogy víztaszító talajok esetében csak az intenzív beszivárgás megindulása utáni adatokat használjuk fel a telítési vízvezető képesség kiszámításához.

Megvizsgáltuk a csólyospálosi és őrbottyáni homoktalajok víztaszítását, mely során bizonyítottuk, hogy az őrbottyáni talaj jól nedvesíthető. A kísérleteink alapján a csólyospálosi talaj víztaszító, helyenként erősen víztaszító. A vizsgálataink nem erősítik meg azt a hipotézist, hogy a huminsav és fulvosav arány jó indikátora a talaj víztaszításának. Ezért az a feltétezésünk, hogy a csólyospálosi talaj víztaszítását nem a huminsavak okozzák, hanem a nagy mennyiségben előforduló még nem humifikálódott növényi maradványok.

Ha egy terület jelentős heterogenitással rendelkezik, akkor az egyik helyről elfolyó víz beszivároghat egy közeli helyen és az infiltrációs zónák közt száraz lencséket hagyhat. Ezek következtében durvább léptékben kisebb lehet a víztaszítás, mint a helyi értékek átlaga.

Összehasonlítottuk a hagyományos $100 \mathrm{~cm}^{3}$-es és a Booltink-féle $5650 \mathrm{~cm}^{3}$-es szurdokpüspöki mintákból mért $K_{S}$ átlag értékeket. A Booltink-féle (1991) módszer megbízhatóságát alátámasztja: (1) a nagy mintatömeg (2) a garantált telítettség és (3) a kontrollált peremfeltételek a $\mathrm{K}_{\mathrm{S}}$ mérés ideje alatt. Munka hipotézisként azt feltételeztük, hogy a laboratóriumban, nagy mintákon mért $\mathrm{K}_{\mathrm{S}}$ értékek közelítenek legpontosabban a vizsgált talaj telítési vízvezető képesség értékéhez (Fodor et al., 2011). A $\mathrm{K}_{\mathrm{S}}$ értékek kiértékelését 
követően szignifikáns különbséget tapasztaltunk a hidraulikus vezetőképesség értékekben és azok szórás értékeiben is. A vizsgálataink során a nagypatronos eljárás megbízhatóbb eredményt szolgáltatott, mint a hagyományos $100 \mathrm{~cm}^{3}$-es mintát alkalmazó módszer. Megállapítottuk, hogy a hidraulikus vezetőképesség értékét szignifikánsan befolyásolja a választott mérési módszer, illetve a mintavételezési egység nagysága homok, vályog és agyag fizikai féleségü talajokon.

Vizsgáltuk továbbá a napi hőösszeg számításának léptékfüggését. Ennek során rámutattunk, hogy a modellek által számolt hőfoknap egy idealizált esetre vonatkozik, amikor nem jelennek meg a finomabb felbontásban érzékelhető különbségek, ezáltal felül-, vagy alulbecsülhetjük az eredményt. Egy hosszabb időszakra vizsgálva a kumulált hőösszegek különbségét akár $10 \%$-os eltérést is tapasztalhatunk annak függvényében, hogy milyen rendszerességgel történt a léghőmérséklet felvételezése. Ez jelentős modellezési hibát eredményezhet, mivel a termésszimulációs modellek a napi két hőmérséklet adatból meghatározott hőösszegek alapján számítják ki a növények fenológiai fejlődésének ütemét.

Az őrbottyáni mintaterületen a LAI hatása egyértelműen kimutatható a talaj hőmérsékletének változásában. Azáltal, hogy csökkenti az átlagos talajhőmérsékletet és a szélsőértékeket is, a növényzet fejlettségi állapota befolyásolja a talaj hőmérséklet dinamikáját, ezért a LAI figyelembevétele fontos a talaj hőmérsékletének modellezése során (Sándor és Fodor, 2012a).

Eltérő térléptékü és számítási elvü modellekkel szimulált talajhőmérséklet értékeket a mért értékekhez hasolítottuk és azt tapasztaltuk, hogy a téli talajhőmérséklet modellezése esetén jelentkező hóréteg szigetelő hatását egyik modell sem szimulálta megfelelően, bár a HYDRUS-1D modellezett értékei jobban illeszkedtek a mért értékekhez. A 4Mx felbontása egy nagyságrenddel durvább, illetve talajhőmérsékletet leíró egyenlete egyszerübb, mint a HYDRUS-1D modellé, azonban az szimulált eredményei nem térnek el akkora mértékben, mint a felbontás közötti különbségböl várhatnánk. Amennyiben a 4Mx modell talajhőmérséklet leíró egyenletében módosítjuk a mélyebb rétegeket elérő hőenergia mennyiségét, akkor a kapott eredmények nem különböznek szignifikánsan a több kezdő- és peremfeltétet megkövetelő HYDRUS-1D modellezett eredményeitől (Sándor és Fodor, 2012a). Így javaslom, az ez irányú modellfejlesztést.

Az őrbottyáni homoktalajon végzett vizsgálataink alapján nem mutatható ki szignifikáns különbség a cm-es és dm-es felbontású HYDRUS-1D modellezett talajnedvesség értékei között. 
Megállapítható, hogy egy átlagos csapadékmennyiségü és -eloszlású évben (2011ben) nincs szignifikáns különbség a mért és modellezett talajnedvesség értékek között. Azonban extrém aszályos (2012-es), vagy csapadékos (2010-es) vegetációs időszakokban a szimulált és mért talajnedvesség értékek között szignifikáns különbséget tapasztaltunk. Ezek alapján megállapítható, hogy a HYDRUS-1D nem szimulálta megfelelően az extrém évjárathatásokat, melyek gyakorisága a jövőben emelkedni fog.

Vizsgáltuk a beszivárgás és talajpárolgás modellezésének térbeli léptékfüggését. Egy zivatart követően szimulált talajpárolgás során az $1 \mathrm{~cm}$ vastagnak meghatározott felső réteg sokkal hamarabb kiszáradt, mint a $10 \mathrm{~cm}$-nek definiált. Ennek következtében, az evaporáció szimulálása során szignifikáns különbséget tapasztalhatunk annak függvényében, hogy milyen az alkalmazott modellünk szelvényfelbontása. A $0-10 \quad \mathrm{~cm}$ rétegben szimulált nedvességtartalom változása jelentősebb eltérést mutatott az idő függvényében $1 \mathrm{~cm}$, illetve $10 \mathrm{~cm}$ vastagságúnak definiált felső talajrétegek esetén. Már csupán azáltal jelentős hibával terhelhetjük a modell szimulációnk eredményét, hogy milyen felbontású modellt használunk.

Az $1 \mathrm{~cm}$ vastagnak meghatározott felső réteg kiszárad, és a hidraulikus vezetőképesség értéke drasztikusan lecsökken, ezért nem továbbít hatékonyan vizet a légkör felé. Így leáll a felfelé áramlás és csökken összességében a párolgás. Ez a folyamat a valóságban sokszor menti meg a talajt és a növényeket a kiszáradástól, tehát aszályos időszakban fontos ennek a folyamatnak a leírása és alkalmazása modellekben.

Az őrbottyáni homoktalajon megvizsgáltuk a térbeli heterogenitás következtében előálló modellezési problémákat különböző szimulációs technikák esetén. A HYDRUS-1D szimulációi során jelentős eltérést tapasztaltunk annak függvényében, hogy a modell futtatása előtt átlagoltuk a több ismétlésben mért hidraulikus vezetőképesség értékeket (IC), vagy az ismétlésekben mért $\mathrm{K}_{\mathrm{S}}$ értékekkel végeztük a modell szimulációkat és az egyes szimulációk utáni kimenetek átlagát (CI) vettük alapul. A CI módszer javasolt, még ha több számítási munkát is igényel a felhasználótól, mivel az IC elfedi a térbeli heterogenitásból adódó különbségeket és a már pedon léptéken is megjelenő léptékfüggést. 


\section{SUMMARY}

According to the global trend both the frequency and the intensity of weather extremes such as severe drought, heat waves and periods of heavy rainfall are expected to increase due to the climate change. Therefore my thesis is relevant which describes some aspects of the scalerelated problems of the soil-plant-atmosphere system. Specific topics were investigated with respect to soil temperature and water content as well as to observed meteorological data. Scale-related problems are caused by the fact that the reality changes both in space and time while the models and measurements are discrete, applying a certain spatial and/or temporal resolution. Consequently, the investigations of this subject could be arranged in two groups: (1) analyses of scale-related problems of modeling (2) examinations of scale related problems of measurements. The 4Mx crop model as well as the HYDRUS-1D hydrological model were applied in the study. Measurements and investigations were carried out in laboratory as well as in field experiments, in irrigated and fertilized field trials, between 2009 and 2013. The experiment sites were: Csólyospálos (sandy soil), Martonvásár (sandy loam soil), Nagyhörcsök (loam soil), Örbottyán (sandy soil) and Szurdokpüspöki (clay soil).

The following questions were investigated in the research:

1. Does the measured saturated hydraulic conductivity depend on the sample size?

2. How does the hydraulic conductivity change after cultivation on sandy and loamy soils?

3. Is there any heterogenity of hydraulic conductivity and water repellency values within pedon scale on sandy soil and what factors may cause its water repellency?

4. Is there any difference between measured and simulated values of soil temperature as well as of soil water content at different scales as a function of crop and snow cover?

5. Are the simulated infiltration and soil evaporation results influenced by the applied soil profile discretization? Is the simulated plant phenological development effected by the frequency of meteorological data recording?

6. Is there any difference between the model result obtained with the average of different inputs and the average of model results obtained after the simulations (using different inputs).

In the field experiments, it could be detected that the hydraulic conductivity $\left(\mathrm{K}_{\mathrm{S}}\right)$ and bulk density were changed with the cumulative precipitation after cultivation. The soil at the pilot area of Csólyospálos was re-compacted to the original state within two months. At the 
Örbottyán and Martonvásár experimental sites, a thin crust layer was formed on the soil surface which resulted in a fast decrease of saturated hydraulic conductivity within few weeks, but the bulk density measurements did not support the rapid re-compaction of the disturbed system. Based on the results, the consideration of the temporal variability of hydraulic conductivity as well as of bulk density after cultivation as a function of precipitation in model calculations is indispensable. Soil hydraulic conductivity and bulk density are not constant over time, as assumed in most hydrological and crop models. Therefore, the development of these models to take into account the spatial heterogenity and temporal variability of these input data is indispensable as well.

The spatial heterogeneity of $1 \mathrm{~m}^{2}$ soil surface was experimentally identified for two hydraulic properties although, this area is usually considered as a 'homogeneous' soil mapping unit (pedon). The measurements showed that the saturated hydraulic conductivity had 1.5 an 0.5 order of magnitude difference within $1 \mathrm{~m}^{2}$ at Csólyospálos and Örbottyán, respectively. The results of a model simulation could be influenced by the considerable variability of $\mathrm{K}_{\mathrm{S}}$ values because both 4Mx and HYDRUS-1D are sensitive to the saturated hydraulic conductivity input parameter.

The sandy soils of Csólyospálos and Örbottyán pilot areas were investigated with Water Drop Penetration Time Test. The Örbottyán soil was found to be a non-repellent one. Our investigations showed that the soil of Csólyospálos was strongly or even severely water repellent at some points. Our findings weren't confirmed the hypothesis that the humic acid to fulvo acid ratio is a good indicator of the soil water repellency (Singer and Ugolini, 1976). Therefore, I assumed that the soil water repellency at Csólyospálos could be attributed to the large quantity of non-degraded organic compounds. Generally, delayed infiltration was observed with the Mini Disk Infiltrometer (MDI) at Csólyospálos experimental site. A possible reason for it could be that the soil was partially or totally repellent under the MDI. First, Ks values were determined based on raw infiltration data collected during the total measurement time then, raw data recorded after the start of the rapid infiltration was used for determining the Ks. A half order of magnitude difference was detected between the results of the two methods. On water repellent soils, the actual measurements should be started after the beginning of the rapid infiltration in order to obtain more precise saturated hydraulic conductivity values with MDI. I concluded that the Mini Disk Infiltrometer could be applied for non-repellent soils (e.g. Örbottyán). If the area is heterogeneous, dry lenses may remain in the soil during infiltration and some of the precipitation may run off and infiltrate in the 
neighboring area. Consequently the bulk large scale water repellency can be less than the mean of small-scale values.

Determination of the saturated hydraulic conductivity from five $100 \mathrm{~cm}^{3}$ (Várallyay, 1973a) and five $5650 \mathrm{~cm}^{3}$ (Booltink et al., 1991) undisturbed soil samples were compared for three soil types: sandy soil of Örbottyán, silt soil of Nagyhörcsök and clay soil of Szurdokpüspöki. The method of Booltink et al. (1991) is considered to be more precise due to (a) the larger sample volume, (b) the guaranteed saturation and (c) the controlled boundary conditions during the determination of the $\mathrm{K}_{\mathrm{S}}$. The $\mathrm{K}_{\mathrm{S}}$ values, measured on the large samples could give the best estimation of the saturated hydraulic conductivity values of the investigated soils (Fodor et al., 2011) according to our working hypothesis. Significant differences were found both in the average and the in standard deviation of the measured hydraulic conductivity values for each soil. It was proved that the value of saturated hydraulic conductivity was influenced by the applied sampling volume.

The scale-dependence of the calculated daily thermal time was also investigated at the Örbottyán pilot area. The sinusoidal diurnal course which is based on minimum and maximum daily temperatures values is an idealized case where daily temperature anomalies could be overlooked while these anomalies could be taken into account if fine resolution (e.g. 5 minute) temperature data would be used. Consequently, daily thermal time values could be over- or underestimated if only daily-step temperature data is used for the calculations. The difference between the cumulative thermal time values calculated with the two investigated methods could be more than $10 \%$ during a 10-days period. It could induce significant modeling error as plant phenological development is based on the daily thermal time which is usually calculated by using only two daily temperature data.

Considerable differences in the leaf area indices were observed in different treatments of the experiment at the end of the canopy development at the Örbottyán study site. The welldeveloped (with high LAI) vegetation reduces both the average soil temperature and its diurnal amplitude therefore, considering the LAI values are important in soil temperature modeling (Sándor and Fodor, 2012a).

Measured soil temperatures data were compared to simulated soil temperature calculated by models with different spatial resolution and concept. Neither HYDRUS-1D nor 4Mx simulated adequately the heat transport in the soil, although HYDRUS-1D provided more accurate soil temperature estimations. Soil temperature values calculated by the HYDRUS-1D 
and the modified $4 \mathrm{Mx}$ model were not found to be significantly different. In spite of the fact that the spatial resolution of the $4 \mathrm{Mx}$ model is one order of magnitude larger than that of the HYDRUS-1D, the modified 4Mx simulation results did not deviate from measured data to such an extent that could be expected according to the resolution and concept difference. The seasonal snow cover could significantly modify the freezing of soil as it builds up an isolating layer. The drop of soil temperature was moderated under the snow cover with low thermal conductivity. Thus, I propose to develop the $4 \mathrm{Mx}$ model to eliminate the above mentioned discrepancy.

According to our investigations insignificant differences were found between the soil water content values simulated with the $\mathrm{cm}$ - and the dm resolution versions of HYDRUS-1D.

Statistically significant differences between the measured and simulated (HYDRUS-1D) soil water contents were observed under different weather conditions such as extreme rainy weather in 2010 or severe drought period in 2012. The series of measured and calculated soil water content were similar, if the distribution of weather condition was average (without long dry or wet spells) such as in 2011. Simulated water content values may significantly differ from measured values during prolonged extreme weather conditions the frequency of which is expected to increase in the future.

The infiltration and the soil evaporation were simulated with $4 \mathrm{Mx}$ model where the top most soil layer was defined to $10,9,8,7,6,5,4,3,2,1 \mathrm{~cm}$ thick. During the simulated evaporation following a rainstorm event the $1 \mathrm{~cm}$ thick upper layer was dried out sooner than the $10 \mathrm{~cm}$ thick layer though, the total water content of the $0-10 \mathrm{~cm}$ layer was considerably higher in the first case. As a consequence, significant differences were obtained owing to the model resolution during the simulation of evaporation. Depending on whether the surface layer thickness was defined to $1 \mathrm{~cm}$, or $10 \mathrm{~cm}$, the simulated water content changes showed major difference as a function of time. The spatial resolution of the model could be a source of error (or at least uncertainty).

The hydraulic conductivity is drastically decreased if the $1 \mathrm{~cm}$ thick uppermost layer dried out. Consequently, the upward flow is stopped so the amount of evaporation is reduced. This process can protect the soil and plants from drying and withering in nature conditions. Therefore, considering the mentioned process is important in modeling.

Spatial heterogeneity related modeling problems were investigated with HYDRUS-1D using data from the Örbottyán experimental site. Depending on whether the measured saturated 
hydraulic conductivity values were averaged before the simulation (Interpolate first, Calculate later; $I C$ ) or the model results obtained with the different measured $\mathrm{K}_{\mathrm{S}}$ data were averaged after the simulations (Calculate first, Interpolate later; $C I$ ), considerably different infiltration and surface runoff results were obtained. The CI method is recommended, despite the fact that it requires more calculation from the user, because the IC method may hide the effect of spatial heterogeneity that appears even on pedon scale. 


\section{MELLÉKLETEK}

\section{A MELLÉKLETEK LISTÁJA:}

1. melléklet: Az őrbottyáni mintaterületen feltárt talajszelvény leírása és jellemzői

2. melléklet: Az örbottyáni 2. mintaterület szemcseméret eloszlás és Arany-féle kötöttség értékei, 2010. április 16-án

3. melléklet: A talaj alapparaméterek vizsgálati jegyzőkönyve. A mintavétel helye és időpontja: Örbottyán, 2. mintaterület, 2010. április 16.

4. melléklet: Talajfizikai vizsgálati jegyzőkönyv. A mintavétel helye és időpontja: Örbottyán, 2. mintaterület, 2010. április 16.

5. melléklet: A mintaterületek 0-30 cm-es talajrétegében mért 3 frakciós mechanikai összetétel vizsgálat eredményei

6. melléklet: A mintaterületek 0-30 cm-es szintjének átlagolt kémiai és fizikai talajjellemző értékei a kísérletek beállítását megelőzően

7. melléklet: Az őrbottyáni 2. mintaterület agrotechnikai bemutatása

8. melléklet: A csólyospálosi mintaterületen feltárt talajszelvény leírása és jellemzői

9. melléklet: A martonvásári mintaterületen feltárt talajszelvény leírása és jellemzői

10. melléklet: A nagyhörcsöki mintaterületen feltárt talajszelvény leírása és jellemzői

11. melléklet: A szurdokpüspöki mintaterületen feltárt talajszelvény leírása és jellemzői

12. melléklet: A léptékfüggés megjelenése a meteorológiai adatsorok felhasználásakor c. fejezet bemenő adatai és paraméterei

13. melléklet: Eltérő térléptékü modellekkel számított talajhőmérséklet értékek összehasonlítása c. fejezet HYDRUS-1D bemenő adatai és paraméterei

14. melléklet: Eltérő térléptékü modellekkel számított talajhőmérséklet értékek összehasonlítása c. fejezet $4 \mathrm{Mx}$ és módosított $4 \mathrm{Mx}$ bemenő adatai és paraméterei

15. melléklet: Mért és szimulált talajnedvesség értékek összehasonlítása, növénytermesztési kísérlet kezelésében c. fejezet bemenő adatai és paraméterei

16. melléklet: Beszivárgás és talajpárolgás modellezésének térbeli léptékfüggése c. fejezet bemenő adatai és paraméterei

17. melléklet: A térbeli heterogenitás következtében előálló modellezési problémák, különböző szimulációs technikák esetén c. fejezet bemenő adatai

18. melléklet: A csólyospálosi mintaterületen mért csapadék mennyisége 2011.július 24. és 2011. október 14. között 
19. melléklet: Az őrbottyáni mintaterületen mért csapadék mennyisége 2011. április 18. és 2011. augusztus 9. között

20. melléklet: A martonvásári mintaterületen mért csapadék mennyisége 2011. június 7. és 2011. szeptember 22. között

21. melléklet: A talajok víztaszítás értékének térbeli változatossága Csólyospálos mintaterületén, 2012. május 3-án és Örbottyánban 2012. május 31-én, Dekker és Ritsema (1996) alapján

22. melléklet: A teljes (a) és korrigált (b) mérési idő felhasználásával kiszámított $K_{S}$ értékek térbeli változatossága Csólyospáloson

23. melléklet: A teljes mérési idő felhasználásával kiszámított $K_{S}$ értékek térbeli változatossága Örbottyánban

24. melléklet: Mért és cm-es, illetve dm-es felbontású szimulált talajnedvesség értékek összehasonlítása 0-10 cm-es mélységben, Örbottyánban

25. melléklet: Mért és cm-es, illetve dm-es felbontású szimulált talajnedvesség értékek összehasonlítása 0-80 cm-es mélységben, Őrbottyánban 
Az őrbottyáni mintaterületen feltárt talajszelvény leírása és jellemzői

Feltárást készítette:

Dátum:

Földhasználat:

Kitettség:

Talajképző kőzet:

Szelvény mélysége:

Humuszos szint mélysége:

Talajtípus:
Sándor Renáta

2010.04.16.

ugar

közel sík felszín

öntés homok

$90 \mathrm{~cm}$

$35 \mathrm{~cm}$

Karbonátos humuszos homoktalaj

WRB: Arenosols, Cambisols

A szelvény morfológiai leírása:

\begin{tabular}{|c|c|l|}
\hline $\begin{array}{c}\text { Genetikus } \\
\text { réteg jele }\end{array}$ & $\begin{array}{c}\text { Mélység } \\
\mathbf{c m}\end{array}$ & \multicolumn{1}{|c|}{ Szelvény leírás } \\
\hline $\mathrm{A}$ & $0-30 \mathrm{~cm}:$ & $\begin{array}{l}\text { Szín: világosbarna, száraz. } \\
\text { Fizikai talajféleség: homok. Szerkezet: szerkezet nélküli } \\
\text { homok. A feltalajban gyökér és növénymaradvány. } \\
\text { Aranyféle kötöttség: 25; } \mathrm{pH}: 7,5 ; \mathrm{CaCO}_{3}: 1,4 ; \text { humusz: 0,9\%. } \\
\text { Átmenet a következö szintbe: fokozatos. }\end{array}$ \\
\hline $\mathrm{B}$ & $30-65 \mathrm{~cm}:$ & $\begin{array}{l}\text { Szín: világosbarna, sárgásbarna, száraz. Fizikai talajféleség: } \\
\text { homok. Szerkezet: szerkezet nélküli homok. } \\
\text { Aranyféle kötöttség: 24; pH: 7,6; CaCO } \mathrm{CO}_{3}: 2,1 \% \text {, humusz: 0,7 } \\
\% \text {. Átmenet a következö szintbe: fokozatos } \\
\text { Egy-két kavicsdarab megfigyelhetö. }\end{array}$ \\
\hline $\mathrm{C}$ & $65-\mathrm{cm}:$ & $\begin{array}{l}\text { Szín: sárga, száraz. Fizikai talajféleség: homok. Szerkezet: laza, } \\
\text { szerkezet nélküli homok. } \\
\text { Arany-féle kötöttség: } 25 ; \mathrm{pH}: 7,8 ; \mathrm{CaCO}_{3}: 7,5 \%, \text { humusz: } 0,5 . \\
\text { Több kavicsdarab. }\end{array}$ \\
\hline
\end{tabular}


Az őrbottyáni 2. mintaterület szemcseméret eloszlás és Arany-féle kötöttség értékei, 2010. április 16-án

\begin{tabular}{|c|c|c|c|c|c|}
\hline Parcella & Mintavétel mélysége $[\mathrm{cm}]$ & homok & iszap & agyag & $\mathbf{K}_{(\mathbf{A})}$ \\
\hline \multirow{3}{*}{1} & $0-30$ & 92,26 & 2,81 & 4,92 & 24 \\
\hline & $30-60$ & 92,28 & 3,05 & 4,66 & $<24$ \\
\hline & $60-90$ & 93,51 & 2,72 & 3,76 & 24 \\
\hline \multirow{3}{*}{2} & $0-30$ & 91,47 & 3,37 & 5,15 & $<24$ \\
\hline & $30-60$ & 91,86 & 3,13 & 5,02 & $<24$ \\
\hline & $60-90$ & 94,77 & 2,17 & 3,07 & $<24$ \\
\hline \multirow{3}{*}{3} & $0-30$ & 91,09 & 3,36 & 5,57 & 26 \\
\hline & $30-60$ & 91,81 & 3,20 & 4,99 & 24 \\
\hline & $60-90$ & 90,44 & 3,81 & 5,75 & 25 \\
\hline \multirow{3}{*}{4} & $0-30$ & 88,93 & 4,85 & 6,22 & 25 \\
\hline & $30-60$ & 89,87 & 3,90 & 6,23 & 24 \\
\hline & $60-90$ & 92,91 & 3,05 & 4,04 & 26 \\
\hline \multirow{3}{*}{5} & $0-30$ & 88,01 & 4,89 & 7,09 & 25 \\
\hline & $30-60$ & 88,65 & 4,81 & 6,54 & $<24$ \\
\hline & $60-90$ & 83,85 & 6,68 & 9,46 & 25 \\
\hline \multirow{3}{*}{6} & $0-30$ & 87,03 & 5,73 & 7,26 & 26 \\
\hline & $30-60$ & 89,34 & 4,76 & 5,90 & 25 \\
\hline & $60-90$ & 93,93 & 2,43 & 3,65 & 24 \\
\hline \multirow{3}{*}{7} & $0-30$ & 87,60 & 5,20 & 7,20 & 25 \\
\hline & $30-60$ & 88,19 & 4,70 & 7,11 & $<24$ \\
\hline & $60-90$ & 89,56 & 4,78 & 5,66 & 24 \\
\hline \multirow{3}{*}{8} & $0-30$ & 86,15 & 6,65 & 7,21 & 25 \\
\hline & $30-60$ & 89,75 & 4,70 & 5,56 & 24 \\
\hline & $60-90$ & 95,07 & 1,73 & 3,20 & $<24$ \\
\hline
\end{tabular}

A vizsgálatok Buzás (1993) szerint történtek. 
A talaj alapparaméterek vizsgálati jegyzőkönyve. A mintavétel helye és időpontja: Őrbottyán, 2. mintaterület, 2010. április 16.

\begin{tabular}{|c|c|c|c|c|c|}
\hline Parcella & Mélység & $\mathbf{p H - K C l}$ & $\begin{array}{c}\boldsymbol{\Sigma} \mathbf{~ s o ́} \\
\mathbf{m} / \mathbf{m} \%\end{array}$ & $\begin{array}{c}\mathbf{C a C O} \\
\mathbf{m} / \mathbf{m} \%\end{array}$ & $\begin{array}{c}\mathbf{H} \\
\mathbf{m} / \mathbf{m} \%\end{array}$ \\
\hline \multirow{4}{*}{1.} & $0-30$ & 7,47 & $<0.02$ & 0,21 & 0,775 \\
\cline { 2 - 6 } & $30-60$ & 7,54 & $<0.02$ & 0,37 & 0,513 \\
\cline { 2 - 6 } & $60-90$ & 7,78 & $<0.02$ & 2,06 & 0,484 \\
\hline \multirow{3}{*}{2.} & $0-30$ & 7,52 & $<0.02$ & 1,11 & 0,867 \\
\cline { 2 - 6 } & $30-60$ & 7,62 & $<0.02$ & 0,74 & 0,538 \\
\cline { 2 - 6 } & $60-90$ & 8,10 & $<0.02$ & 14,0 & 0,285 \\
\hline \multirow{4}{*}{3.} & $0-30$ & 7,53 & $<0.02$ & 0,95 & 0,899 \\
\cline { 2 - 6 } & $30-60$ & 7,67 & $<0.02$ & 1,61 & 0,558 \\
\cline { 2 - 6 } & $60-90$ & 7,56 & $<0.02$ & 0,33 & 0,635 \\
\hline \multirow{3}{*}{4.} & $0-30$ & 7,51 & $<0.02$ & 1,52 & 0,891 \\
\cline { 2 - 6 } & $30-60$ & 7,58 & $<0.02$ & 0,86 & 0,679 \\
\cline { 2 - 6 } & $60-90$ & 7,86 & $<0.02$ & 7,05 & 0,479 \\
\hline
\end{tabular}

\begin{tabular}{|c|c|c|c|c|c|}
\hline \multirow{2}{*}{ Parcella } & Mélység & $\mathbf{p H - K C l}$ & $\begin{array}{c}\boldsymbol{\Sigma} \mathbf{s o ́} \\
\mathbf{m} / \mathbf{m} \%\end{array}$ & $\begin{array}{c}\mathbf{C a C O} \\
\mathbf{m} / \mathbf{m} \%\end{array}$ & $\begin{array}{c}\mathbf{H} \\
\mathbf{m} / \mathbf{m} \%\end{array}$ \\
\hline \multirow{3}{*}{5.} & $0-30$ & 7,39 & $<0.02$ & 0,74 & 1,00 \\
\cline { 2 - 6 } & $30-60$ & 7,55 & $<0.02$ & 0,70 & 0,805 \\
\cline { 2 - 6 } & $60-90$ & 7,49 & $<0.02$ & 0,82 & 0,880 \\
\hline \multirow{4}{*}{6.} & $0-30$ & 7,52 & $<0.02$ & 1,93 & 0,984 \\
\cline { 2 - 6 } & $30-60$ & 7,65 & $<0.02$ & 3,52 & 0,716 \\
\cline { 2 - 6 } & $60-90$ & 7,96 & $<0.02$ & 13,7 & 0,410 \\
\hline \multirow{4}{*}{7.} & $0-30$ & 7,45 & $<0.02$ & 1,35 & 1,01 \\
\cline { 2 - 6 } & $30-60$ & 7,56 & $<0.02$ & 0,98 & 0,891 \\
\cline { 2 - 6 } & $60-90$ & 7,69 & $<0.02$ & 2,54 & 0,767 \\
\hline \multirow{3}{*}{8.} & $0-30$ & 7,45 & $<0.02$ & 3,65 & 1,05 \\
\cline { 2 - 6 } & $30-60$ & 7,73 & $<0.02$ & 8,11 & 0,691 \\
\cline { 2 - 6 } & $60-90$ & 8,14 & $<0.02$ & 19,8 & 0,271 \\
\hline
\end{tabular}

Az alaptulajdonság vizsgálatok során alkalmazott módszerek és bizonytalanságuk:

\begin{tabular}{|c|c|c|c|}
\hline Vizsgálat neve & Módszer & Készülék & Bizonytalanság \\
\hline $\mathrm{pH}(\mathrm{KCI})$ & MSZ-08-0206-2:1978 & Digitális pH-mérö, Radelkis OP-300, Sentron & 0,05 \\
\hline Összes só & MSZ-08-0206-2:1978 & Konduktométer, RadelkisOK-102/1 & $5-7.5$ rel. \% \\
\hline $\mathrm{CaCO}_{3}$ & MSZ-08-0206-2:1978 & Kalciméter, LABOR MIM & $5-7.5$ rel. $\%$ \\
\hline Humusz & MSZ-08-0452:1980 & Spectronic Genesys 5 & $2.5-7.5$ rel. \% \\
\hline
\end{tabular}


Talajfizikai vizsgálati jegyzőkönyv. A mintavétel helye és időpontja: Őrbottyán, 2. mintaterület, 2010. április 16.

\begin{tabular}{|c|c|c|c|c|c|c|c|c|c|c|c|c|}
\hline Parcella & Mélység & $\begin{array}{c}\begin{array}{c}\text { Térfogattömeg } \\
\mathrm{g} / \mathrm{cm}^{3}\end{array} \\
\end{array}$ & pF 0 & pF 0,4 & pF 1,0 & pF 1,5 & pF 2,0 & pF 2,3 & pF 2,7 & pF 3,4 & pF 4,2 & $\begin{array}{c}\text { Aktuális nedvesség } \\
\mathbf{m} / \mathbf{m} \%\end{array}$ \\
\hline \multirow{3}{*}{1} & $5-10$ & 1,5 & 41,0 & 39,9 & 38,5 & 37,1 & 33,9 & 14,6 & 10,5 & 3,7 & 2,2 & 9,4 \\
\hline & $35-40$ & 1,6 & 34,9 & 34,4 & 33,3 & 30,4 & 27,1 & 11,3 & 9,1 & 4,0 & 2,4 & 8,1 \\
\hline & $65-70$ & 1,6 & 36,4 & 35,7 & 34,0 & 31,6 & 23,8 & 8,1 & 6,3 & 3,0 & 1,7 & 6,0 \\
\hline \multirow{3}{*}{2} & $5-10$ & 1,5 & 43,7 & 43,1 & 41,2 & 39,1 & 36,7 & 14,8 & 11,3 & 4,1 & 2,4 & 9,6 \\
\hline & $35-40$ & 1,6 & 35,4 & 34,6 & 33,1 & 30,4 & 27,5 & 12,4 & 9,7 & 4,3 & 2,7 & 8,2 \\
\hline & $65-70$ & 1,6 & 35,3 & 34,6 & 33,1 & 31,3 & 24,7 & 6,9 & 5,7 & 2,9 & 1,9 & 6,2 \\
\hline \multirow{3}{*}{3} & $5-10$ & 1,6 & 39,5 & 38,6 & 36,9 & 36,0 & 34,2 & 11,6 & 10,1 & 4,4 & 2,7 & 9,7 \\
\hline & $35-40$ & 1,6 & 33,2 & 32,6 & 31,1 & 29,0 & 24,6 & 13,5 & 10,8 & 4,4 & 2,8 & 8,9 \\
\hline & $65-70$ & 1,6 & 34,2 & 34,0 & 32,8 & 31,3 & 26,4 & 10,0 & 8,8 & 4,4 & 2,7 & 7,7 \\
\hline \multirow{3}{*}{4} & $5-10$ & 1,6 & 38,7 & 37,8 & 36,3 & 35,1 & 32,2 & 18,7 & 16,4 & 5,7 & 3,3 & 11,4 \\
\hline & $35-40$ & 1,7 & 32,7 & 32,5 & 31,3 & 30,0 & 26,9 & 17,3 & 13,8 & 6,4 & 4,0 & 10,0 \\
\hline & $65-70$ & 1,6 & 35,6 & 35,2 & 33,9 & 30,4 & 26,0 & 11,9 & 10,1 & 4,2 & 2,7 & 6,8 \\
\hline \multirow{3}{*}{5} & $5-10$ & 1,6 & 38,3 & 38,1 & 36,7 & 35,7 & 33,6 & 21,2 & 18,1 & 4,9 & 3,0 & 11,7 \\
\hline & $35-40$ & 1,6 & 36,8 & 36,6 & 35,2 & 34,0 & 31,2 & 11,9 & 9,8 & 5,0 & 3,1 & 9,9 \\
\hline & $65-70$ & 1,6 & 36,2 & 36,1 & 35,4 & 32,7 & 29,2 & 12,6 & 10,2 & 5,1 & 3,1 & 9,3 \\
\hline \multirow{3}{*}{6} & $5-10$ & 1,6 & 38,7 & 38,3 & 36,8 & 35,7 & 34,3 & 19,7 & 16,2 & 6,8 & 3,7 & 13,1 \\
\hline & $35-40$ & 1,6 & 35,4 & 35,0 & 33,0 & 30,2 & 24,7 & 15,2 & 13,3 & 6,8 & 3,8 & 11,5 \\
\hline & $65-70$ & 1,6 & 36,6 & 36,5 & 35,4 & 33,3 & 28,9 & 15,3 & 11,1 & 3,8 & 2,5 & 6,9 \\
\hline \multirow{3}{*}{7} & $5-10$ & 1,5 & 41,3 & 40,2 & 38,6 & 37,4 & 34,3 & 21,5 & 17,9 & 5,8 & 3,3 & 12,0 \\
\hline & $35-40$ & 1,6 & 35,9 & 35,5 & 34,4 & 31,9 & 27,0 & 13,4 & 11,4 & 5,5 & 3,3 & 10,7 \\
\hline & $65-70$ & 1,5 & 40,2 & 39,9 & 38,5 & 31,5 & 26,1 & 12,3 & 10,4 & 5,3 & 3,2 & 9,8 \\
\hline \multirow{3}{*}{8} & $5-10$ & 1,7 & 36,0 & 35,5 & 34,0 & 33,0 & 30,8 & 20,5 & 18,2 & 7,3 & 4,0 & 13,6 \\
\hline & $35-40$ & 1,7 & 35,0 & 34,5 & 33,5 & 32,1 & 28,0 & 19,6 & 15,7 & 7,2 & 4,2 & 12,0 \\
\hline & $65-70$ & 1,6 & 36,2 & 35,6 & 34,4 & 32,4 & 25,3 & 12,1 & 8,6 & 2,3 & 1,5 & 5,2 \\
\hline
\end{tabular}


A mintaterületek 0-30 cm-es talajrétegében mért 3 frakciós mechanikai összetétel vizsgálat eredményei

\begin{tabular}{|c|c|c|c|c|c|c|}
\hline & \multicolumn{3}{|c|}{ ÁTLAGOS SZEMCSEÖSSZETÉTEL } & \multicolumn{3}{|c|}{ SZEMCSEÖSSZETÉTEL (ismétlések) } \\
\hline & homok & iszap & agyag & homok & iszap & agyag \\
\hline HELY & $2-0,05 \mathrm{~mm}(\%)$ & $0,05-0,002 \mathrm{~mm}(\%)$ & $<0,002 \mathrm{~mm}(\%)$ & $2-0,05 \mathrm{~mm}(\%)$ & $0,05-0,002 \mathrm{~mm}(\%)$ & $<0,002 \mathrm{~mm}(\%)$ \\
\hline \multirow{8}{*}{$\begin{array}{l}\text { ŐRBOTTYÁN } \\
\text { 2. sz. mintahely }\end{array}$} & \multirow{8}{*}{85,66} & \multirow{8}{*}{$\mathbf{8 , 0 1}$} & \multirow{8}{*}{6,33} & 89,56 & 5,51 & 4,92 \\
\hline & & & & 88,49 & 6,35 & 5,15 \\
\hline & & & & 88,72 & 5,73 & 5,57 \\
\hline & & & & 85,87 & 7,91 & 6,22 \\
\hline & & & & 84,46 & 8,44 & 7,09 \\
\hline & & & & 83,45 & 9,31 & 7,26 \\
\hline & & & & 83,44 & 9,36 & 7,20 \\
\hline & & & & 81,33 & 11,47 & 7,21 \\
\hline \multirow{5}{*}{ NAGYHÖRCSÖK } & \multirow{5}{*}{18,93} & \multirow{5}{*}{55,95} & \multirow{5}{*}{25,12} & 18,68 & 56,24 & 25,08 \\
\hline & & & & 18,04 & 57,35 & 24,61 \\
\hline & & & & 19,19 & 55,65 & 25,16 \\
\hline & & & & 19,52 & 54,59 & 25,90 \\
\hline & & & & 19,21 & 55,95 & 24,84 \\
\hline \multirow{5}{*}{ SZURDOKPÜSPÖKI } & \multirow{5}{*}{13,22} & \multirow{5}{*}{41,81} & \multirow{5}{*}{44,97} & 12,14 & 42,86 & 45,01 \\
\hline & & & & 10,56 & 43,02 & 46,43 \\
\hline & & & & 12,14 & 41,70 & 46,16 \\
\hline & & & & 15,00 & 41,40 & 43,61 \\
\hline & & & & 16,25 & 40,09 & 43,65 \\
\hline \multirow{6}{*}{ CSÓLYOSPÁLOS } & \multirow{6}{*}{95,01} & \multirow{6}{*}{2,56} & \multirow{6}{*}{2,41} & 95,37 & 2,21 & 2,42 \\
\hline & & & & 94,81 & 2,74 & 2,45 \\
\hline & & & & 95,00 & 2,58 & 2,42 \\
\hline & & & & 95,37 & 2,25 & 2,38 \\
\hline & & & & 94,63 & 2,94 & 2,43 \\
\hline & & & & 94,95 & 2,66 & 2,43 \\
\hline \multirow{3}{*}{ MARTONVÁSÁR } & \multirow{3}{*}{51,38} & \multirow{3}{*}{ 33,98 } & \multirow{3}{*}{14,65} & 50,86 & 35,40 & 13,74 \\
\hline & & & & 51,53 & 33,21 & 15,26 \\
\hline & & & & 51,74 & 33,32 & 14,94 \\
\hline
\end{tabular}


A mintaterületek 0-30 cm-es szintjének átlagolt kémiai és fizikai talajjellemző értékei a kísérletek beállítását megelőzően

\begin{tabular}{|c|c|c|c|c|c|}
\hline & Őrbottyán & Csólyospálos & Martonvásár & Nagyhörcsök & Szurdokpüspöki \\
\hline pH $\left(\mathrm{H}_{2} \mathrm{O}\right)$ & 7,5 & 8,1 & 7,3 & 8,2 & 5,6 \\
\hline Térfogat-tömeg $\left(\mathrm{g} / \mathrm{cm}^{3}\right)$ & 1,67 & 1,41 & 1,28 & 1,45 & 1,28 \\
\hline $\mathrm{CaCO}_{3}(\mathrm{~m} / \mathrm{m} \%)$ & 2,65 & 3,15 & 3,01 & 4,30 & 0,00 \\
\hline $\mathbf{A L}-\mathrm{Na}(\mathrm{mg} / \mathrm{kg})$ & 13,84 & 80,95 & - & - & - \\
\hline Humusz (\%) & 0,9 & 1,6 & 2,9 & 3,5 & 4,4 \\
\hline
\end{tabular}

A vizsgálatok Buzás (1988,1993) szerint történtek. 
Az őrbottyáni 2. mintaterület agrotechnikai bemutatása

Szerves, ill. mütrágya szükséglet: $13 / 6 / 11 \mathrm{~kg} \mathrm{~N} / \mathrm{P}_{2} \mathrm{O}_{5} / \mathrm{K}_{2} \mathrm{O}$ hatóanyag (mütrágya) / parcella

A trágyázás módja és időpontja: Kézi módszerrel, 2010, 2011, 2012 és 2013 tavaszán. A teljes NPK mennyiség egyszerre lett kijuttatva.

Kezelések (mütrágya adagok kg hatóanyag/ha):

\begin{tabular}{|c|c|c|c|c|}
\hline Parcella & Nitrogén & Foszfor & Kálium & $\begin{array}{c}\text { Öntözés a vegetációs } \\
\text { idöszakban }\end{array}$ \\
\hline $\mathbf{1 .}$ & 130 & 60 & 110 & - \\
\hline $\mathbf{2 .}$ & 0 & 0 & 0 & - \\
\hline $\mathbf{3 .}$ & 130 & 60 & 110 & + \\
\hline $\mathbf{4 .}$ & 0 & 0 & 0 & + \\
\hline $\mathbf{5 .}$ & 0 & 0 & 0 & + \\
\hline $\mathbf{6 .}$ & 130 & 60 & 110 & - \\
\hline $\mathbf{7 .}$ & 0 & 0 & 0 & - \\
\hline $\mathbf{8 .}$ & 130 & 60 & 110 & + \\
\hline
\end{tabular}




\section{A csólyospálosi mintaterületen feltárt talajszelvény leírása és jellemzői}

Feltárást készítette:

Dátum:

Földhasználat:

Kitettség:

Talajképző kőzet:

Szelvény mélysége:

Humuszos szint mélysége:

Talajtípus:
Sándor Renáta

2007.03.03.

ugar, megelőző években szántó

sík felszín

futó homok

$80 \mathrm{~cm}$

$30 \mathrm{~cm}$

Karbonátos humuszos homoktalaj

WRB: Arenosols, Cambisols

A szelvény morfológiai leírása:

\begin{tabular}{|c|c|c|}
\hline $\begin{array}{c}\text { Genetikus } \\
\text { réteg jele }\end{array}$ & $\begin{array}{l}\text { Mélység } \\
\text { cm }\end{array}$ & Szelvény leírás \\
\hline A & $0-40 \mathrm{~cm}:$ & $\begin{array}{l}\text { Szín: világosbarna, száraz. } \\
\text { Fizikai talajféleség: homok. Szerkezet: laza, szerkezet nélküli } \\
\text { homok. A feltalajban gyökér és növénymaradvány. Aranyféle } \\
\text { kötöttség: } 27 \text {; pH: } 7,4 ; \mathrm{CaCO}_{3} \text { : 4,1; humusz: } 0,9 \% \text {. } 1-6 \mathrm{~cm} \\
\text { között a humusztartalom: } 1,6 \% \text {. } \\
\text { Átmenet a következó szintbe: határozott. }\end{array}$ \\
\hline B & 40-60 cm: & $\begin{array}{l}\text { Szín: sárgás barna, száraz. Fizikai talajféleség: homok. } \\
\text { Szerkezet: szerkezet nélküli homok. Aranyféle kötöttség: } 27 \text {; } \\
\text { pH: } 7,7 ; \mathrm{CaCO}_{3}: 6,7 \% \text {, humusz: } 0,4 \% \text {. Átmenet a következő } \\
\text { szintbe: fokozatos }\end{array}$ \\
\hline $\mathrm{C}$ & 60- cm: & $\begin{array}{l}\text { Szín: fakó sárga, száraz. Fizikai talajféleség: homok. Szerkezet: } \\
\text { szerkezet nélküli homok. Aranyféle kötöttség: 26; pH: 7,9; } \\
\mathrm{CaCO}_{3}: 4,9 \% \text {, humusz: } 0,2 \text {. }\end{array}$ \\
\hline Talajvíz & $\begin{array}{l}2,1 \text { méter } \\
\text { mélységben }\end{array}$ & $\begin{array}{l}\text { pH: 8,0; sótartalom: } 0,03 \% ; \mathrm{NO}_{3}{ }^{-}:<1 \mathrm{ppm} ; \mathrm{NH}_{4}:<0,5 \mathrm{ppm} \text {; } \\
\mathrm{PO}_{4}{ }^{3-}:<0,5 \text { ppm. }\end{array}$ \\
\hline
\end{tabular}

A csólyospálosi talaj főbb tulajdonságai az 1-6 cm mélységben, 2012. május 3-án:

\begin{tabular}{|c|c|c|c|c|}
\hline Mélység & $\mathbf{p H}\left(\mathbf{H}_{\mathbf{2}} \mathbf{O}\right)$ & Térfogat-tömeg $\left(\mathbf{g} / \mathbf{c m}^{\mathbf{3}}\right)$ & $\left.\mathbf{C a C O}_{\mathbf{3}} \mathbf{( m / m} \mathbf{m}\right)$ & Humusz $(\boldsymbol{\%})$ \\
\hline $1-6 \mathrm{~cm}$ & 8,1 & 1,41 & 3,15 & 1,6 \\
\hline
\end{tabular}




\section{A martonvásári mintaterületen feltárt talajszelvény leírása és jellemzői}

A feltárást készítette:

Dátum:

Talajképző kőzet:

Kitettség:

Szelvény mélysége:

Talajvíz mélysége:

Humuszos szint mélysége:

Talajtípus:
Szücs László (Szücs, L., 1963)

1962. ősz

homokos lösz

Közel sík felszín, ÉÉK-DDNy irányban nagyon enyhén lejt

$140 \mathrm{~cm}$

$380 \mathrm{~cm}$

$85 \mathrm{~cm}$

Mészlepedékes csernozjom talaj

WRB: Chernozems

A szelvény morfológiai leírása:

\begin{tabular}{|c|c|c|}
\hline $\begin{array}{c}\text { Genetikus } \\
\text { réteg jele }\end{array}$ & $\begin{array}{c}\text { Mélység } \\
\mathbf{c m}\end{array}$ & Szelvény leírás \\
\hline $\mathrm{A}_{\mathrm{sz}}$ & $0-25 \mathrm{~cm}$ & $\begin{array}{c}\text { Szárazon barna, nedvesen csokoládés árnyalatú, sötétbarna } \\
\text { színü, poros, majd tömöttebb, nehezen szétmorzsolható rögös } \\
\text { szemcsés vályog. A feltalaj hajszálgyökerekkel gazdagon } \\
\text { átszött. Átmenet éles. pH: 6,8. }\end{array}$ \\
\hline $\mathrm{A}_{\mathrm{et}}$ & $25-32 \mathrm{~cm}$ & $\begin{array}{c}\text { Szürkésfekete-csokoládés árnyalatú, száraz, tömödött, } \\
\text { poliéderes törésü rögös vályog. Hajszálgyökerek találhatók } \\
\text { benne. }\end{array}$ \\
\hline $\mathrm{B}_{1}$ & $32-70 \mathrm{~cm}$ & $\begin{array}{c}\text { Feketebarna, kissé csokoládés árnyalatú (márványozott) nyirkos, } \\
\text { nyomásra apró szemcsékre széthulló vályog. Hajszálgyökerek } \\
\text { találhatók benne. Függőlegesen repedezett. 70 cm-töl láthatók } \\
\text { mészpettyek. Az átmenet fokozatos. pH: 7,9. Pezsgés 45 cm-töl. }\end{array}$ \\
\hline $\mathrm{B}_{2}$ & $70-85 \mathrm{~cm}$ & $\begin{array}{c}\text { Az elöbbihez hasonló, de erösebben mészpettyes szint. Átmenet } \\
\text { éles. }\end{array}$ \\
\hline $\mathrm{BC}$ & $85-95 \mathrm{~cm}$ & $\begin{array}{r}\text { Szürkéssárga, barna humuszos foltokkal tarkított homokos } \\
\text { vályog. Mészpettyes. Átmenet éles. pH: 8,0. }\end{array}$ \\
\hline $\mathrm{C}$ & $95-130 \mathrm{~cm}$ & $\begin{array}{r}\text { Világossárga, apró fehér foltos homokos lösz. Elszórtan } \\
\text { mészkonkréciós. }\end{array}$ \\
\hline & $130-\mathrm{cm}$ & $\begin{array}{r}\text { Világosszürke-fehéressárga löszös homok. Szürke foltos, a } \\
\text { foltok külsö kerülete körül rozsdás. Az egész szelvény eléggé } \\
\text { kiszáradt állapotú. pH: 8,5. }\end{array}$ \\
\hline
\end{tabular}




\section{A nagyhörcsöki mintaterületen feltárt talajszelvény leírása és jellemzői}

A feltárást készítette: $\quad$ Várallyay György (Várallyay et al., 2009)

Dátum:

2005. nyár

Földhasználat:

gyep

Kitettség:

Sík felszín

Talajképző kőzet:

lösz

Szelvény mélysége:

$120 \mathrm{~cm}$

Humuszos szint mélysége:

Talajtípus:

Mészlepedékes csernozjom talaj

WRB: Chernozems

A szelvény morfológiai leírása:

\begin{tabular}{|c|c|c|}
\hline $\begin{array}{l}\text { Genetikus } \\
\text { réteg jele }\end{array}$ & $\begin{array}{c}\text { Mélység } \\
\text { cm }\end{array}$ & Szelvény leírás \\
\hline A & $0-35 \mathrm{~cm}$ & $\begin{array}{l}\text { Szín: sötétbarna, száraz. Fizikai talajféleség: vályog. } \\
\text { Szerkezet: morzsás, közepesen tömödött. Sok kicsi pórus, } \\
\text { gyökér és növénymaradvány. pH: } 8,2 ; \mathrm{CaCO}_{3}: 4,3 ; \text { humusz: } 3,5 \text {. } \\
\text { Âtmenet a következő szintbe: fokozatos. }\end{array}$ \\
\hline B & $35-65 \mathrm{~cm}$ & $\begin{array}{l}\text { Szín: barna, száraz. Fizikai talajféleség: vályog. Szerkezet: } \\
\text { morzsás. Gilisztajárotok. Kiválás: mészlepedék. pH: 8,4; } \\
\mathrm{CaCO}_{3}: 16,1 \% \text {, humusz: 2,3. Átmenet a következő szintbe: } \\
\text { fokozatos }\end{array}$ \\
\hline $\mathrm{BC}_{\mathrm{k}}$ & $65-110 \mathrm{~cm}$ & $\begin{array}{l}\text { Szín: sárgásbarna, száraz. Fizikai talajféleség: homokos agyagos } \\
\text { vályog. Gyengén szerkezetes. Laza. Kiválások: mészlepedék. } \\
\text { mészerek. pH: } 8,6 ; \mathrm{CaCO}_{3}: 23,0 \% \text {, humusz: 1,4. Átmenet a } \\
\text { következő szintbe: fokozatos. }\end{array}$ \\
\hline $\mathrm{C}_{\mathrm{k}}$ & $110-\mathrm{cm}$ & $\begin{array}{l}\text { Szín: fakó sárga, száraz. Fizikai talajféleség: homokos agyago } \\
\text { vályog. Szerkezet nélküli. Laza. Kiválások: mészfoltok } \\
\text { mészerek. pH: } 8,7 ; \mathrm{CaCO}_{3}: 26,4 \% \text {, humusz: } 1,4 .\end{array}$ \\
\hline
\end{tabular}




\section{A szurdokpüspöki mintaterületen feltárt talajszelvény leírása és jellemzői}

A feltárást készítette:

Dátum:

Földhasználat:

Kitettség:

Talajképző kőzet:

Szelvény mélysége:

Humuszos szint mélysége:

Talajtípus:
Koós Sándor

2004.04.15.

erdő

közel sík felszín, enyhe DNY-i lejtés

andezit és andezit tufa

$100 \mathrm{~cm}$

$35 \mathrm{~cm}$

erdőtalaj

WRB: Haplic Vertisols

A szelvény morfológiai leírása:

\begin{tabular}{|c|c|l|}
\hline $\begin{array}{c}\text { Genetikus réteg } \\
\text { jele }\end{array}$ & $\begin{array}{c}\text { Mélység } \\
\text { cm }\end{array}$ & \multicolumn{1}{|c|}{ Szelvény leírás } \\
\hline $\mathrm{A}_{00}$ & $0-5$ & $\begin{array}{l}\text { Alig elbomlott növényi maradványok (friss avar), } \\
\text { amelyben a növényi szerkezet jól felismerhetö. Átmenet } \\
\text { a következö szintbe hullámos. }\end{array}$ \\
\hline $\mathrm{A}_{0}{ }^{\mathrm{T}}$ & $5-10$ & $\begin{array}{l}\text { Sötét barna, félig elbomlott növényi maradványok } \\
\text { (alomtakaró). Átmenet a következö szintbe éles. }\end{array}$ \\
\hline $\mathrm{A}_{1}$ & $0-15$ & $\begin{array}{l}\text { Sötét barna, nedves. Fizikai talajféleség: agyag. } \\
\text { Közepesen szerkezetes, szemcsés. Gyökerekkel sủrün } \\
\text { átszött, enyhén tömödött. Sok gilisztajárat. Átmenet a } \\
\text { következö szintbe fokozatos. }\end{array}$ \\
\hline $\mathrm{A}_{2}$ & $15-25$ & $\begin{array}{l}\text { Sötét sárgásbarna, nyirkos. Fizikai talajféleség: agyag. } \\
\text { Erösen szerkezetes, poliéderes. Gyökerekkel átszött, } \\
\text { közepesen tömödött. Átmenete a felhalmozódási szintbe } \\
\text { hullámos. }\end{array}$ \\
\hline $\mathrm{B}_{1}$ & $25-40$ & $\begin{array}{l}\text { Sötét barna, nedves. Fizikai talajféleség: agyag. } \\
\text { Gyengén szerkezetes, hasábos szerkezetü. Gyökerekkel } \\
\text { átszött, közepesen tömödött. Átmenet a következö } \\
\text { szintbe elmosódott. }\end{array}$ \\
\hline $\mathrm{B}_{2}$ & $40-100$ & $\begin{array}{l}\text { Sötét barna, sáros. Fizikai talajféleség: agyag. Hasábos } \\
\text { szerkezetü. Gyökerekkel átszőtt, közepesen tömödött. } \\
\text { Átmenet a következö szintbe éles. }\end{array}$ \\
\hline $\mathrm{C}$ & $100-$ & \begin{tabular}{l} 
Andezit és andezit tufa \\
\hline
\end{tabular} \\
\hline
\end{tabular}


A léptékfüggés megjelenése a meteorológiai adatsorok felhasználásakor c. fejezet bemenő adatai és paraméterei

Modell: 4Mx

Modell felbontás: dm-es

Modellezett időszak: 2010.04.25. és 2010.06.02 - 2010.06.14

Helyszín: Őrbottyán

Szimulált szelvény mélysége: $170 \mathrm{~cm}$

\begin{tabular}{|c|c|c|c|c|}
\hline Adat típusa & Adat megnevezése & $\begin{array}{l}\text { Mérési } \\
\text { hely }\end{array}$ & Felbontás & Felhasználás \\
\hline \multirow{4}{*}{ Meteorológiai } & Globálsugárzás $\left[\mathrm{MJ} / \mathrm{m}^{2}\right]$ & mintaterület & napi & \multirow{4}{*}{$\begin{array}{c}\text { A 4Mx } \\
\text { futtatásakor } \\
\text { bemenő időjárási } \\
\text { adatok }\end{array}$} \\
\hline & $\begin{array}{l}\text { Maximális hőmérséklet } \\
{\left[{ }^{\circ} \mathrm{C}\right]}\end{array}$ & mintaterület & napi és 5 perces & \\
\hline & $\begin{array}{l}\text { Minimális hőmérséklet } \\
{\left[{ }^{\circ} \mathrm{C}\right]}\end{array}$ & mintaterület & napi és 5 perces & \\
\hline & Csapadék [mm] & mintaterület & napi & \\
\hline \multirow{8}{*}{ Talajtani } & Albedó [] & $\begin{array}{l}\text { számított } \\
\text { értékek }\end{array}$ & napi & \multirow{8}{*}{$\begin{array}{l}\text { Talajfizikai input } \\
\text { file }\end{array}$} \\
\hline & $\begin{array}{l}\text { Maximális tócsamélység } \\
{[\mathrm{mm}]}\end{array}$ & $\begin{array}{l}\text { számított } \\
\text { értékek }\end{array}$ & - & \\
\hline & Térfogattömeg $\left[\mathrm{g} / \mathrm{cm}^{3}\right]$ & mintaterület & $\begin{array}{l}5 \text { mérési } \\
\text { pontban }\end{array}$ & \\
\hline & $\Theta_{\max }[-]$ & mintaterület & $\begin{array}{l}5 \text { mérési } \\
\text { pontban }\end{array}$ & \\
\hline & $\Theta_{\mathrm{fc}}[-]$ & mintaterület & $\begin{array}{l}5 \text { mérési } \\
\text { pontban }\end{array}$ & \\
\hline & $\Theta_{w p}[-]$ & mintaterület & $\begin{array}{l}5 \text { mérési } \\
\text { pontban }\end{array}$ & \\
\hline & Drénhányad [0-1] & $\begin{array}{l}\text { számított } \\
\text { érték }\end{array}$ & 0,4 & \\
\hline & $\mathrm{K}_{\mathrm{S}}[\mathrm{cm} / \mathrm{nap}]$ & mintaterület & $\begin{array}{l}5 \text { mérési } \\
\text { pontban }\end{array}$ & \\
\hline Növényi & kukorica & mintaterület & napi & Növényi input file \\
\hline
\end{tabular}


Eltérō térléptékű modellekkel számított talajhőmérséklet értékek összehasonlítása c.

fejezet HYDRUS-1D bemenő adatai és paraméterei

Modell: HYDRUS-1D

Modell felbontás: cm-es

Alkalmazott hidrológiai modell beállítás: van Genuchten - Mualem

Modellezett időszak: 2010.03.31. - 2011.09.30.

Helyszín: Örbottyán, 2. mintaterület, 1. parcella

Szimulált szelvény mélysége: $171 \mathrm{~cm}$

Szimulált növény: kukorica

\begin{tabular}{|c|c|c|c|c|}
\hline Adat típusa & Adat megnevezése & Mérési hely & Felbontás & Felhasználás \\
\hline \multirow{5}{*}{ Meteorológiai } & $\begin{array}{c}\text { Globálsugárzás } \\
{\left[\mathrm{MJ} / \mathrm{m}^{2}\right]}\end{array}$ & mintaterület & $\begin{array}{c}\text { napi (5 percesből } \\
\text { átlagolva) }\end{array}$ & \multirow{6}{*}{$\begin{array}{l}\text { A HYDRUS-1D } \\
\text { futtatásakor } \\
\text { bemenő adatok }\end{array}$} \\
\hline & $\begin{array}{c}\text { Maximális } \\
\text { hőmérséklet }\left[{ }^{\circ} \mathrm{C}\right]\end{array}$ & mintaterület & napi & \\
\hline & $\begin{array}{c}\text { Minimális } \\
\text { hőmérséklet }\left[{ }^{\circ} \mathrm{C}\right]\end{array}$ & mintaterület & napi & \\
\hline & Csapadék [mm] & mintaterület & $\begin{array}{l}\text { napi ( } 5 \text { percesből } \\
\text { átlagolva) }\end{array}$ & \\
\hline & szélsebesség $\left[\mathrm{ms}^{-1}\right]$ & mintaterület & $\begin{array}{c}\text { napi (5 percesből } \\
\text { átlagolva) }\end{array}$ & \\
\hline \multirow{6}{*}{ Talajtani } & Albedó [-] & $\begin{array}{l}\text { számított } \\
\text { értékek }\end{array}$ & napi & \\
\hline & $\Theta_{\mathrm{wp}}[-]$ & mintaterület & 5 mérési pontban & \multirow{5}{*}{$\begin{array}{l}\text { Talajfizikai input } \\
\text { file }\end{array}$} \\
\hline & $\Theta_{\max }[-]$ & mintaterület & 5 mérési pontban & \\
\hline & $\alpha[1 / \mathrm{cm}]$ & \begin{tabular}{|c|} 
mintaterületen \\
mért $\mathrm{pF}$ \\
értékekből \\
számítva \\
\end{tabular} & $\begin{array}{c}5 \text { mérési pontban, } 5 \text { - } \\
10, \mathrm{~cm}-\mathrm{es} \\
\text { mélységben }\end{array}$ & \\
\hline & $\mathrm{n}[-]$ & \begin{tabular}{|c|} 
mintaterületen \\
mért $\mathrm{pF}$ \\
értékekből \\
számítva \\
\end{tabular} & $\begin{array}{c}5 \text { mérési pontban, } 5 \text { - } \\
10, \mathrm{~cm}-\mathrm{es} \\
\text { mélységekben }\end{array}$ & \\
\hline & $\mathrm{KS}$ [cm/nap] & mintaterület & 5 mérési pontban & \\
\hline \multirow{3}{*}{ Növényi } & LAI [-] & mintaterület & napi & \multirow{3}{*}{$\begin{array}{c}\text { A modell } \\
\text { kalibrálásához } \\
\text { használt } 4 \mathrm{Mx} \\
\text { adatok }\end{array}$} \\
\hline & $\begin{array}{c}\text { növény magasság } \\
{[\mathrm{cm}]}\end{array}$ & mintaterület & napi & \\
\hline & $\begin{array}{l}\text { gyökerezési mélység } \\
{[\mathrm{cm}]}\end{array}$ & mintaterület & napi & \\
\hline
\end{tabular}


Eltérő térléptékü modellekkel számított talajhőmérséklet értékek összehasonlítása c. fejezet $4 M x$ és módosított $4 M x$ bemenő adatai és paraméterei

Modell: 4Mx

Modell felbontás: dm-es

Modellezett időszak: 2010.03.31. - 2011.09.30.

Helyszín: Örbottyán, 2. mintaterület, 1. parcella

Szimulált szelvény mélysége: $170 \mathrm{~cm}$

Szimulált növény: kukorica

Módosított 4Mx esetében c $=4$, eredeti 4Mx esetében $\mathrm{c}=0$.

\begin{tabular}{|c|c|c|c|c|}
\hline Adat típusa & Adat megnevezése & $\begin{array}{c}\text { Mérési } \\
\text { hely }\end{array}$ & Felbontás & Felhasználás \\
\hline \multirow{4}{*}{ Meteorológiai } & Globálsugárzás $\left[\mathrm{MJ} / \mathrm{m}^{2}\right]$ & mintaterület & $\begin{array}{c}\text { napi (5 } \\
\text { percesből } \\
\text { átlagolva) } \\
\end{array}$ & \multirow{4}{*}{$\begin{array}{c}\text { A 4Mx } \\
\text { futtatásakor } \\
\text { bemenő időjárási } \\
\text { adatok }\end{array}$} \\
\hline & $\begin{array}{l}\text { Maximális hőmérséklet } \\
{\left[{ }^{\circ} \mathrm{C}\right]}\end{array}$ & mintaterület & napi & \\
\hline & $\begin{array}{c}\text { Minimális hőmérséklet } \\
{\left[{ }^{\circ} \mathrm{C}\right]}\end{array}$ & mintaterület & napi & \\
\hline & Csapadék [mm] & mintaterület & $\begin{array}{c}\text { napi (5 } \\
\text { percesbö1 } \\
\text { átlagolva) }\end{array}$ & \\
\hline \multirow{8}{*}{ Talajtani } & Albedó [] & $\begin{array}{l}\text { számított } \\
\text { értékek }\end{array}$ & napi & \multirow{8}{*}{$\begin{array}{l}\text { Talajfizikai input } \\
\text { file }\end{array}$} \\
\hline & $\begin{array}{c}\text { Maximális tócsamélység } \\
{[\mathrm{mm}]}\end{array}$ & $\begin{array}{c}\text { számított } \\
\text { értékek }\end{array}$ & - & \\
\hline & Térfogattömeg $\left[\mathrm{g} / \mathrm{cm}^{3}\right]$ & mintaterület & $\begin{array}{l}5 \text { mérési } \\
\text { pontban }\end{array}$ & \\
\hline & $\Theta_{\max }[-]$ & mintaterület & $\begin{array}{l}5 \text { mérési } \\
\text { pontban }\end{array}$ & \\
\hline & $\Theta_{\mathrm{fc}}[-]$ & mintaterület & $\begin{array}{l}5 \text { mérési } \\
\text { pontban }\end{array}$ & \\
\hline & $\Theta_{w p}[-]$ & mintaterület & $\begin{array}{l}5 \text { mérési } \\
\text { pontban }\end{array}$ & \\
\hline & Drénhányad [0-1] & $\begin{array}{l}\text { számított } \\
\text { érték }\end{array}$ & 0,4 & \\
\hline & $\mathrm{K}_{\mathrm{S}}[\mathrm{cm} / \mathrm{nap}]$ & mintaterület & $\begin{array}{l}5 \text { mérési } \\
\text { pontban }\end{array}$ & \\
\hline \multirow{3}{*}{ Növényi } & LAI [-] & mintaterület & napi & \multirow{3}{*}{$\begin{array}{l}\text { HYDRUS-1D } \\
\text { kalibrálása inverz } \\
\text { módszerrel }\end{array}$} \\
\hline & növény magasság [cm] & mintaterület & napi & \\
\hline & $\begin{array}{l}\text { gyökerezési mélység } \\
{[\mathrm{cm}]}\end{array}$ & mintaterület & napi & \\
\hline
\end{tabular}


Mért és szimulált talajnedvesség értékek összehasonlítása, növénytermesztési kísérlet kezelésében c. fejezet bemenő adatai és paraméterei

Modell: HYDRUS-1D

Modell felbontás: cm-es és dm-es

Alkalmazott hidrológiai modell beállítás: van Genuchten - Mualem

Modellezett időszak: 2010.03.31. -2013.04.18.

Helyszín: Örbottyán, 2. mintaterület

Szimulált szelvény mélysége: $171 \mathrm{~cm}$

Szimulált talajszintek: 0-30, 30-60, 60-90, 90-171 cm

Szimulált növény: kukorica

\begin{tabular}{|c|c|c|c|c|}
\hline Adat típusa & Adat megnevezése & Mérési hely & Felbontás & Felhasználás \\
\hline \multirow{5}{*}{ Meteorológiai } & $\begin{array}{c}\text { Globálsugárzás } \\
{\left[\mathrm{MJ} / \mathrm{m}^{2}\right]}\end{array}$ & mintaterület & $\begin{array}{c}\text { napi (5 percesből } \\
\text { átlagolva) }\end{array}$ & \multirow{6}{*}{$\begin{array}{l}\text { A HYDRUS-1D } \\
\text { futtatásakor } \\
\text { bemenő adatok }\end{array}$} \\
\hline & $\begin{array}{c}\text { Maximális } \\
\text { hömérséklet }\left[{ }^{\circ} \mathrm{C}\right]\end{array}$ & mintaterület & napi & \\
\hline & $\begin{array}{c}\text { Minimális } \\
\text { hőmérséklet }\left[{ }^{\circ} \mathrm{C}\right]\end{array}$ & mintaterület & napi & \\
\hline & Csapadék [mm] & mintaterület & $\begin{array}{l}\text { napi ( } 5 \text { percesből } \\
\text { átlagolva) }\end{array}$ & \\
\hline & szélsebesség $\left[\mathrm{ms}^{-1}\right]$ & mintaterület & $\begin{array}{l}\text { napi (5 percesböl } \\
\text { átlagolva) }\end{array}$ & \\
\hline \multirow{6}{*}{ Talajtani } & Albedó [-] & $\begin{array}{l}\text { számított } \\
\text { értékek }\end{array}$ & napi & \\
\hline & $\Theta_{w p}[-]$ & mintaterület & 3 mélységben & \multirow{5}{*}{$\begin{array}{l}\text { Talajfizikai input } \\
\text { file }\end{array}$} \\
\hline & $\Theta_{\max }[-]$ & mintaterület & 3 mélységben & \\
\hline & $\alpha[1 / \mathrm{cm}]$ & $\begin{array}{l}\text { mintaterületen } \\
\text { mért pF } \\
\text { értékekből } \\
\text { számítva }\end{array}$ & $\begin{array}{l}2 \text { mérési pontban, 5- } \\
10,35-40 \text { és } 65-70 \\
\text { cm-es mélységekben }\end{array}$ & \\
\hline & $\mathrm{n}[-]$ & $\begin{array}{c}\text { mintaterületen } \\
\text { mért pF } \\
\text { értékekből } \\
\text { számítva }\end{array}$ & $\begin{array}{l}2 \text { mérési pontban, 5- } \\
\text { 10, 35-40 és } 65-70 \\
\text { cm-es mélységekben }\end{array}$ & \\
\hline & $\mathrm{K}_{\mathrm{S}}[\mathrm{cm} / \mathrm{nap}]$ & mintaterület & $\begin{array}{l}3 \text { mérési pontban, 5- } \\
\text { 10, 35-40 és } 65-70 \\
\text { cm-es mélységekben }\end{array}$ & \\
\hline \multirow{3}{*}{ Növényi } & LAI [-] & mintaterület & napi & \multirow{3}{*}{$\begin{array}{l}\text { A modell } \\
\text { kalibrálása }\end{array}$} \\
\hline & $\begin{array}{c}\text { növény magasság } \\
{[\mathrm{cm}]}\end{array}$ & mintaterület & napi & \\
\hline & $\begin{array}{l}\text { gyökerezési mélység } \\
{[\mathrm{cm}]}\end{array}$ & mintaterület & napi & \\
\hline
\end{tabular}


Beszivárgás és talajpárolgás modellezésének térbeli léptékfüggése c. fejezet bemenő adatai és paraméterei

Modell: 4Mx

Modell felbontás: dm-es és cm-es

Modellezett időszak: 2012.06.01. - 2012.07.07.

Helyszín: Örbottyán, 2. mintaterület

Szimulált szelvény mélysége: $170 \mathrm{~cm}$

Szimulált földhasználat: ugar

\begin{tabular}{|c|c|c|c|c|}
\hline Adat típusa & Adat megnevezése & $\begin{array}{c}\text { Mérési } \\
\text { hely }\end{array}$ & Felbontás & Felhasználás \\
\hline \multirow{4}{*}{ Meteorológiai } & Globálsugárzás $\left[\mathrm{MJ} / \mathrm{m}^{2}\right]$ & mintaterület & $\begin{array}{c}\text { napi (5 } \\
\text { percesből } \\
\text { átlagolva) }\end{array}$ & \multirow{4}{*}{$\begin{array}{c}\text { A 4Mx } \\
\text { futtatásakor } \\
\text { bemenő időjárási } \\
\text { adatok }\end{array}$} \\
\hline & $\begin{array}{l}\text { Maximális hőmérséklet } \\
{\left[{ }^{\circ} \mathrm{C}\right]}\end{array}$ & mintaterület & napi & \\
\hline & $\begin{array}{l}\text { Minimális hőmérséklet } \\
{\left[{ }^{\circ} \mathrm{C}\right]}\end{array}$ & mintaterület & napi & \\
\hline & Csapadék [mm] & mintaterület & $\begin{array}{c}\text { napi (5 } \\
\text { percesböl } \\
\text { átlagolva) } \\
\end{array}$ & \\
\hline \multirow{8}{*}{ Talajtani } & Albedó [] & $\begin{array}{l}\text { számított } \\
\text { értékek }\end{array}$ & napi & \multirow{8}{*}{$\begin{array}{l}\text { Talajfizikai input } \\
\text { file }\end{array}$} \\
\hline & $\begin{array}{c}\text { Maximális tócsamélység } \\
{[\mathrm{mm}]}\end{array}$ & $\begin{array}{l}\text { számított } \\
\text { értékek }\end{array}$ & - & \\
\hline & Térfogattömeg $\left[\mathrm{g} / \mathrm{cm}^{3}\right]$ & mintaterület & $\begin{array}{l}5 \text { mérési } \\
\text { pontban }\end{array}$ & \\
\hline & $\Theta_{\max }[-]$ & mintaterület & $\begin{array}{l}5 \text { mérési } \\
\text { pontban }\end{array}$ & \\
\hline & $\Theta_{\mathrm{fc}}[-]$ & mintaterület & $\begin{array}{l}5 \text { mérési } \\
\text { pontban }\end{array}$ & \\
\hline & $\Theta_{w p}[-]$ & mintaterület & $\begin{array}{l}5 \text { mérési } \\
\text { pontban }\end{array}$ & \\
\hline & Drénhányad [0-1] & $\begin{array}{l}\text { számított } \\
\text { érték }\end{array}$ & 0,4 & \\
\hline & $\mathrm{K}_{\mathrm{S}}[\mathrm{cm} / \mathrm{nap}]$ & mintaterület & $\begin{array}{c}5 \text { mérési } \\
\text { pontban } \\
\text { TDI-vel mérve }\end{array}$ & \\
\hline Növényi & ugar & mintaterület & - & $\begin{array}{c}\text { ugar felszínt } \\
\text { használtunk a } \\
\text { szimulációhoz, } \\
\text { növényi adatokat } \\
\text { nem adtunk meg }\end{array}$ \\
\hline
\end{tabular}


7.4.1. A térbeli heterogenitás következtében előálló modellezési problémák, különböző szimulációs technikák esetén c. fejezet bemenő adatai

$\mathrm{K}_{\mathrm{S}}$ mérési módszer: Guelph permeaméter

$\mathrm{K}_{\mathrm{S}}$ mérési mélység: $15 \mathrm{~cm}$

$\mathrm{K}_{\mathrm{S}}$ mérési időpont: 2009. ősz.

$\mathrm{K}_{\mathrm{S}}$ mérési helyszín: Örbottyán

\begin{tabular}{|c|c|}
\hline $\mathbf{K}_{\mathbf{S}}[\mathbf{c m} / \mathbf{n a p}]$ & $\mathbf{K}_{\mathbf{S}}$ átlag $[\mathbf{c m} / \mathbf{n a p}]$ \\
\hline 112,8 & \\
\hline 113,3 & \\
\hline 30,1 & 89,9 \\
\hline 94,9 & \\
\hline 97,9 & \\
\hline
\end{tabular}

HYDRUS-1D-vel modellezett csapadékintenzitások:

\begin{tabular}{|c|c|c|}
\hline Csapadék [mm] & Idő [perc] & Intenzitás [mm/sec] \\
\hline 15 & 20 & 0,0125 \\
\hline 30 & 20 & 0,025 \\
\hline 72 & 30 & 0,04 \\
\hline 90 & 30 & 0,05 \\
\hline
\end{tabular}

HYDRUS-1D modell beállítások:

Modell felbontás: cm-es

Szimulált szelvény mélysége: $100 \mathrm{~cm}$

Szelvény felépítése: 1 anyag: homok

Modellezett időegység: 1440 perc

Alkalmazott hidrológiai modell beállítás: van Genuchten - Mualem

Qs: 0,404

Alpha: 0,01615 1/cm

$\mathrm{n}=1,682$ 
A csólyospálosi mintaterületen mért csapadék mennyisége 2011.július 24. és 2011.

október 14. között

\begin{tabular}{|c|c|c|}
\hline $\begin{array}{c}\text { Dátum } \\
\text { [ééé.hh.nn] }\end{array}$ & $\begin{array}{c}\text { Csapadék } \\
{[\mathrm{mm}]}\end{array}$ & $\begin{array}{c}\text { Kumulált } \\
\text { csapadék } \\
{[\mathrm{mm}]}\end{array}$ \\
\hline 2011.07 .25 & 9 & 9 \\
\hline 2011.07 .26 & 16 & 25 \\
\hline 2011.07 .28 & 2 & 27 \\
\hline 2011.07 .30 & 10 & 37 \\
\hline 2011.08 .02 & 1 & 38 \\
\hline 2011.08 .09 & 6 & 44 \\
\hline 2011.09 .20 & 5 & 49 \\
\hline 2011.10 .07 & 5 & 54 \\
\hline 2011.10 .10 & 3 & 57 \\
\hline 2011.10 .20 & 1 & 58 \\
\hline 2011.10 .21 & 8 & 66 \\
\hline
\end{tabular}


Az őrbottyáni mintaterületen mért csapadék mennyisége 2011. április 18. és 2011. augusztus 9. között

\begin{tabular}{|c|c|c|}
\hline $\begin{array}{c}\text { Dátum } \\
\text { [ééé.hh.nn] }\end{array}$ & $\begin{array}{c}\text { Csapadék } \\
{[\mathrm{mm}]}\end{array}$ & $\begin{array}{c}\text { Kumulált } \\
\text { csapadék } \\
\text { [mm] }\end{array}$ \\
\hline 2011.04 .25 & 7,2 & 7,2 \\
\hline 2011.04 .27 & 0,4 & 7,6 \\
\hline 2011.04 .30 & 3,2 & 10,8 \\
\hline 2011.05 .01 & 4 & 14,8 \\
\hline 2011.05 .07 & 0,4 & 15,2 \\
\hline 2011.05 .08 & 5,2 & 20,4 \\
\hline 2011.05 .12 & 20 & 40,4 \\
\hline 2011.05 .13 & 1,2 & 41,6 \\
\hline 2011.05 .15 & 3,2 & 44,8 \\
\hline 2011.05 .16 & 20 & 64,8 \\
\hline 2011.05 .20 & 0,8 & 65,6 \\
\hline 2011.05 .27 & 2,8 & 68,4 \\
\hline 2011.05 .30 & 7,6 & 76 \\
\hline 2011.05 .31 & 0,4 & 76,4 \\
\hline 2011.06 .01 & 6,4 & 82,8 \\
\hline 2011.06 .05 & 2 & 84,8 \\
\hline 2011.06 .06 & 19,2 & 104 \\
\hline 2011.06 .07 & 3,2 & 107,2 \\
\hline 2011.06 .08 & 7,6 & 114,8 \\
\hline 2011.06 .09 & 0,4 & 115,2 \\
\hline 2011.06 .10 & 11,6 & 126,8 \\
\hline 2011.06 .14 & 16,8 & 143,6 \\
\hline 2011.06 .23 & 6,8 & 150,4 \\
\hline 2011.06 .24 & 1,6 & 152 \\
\hline 2011.06 .29 & 0,8 & 152,8 \\
\hline 2011.06 .30 & 20 & 172,8 \\
\hline 2011.07 .01 & 0,4 & 173,2 \\
\hline 2011.07 .02 & 0,8 & 174 \\
\hline 2011.07 .03 & 1,2 & 175,2 \\
\hline 2011.07 .10 & 0,8 & 176 \\
\hline 2011.07 .15 & 0,8 & 176,8 \\
\hline 2011.07 .18 & 2,8 & 179,6 \\
\hline 2011.07 .19 & 12,8 & 192,4 \\
\hline
\end{tabular}

\begin{tabular}{|c|c|c|}
\hline 2011.07 .20 & 45,6 & 238 \\
\hline 2011.07 .21 & 6,8 & 244,8 \\
\hline 2011.07 .22 & 1,6 & 246,4 \\
\hline 2011.07 .23 & 2 & 248,4 \\
\hline 2011.07 .24 & 16 & 264,4 \\
\hline 2011.07 .25 & 2,8 & 267,2 \\
\hline 2011.07 .26 & 0,4 & 267,6 \\
\hline 2011.07 .27 & 19,2 & 286,8 \\
\hline 2011.07 .28 & 8,8 & 295,6 \\
\hline 2011.07 .29 & 0,4 & 296 \\
\hline 2011.07 .30 & 0,4 & 296,4 \\
\hline 2011.07 .31 & 2 & 298,4 \\
\hline 2011.08 .03 & 0,4 & 298,8 \\
\hline 2011.08 .05 & 2,8 & 301,6 \\
\hline 2011.08 .08 & 6 & 307,6 \\
\hline
\end{tabular}


A martonvásári mintaterületen mért csapadék mennyisége 2011. június 7. és 2011.

szeptember 22. között

\begin{tabular}{|c|c|c|}
\hline $\begin{array}{c}\text { Dátum } \\
\text { [ééé.hh.nn] }\end{array}$ & $\begin{array}{c}\text { Csapadék } \\
\text { [mm] }\end{array}$ & $\begin{array}{c}\text { Kumulált } \\
\text { csapadék } \\
\text { [mm] }\end{array}$ \\
\hline 2011.06 .08 & 1,2 & 1,2 \\
\hline 2011.06 .14 & 0,1 & 1,3 \\
\hline 2011.06 .23 & 11,4 & 12,7 \\
\hline 2011.06 .24 & 2,3 & 15,0 \\
\hline 2011.06 .29 & 1,3 & 16,3 \\
\hline 2011.06 .30 & 21,4 & 37,7 \\
\hline 2011.07 .01 & 1,1 & 38,8 \\
\hline 2011.07 .03 & 2,1 & 40,9 \\
\hline 2011.07 .18 & 1,3 & 42,2 \\
\hline 2011.07 .19 & 12,1 & 54,3 \\
\hline 2011.07 .20 & 16,8 & 71,1 \\
\hline 2011.07 .21 & 9,9 & 81,0 \\
\hline 2011.07 .22 & 0,5 & 81,5 \\
\hline 2011.07 .23 & 1,5 & 83,0 \\
\hline 2011.07 .24 & 5,5 & 88,5 \\
\hline 2011.07 .25 & 2,2 & 90,7 \\
\hline 2011.07 .28 & 3,4 & 94,1 \\
\hline 2011.07 .30 & 0,3 & 94,4 \\
\hline 2011.08 .04 & 3,8 & 98,2 \\
\hline 2011.08 .08 & 0,9 & 99,1 \\
\hline 2011.08 .15 & 0,8 & 99,9 \\
\hline 2011.09 .01 & 0,3 & 100,2 \\
\hline 2011.09 .08 & 0,8 & 101,0 \\
\hline 2011.09 .19 & 10,3 & 111,3 \\
\hline 2011.09 .20 & 0,6 & 111,9 \\
\hline
\end{tabular}


A talajok víztaszítás értékének térbeli változatossága Csólyospálos mintaterületén, 2012. május 3-án és Őrbottyánban 2012. május 31-én, Dekker és Ritsema (1996) alapján

Csólyospálos:

\begin{tabular}{|c|c|c|c|c|c|c|c|c|c|c|}
\hline $\begin{array}{l}\text { WDPT } \\
\text { [sec] }\end{array}$ & 1 & 2 & 3 & 4 & 5 & 6 & 7 & 8 & 9 & 10 \\
\hline $\mathbf{J}$ & 689 & 1605 & 2235 & 123 & 115 & 6 & 19 & 13 & 5 & 35 \\
\hline I & 512 & 144 & 36 & 698 & 40 & 77 & 46 & 32 & 313 & 192 \\
\hline H & 672 & 146 & 38 & 24 & 121 & 1194 & 473 & 17 & 312 & 149 \\
\hline G & 138 & 284 & 160 & 12 & 35 & 114 & 283 & 570 & 105 & 43 \\
\hline $\mathbf{F}$ & 271 & 45 & 28 & 23 & 65 & 24 & 100 & 148 & 89 & 35 \\
\hline$E$ & 47 & 294 & 503 & 187 & 218 & 112 & 97 & 32 & 825 & 83 \\
\hline D & 135 & 63 & 12 & 55 & 58 & 19 & 41 & 102 & 4 & 24 \\
\hline C & 80 & 55 & 3 & 65 & 53 & 135 & 388 & 230 & 769 & 194 \\
\hline B & 61 & 137 & 70 & 94 & 16 & 54 & 25 & 261 & 208 & 182 \\
\hline A & 395 & 294 & 37 & 432 & 43 & 224 & 91 & 108 & 36 & 41 \\
\hline & $\begin{array}{l}\text { nedvesíthe } \\
\text { gyengén ví } \\
\text { víztaszító }\end{array}$ & $\begin{array}{l}3[<5 \mathrm{~s}] \\
\text { taszító } \\
0-600 \mathrm{~s}\end{array}$ & 5-60 s] & & ottyá & $\begin{array}{l}\text { rősen } \\
\text { xtrém } \\
\text { : }\end{array}$ & $\begin{array}{l}\text { ztaszít } \\
\text { ztaszít }\end{array}$ & $\begin{array}{l}{[600-3} \\
>3600\end{array}$ & & \\
\hline $\begin{array}{l}\text { WDPT } \\
\text { [sec] }\end{array}$ & 1 & 2 & 3 & 4 & 5 & 6 & 7 & 8 & 9 & 10 \\
\hline $\mathbf{J}$ & 0 & 1 & 0 & 0 & 0 & 0 & 0 & 0 & 10 & 0 \\
\hline I & 0 & 0 & 0 & 1 & 0 & 0 & 0 & 0 & 0 & 16 \\
\hline H & 2 & 2 & 1 & 0 & 7 & 21 & 0 & 0 & 2 & 1 \\
\hline G & 0 & 0 & 0 & 1 & 0 & 0 & 2 & 0 & 3 & 1 \\
\hline $\mathbf{F}$ & 5 & 0 & 0 & 0 & 0 & 0 & 12 & 2 & 3 & 710 \\
\hline$E$ & 66 & 0 & 0 & 0 & 1 & 2 & 0 & 0 & 0 & 3 \\
\hline D & 2 & 0 & 0 & 0 & 0 & 0 & 0 & 2 & 1 & 25 \\
\hline C & 2 & 0 & 0 & 0 & 0 & 0 & 0 & 7 & 1 & 2 \\
\hline B & 24 & 0 & 0 & 0 & 3 & 0 & 0 & 1 & 0 & 7 \\
\hline A & 4 & 15 & 0 & 0 & 0 & 0 & 0 & 0 & 0 & $\underline{0}$ \\
\hline
\end{tabular}


A teljes (a) és korrigált (b) mérési idő felhasználásával kiszámított $K_{S}$ értékek térbeli változatossága Csólyospáloson

(a)

\begin{tabular}{|c|c|c|c|c|c|c|c|c|c|c|}
\hline $\begin{array}{c}\mathrm{K}_{\mathrm{s}} \\
{[\mathrm{cm} / \mathrm{nap}]}\end{array}$ & 1 & 2 & 3 & 4 & 5 & 6 & 7 & 8 & 9 & 10 \\
\hline $\mathbf{J}$ & 64,2 & 26,0 & 19,8 & 7,2 & 15,7 & 69,6 & 75,9 & 53,4 & 75,4 & 80,4 \\
\hline I & 96,1 & 55,7 & 38,2 & 20,7 & 14,8 & 43,5 & 83,5 & 44,4 & 46,7 & 52,5 \\
\hline H & 66,4 & 84,9 & 78,1 & 112,2 & 3,1 & 63,8 & 44,4 & 61,1 & 31,4 & 53,0 \\
\hline G & 45,3 & 11,7 & 44,4 & 61,5 & 103,3 & 81,7 & 35,5 & 15,7 & 83,5 & 68,7 \\
\hline$F$ & 20,2 & 22,4 & 90,7 & 47,6 & 63,8 & 24,2 & 66,4 & 11,7 & 44,4 & 47,6 \\
\hline E & 51,2 & 5,8 & 19,8 & 23,8 & 36,8 & 3,1 & 38,6 & 28,3 & 43,1 & 36,4 \\
\hline D & 29,2 & 27,8 & 41,3 & 29,2 & 57,9 & 15,7 & 4,5 & 36,4 & 40,0 & 22,0 \\
\hline C & 78,6 & 77,2 & 75,4 & 76,8 & 88,0 & 84,4 & 77,7 & 32,8 & 4,0 & 17,1 \\
\hline B & 3,1 & 55,7 & 31,0 & 22,0 & 34,6 & 31,0 & 41,3 & 25,1 & 18,4 & 22,9 \\
\hline A & 66,0 & 53,9 & 37,3 & 26,5 & 16,2 & 105,5 & 124,4 & 40,4 & 32,3 & 44,0 \\
\hline
\end{tabular}

(b)

\begin{tabular}{|c|c|c|c|c|c|c|c|c|c|c|}
\hline $\begin{array}{c}\mathrm{K}_{\mathrm{s}} \\
{[\mathrm{cm} / \mathrm{nap}]}\end{array}$ & 1 & 2 & 3 & 4 & 5 & 6 & 7 & 8 & 9 & 10 \\
\hline $\mathbf{J}$ & 60,6 & 25,1 & 23,3 & 9,0 & 13,0 & 73,2 & 74,5 & 51,6 & 75,9 & 77,7 \\
\hline I & 94,3 & 57,5 & 45,3 & 29,2 & 15,7 & 43,1 & 87,5 & 62,4 & 52,5 & 48,9 \\
\hline H & 65,1 & 82,6 & 78,6 & 98,8 & 9,4 & 60,2 & 41,8 & 56,6 & 31,4 & 53,0 \\
\hline G & 50,7 & 12,1 & 46,2 & 63,3 & 98,3 & 76,3 & 31,4 & 20,7 & 78,1 & 72,3 \\
\hline$F$ & 21,1 & 18,4 & 90,2 & 52,1 & 61,1 & 25,6 & 65,5 & 10,3 & 42,2 & 47,6 \\
\hline$E$ & 53,4 & 9,4 & 26,5 & 25,1 & 37,7 & 17,1 & 43,5 & 30,1 & 45,8 & 37,3 \\
\hline D & 31,4 & 32,8 & 42,2 & 29,2 & 56,6 & 18,0 & 7,6 & 37,7 & 48,0 & 26,0 \\
\hline C & 31,4 & 73,6 & 83,1 & 72,3 & 70,0 & 68,7 & 73,6 & 37,7 & 8,1 & 18,4 \\
\hline B & 31,0 & 53,4 & 28,7 & 27,4 & 36,4 & 36,4 & 40,4 & 27,4 & 32,3 & 24,2 \\
\hline A & 59,3 & 49,8 & 35,5 & 43,1 & 26,5 & 97,9 & 124,4 & 40,4 & 32,3 & 44,0 \\
\hline$<5$ & & 5 & & & j-50 & & - 100 & & $>10$ & \\
\hline
\end{tabular}


A teljes mérési idő felhasználásával kiszámított $K_{S}$ értékek térbeli változatossága Örbottyánban

\begin{tabular}{|c|c|c|c|c|c|c|c|c|c|c|}
\hline $\begin{array}{l}\text { Ks } \\
\text { [cm/nap] }\end{array}$ & 1 & 2 & 3 & 4 & 5 & 6 & 7 & 8 & 9 & 10 \\
\hline $\mathbf{J}$ & 117,8 & 177,0 & 119,3 & 157,3 & 132,0 & 144,6 & 90,9 & 90,1 & 83,8 & 66 , \\
\hline I & 118,6 & 154,9 & 152,5 & 150,2 & 147,0 & 148,6 & 129,6 & 119,3 & 148,6 & 99,6 \\
\hline H & 102,0 & 155,7 & 154,9 & 148,6 & 193,6 & 158,9 & 135,9 & 187,3 & 138,3 & 154,8 \\
\hline G & 114,6 & 127,2 & 202,3 & 235,5 & 206,3 & 200,0 & 150,2 & 160,4 & 136,7 & 176,3 \\
\hline$F$ & 117,8 & 141,5 & 170,7 & 151,0 & 217,3 & 215,8 & 151,0 & 116,2 & 132,0 & 112, \\
\hline E & 83,8 & 136,7 & 175,5 & 162,8 & 175,5 & 155,7 & 143,1 & 128,8 & 132,8 & 142,3 \\
\hline D & 93,3 & 118,6 & 148,6 & 184,9 & 164,4 & 165,2 & 146,2 & 60,9 & 118,6 & 76,7 \\
\hline C & 90,1 & 153,3 & 124,1 & 135,2 & 113,0 & 192,1 & 106,7 & 79,0 & 75,1 & 100, \\
\hline B & 106,7 & 140,7 & 160,4 & 187,3 & 97,2 & 156,5 & 105,9 & 107,5 & 96,4 & 71. \\
\hline A & 83,8 & 56,1 & 171,5 & 211,0 & 202,3 & 169,1 & 118,6 & 124,9 & 94,8 & 106,7 \\
\hline
\end{tabular}

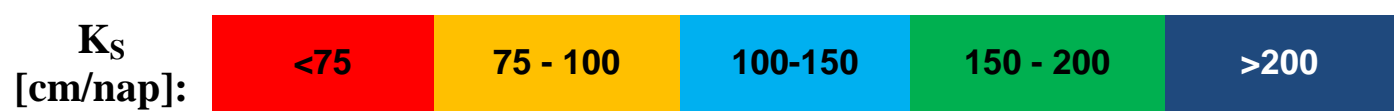


Mért és cm-es, illetve dm-es felbontású szimulált talajnedvesség értékek összehasonlítása 0-10 cm-es mélységben, Őrbottyánban

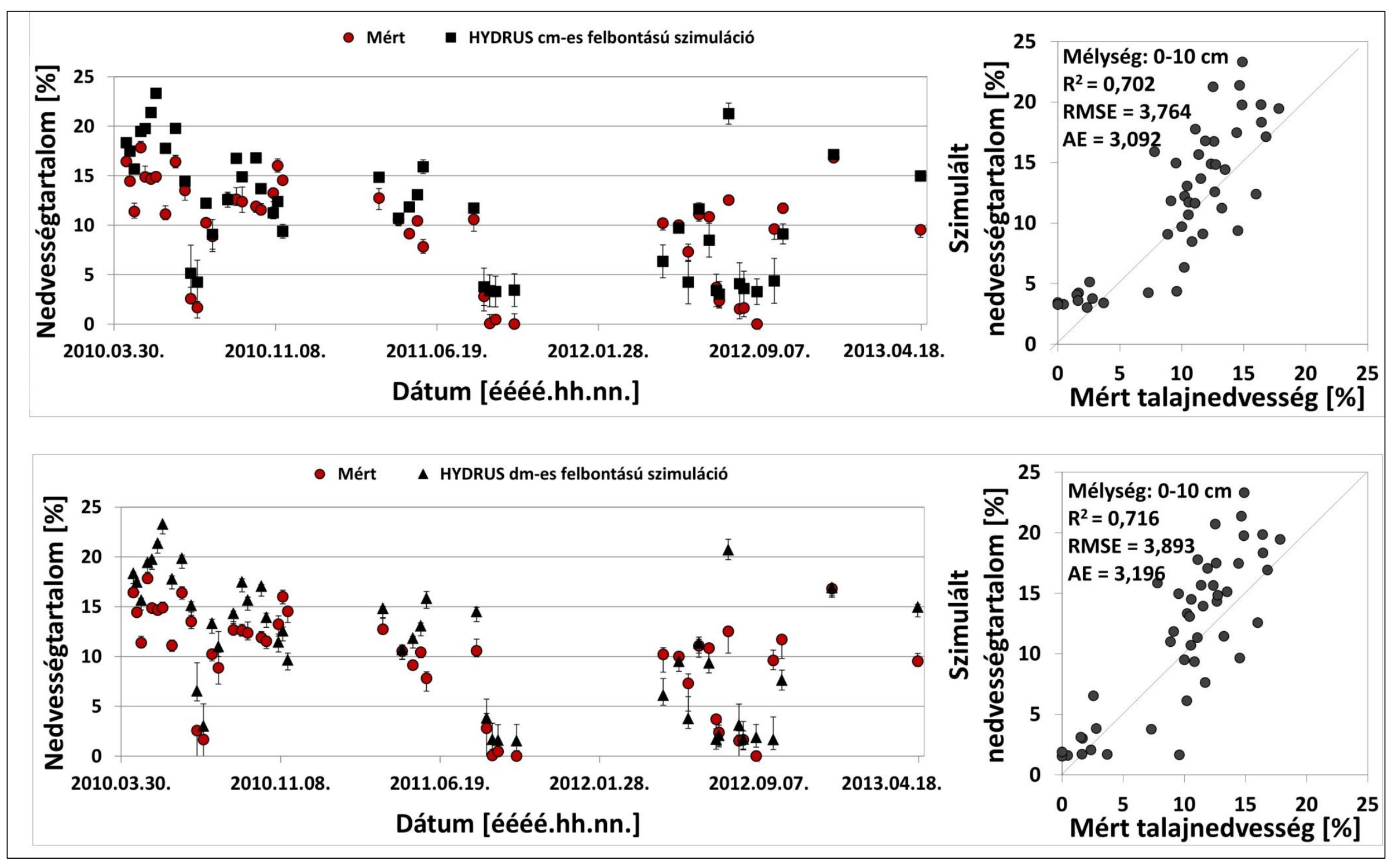


Mért és cm-es, illetve dm-es felbontású szimulált talajnedvesség értékek összehasonlítása 0-80 cm-es mélységben, Őrbottyánban
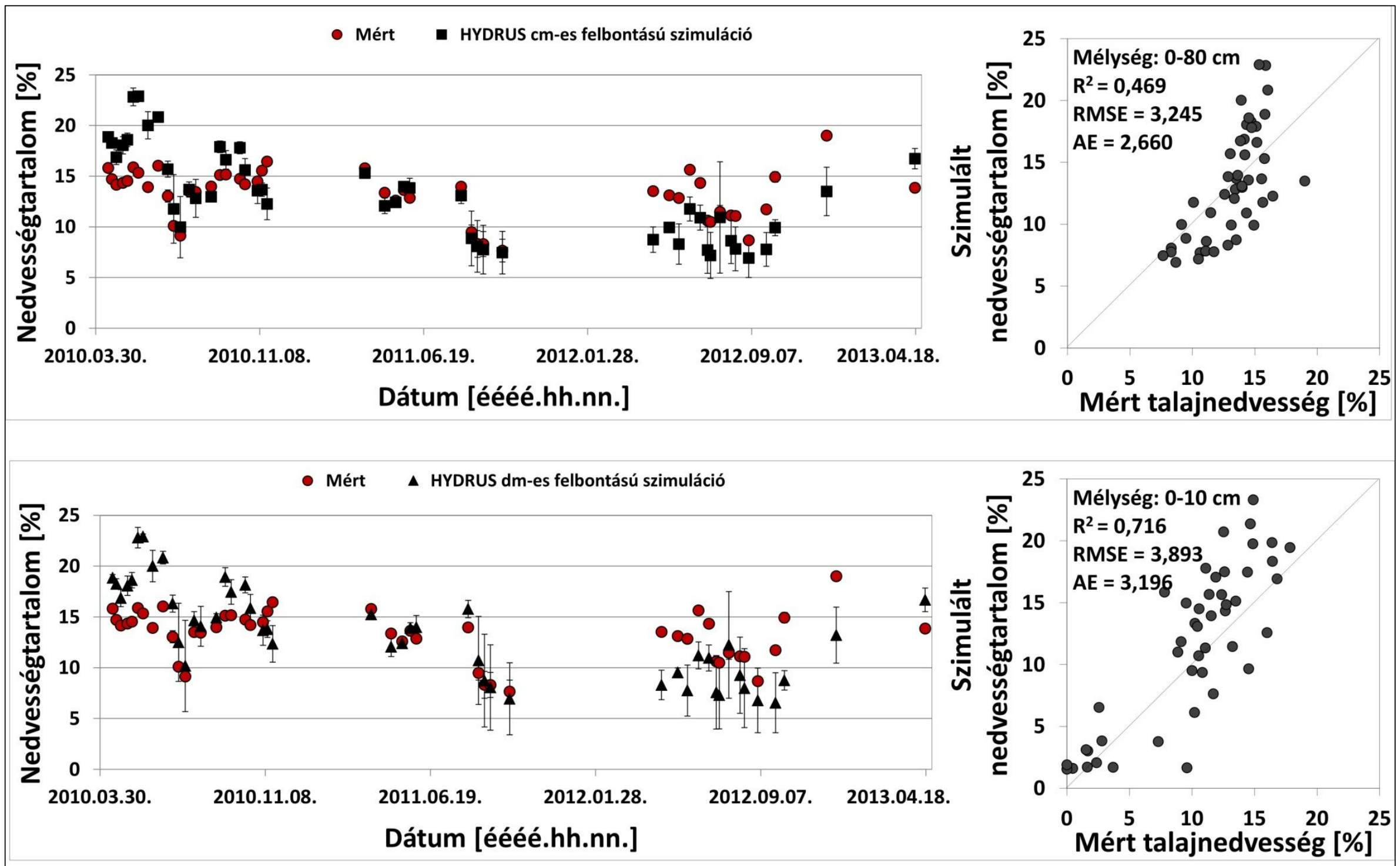